\title{
Hydrology and Water Quality of Lakes and Streams in Orange County, Florida
}

By Edward R. German and James C. Adamski

Prepared in cooperation with the

CITY OFORLANDO

ORANGE COUNTY PUBLIC UTILITIES

ORLANDO UTILITIES COMMISSION

REEDY CREEK IMPROVEMENT DISTRICT

ST. JOHNS RIVER WATER MANAGEMENT DISTRICT

SOUTH FLORIDA WATER MANAGEMENT DISTRICT

Scientific Investigations Report 2005-5052 


\section{U.S. Department of the Interior \\ Gale A. Norton, Secretary}

\section{U.S. Geological Survey \\ P. Patrick Leahy, Acting Director}

\section{U.S. Geological Survey, Reston, Virginia: 2005}

For sale by U.S. Geological Survey, Information Services

Box 25286, Denver Federal Center

Denver, CO 80225

For more information about the USGS and its products:

Telephone: 1-888-ASK-USGS

World Wide Web: http://www.usgs.gov/

Any use of trade, product, or firm names in this publication is for descriptive purposes only and does not imply endorsement by the U.S. Government.

Although this report is in the public domain, permission must be secured from the individual copyright owners to reproduce any copyrighted materials contained within this report.

Suggested Citation: German, E.R., and Adamski, J.C., 2005, Hydrology and Water Quality of Lakes and Streams in Orange County, Florida: U.S. Geological Scientific Investigations Report 2005-5052, 103 p. 


\section{Contents}

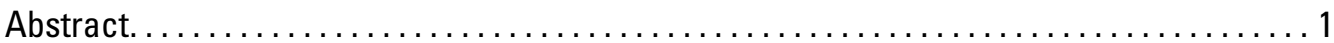

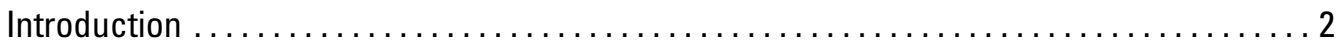

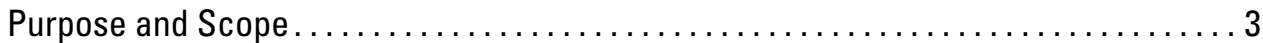

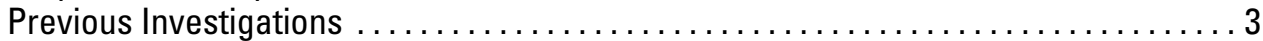

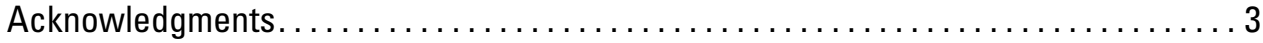

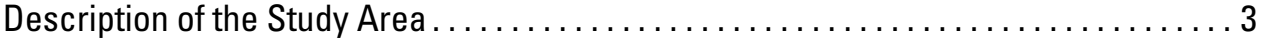

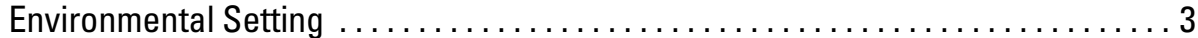

Surface Drainage ....................................... 7

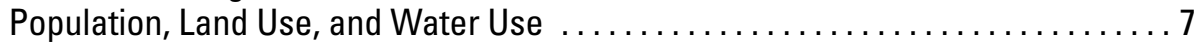

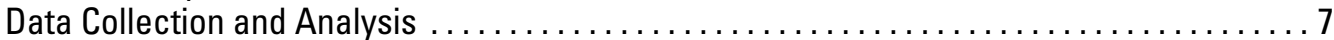

Precipitation, Streamflow, and Lake Levels ........................... 7

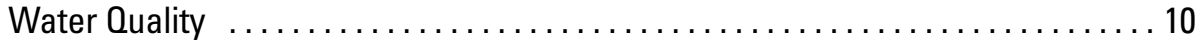

Hydrology ................................................ 20

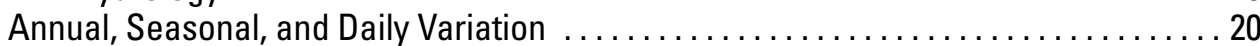

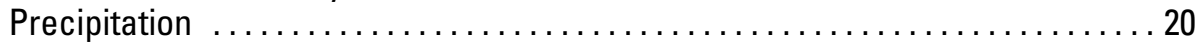

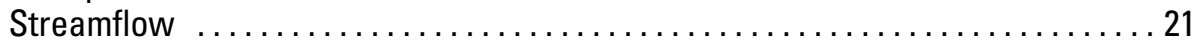

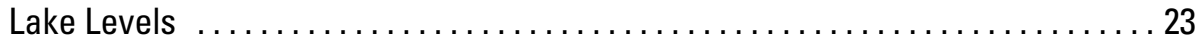

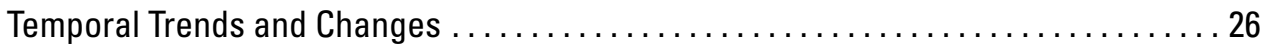

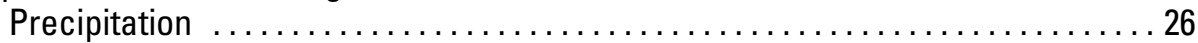

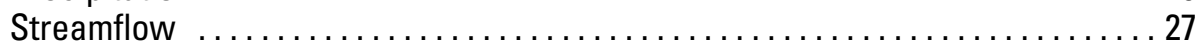

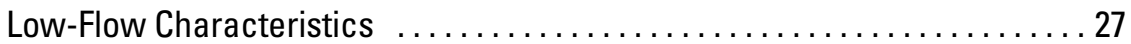

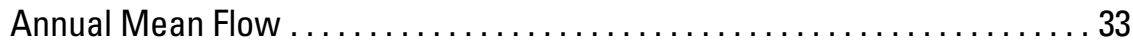

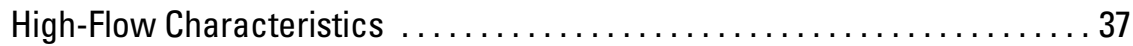

Lake Water Levels .......................................... 37

Streamflow Duration and Recurrence Intervals . . . . . . . . . . . . . . . . . 50

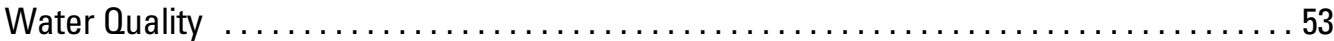

Major lons and Nutrients in Streams . . . . . . . . . . . . . . . . . . . . . 53

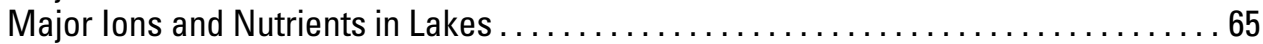

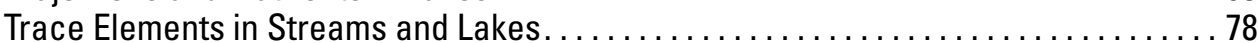

Pesticides in Streams and Lakes ................................. 79

Household and Industrial Waste Compounds in Streams and Lakes ............ 81

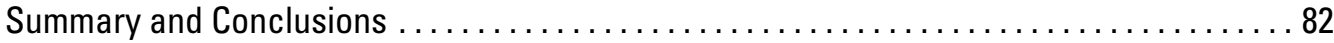

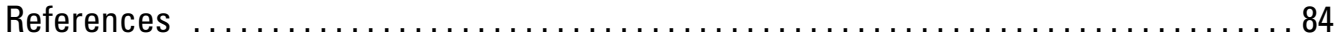

Appendixes:

A. Annual rainfall totals for selected National Oceanographic Atmospheric

Administration stations. . . . . . . . . . . . . . . . . . . . . . . . . . . . . . . . 88-89

B. Summary of water-level measurements for selected lakes. . . . . . . . . . . 90 90-92

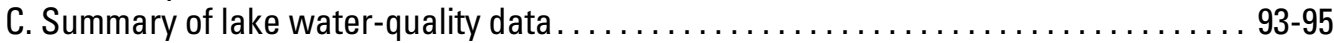

D. Field measurements and concentrations of major ions, nutrients, and trace elements in samples collected from lakes during this study, 2000-2001 . . . . . . . 96-99

E. Concentrations of pesticides in samples collected from lakes and streams during

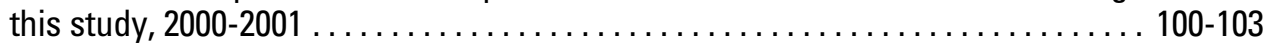




\section{FIGURES}

1-4. Maps showing:

1. Major cities and drainage basins in Orange County, Florida . . . . . . . . . . . . 4

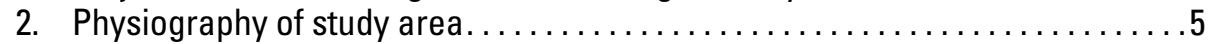

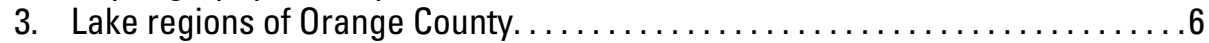

4. Generalized land use in Orange County in 1997, showing expansion of

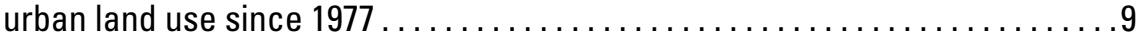

5. Chart showing summary of water use in Orange County, 1965-2000 ...........10

6-9. Maps showing:

6. Location of selected National Oceanic Atmospheric Administration rainfall stations in central Florida...

7. Location of U.S. Geological Survey streamflow and water-quality stations in and near Orange County . .........................

8. Location of lakes with four or more water-level measurements each year for more than 15 years. ................................. 13

9. Location of lakes with water-quality data in and around Orange County ... . 16

10. Chart showing monthly and seasonal variation in rainfall at Orlando, 1931-2000 . . 20

11. Graph showing distribution of daily rainfall at Orlando according to percent of total accumulation and to percent of days with less rainfall, $1949-98 \ldots \ldots \ldots \ldots 21$

12. Hydrographs showing duration of daily discharge for selected streams in central Florida

13-17. Graphs showing:

13. Stage-duration for selected lakes in and around Orange County . . . . . . 26-27

14. Maximum, median, and minimum water levels by month for Lake

Sherwood and Lake Silver. .

15. Annual rainfall and 5-year moving average of annual rainfall at

Orlando, 1931-2000

16. Seven-day low flow for selected streams in or near Orange County ...... 31-32

17. Annual mean streamflow for selected streams in or near Orange County . 35-36

18. Double-mass plots showing streamflow for selected streams in or near Orange County

19. Graphs showing one-day high flow for selected streams in or near

Orange County..

20. Hydrographs showing lakes with a significant downward trend in water level

21. Hydrographs showing lakes with a significant upward trend in water level. . . . 47-49

22. Map showing lakes with trends in mean-annual water level for 1970-97 . . ......51

23. Charts showing distribution of specific conductance, $\mathrm{pH}$, and concentrations of bicarbonate and sulfate in historical samples for selected streams, 1960-2001. . . .58

24. Charts showing distribution of chloride, nitrite plus nitrate, ammonia plus organic nitrogen, and total phosphorus in historical samples for selected streams, 1960-2001

25-29. Graphs showing:

25. Relation of specific conductance to streamflow for historical samples from the Econlockhatchee River and Boggy Creek, 1960-2001

26. Relation of specific conductance to time in samples for the Econlockhatchee River and Boggy, Bonnet, and Whittenhorse Creeks ...

27. Relation of bicarbonate concentrations to time in samples for the Econlockhatchee River and Boggy and Bonnet Creeks

28. Relation of sulfate concentrations to time in samples for Boggy Creek, and relation of chloride concentrations to time in samples from Boggy, Bonnet, and Whittenhorse Creeks. .

29. Relation of nitrite plus nitrate and ammonia plus organic nitrogen concentrations to time in samples for the Econlockhatchee River, and relation of total phosphorus concentrations to time in samples for the Econlockhatchee River and Boggy Creek... 
30. Charts showing distribution of specific conductance, and concentrations of bicarbonate, sulfate, chloride, nitrite plus nitrate, ammonia plus organic nitrogen, and total phosphorus in historical samples from Reedy Creek ........66 66

31. Charts showing comparison of lake water quality by lake region $\ldots \ldots \ldots \ldots \ldots 6$ 32-36. Maps showing:

32. Specific conductance for selected lakes in Orange County, 2000-01 . . . . . 70

33. Concentrations of major cations and anions for selected lakes in Orange

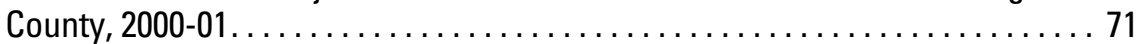

34. Total nitrogen concentrations for selected lakes in Orange County,

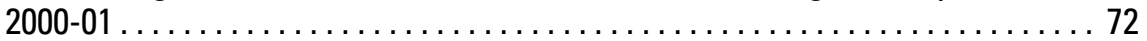

35. Chlorophyll-a concentrations for selected lakes in Orange County,

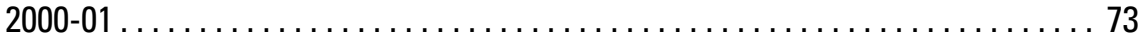

36. Trophic state indexes for selected lakes in Orange County, 2000-01... . . . 74

37. Graphs showing relation of water clarity (secchi disk readings) with chlorophyll-a concentrations, and relation of chlorophyll-a concentrations to total phosphorus concentrations

38. Graphs showing temporal variations of water clarity (secchi disk readings), total phosphorus and chlorophyll-a concentrations, and trophic state

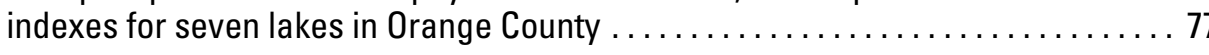

\section{TABLES}

1. Characteristics of major drainage basins in Orange County, Florida .......... 8

2. Stream sites with streamflow and water-quality data collected by the

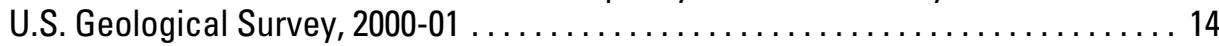

3. Lakes sampled by the U.S. Geological Survey, 2000-01 ................. 15

4. Pesticide and pesticide metabolite compounds sampled, $2000-01 \ldots \ldots \ldots \ldots 17$

5. Compounds associated with wastewater sampled, $2000-01 \ldots \ldots \ldots \ldots \ldots 18-19$

6. Period of record and streamflow statistics for stations in Orange County

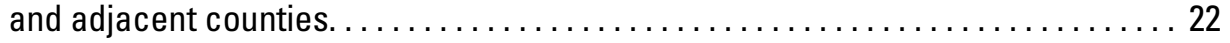

7. Temporal trends in annual rainfall totals at sites in the vicinity of

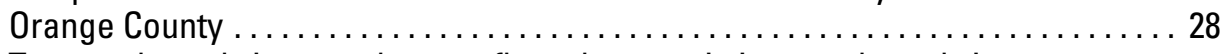

8. Temporal trends in annual streamflow characteristics at selected sites

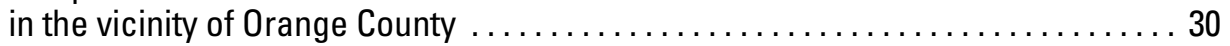

9. Summary of regression models for estimating annual mean streamflow

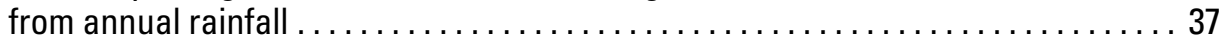

10. Results of statistical testing for trends in lake water levels . ............ $42-43$

11. Flow-duration characteristics for selected streams in Orange County

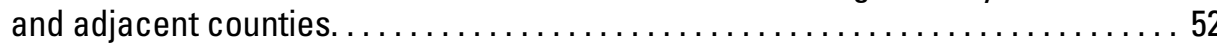

12. Low and high-flow frequency statistics for selected streams in and near

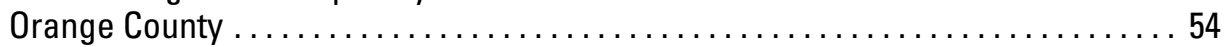

13. Summary statistics of water-quality indicators and chemical constituents

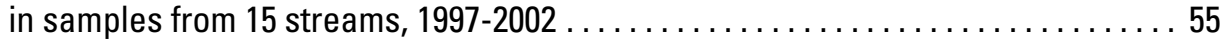

14. Stream sites with historical water-quality data, periods of record, basin

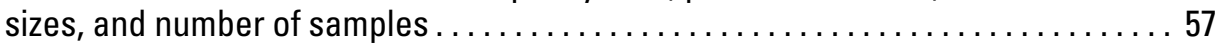

15. Relation between water-quality properties or constituents and streamflow at selected streams in Orange County .................... 60

16. Temporal trends in water quality at selected sites in Orange County ..........63

17. Summary statistics of water-quality indicators and chemical constituents in samples from 140 lakes in Orange County, 2000-01 .................. 69

18. Comparison of water quality of Reedy Lake with range of water quality of reclaimed water........................................... 76

19. Summary statistics of trace-element concentrations in samples from

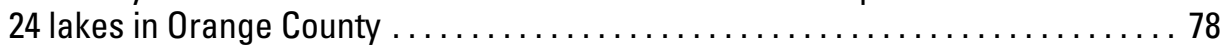

20. Summary statistics of trace-element concentrations in samples from 15 streams in Orange County. 
21. Stream sites, date of sample collection, and number of pesticide compounds detected in each sample............................. 80

22. Lake site, date of sample collection, and number of pesticide compounds detected in each sample............................ 80

23. Pesticide compounds, number of detections, and range of concentrations in samples from lakes and streams in Orange County, 2000-01 . . . . . . . . . . 81

24. Selected results of analysis of surface-water samples for household and industrial wastes compounds. ...

\section{Conversion Factors, Vertical Datum, Acronyms, and Abbreviations}

\begin{tabular}{rll}
\hline Multiply & By & To obtain \\
\hline & Length & \\
inch (in.) & 2.54 & centimeter \\
foot (ft) & 0.3048 & meter \\
mile (mi) & 1.609 & kilometer \\
& Area & \\
square mile ( $\left.\mathrm{mi}^{2}\right)$ & 2.590 & square kilometer \\
& Flow Rate & \\
& 0.02832 & cubic meter per second \\
cubic foot per second (ft $/ \mathrm{s})$ & 0.04381 & cubic meter per second \\
million gallons per day (Mgal/d) & 25.4 & millimeter per year \\
inch per year (in/yr)
\end{tabular}

*The standard unit for transmissivity is cubic foot per day per square foot times foot of aquifer thickness $\left[\left(\mathrm{ft}^{3} / \mathrm{d}\right) / \mathrm{ft}^{2}\right] \mathrm{ft}$. In this report, the mathematically reduced form, foot squared per day $\left(\mathrm{ft}^{2} / \mathrm{d}\right)$, is used for convenience.

Temperature in degrees Fahrenheit $\left({ }^{\circ} \mathrm{F}\right)$ may be converted to degrees Celsius $\left({ }^{\circ} \mathrm{C}\right)$ as ${ }^{\circ} \mathrm{C}=\left({ }^{\circ} \mathrm{F}-32\right) / 1.8$.

Vertical coordinate information is referenced to the National Geodetic Vertical Datum of 1929 (NGVD 29). Horizontal coordinate information (latitude-longitude) is referenced to the North American Datum of 1927 (NAD 27).

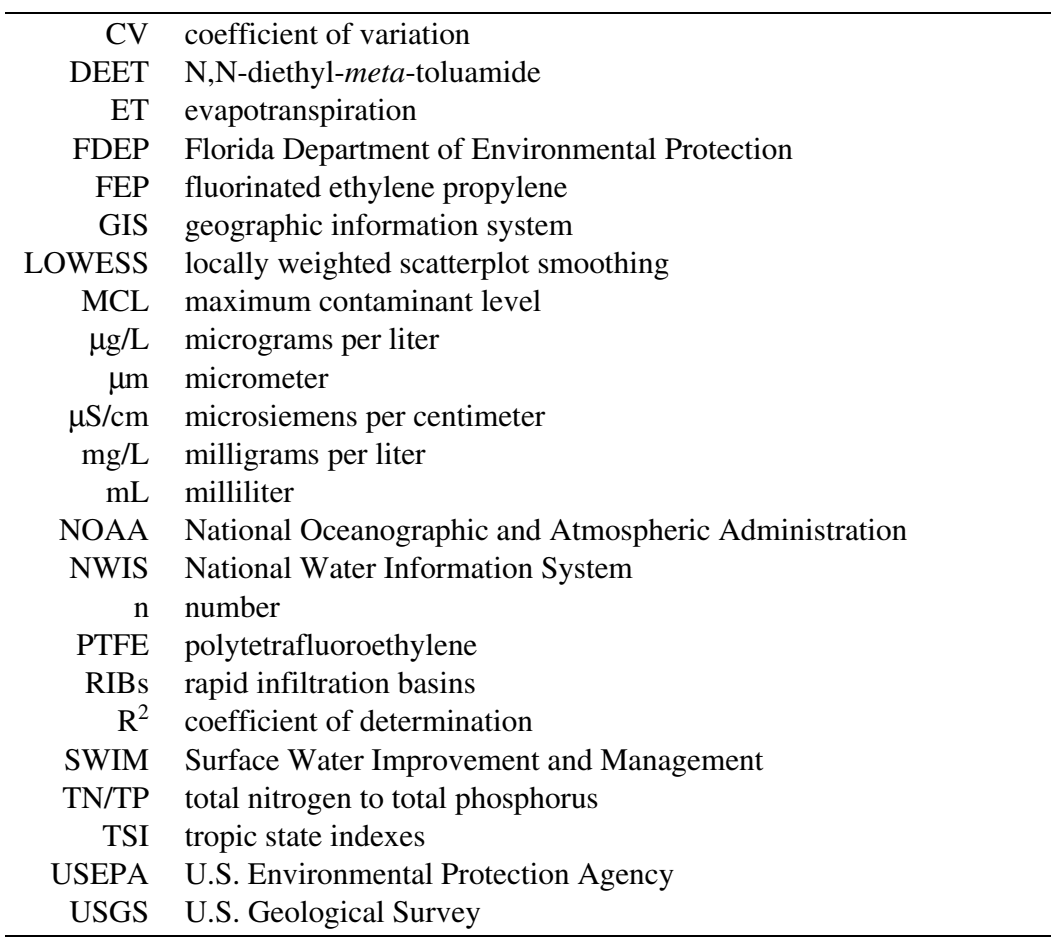




\title{
Hydrology and Water Quality of Lakes and Streams in Orange County, Florida
}

\author{
By Edward R. German and James C. Adamski
}

\begin{abstract}
Orange County, Florida, is continuing to experience a large growth in population. In 1920, the population of Orange County was less than 20,000; in 2000, the population was about 896,000 . The amount of urban area around Orlando has increased considerably, especially in the northwest part of the County. The eastern one-third of the County, however, had relatively little increase in urbanization from 1977-97. The increase of population, tourism, and industry in Orange County and nearby areas changed land use; land that was once agricultural has become urban, industrial, and major recreation areas. These changes could impact surface-water resources that are important for wildlife habitat, for esthetic reasons, and potentially for public supply. Streamflow characteristics and water quality could be affected in various ways.

As a result of changing land use, changes in the hydrology and water quality of Orange County's lakes and streams could occur. Median runoff in 10 selected Orange County streams ranges from about 20 inches per year (in/yr) in the Wekiva River to about $1.1 \mathrm{in} / \mathrm{yr}$ in Cypress Creek. The runoff for the Wekiva River is significantly higher than other river basins because of the relatively constant spring discharge that sustains streamflow, even during drought conditions. The low runoff for the Cypress Creek basin results from a lack of sustained inflow from ground water and a relatively large area of lakes within the drainage basin.

Streamflow characteristics for 13 stations were computed on an annual basis and examined for temporal trends. Results of the trend testing indicate changes in annual mean streamflow, 1-day high streamflow, or 7-day low streamflow at 8 of the 13 stations. However, changes in 7-day low streamflow are more common than changes in annual mean or 1-day high streamflow.
\end{abstract}

There is probably no single reason for the changes in 7-day low streamflows, and for most streams, it is difficult to determine definite reasons for the flow increases. Low flows in the Econlockhatchee River at Chuluota have increased because of discharge of treated wastewater since 1982. However, trends in increasing 7-day low streamflow are evident before 1982, which cannot be attributed to wastewater discharge.

Some of the increases in 7-day low flows may be related to drainage changes resulting from increased development in Orange County. Development for most purposes, including those as diverse as cattle grazing and residential construction, may involve modification of surface drainage through stream channelization and construction of canals. These changes in land drainage can lower the water table, resulting in reductions of regional evapotranspiration rates and increased streamflow. Another possible cause of increasing low flows in streams is use of water from the Floridan aquifer system for irrigation. Runoff of irrigation water or increased seepage from irrigated areas to streams could increase base streamflow compared to natural conditions.

Water-level data were analyzed to determine temporal trends from 83 lakes that had more than 15 years of record. There were significant temporal trends in 33 of the 83 lakes (40 percent) over the entire period of record. Of these 33 lakes, 14 had increasing water levels and 19 lakes had decreasing water levels. The downward trends in longterm lake levels could in part be due to high rainfall accumulation in 1960-1961, which included precipitation from Hurricane Donna (September 1960). The high rainfall resulted in historical high-water levels in many lakes in 1960 or 1961.

A large range of water-quality conditions exists in lakes and streams of Orange County (2000-01). Specific conductance in lake samples ranged from 57 to 1,185 


\section{Hydrology and Water Quality of Lakes and Streams in Orange County, Florida}

microsiemens per centimeter. Values of $\mathrm{pH}$ ranged from 3.2 to 8.7 in stream samples and 4.6 to 9.6 in lake samples. Total nitrogen concentrations ranged from less than 0.2 to 7.1 milligrams per liter $(\mathrm{mg} / \mathrm{L})$ as nitrogen in stream samples, and from less than 0.2 to $6.0 \mathrm{mg} / \mathrm{L}$ as nitrogen in lake samples. Concentrations of total nitrogen less than $1.0 \mathrm{mg} / \mathrm{L}$ as nitrogen are considered background levels. Concentrations of total nitrogen greater than about 1.6 to $2.0 \mathrm{mg} / \mathrm{L}$ as nitrogen probably are considered elevated and could indicate contamination from surface runoff. The most commonly detected trace elements in streams were aluminum, barium, boron, iron, manganese, and strontium.

Water-quality data from four sites (Econlockhatchee River, Boggy Creek, Bonnet Creek, and Whittenhorse Creek) had significant temporal trends in at least two of the seven constituents. Values of specific conductance and concentrations of chloride increased at the Boggy Creek, Bonnet Creek, and Whittenhorse Creek sites. Bicarbonate concentrations increased at the Econlockhatchee River, Boggy Creek, and Bonnet Creek sites. Sulfate concentrations increased at the Boggy Creek site. Concentrations of nitrite plus nitrate and ammonia plus organic nitrogen decreased at the Econlockhatchee River site. Phosphorus concentrations significantly decreased at the Econlockhatchee River and Boggy Creek sites. Many of these changes probably are related to changes in land use. However, decreased nitrogen and phosphorus concentrations in the Econlockhatchee River site near Chuluota are the result of constructing a waste-water treatment facility in 1982, providing secondary treatment of wastewater discharged into the river. This facility was upgraded to include nitrogen and phosphorus removal on the Little Econlockhatchee River, a tributary of the Econlockhatchee River.

Multiple sources probably contribute to the occurrence of pesticides that were detected in surface water. The most commonly detected pesticides were atrazine, prometon, simazine, tebuthiuron, and diazinon. Atrazine had the highest concentration ( 0.716 microgram/liter). Because the surface-water samples were collected during baseflow, runoff probably did not contribute to pesticide concentrations in streams. However, runoff to lakes during wet periods could have contributed pesticides, which can persist during dry conditions. Pesticide detections in samples from relatively pristine sites, such as the pond at Tosohatchee State Reserve, indicate that airborne sources could contribute pesticides to surface water in Orange County.

\section{Introduction}

Surface-water resources are important for wildlife habitat, for esthetic reasons, and potentially for potable supply. Over approximately the past 30 years, Orange County and surrounding counties have become a major tourist destination for people from all over the world, beginning with the opening of Walt Disney World in 1971. The increase of population, tourism, and industry in Orange County and nearby areas has altered land use, that is, land that was agricultural has become urban, industrial, and major recreation areas. These changes have the potential to affect streamflow characteristics and water quality in various ways.

There have been major changes in wastewater treatment methods over approximately the past 30 years that have a bearing on water quality. Beginning in 1972, Federal Water Pollution Control Act Amendments, commonly referred to as the Clean Water Act, has provided federal funding to local governments for upgrading wastewater treatment systems. The overall pattern of change has been for numerous small treatment plants to consolidate into large regional treatment centers that provide a greater degree of wastewater treatment than the smaller plants that were replaced. Also, there has been a reduction or complete removal of wastewater discharge to streams (including Reedy Creek, Shingle Creek, Little Econlockhatchee River, and Little Wekiva River) since the late 1980s.

The last comprehensive hydrologic investigation of Orange County was conducted by Lichtler and others (1968) of the U.S. Geological Survey (USGS). Since that time, the USGS and other State and local agencies have collected more hydrologic information about the surfaceand ground-water resources of Orange County and surrounding areas. To provide a compilation and interpretation of the additional data, the USGS in cooperation with the City of Orlando, the Orange County Public Utilities, the Orlando Utilities Commission, the Reedy Creek Improvement District, the South Florida Water Management District, and the St. Johns River Water Management District began a 4-year study in 1998. The principal objective of this study is to provide an assessment of surfacewater conditions in Orange County including basin hydrology, streamflow statistics, lake levels, and water quality. The data and findings of the study will be useful to the public and to officials who are responsible for planning, developing, and managing the water resources of Orange County and the east-central Florida region. 


\section{Purpose and Scope}

This report documents hydrologic and water-quality conditions in selected streams and lakes of Orange County, Florida. This report summarizes rainfall data from 1932-2000 at nine stations operated by the National Oceanographic and Atmospheric Administration (NOAA). Daily records for 13 USGS streamflow stations were reviewed to summarize low, mean, and high streamflow conditions during 1934-2000. Low- and high-frequency statistics and duration curves were computed. Periodic lake-level measurements by the USGS and Orange County at 83 lakes during 1933-1998, historical water-quality data collected by the USGS and the Orange County Environmental Protection Division during 19602000, and water quality data from 24 lakes and 11 stream sites collected by the USGS and Orange County during 1999-2001 are presented. Trends in lakes levels, streamflow, and water quality are identified and discussed. Areal patterns in water quality are examined; the effect of land use on selected hydrologic characteristics is discussed. This report is one of two reports summarizing the water resources of Orange County. Ground-water data and interpretations are presented in Adamski and German (2003).

\section{Previous Investigations}

The USGS has conducted surface-water resource studies in Orange County for more than 30 years. Anderson and Joyner (1966) described the availability and quality of surface water. Lichtler and others (1968) reported on both ground- and surface-water conditions in Orange County. Lichtler and others (1976) investigated the hydrologic connection between ground water and three lakes in the Orlando area. Phelps and German (1995), Smoot and Schiffer (1985), German (1983), Gaggiani and Lamonds (1977), and Pfischner (1968) described the hydrology and quality of water in selected Orange County lakes. Schiffer (1989) described the effects of urban runoff on the water quality of wetlands in the metropolitan Orlando area.

Rumenik and Grubbs (1996) reported statistics on lowflow characteristics of streams using data from the beginning of record through September 1987.

State and local government agencies, consultants, and universities also have completed numerous studies and reports. The following list is not comprehensive, but includes studies with information or data related to surface water in Orange County. Water quality and nonpoint loading in the Little Econlockhatchee Drainage basin are discussed in Harper and Herr (1966). Water quality, quantity, and suggested restoration measures for the Little
Econlockhatchee River are discussed in Miller \& Miller (1984). O'Dell (1994) discussed water quality in the Shingle Creek Basin before and after wastewater diversion. McCann and others (1998) described water quality of lakes in and around Orlando. The Little Wekiva River basin history is described in Woodward-Clyde Consultants (1998). Lake chemistry and water quality in Florida and Orange County were studied by Brezonik (1984), who developed a tropic-state classification system for Florida lakes. Other lake water-quality reports are available on the web page of the City of Orlando (2004).

\section{Acknowledgments}

The authors express their appreciation to public officials of Orange County, the City of Orlando, and the Orlando Utilities Commission, whose cooperation and knowledge greatly aided this investigation. The authors are particularly grateful for land-use, lake-level, and water-quality data provided by the City of Orlando Stormwater Utility Bureau, Orange County Environmental Protection Division, Orange County Planning Division, and Reedy Creek Improvement District. The authors also are grateful for access to land owned by the City of Orlando, Orange County, the State of Florida, and private land owners.

\section{Description of the Study Area}

Orange County, in the east-central part of the Florida peninsula (fig. 1), encompasses about 1,003 square miles $\left(\mathrm{mi}^{2}\right) ; 916 \mathrm{mi}^{2}$ are land and the remainder is surface-water bodies. Orlando and surrounding communities (including Winter Park, Altamonte Springs, and others) are the major population centers in the County. Since 1971, the southcentral part of Orange County has become a major recreational area with several large theme parks, hotel complexes, and golf courses that attract hundreds of thousands of tourists each year.

\section{Environmental Setting}

Orange County has a humid subtropical climate with relatively short, mild winters, and long, hot summers. The normal average annual temperature at Orlando is 72.3 degrees Fahrenheit $\left({ }^{\circ} \mathrm{F}\right)$ and the normal average annual rainfall is about 49.9 inches (National Oceanic and Atmospheric Administration, 2001). More than one-half of the annual rainfall total generally occurs during June through September, commonly referred to as the wet season. 


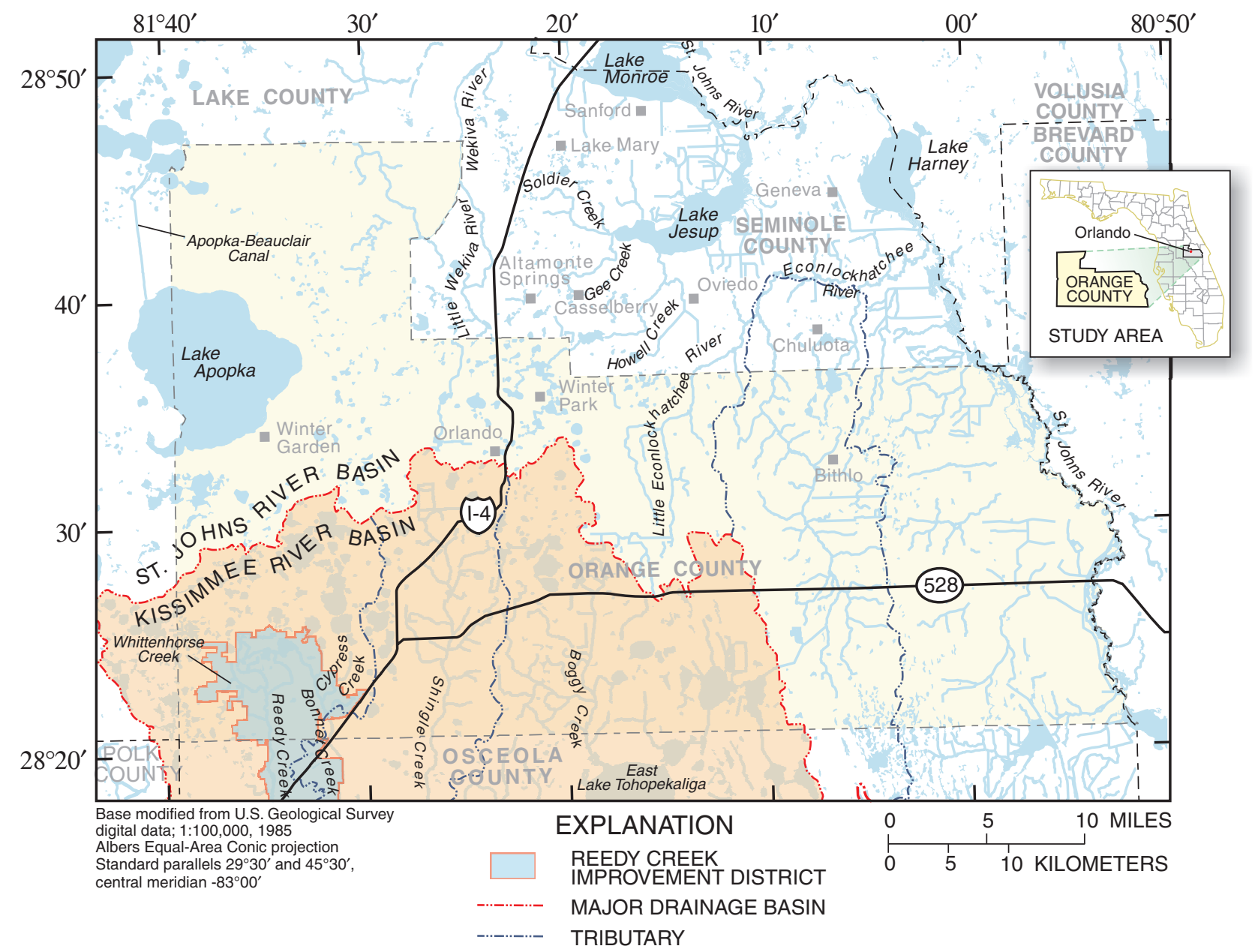

Figure 1. Major cities and drainage basins in Orange County, Florida.

Three major hydrogeologic units are present in Orange County: the surficial aquifer, the intermediate confining unit, and the Upper Floridan aquifer. The uppermost surficial sediments consist mostly of quartz sand with varying amounts of clay and shell. The thickness of these sediments generally is about 40 feet $(\mathrm{ft})$ but is greater in highland areas. These surficial sediments comprise the surficial aquifer system. Beneath the surficial sediments are sediments of Miocene to post-Miocene age that include the Hawthorn Group. The Hawthorn Group sediments include noncontinuous clayey sands and clay layers that in some areas retard the downward seepage of water from the surficial aquifer system. The thickness of this intermediate confining unit is variable; the unit is absent at some locations and as thick as $200 \mathrm{ft}$ at other locations. Underlying the intermediate confining unit are the limestones of the Upper Floridan aquifer. The surface of the Upper Floridan aquifer has been modified by erosion; consequently the altitude of the top of the aquifer varies widely. Sinkholes, caused by dissolution of limestone combined with the gradual subsurface movement of unconsolidated sediments into these solution cavities, are common-particularly in higher, well-drained parts of the County. Most of the lakes in Orange County are of sinkhole origin.

Orange County lies in the Atlantic Coastal Plain described by Meinzer (1923, pl. 28). The County contains three topographic regions: (1) low-land regions where altitudes generally are less than $35 \mathrm{ft}$; (2) intermediate regions where altitudes are between 35 and $105 \mathrm{ft}$; and (3) highland regions where altitudes generally are above $105 \mathrm{ft}$. There are eight physiographic provinces within Orange County: the Central Valley, the Eastern Valley, the Lake Wales Ridge, the Marion Upland, the Mount Dora Ridge, the Orlando Ridge, the Osceola Plain, and the Wekiva Plain (White, 1958) (fig. 2). More detailed topographic descriptions of Orange County are given in Puri and Vernon (1964) and in Lichtler and others (1968). 


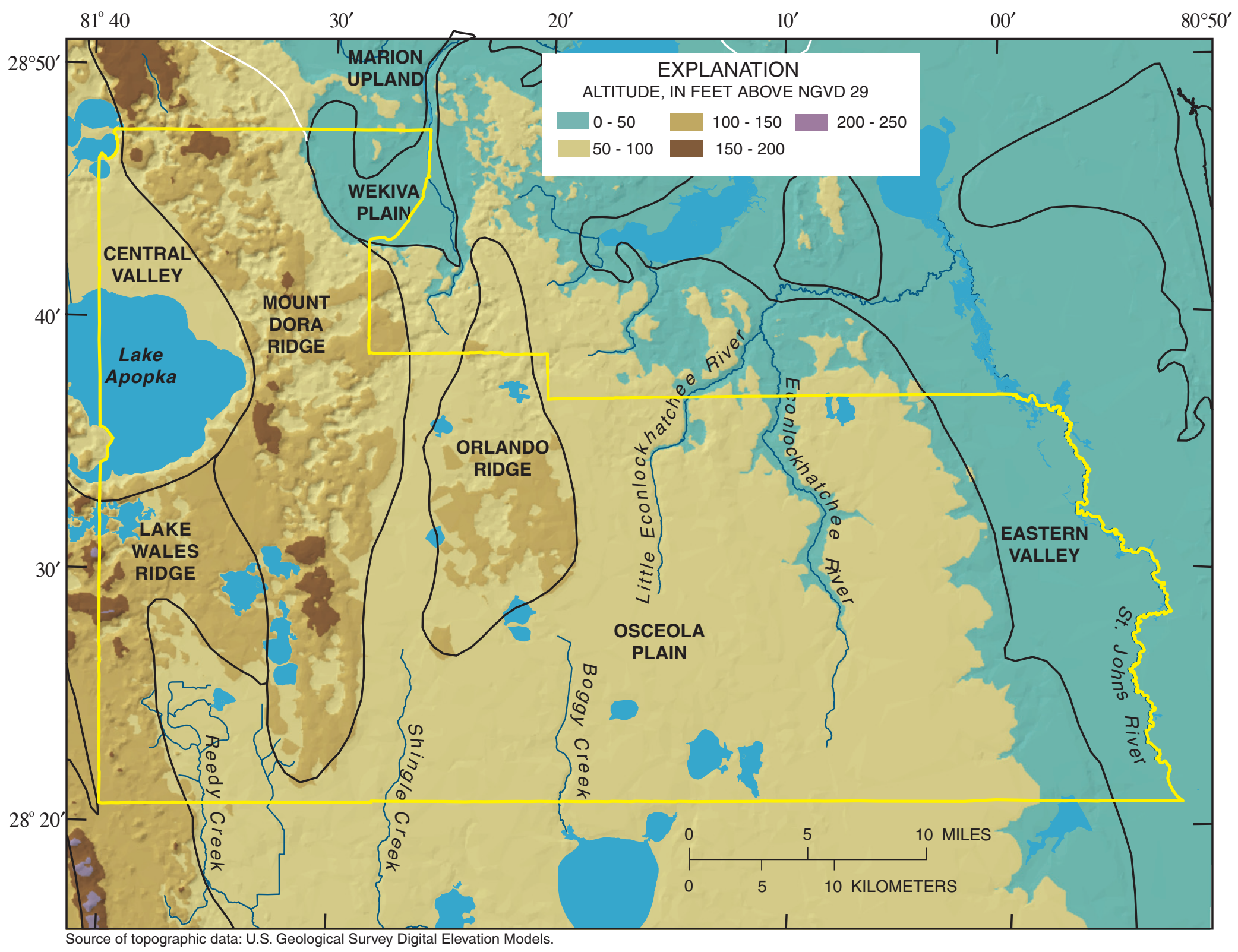

Figure 2. Physiography of study area (modified from White, 1970). 


\section{Hydrology and Water Quality of Lakes and Streams in Orange County, Florida}

The three topographic regions have different characteristics and extent of development. The lowland region includes the St. Johns River marsh, the northern part of the Econlockhatchee River basin, and areas in the northeast part of the County. These lowlands are within the Eastern Valley, the Wekiva Plain, and the Osceola Plain physiographic provinces (fig. 2). Most of the lakes (but not all) in the lowlands are part of the St. Johns River system. The lowlands are relatively unsuited for development because of a perennially high-water table that can be above the landsurface elevation during wet periods. Extensive drainage generally is required for any sort of development. The intermediate region occupies most of the middle part of the County between the lowlands to the east and the highlands to the west, and generally coincides with the Osceola Plain and the Central Valley provinces. This intermediate area is extensively developed in some places, and includes parts of the Orlando metropolitan area. The highlands lie within parts of the Orlando Ridge, the Mount Dora Ridge, and the Lake Wales Ridge in central and west Orange County

(fig. 2). These highlands, which contain numerous internally drained lakes and depressions, are areas of effective recharge to the Floridan aquifer system and, thus, are important to Orange County's water supply. The highlands also are excellent for citrus cultivation and urban development. Prior to the severe freezes of 1983, 1985, and 1989, much of the highland areas were used for citrus cultivation. After the freezes, much of the land used to grow citrus trees was converted to urban and residential areas.

Lakes in Orange County can be classified using the lake region classification system of the U.S. Environmental Protection Agency. This system is useful in summarizing and comparing lake water-quality data, and is based primarily on physiography, soils, geology, natural vegetation, and land use and cover. In defining the lake regions, the goal was to "define a reasonable number of lake regions that appear to have some meaningful differences between them" (Griffith and others, 1997, p. 7). For Florida, 47 lake regions have been defined. Orange County includes all or parts of seven lake regions (fig. 3).

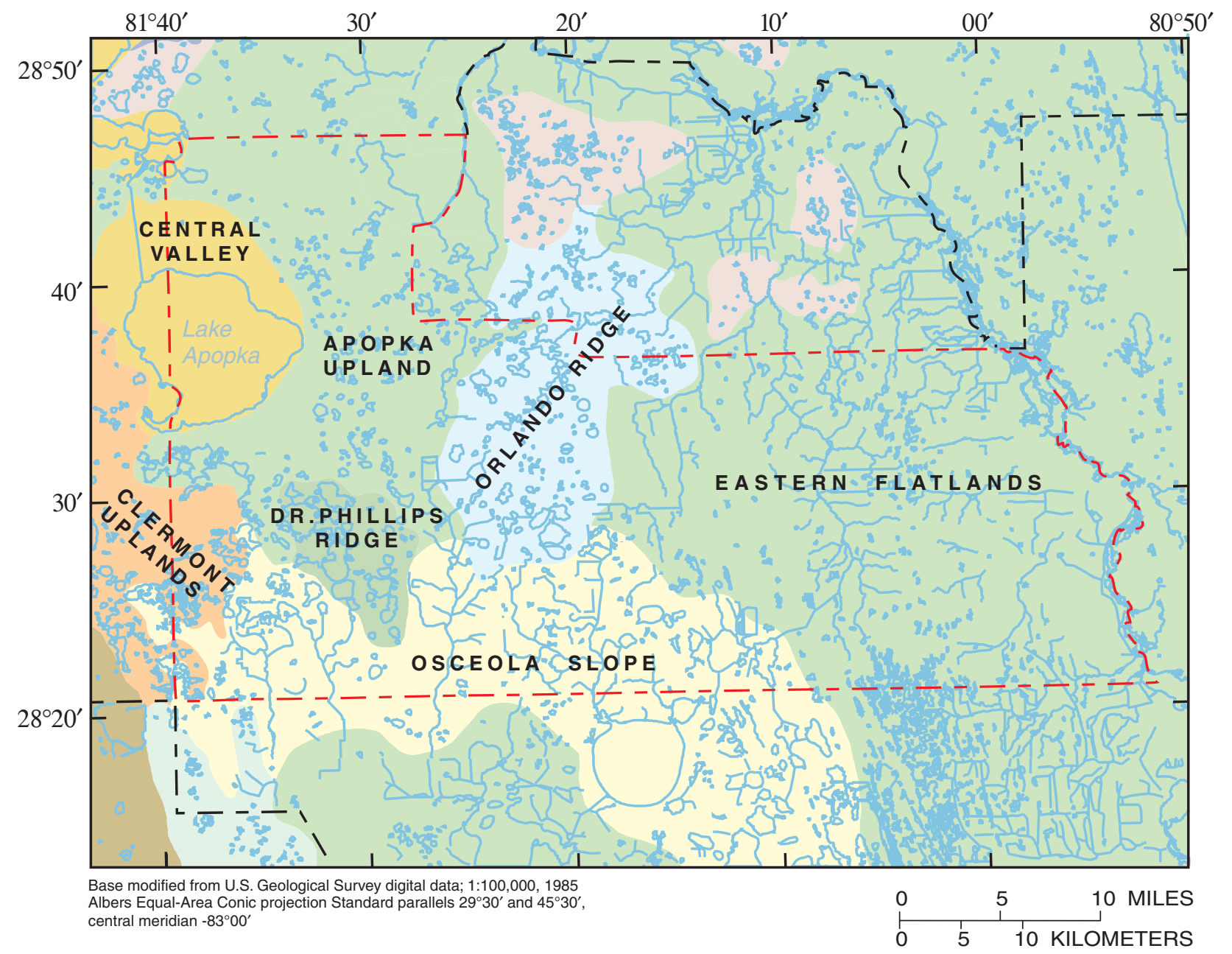

Figure 3. Lake regions of Orange County (modified from Griffith and others, 1997). 


\section{Surface Drainage}

The source of most surface water in Orange County is rainfall, although some water flows into the County from adjacent areas of higher altitude. It is estimated that about 70 percent of the rain that falls on Orange County returns to the atmosphere by evaporation and transpiration, about 20 percent flows out of the County in streams, and about 10 percent is ground water outflow (Lichtler and others, 1968). Drainage wells drilled into the Upper Floridan aquifer dispose of an estimated 33 million gallons per day (Mgal/d) of excess surface drainage in the Orlando area (Tibbals, 1990).

Orange County contains parts of two major watersheds: the Kissimmee River basin and the St. Johns River basin (table 1). The Kissimmee River basin drains to the south and includes the headwaters of the Everglades system. Surface drainage from southwest and south-central Orange County is into the Kissimmee River basin. Streams within that basin discussed in this report include Bonnet Creek, Boggy Creek, Shingle Creek, Cypress Creek, Whittenhorse Creek, and Reedy Creek (fig. 1). The remaining part of the County (eastern and northern parts) lies within the St. Johns River basin. The St. Johns River defines the eastern boundary of Orange County; the river flows north and discharges into the Atlantic Ocean at Jacksonville. Other streams in the St. Johns River basin include the Little Econlockhatchee River, the Econlockhatchee River, the Apopka-Beauclair Canal, and Wekiva River (fig. 1).

\section{Population, Land Use, and Water Use}

Orange County is continuing to experience a large growth in population. In 1920, the population of Orange County was less than 20,000. In 1963, when Lichtler and others (1968) described the water resources of Orange County, the population had increased to about 290,000. In 2000, the population was about 896,000 (Marella, 2004). The increase in population has resulted in land-use changes. A comparison of land use in 1977 with land use in 1997 (fig. 4) shows that the amount of urban area increased around Orlando-from about $140 \mathrm{mi}^{2}$ (14 percent) in 1977 to about $220 \mathrm{mi}^{2}$ (22 percent) in 1997. Relatively little increase in urbanization between 1977-97 occurred in the eastern most one-third of the County.

Total water use in Orange County in 2000 was about $302 \mathrm{Mgal} / \mathrm{d}$ (fig. 5), about 95 percent of which was pumped from the Floridan aquifer system. Most of the usage of surface water is for agricultural irrigation, and until the early 1980s, was for power generation (Marella, 2004). Virtually all water used for public supply is ground water, and usage has increased from $77 \mathrm{Mgal} / \mathrm{d}$ in 1965 to $290 \mathrm{Mgal} / \mathrm{d}$ in 2000, or about a 280 percent increase (Marella, 2004). Some of the water pumped for public supply is transferred to Brevard County (about $26 \mathrm{Mgal} / \mathrm{d}$, or 9 percent of the total public supply use in 2000). This relatively large increase in public-supply usage has been partially offset by a decline in agricultural usage from 1985 to 2000 , so that total water use, inclusive of surface water, has increased from $186 \mathrm{Mgal} / \mathrm{d}$ in 1965 to $302 \mathrm{Mgal} / \mathrm{d}$ in 2000 , or about a 62 percent increase (fig. 5). The decline in agricultural water use after 1985 probably was accelerated by the severely cold winters in the 1980s that badly damaged the citrus industry.

\section{Data Collection and Analysis}

Data described in this report include water quality, water level, rainfall, and rate of streamflow. Data-collection sites include streams and lakes. Data from past investigations of water resources by the USGS and other State and local agencies were compiled and analyzed, along with new data collected during this study.

\section{Precipitation, Streamflow, and Lake Levels}

Daily rainfall data are from nine meteorological stations operated by the NOAA. The rainfall records used to characterize climate of the study area and to develop simple rainfall-streamflow models for trend analyses are from stations shown in figure 6. Appendix A summarizes annual rainfall for the stations. The daily record at some stations begins in 1931 .

The streamflow data for 13 stations described in this report are from the streamflow network operated by the USGS. These data consist of daily means of streamflow, from 1934 to 2000. Station locations are shown in figure 7.

The lake water-level data were collected by the USGS or the Orange County Stormwater Management Division. For some lakes, both the USGS and Orange County maintained records of water levels, but generally not for the same time period. Data collected by USGS and Orange County were combined and analyzed to determine range in lake-level fluctuations and to look for long-term changes in water level. Records of water levels for one lake (Lake Butler) begin in 1933. Figure 8 provides the locations of lakes with more than 15 years of water-level record, each with at least four measurements per year. Appendix B summarizes water levels for these lakes. 


\section{Hydrology and Water Quality of Lakes and Streams in Orange County, Florida}

Table 1. Characteristics of major drainage basins in Orange County, Florida.

[Basin locations are shown in figure 1]

\begin{tabular}{|c|c|c|c|c|}
\hline Basin & $\begin{array}{l}\text { Drainage } \\
\text { area within } \\
\text { Orange County } \\
\text { (square miles) }\end{array}$ & Drains into & $\begin{array}{c}\text { Basin relief } \\
\text { (altitude, in feet) }\end{array}$ & Basin description and comments \\
\hline \multicolumn{5}{|l|}{ Kissimmee River Basin } \\
\hline Kissimmee River & 350 & $\begin{array}{l}\text { Kissimmee River } \\
\text { basin }\end{array}$ & $\begin{array}{l}\text { Wide floodplain, } \\
\text { low slope }\end{array}$ & $\begin{array}{l}\text { Extensive wetlands in floodplain. Much of the flood- } \\
\text { plain is used for agriculture and cattle grazing. }\end{array}$ \\
\hline Boggy Creek & 86 & $\begin{array}{l}\text { Kissimmee River } \\
\text { basin }\end{array}$ & $60-125$ & $\begin{array}{l}\text { Lower basin contains many swampy areas but few } \\
\text { lakes. Upper basin has hills and numerous lakes. }\end{array}$ \\
\hline Bonnet Creek & 55 & $\begin{array}{l}\text { Kissimmee River } \\
\text { basin }\end{array}$ & $75-195$ & $\begin{array}{l}\text { Flat, swampy terrain with several lakes and islands of } \\
\text { low relief. Drainage extensively modified and con- } \\
\text { trolled within the Reedy Creek Improvement } \\
\text { District (RCID). }\end{array}$ \\
\hline Cypress Creek & 32 & $\begin{array}{l}\text { Kissimmee River } \\
\text { basin }\end{array}$ & $90-195$ & $\begin{array}{l}\text { Swampy terrain is common along channel. Rolling } \\
\text { hills characterize the eastern part of basin, with } \\
\text { lakes in the headwaters. A relatively large part of } \\
\text { the basin is lakes. }\end{array}$ \\
\hline Reedy Creek & 49 & $\begin{array}{l}\text { Kissimmee River } \\
\text { basin }\end{array}$ & $75-210$ & $\begin{array}{l}\text { The eastern basin is generally flat, swampy terrain } \\
\text { with islands of low relief. The western basin is } \\
\text { generally rolling hills with lakes and swamps. } \\
\text { Drainage extensively modified and controlled } \\
\text { within the RCID. Received treated wastewater } \\
\text { from RCID from 1972-1991. }\end{array}$ \\
\hline Shingle Creek & 83 & $\begin{array}{l}\text { Kissimmee River } \\
\text { basin }\end{array}$ & $70-175$ & $\begin{array}{l}\text { Relatively flat except for hills on western edge. } \\
\text { Received up to } 22 \text { million gallons per day treated } \\
\text { wastewater from } 1972 \text { until } 1991 \text { when wastewater } \\
\text { was diverted to the Conserv II project. }\end{array}$ \\
\hline Whittenhorse Creek & $12^{\mathrm{a}}$ & Reedy Creek & $100-150$ & $\begin{array}{l}\text { Swampy terrain is common along channel. Basin } \\
\text { contains Bear Bay, a large swampy area. Hills with } \\
\text { numerous sinks are adjacent to the swampy areas. } \\
\text { The upland areas are used for citrus cultivation and } \\
\text { urban developments. }\end{array}$ \\
\hline \multicolumn{5}{|l|}{ St. Johns River Basin } \\
\hline St. Johns River & 664 & Atlantic Ocean & $\begin{array}{l}\text { Wide floodplain, } \\
\text { low slope }\end{array}$ & $\begin{array}{l}\text { Extensive wetlands in floodplain. Much of the flood- } \\
\text { plain is used for agriculture and cattle grazing. }\end{array}$ \\
\hline Apopka-Beauclair Canal & 120 & Lake Dora & $65-225$ & $\begin{array}{l}\text { Mucklands near Lake Apopka. The canal conveys } \\
\text { water from Lake Apopka to Lake Dora. Flow } \\
\text { regulated by control structure. }\end{array}$ \\
\hline Econlockhatchee River & 117 & St. Johns River & $20-90$ & $\begin{array}{l}\text { Basin contains areas of wetland forest and a few } \\
\text { lakes. Area of rapid residential development. }\end{array}$ \\
\hline $\begin{array}{l}\text { Little Econlockhatchee } \\
\text { River }\end{array}$ & 71 & $\begin{array}{l}\text { Econlockhatchee } \\
\text { River }\end{array}$ & $35-127$ & $\begin{array}{l}\text { Basin contains areas of wetland forest and a few } \\
\text { lakes. Area of rapid residential development. }\end{array}$ \\
\hline Wekiva River & 130 & St. Johns River & $15-195$ & $\begin{array}{l}\text { Wetlands near stream channels, changing to rolling } \\
\text { hills with numerous sinks. Streamflow comprised } \\
\text { mostly of spring discharge. Parts of river were } \\
\text { designated wild and scenic. }\end{array}$ \\
\hline
\end{tabular}

ancludes drainage area from adjacent county. 


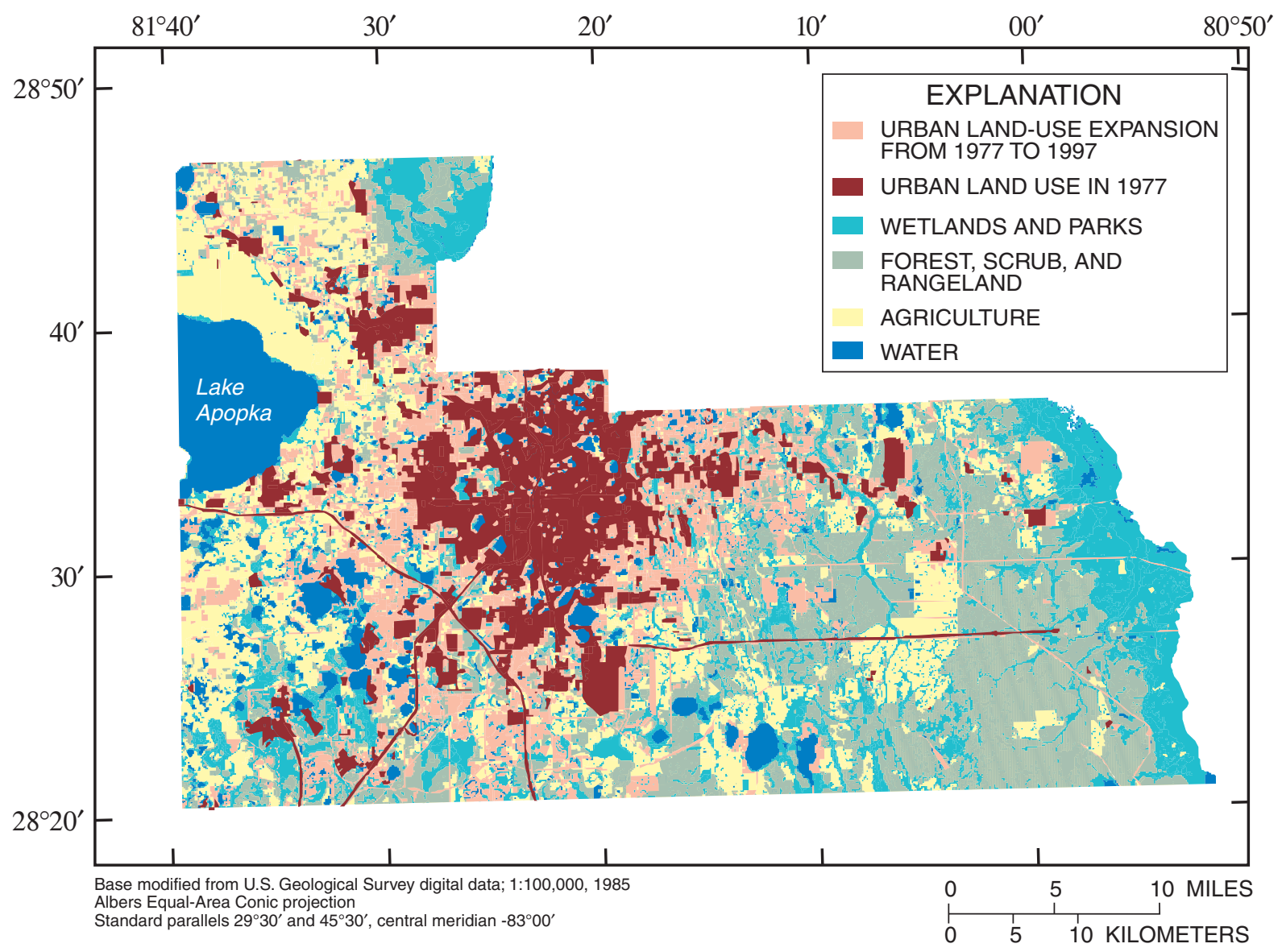

Figure 4. Generalized land use in Orange County in 1997 (source: Orange County Growth Management Department), showing expansion of urban land use since 1977 (based on land-use classifications described in Anderson and others, 1976).

A nonparametric statistical procedure, the Kendall Tau test, was used to quantify temporal trends in rainfall, streamflow, and lake levels, and relations between constituent concentrations and streamflow. A trend is an overall increase or decrease in annual rainfall, lake level, or some annual streamflow characteristic-such as 7-day low flow during a selected period of time. The test was used to determine if changes are evidence of real trends, rather than just random sequences of variation that could be observed in a set of data with no real change with time. The test is nonparametric and is not affected by outlying values.

The Kendall Tau test is described in many textbooks and articles on statistical analysis, such as Conover (1980) and Helsel and Hirsch (1992). The test compares the magnitude of a quantity for each year of record with the magnitudes for all other years, and counts the number of concordant and discordant comparisons. A concordant result is one in which the tested quantity increased from one year to a later year; a discordant result is one in which the test quantity decreased from one year to a later year.
The greater the number of concordant comparisons relative to the number of discordant results, the greater the probability of a trend for increasing values with time. Conversely, a greater number of discordant comparisons indicate a trend for decreasing values with time. The probability computed using the Kendall test procedure is that the relative abundance of concordant and discordant comparisons could be due to chance alone, based on the initial assumption (the null hypothesis) that there is no change in magnitude with time. Small probabilities indicate that there is little chance that a trend indicated by the test could have resulted from a random (and trendless) data set. In this study, a probability of 5 percent or less was the criterion for statistical significance. The Kendall Tau test does not guarantee the detection of trends in all situations. For example, if a tested quantity increased in value for part of the tested period of record and decreased in value for the rest of the period, statistical trend tests would likely indicate no significant trend for the entire period. 


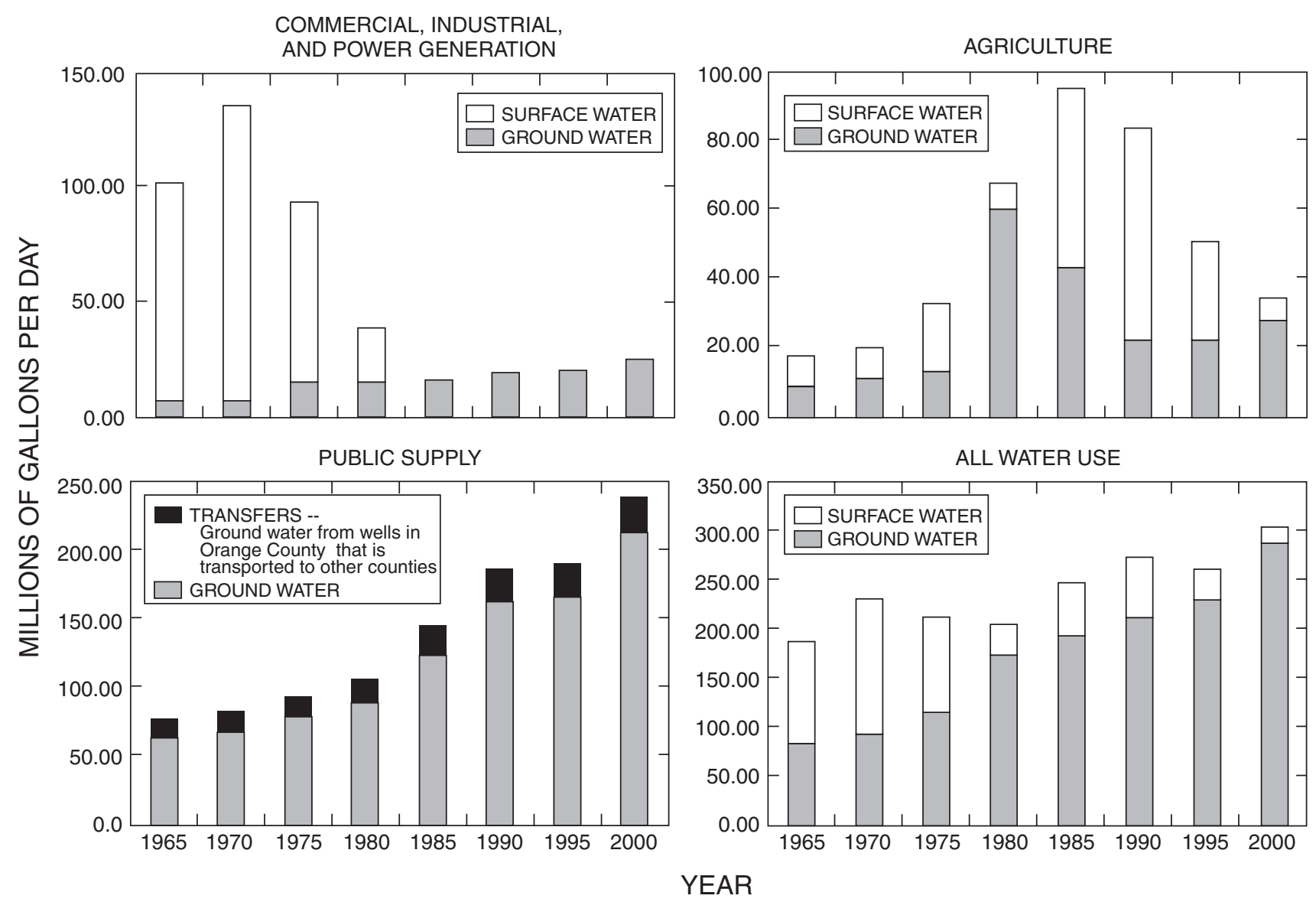

Note. Transfers refer to ground water from wells from Orange County that is transported to other counties for public supply. Totals for the chart showing all water use include recreational and domestic supply usage, as well as the other categories as shown above. Data from U.S. Geological Survey, 2004b.

Figure 5. Summary of water use in Orange County, 1965-2000.

\section{Water Quality}

Water-quality samples were collected from 11 streams during this study. In addition, water-quality data were available for four streams (Cypress Creek, Bonnet Creek, Whittenhorse Creek and Reedy Creek), as part of the USGS data-collection network. The numbers and types of water-quality samples are given in table 2. Locations of the water-quality stations are shown in figure 7.

During this study, 24 lakes were sampled (table 3). Five lakes were sampled seasonally (in the summer and fall of 2000 and in the spring of 2001); three lakes were sampled twice (table 3 ). The remaining 16 lakes were sampled once, generally coinciding with the final seasonal sample collections. Water-quality data from lakes were supplemented with data collected during 2000 and 2001 by the City of Orlando Stormwater Utility Bureau (230 samples from 73 lakes) and by the Orange County Environmental Protection Division (183 samples from 71 lakes). A number of lakes were sampled by more than one agency. Data from 140 lakes were compiled (appendix C). Locations of the lakes with water-quality data are shown in figure 9 .

Field measurements (air and water temperatures, specific conductance, dissolved oxygen, and $\mathrm{pH}$ ) were made and water-quality samples were collected at equal depth increments at each lake. At selected large lakes, field measurements were made at more than one location to assess the spatial variation of water quality in the lake. Field measurements were made and samples collected at equal width increments across the channel at each stream site. The field measurements were made in accordance with USGS protocols (U.S. Geological Survey, variously dated).

Samples were collected from lakes and streams using a 350-milliliter ( $\mathrm{mL})$ bailer constructed of fluorinated ethylene propylene (FEP) and polytetrafluoroethylene (PTFE). The bailer had ball-check valves at the top and bottom for collection and isolation of samples from specific depths. 


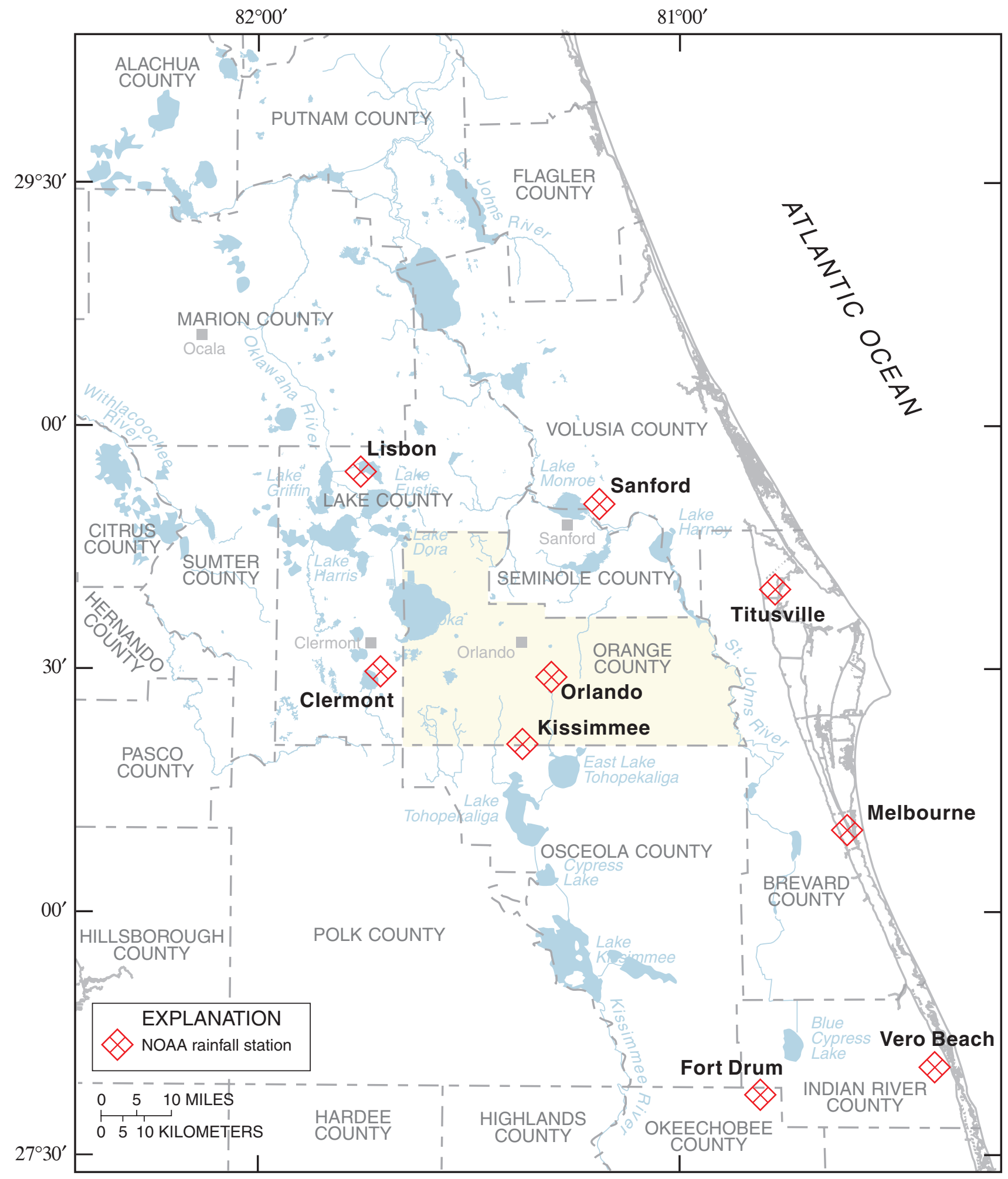

Figure 6. Location of selected National Oceanic Atmospheric Administration rainfall stations in central Florida. 


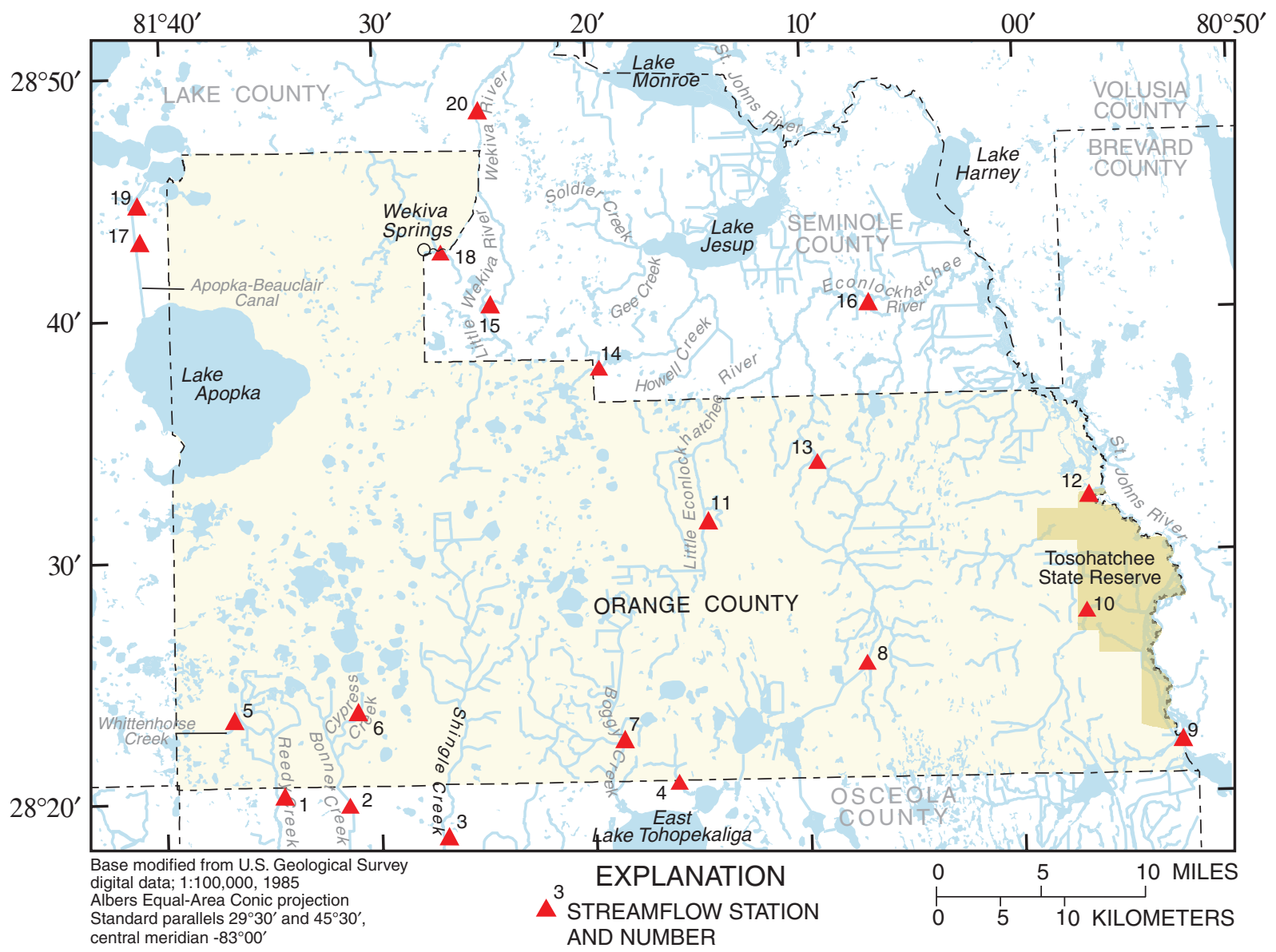

Figure 7. Location of U.S. Geological Survey streamflow and water-quality stations in and near Orange County (map numbers refer to table 2).

Samples were collected for laboratory analysis of alkalinity, major ions, nutrients, silica, selected trace elements, total organic carbon, and chlorophyll- $a$ and $b$. Major ions included calcium, magnesium, sodium, potassium, sulfate, chloride, and fluoride. The nutrient analyses included nitrite (filtered), nitrite plus nitrate (filtered), ammonia (filtered), ammonia plus organic nitrogen (filtered and whole water), phosphorus (filtered and whole water), and phosphate (filtered). The trace element analyses included aluminum, arsenic, barium, beryllium, boron, cadmium, chromium, cobalt, iron, lead, lithium, manganese, selenium, strontium, and vanadium. Samples from selected sites were collected for analysis of 47 pesticides and pesticide metabolites (table 4). Samples from four lakes (Adair, Ellenore, Fairview, and Hope) and four streams (Econlockhatchee River, Little Econlockhatchee River, Little Wekiva River, and Shingle Creek) were analyzed for compounds indicative of household and industrial wastes (table 5).
Samples for inorganic analyses were composited in a plastic churn splitter; samples for organic analyses were composited in a 4-liter amber-glass bottle. Samples were processed with a portable pump equipped with a PTFE diaphragm head and FEP tubing. Samples for major-ion, nutrient, and trace-element analyses were filtered with a 0.45 -micrometer $(\mu \mathrm{m})$ pore-size disposable encapsulated filter. Samples for pesticide analysis were filtered with a 0.7 $\mu \mathrm{m}$ pore-size baked-glass fiber filter in an aluminum filter plate. Whole-water samples were used for analysis of household and industrial waste compounds. Samples for chlorophyll analyses were collected by filtering $100 \mathrm{~mL}$ of sample water with $0.7 \mu \mathrm{m}$ pore-size glass-fiber filters in a polysulfone filter holder. The filter was inserted in a glass vial and chilled. Samples for major-cation and trace-element analyses were acidified with 2-mL nitric acid to adjust sample $\mathrm{pH}$ to less than 2. Whole-water samples for nutrient analysis were preserved with 1-mL sulfuric acid. All samples were chilled to less than 4 degrees Celsius $\left({ }^{\circ} \mathrm{C}\right)$ and shipped overnight to USGS laboratories in Ocala, Florida, and Denver, Colorado. 


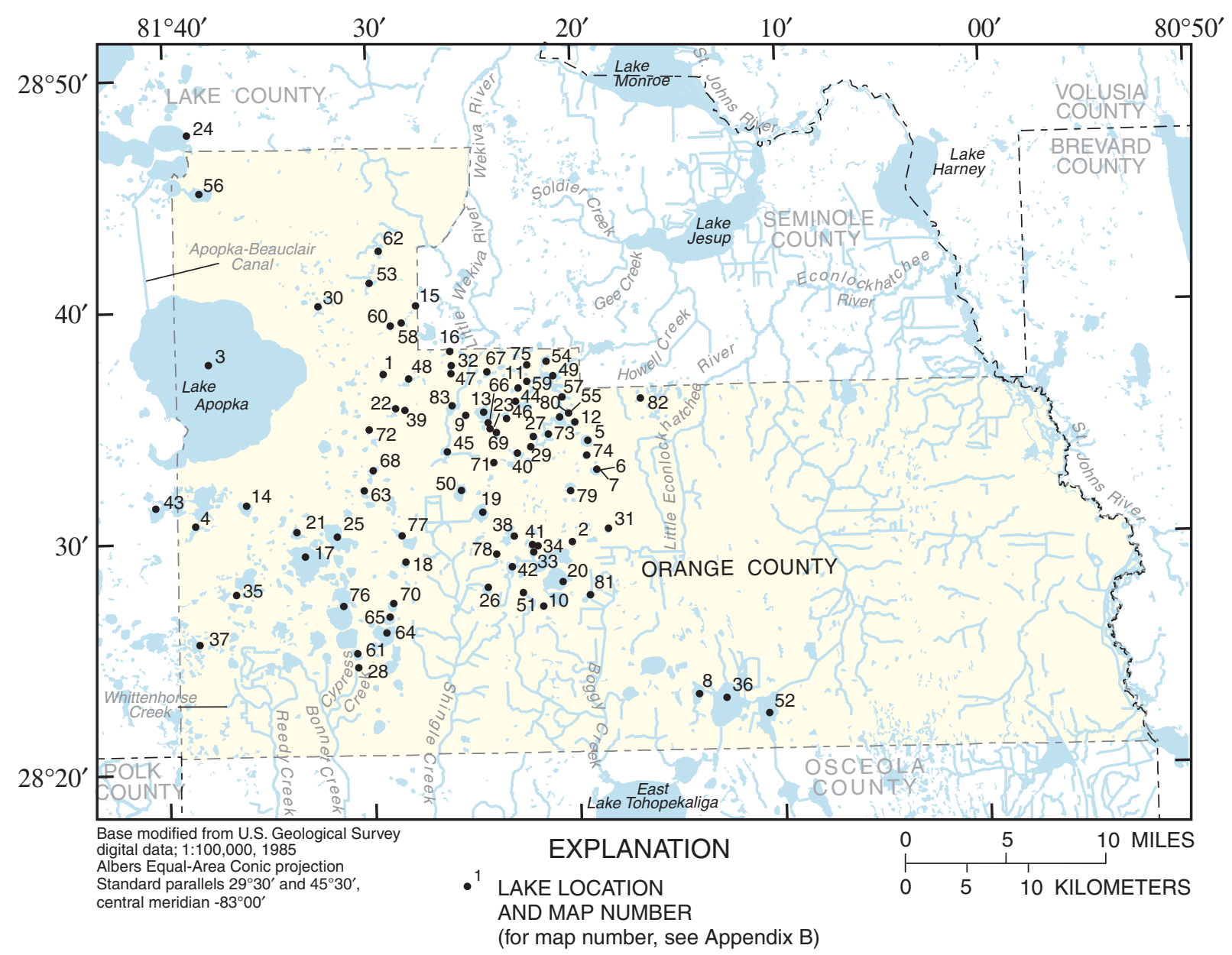

Figure 8. Location of lakes with four or more water-level measurements each year for more than 15 years.

Before moving from one site to another site to collect samples, equipment was washed with a nonphosphatic detergent and rinsed with deionized water to prevent cross contamination. Equipment used for the collection and processing of trace-elements samples also was rinsed with a 5-percent solution of hydrochloric acid and rinsed with deionized water. Equipment used for the collection and processing of pesticide samples was rinsed with pesticidegrade methanol and rinsed with pesticide-free water. Six field blanks and seven replicate samples were collected for quality assurance. Field-blank samples were analyzed for nutrients, trace elements, and pesticides. In general, concentrations of constituents were less than method detection limits in all field-blank samples. In one field-blank sample, the concentration of total organic carbon was 0.6 milligrams per liter $(\mathrm{mg} / \mathrm{L})$. However, total organic carbon also was present in the associated source-solution blank, indicating that the source was not cross contamination or sample-collection techniques.
Duplicate samples were split from the same churn of water as the environmental sample and analyzed for major ions, nutrients, trace elements, and pesticides. In general, results of the environmental and duplicate samples were in good agreement. For example, in both environmental and duplicate samples collected from Jim Creek near Christmas on September 7, 2000, concentrations of barium were 35 micrograms per liter $(\mu \mathrm{g} / \mathrm{L})$, concentrations of beryllium were less than $1.0 \mu \mathrm{g} / \mathrm{L}$, concentrations of boron were $27 \mu \mathrm{g} / \mathrm{L}$, concentrations of lithium were $1.2 \mu \mathrm{g} / \mathrm{L}$, and concentrations of strontium were $410 \mu \mathrm{g} / \mathrm{L}$. In both environmental and duplicate samples collected from Turkey Lake, on October 31, 2000, concentrations of prometon were $0.005 \mu \mathrm{g} / \mathrm{L}$, concentrations of atrazine were $0.017 \mu \mathrm{g} / \mathrm{L}$, and concentrations of diazinon were $0.004 \mu \mathrm{g} / \mathrm{L}$.

Water-quality data collected from 11 streams for the purposes of this study were supplemented with data collected from 4 additional streams (Cypress Creek, Bonnet Creek, Whittenhorse Creek, and Reedy Creek) as part of 
Table 2. Stream sites with streamflow and water-quality data collected by the U.S. Geological Survey, 2000-01.

[Drainage area is in square miles. Data for Cypress Creek, Bonnet Creek, Whittenhorse Creek, and Reedy Creek are from the USGS data-collection network; samples for the other sites were collected as part of this study. Type of data: F, field-measured parameters including specific conductance, dissolved oxygen, pH, and water temperature; I, household and industrial waste compounds; $\mathrm{M}$, major cations and anions; $\mathrm{N}$, nutrients (nitrogen and phosphorus compounds); $\mathrm{P}$, pesticides; $S$, streamflow; $T_{d}$, trace elements in a filtered water sample; $T_{t}$, trace elements in a whole-water sample; $H$, historical data also available for some constituents. Stream locations are shown in fig. 7]

\begin{tabular}{|c|c|c|c|c|c|}
\hline $\begin{array}{l}\text { Map } \\
\text { No. }\end{array}$ & Station name & $\begin{array}{l}\text { USGS } \\
\text { identifier }\end{array}$ & $\begin{array}{c}\text { Total } \\
\text { drainage } \\
\text { area }\end{array}$ & $\begin{array}{c}\text { Type of } \\
\text { data }\end{array}$ & $\begin{array}{c}\text { No. } \\
\text { of } \\
\text { samples }\end{array}$ \\
\hline 9 & St. Johns River near Cocoa & 02232400 & 1,330 & SFMNH & 52 \\
\hline 10 & Jim Creek at Fish Hole Road near Christmas & 02232460 & 47 & $\mathrm{FMNT}_{\mathrm{d}}$ & 2 \\
\hline 12 & St. Johns River near Christmas & 02232500 & 1,540 & SFMNH & 52 \\
\hline 8 & Econlockhatchee River at Magnolia Ranch near Bithlo & 02233001 & 32.9 & SH & 0 \\
\hline 13 & Econlockhatchee River near Bithlo & 02233100 & 119 & $\mathrm{SFMNT}_{\mathrm{d}}$ & 1 \\
\hline 11 & Little Econlockhatchee River near Union Park & 02233200 & 27.1 & $\mathrm{SFMNT}_{\mathrm{d}} \mathrm{PIH}$ & 3 \\
\hline 16 & Econlockhatchee River near Chuluota & 02233500 & 241 & $\mathrm{SFMNT}_{\mathrm{d}} \mathrm{PIH}$ & 3 \\
\hline 14 & Howell Creek near Altamonte Springs & 02234308 & 20.6 & $\mathrm{FMNT}_{\mathrm{d}}$ & 1 \\
\hline 18 & Wekiva River near Apopka & 02234635 & 58.3 & $\mathrm{SFMNT}_{\mathrm{d}} \mathrm{P}$ & 3 \\
\hline 15 & Little Wekiva River near Altamonte Springs & 02234990 & 90.7 & $\mathrm{FMNT}_{\mathrm{d}} \mathrm{PI}$ & 3 \\
\hline 20 & Wekiva River near Sanford & 02235000 & 189 & SFMNH & 9 \\
\hline 17 & Apopka-Beauclair Canal near Astatula & 02237700 & 184 & $\mathrm{SH}$ & 0 \\
\hline 19 & Apopka-Beauclair Canal below dam near Astatula & 02237701 & 184 & $\mathrm{FMNT}_{\mathrm{d}} \mathrm{H}$ & 1 \\
\hline 7 & Boggy Creek near Taft & 02262900 & 83.6 & $\mathrm{SFMNT}_{\mathrm{d}} \mathrm{PH}$ & 3 \\
\hline 3 & Shingle Creek at airport near Kissimmee & 02263800 & 89.2 & $\mathrm{SFMNT}_{\mathrm{d}} \mathrm{PIH}$ & 3 \\
\hline 6 & Cypress Creek at Vineland & 02264000 & 29.3 & $\mathrm{SFMNT}_{\mathrm{t}} \mathrm{H}$ & 7 \\
\hline 2 & Bonnet Creek near Vineland & 02264100 & 44.7 & $\mathrm{FMNT}_{\mathrm{t}} \mathrm{H}$ & 17 \\
\hline 5 & Whittenhorse Creek near Vineland & 02266200 & 12.4 & $\mathrm{SFMNT}_{\mathrm{t}} \mathrm{H}$ & 5 \\
\hline 1 & Reedy Creek near Vineland & 02266300 & 84.6 & $\mathrm{SFMNT}_{\mathrm{t}} \mathrm{H}$ & 16 \\
\hline 4 & Jim Branch near Narcoossee & 282043081155900 & 5.8 & $\mathrm{FMNT}_{\mathrm{d}}$ & 1 \\
\hline
\end{tabular}

the USGS long-term data-collection network. Samplecollection methods differed slightly. For example, wholewater samples were collected at each stream site for traceelement analyses.

Florida trophic state indexes (TSI) were calculated for all lakes with sufficient data using the following set of equations (Brezonik, 1984):

$\mathrm{TSI}=1 / 3\left[\right.$ chla $\left.\left.+\mathrm{SD}+0.5\left(\mathrm{TP}^{1}\right)+\mathrm{TN}^{1}\right)\right]$, for nutrient-balanced lakes;

$\mathrm{TSI}=1 / 3\left[\mathrm{chla}+\mathrm{SD}+\mathrm{TN}^{2}\right]$, for nitrogen-limited lakes; and $\mathrm{TSI}=1 / 3\left[\mathrm{chla}+\mathrm{SD}+\mathrm{TP}^{2}\right]$, for phosphorus-limited lakes.

Nutrient-balanced lakes are considered to be those with a ratio of total nitrogen to total phosphorus (TN/TP) between 10 and 30. A TN/TP ratio of less than 10 indicates a nitrogen-limited lakes, and a TN/TP ratio greater than 30 indicates a phosphorus-limited lake.

The independent variables in the TSI equations are calculated as follows: chla $=16.8+14.4 \ln ($ chlorophyll $-a$ concentration, in $\mu \mathrm{g} / \mathrm{L})$;

$\mathrm{SD}=60-30 \ln$ (secchi disk reading, in meters);

$\mathrm{TN}^{1}=56+19.8 \ln$ (total nitrogen concentration, in $\mathrm{mg} / \mathrm{L}$ as nitrogen);

$\mathrm{TN}^{2}=59.6+21.5 \ln ($ total nitrogen concentration, in $\mathrm{mg} / \mathrm{L}$ as nitrogen);

$\mathrm{TP}^{1}=18.6 \ln ($ total phosphorus concentration, in $\mu \mathrm{g} / \mathrm{L}$ as phosphorus) - 18.4; and

$\mathrm{TP}^{2}=23.6 \ln$ (total phosphorus concentration, in $\mu \mathrm{g} / \mathrm{L}$ as phosphorus) - 23.8.

Data were analyzed spatially and statistically to illustrate the occurrence and distribution of water-quality constituents and assess factors affecting water quality. Factors qualitatively and quantitatively assessed include size of lake (perimeter), land use, lake region, and geology of the basin. The analyses were done with geographical information systems (GIS) and nonparametric statistical methods. Similar analyses were performed for water-quality data collected from the streams. 
Table 3. Lakes sampled by the U.S. Geological Survey, 2000-01.

[Type of data: $\mathrm{F}$, field-measured parameters including specific conductance, dissolved oxygen, $\mathrm{pH}$, and water temperature; $\mathrm{M}$, major cations and anions; $\mathrm{N}$, nutrients (nitrogen and phosphorus compounds); $T_{d}$, trace elements in a filtered water sample; $P$, pesticides; I, household and industrial waste compounds. Map numbers refer to fig. 9 and appendix C]

\begin{tabular}{|c|c|c|c|c|c|c|}
\hline $\begin{array}{l}\text { Map } \\
\text { No. }\end{array}$ & Lake name & $\begin{array}{l}\text { Station } \\
\text { identifier }\end{array}$ & Latitude & Longitude & $\begin{array}{l}\text { Type } \\
\text { of } \\
\text { data }\end{array}$ & $\begin{array}{c}\text { No. } \\
\text { of } \\
\text { samples }\end{array}$ \\
\hline 1 & Johns Lake at Oakland & 02237540 & 283230 & 0813828 & FMNTd & 1 \\
\hline 2 & Lake Adair at Orlando & 02234205 & 283329 & 0812320 & $\mathrm{FMNT}_{\mathrm{d}} \mathrm{PI}$ & 1 \\
\hline 3 & Lake Beuclair (eastern shore) near Mt. Dora & 284617081390200 & 284617 & 0813902 & $\mathrm{FMNT}_{\mathrm{d}}$ & 1 \\
\hline 4 & Lake Fairview at Orlando & 02234812 & 283522 & 0812420 & $\mathrm{FMNT}_{\mathrm{d}} \mathrm{PI}$ & 3 \\
\hline 5 & Lake Hart near Narcoossee & 02262200 & 282246 & 0811327 & $\mathrm{FMNT}_{\mathrm{d}} \mathrm{P}$ & 3 \\
\hline 6 & Hickorynut Lake near Oakland & 02266275 & 282540 & 0813840 & $\mathrm{FMNT}_{\mathrm{d}} \mathrm{P}$ & 2 \\
\hline 7 & Lake Hope at Maitland & 02234297 & 283824 & 0812215 & $\mathrm{FMNT}_{\mathrm{d}} \mathrm{PI}$ & 2 \\
\hline 8 & Lake Ivanhoe at Orlando & 02234225 & 283326 & 0812234 & $\mathrm{FMNT}_{\mathrm{d}}$ & 1 \\
\hline 9 & Lake Jackson near Apopka & 284000081275000 & 284000 & 0812750 & $\mathrm{FMNT}_{\mathrm{d}} \mathrm{P}$ & 1 \\
\hline 10 & Lake Lotta near Ocoee & 283305081304200 & 283304 & 0813048 & $\mathrm{FMNT}_{\mathrm{d}}$ & 1 \\
\hline 11 & Lake Louise near Bithlo & 283528081055300 & 283528 & 0810553 & $\mathrm{FMNT}_{\mathrm{d}} \mathrm{P}$ & 3 \\
\hline 12 & Lake Maitland at Winter Park & 02234300 & 283649 & 0812035 & $\mathrm{FMNT}_{\mathrm{d}}$ & 1 \\
\hline 13 & Lake Mary Jane near Narcoosee & 02261900 & 282246 & 0811115 & $\mathrm{FMNT}_{\mathrm{d}}$ & 1 \\
\hline 14 & Lake Ola at Tangerine & 02237745 & 284510 & 0813800 & $\mathrm{FMNT}_{\mathrm{d}} \mathrm{P}$ & 3 \\
\hline 15 & Lake Oliver near Vineland & 282210081385100 & 282210 & 0813851 & $\mathrm{FMNT}_{\mathrm{d}}$ & 1 \\
\hline 16 & Lake Underhill & 283219081201302 & 283219 & 0812013 & $\mathrm{FMNT}_{\mathrm{d}}$ & 1 \\
\hline 17 & Marshall Lake near Apopka & 284034081315700 & 284034 & 0813157 & $\mathrm{FMNT}_{\mathrm{d}} \mathrm{P}$ & 1 \\
\hline 18 & Lake Ellenore near Pine Castle & 282927081235000 & 282927 & 0812350 & $\mathrm{FMNT}_{\mathrm{d}} \mathrm{PI}$ & 1 \\
\hline 19 & Pond at Tosohatchee State Park near Christmas & 282657080561900 & 282657 & 0805619 & $\mathrm{FMNT}_{\mathrm{d}} \mathrm{P}$ & 2 \\
\hline 20 & Pond No. 2 at Tosohatchee near Christmas & 282702080554200 & 282702 & 0805542 & $\mathrm{FMNT}_{\mathrm{d}}$ & 1 \\
\hline 21 & Raccoon Lake near Windermere & 282102081374600 & 282102 & 0813746 & $\mathrm{FMNT}_{\mathrm{d}} \mathrm{P}$ & 1 \\
\hline 22 & Reedy Lake near Vineland & 282452081370200 & 282452 & 0813702 & $\mathrm{FMNT}_{\mathrm{d}}$ & 1 \\
\hline 23 & Sink on Hartzog Road near Vineland & 282450081375100 & 282450 & 0813751 & $\mathrm{FMNT}_{\mathrm{d}}$ & 1 \\
\hline 24 & Turkey Lake at Orlando & 283019081283100 & 283019 & 0812831 & $\mathrm{FMNT}_{\mathrm{d}} \mathrm{P}$ & 3 \\
\hline
\end{tabular}

Historical water-quality data for eight stream sites in and around Orange County (table 2) were retrieved from the USGS National Water Information System (NWIS) database for long-term (1960 to 2001) trend analysis. Data were retrieved for field measurements (water temperature, dissolved oxygen, $\mathrm{pH}$, and alkalinity), major cations (calcium, magnesium, sodium, and potassium), anions (sulfate, chloride, and fluoride), and nutrients (nitrate, ammonia plus organic nitrogen, and phosphorus). However, a nearly complete record was available for only two of the eight sites: Reedy Creek near Vineland and Bonnet Creek near Vineland. USGS data from three of the eight sites (Boggy Creek near Taft, Econlockhatchee River near Chuluota, and Shingle Creek at airport near Kissimmee) were supplemented with data collected by Orange County (Orange County Environmental Protection Division, 2002). Long-term data for the other three sites (Little
Econlockhatchee River near Union Park, Cypress Creek at Vineland, and Whittenhorse Creek near Vineland) are not available.

After the data were compiled, data from duplicate samples (collected at the same date and time for quality assurance) were removed. In addition, data from samples collected during times of no flow (zero discharge) were not used.

Interpretation of data from long-term sites is complicated by the fact that sample collection and analysis methods have changed. For example, major-ion data included collection and analysis of both whole water (also referred to as total) and filtered (also referred to as dissolved) samples. Also, the manner of reporting some constituents has changed. In records prior to the 1970 s, nitrate concentrations were given as $\mathrm{mg} / \mathrm{L}$ as nitrate. After the mid-1970s, nitrate concentrations were given as $\mathrm{mg} / \mathrm{L}$ as nitrogen. 


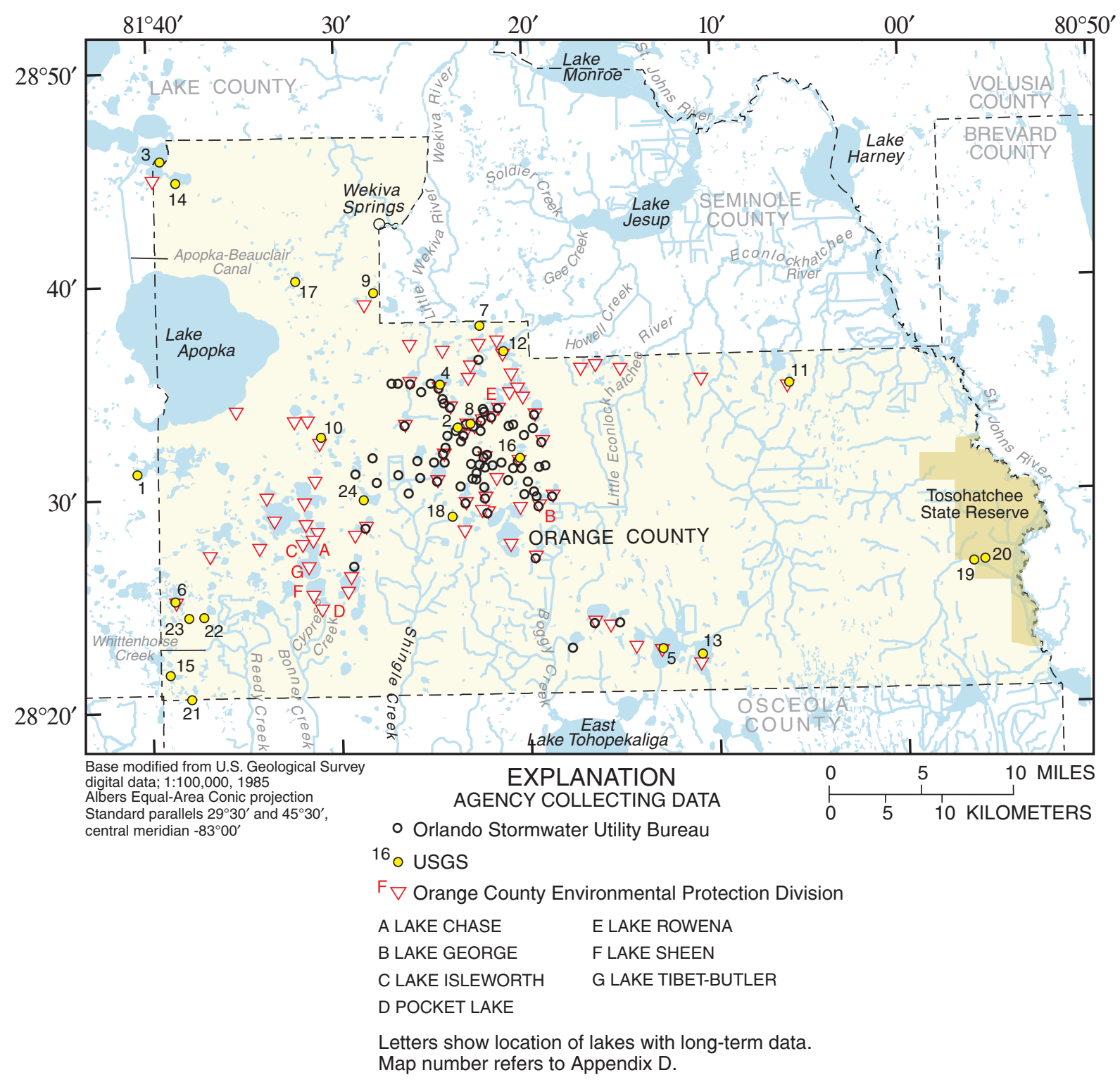

Figure 9. Location of lakes with water-quality data in and around Orange County.

Hence, to obtain consistent, long-term records of each constituent, data were merged or converted. Concentrations of major ions analyzed in whole-water samples were used to supplement concentrations of major ions analyzed in filtered water samples. Field and laboratory alkalinity data were merged. Alkalinity concentrations were converted to bicarbonate concentrations, which were used in the trend analysis.

Nitrate concentrations reported as $\mathrm{mg} / \mathrm{L}$ as nitrate were converted to $\mathrm{mg} / \mathrm{L}$ as nitrogen. Nitrate concentrations analyzed on whole-water samples were used to supplement nitrate concentrations analyzed on filtered water samples. Similarly, all available nitrite data were com- bined. Finally, nitrite concentrations were added to nitrate concentrations to obtain nitrite plus nitrate, in $\mathrm{mg} / \mathrm{L}$ as nitrogen.

Whole-water organic nitrogen concentrations generally were greater than filtered water organic nitrogen concentrations; hence, data from filtered and whole-water samples could not be merged. Whole-water organic nitrogen data were more numerous, and consequently, were used for data analysis. Both filtered and whole-water ammonia data (which were comparable), in $\mathrm{mg} / \mathrm{L}$ as nitrogen, were added to the whole-water organic nitrogen concentrations to obtain ammonia plus organic nitrogen, in $\mathrm{mg} / \mathrm{L}$ as nitrogen. 
Table 4. Pesticide and pesticide metabolite compounds sampled, 2000-01.

[Parameter code refers to number used to identify compounds in data base]

\begin{tabular}{|c|c|c|c|c|c|}
\hline Compound & $\begin{array}{l}\text { Parameter } \\
\text { code }\end{array}$ & $\begin{array}{l}\text { Minimum } \\
\text { reporting } \\
\text { unit }\end{array}$ & Compound & $\begin{array}{l}\text { Parameter } \\
\text { code }\end{array}$ & $\begin{array}{c}\text { Minimum } \\
\text { reporting } \\
\text { level }\end{array}$ \\
\hline Acetochlor & 49260 & 0.006 & Methyl Parathion & 82667 & 0.015 \\
\hline Alachlor & 46342 & .005 & Metolachlor & 39415 & .013 \\
\hline alpha-HCH & 34253 & .005 & Metribuzin & 82630 & .006 \\
\hline Atrazine & 39632 & .007 & Molinate & 82671 & .003 \\
\hline Azinphos-methyl & 82686 & .050 & Napropamide & 82684 & .007 \\
\hline Benfluralin & 82673 & .010 & $\mathrm{p}, \mathrm{p}^{\prime}-\mathrm{DDE}$ & 34653 & .003 \\
\hline Butylate & 04028 & .004 & Parathion & 39542 & .010 \\
\hline Carbaryl & 82680 & .041 & Pebulate & 82669 & .004 \\
\hline Carbofuran & 82674 & .020 & Pendimethalin & 82683 & .022 \\
\hline $\begin{array}{l}\text { 2-Chloro-4-isopropylamino-6- } \\
\text { amino-s-triazine (CIAT) }\end{array}$ & 04040 & .006 & cis-Permethrin & 82687 & .006 \\
\hline Chlorpyrifos & 38933 & .005 & Phorate & 82664 & .011 \\
\hline Cyanazine & 04041 & .018 & Prometon & 04037 & .005 \\
\hline Dacthal (DCPA) & 82682 & .003 & Propachlor & 04024 & .025 \\
\hline Diazinon & 39572 & .005 & Propanil & 82679 & .011 \\
\hline Dieldrin & 39381 & .009 & Propargite & 82685 & .023 \\
\hline 2,6-Diethylaniline & 82660 & .006 & Propyzamide (Pronamide) & 82676 & .004 \\
\hline Disulfoton & 82677 & .021 & Simazine & 04035 & .005 \\
\hline EPTC & 82668 & .004 & Tebuthiuron & 82670 & .016 \\
\hline Ethalfluralin & 82663 & .009 & Terbacil & 82665 & .034 \\
\hline Ethoprophos & 82672 & .005 & Terbufos & 82675 & .017 \\
\hline Fonofos & 04095 & .003 & Thiobencarb & 82681 & .010 \\
\hline Lindane & 39341 & .004 & Tri-allate & 82678 & .002 \\
\hline Linuron & 82666 & .035 & Trifluralin & 82661 & .009 \\
\hline Malathion & 39532 & .027 & & & \\
\hline
\end{tabular}

Phosphorus data included both filtered and wholewater samples, analyzed as total phosphorus and (or) phosphate, and reported in $\mathrm{mg} / \mathrm{L}$ as phosphorus or phosphate. Only total phosphorus data from whole-water samples, in $\mathrm{mg} / \mathrm{L}$ as phosphorus, were sufficiently numerous for trend analysis. These data were supplemented with total phosphorus data from whole-water samples reported in $\mathrm{mg} / \mathrm{L}$ as phosphate after converting to $\mathrm{mg} / \mathrm{L}$ as phosphorus.

Furthermore, because analytical methods have changed, detection and reporting limits have changed during the period of record; hence, many constituents had more than one reporting limit. In general, where more than one reporting limit existed, all data for the constituent that were less than the highest reporting limit were censored and assigned a value of one-half the reporting limit for statistical testing purposes (Helsel and Hirsch, 1992).
Data from Boggy Creek (map no. 7), Bonnet Creek (map no. 2), Econlockhatchee River (map no. 16), and Whittenhorse Creek (map no. 5) (fig. 7) were analyzed quantitatively for temporal trends. The procedure for temporal trend testing differed according to whether or not the constituent values were significantly related to discharge. If a significant discharge relation exists, the effects of varying discharge must be removed from the constituent values before proceeding with trend testing. If this is not done, the trend testing may reflect changes in water quality that are related to changes in discharge, rather than time. Or, the variability in concentration due to changes in discharge may mask underlying temporal trends in water quality. Therefore, prior to trend testing, the relations of constituent values to discharge were determined using Spearman's rank correlation coefficient (rho). The relations were considered significant if the probability that rho was not equal to zero (no relation) was less than 5 percent. 
Table 5. Compounds associated with wastewater sampled, 2000-01.

[ $\mu \mathrm{g} / \mathrm{L}$, micrograms per liter. S, suspected; K, known. F, fungicide; H, herbicide; I, insecticide; GUP, general use pesticide; FR, flame retardant; manuf, manufacturing. Parameter code refers to number used to identify compounds in data base]

\begin{tabular}{|c|c|c|c|c|}
\hline Compound names & $\begin{array}{c}\text { Endocrine } \\
\text { disrupting } \\
\text { potential }\end{array}$ & $\begin{array}{l}\text { Parameter } \\
\text { code }\end{array}$ & $\begin{array}{l}\text { Common use, application, } \\
\text { or occurrence }\end{array}$ & $\begin{array}{l}\text { Minimum } \\
\text { reporting } \\
\text { level }(\mu \mathrm{g} / \mathrm{L})\end{array}$ \\
\hline 1,4-Dichlorobenzene & $\mathrm{S}$ & 34572 & moth repellent, fumigant, deodorant & 0.5 \\
\hline 1-Methylnaphthalene & & 62054 & $\begin{array}{l}\text { nearly equal concentrations ( } 2-5 \% \text { ) in gasoline/ } \\
\text { diesel/crude }\end{array}$ & .5 \\
\hline 2,6-Dimethylnaphthalene & & 62055 & indicator of diesel, kerosene (not much in gasoline) & .5 \\
\hline 2-Methylnaphthalene & & 62056 & $\begin{array}{l}\text { nearly equal concentrations (2-5\%) in gasoline/ } \\
\text { diesel/crude }\end{array}$ & .5 \\
\hline 3-beta-coprostanol & & 62057 & usually a carnivore fecal indicator & 2.0 \\
\hline 3-Methyl-1(H)-indole (skatol) & & 62058 & fragrance: odor in feces and coal tar & 1.0 \\
\hline 3-tert-Butyl-4-hydroxy anisole (BHA) & $\mathrm{K}$ & 62059 & antioxidant, preservative & 5.0 \\
\hline 4-Cumylphenol & $\mathrm{K}$ & 62060 & nonionic detergent metabolite & 1.0 \\
\hline 4-n-Octylphenol & $\mathrm{K}$ & 62061 & nonionic detergent metabolite & 1.0 \\
\hline 4-tert-Octylphenol & $\mathrm{K}$ & 62062 & nonionic detergent metabolite & 1.0 \\
\hline 5-Methyl-1H-benzotriazole & & 62063 & antioxidant in antifreeze, deicers & 2.0 \\
\hline Acetophenone & & 62064 & $\begin{array}{l}\text { fragrance: soap, detergent, tobacco; flavor: } \\
\text { beverages }\end{array}$ & .5 \\
\hline $\begin{array}{l}\text { Acetyl hexamethyl tetrahydronaphtha- } \\
\text { lene (AHTN) }\end{array}$ & & 62065 & $\begin{array}{l}\text { fragrance: musk, widespread usage, persistent in } \\
\text { ground-water }\end{array}$ & .5 \\
\hline Anthracene & & 34221 & wood preservative, in tar/diesel/crude (not gasoline) & .5 \\
\hline Anthraquinone & & 62066 & manuf dye/textiles; seed treatment, bird repellent & .5 \\
\hline Benzo(a)pyrene & $\mathrm{K}$ & 34248 & $\begin{array}{l}\text { regulated polychlorinated aromatic hydrocarbon, } \\
\text { used in cancer research }\end{array}$ & .5 \\
\hline Benzophenone & $\mathrm{S}$ & 62067 & fixative for perfumes and soaps & .5 \\
\hline beta-Sitosterol & & 62068 & generally a plant sterol & 2.0 \\
\hline beta-Stigmastanol & & 62086 & generally a plant sterol & 2.0 \\
\hline Bisphenol A & $\mathrm{K}$ & 62069 & manuf polycarbonate resins; antioxidant, FR & 1.0 \\
\hline Bromacil & & 04029 & H, GUP; $>80 \%$ noncrop grass/brush control & .5 \\
\hline Bromoform & & 34288 & $\begin{array}{l}\text { byproduct of wastewater ozination, military } \\
\text { uses/explosives }\end{array}$ & .5 \\
\hline Caffeine & & 50305 & medical: diuretic; highly mobile/biodegradable & .5 \\
\hline Camphor & & 62070 & flavor, odorant, in ointments & .5 \\
\hline Carbaryl & $\mathrm{K}$ & 82680 & $\begin{array}{l}\text { I, crop and garden uses, low environmental } \\
\text { persistence }\end{array}$ & 1.0 \\
\hline Carbazole & & 62071 & manuf dyes, explosives, and lubricants, I & .5 \\
\hline Chlorpyrifos & $\mathrm{K}$ & 38933 & $\begin{array}{l}\text { domestic pest/termite control; highly restricted } \\
\text { (2000) }\end{array}$ & .5 \\
\hline Cholesterol & & 62072 & often a fecal indicator, also a plant sterol & 2.0 \\
\hline Cotinine & & 62005 & primary nicotine metabolite & 1.0 \\
\hline Diazinon & $\mathrm{K}$ & 39572 & $\mathrm{I},>40 \%$ nonagricultural uses, ants, flies, etc. & .5 \\
\hline Dichlorvos & $\mathrm{S}$ & 38775 & $\begin{array}{l}\text { I, pet collars, fly spray; breakdown of naled and } \\
\text { trichlofon }\end{array}$ & 1.0 \\
\hline d-Limonene & & 62073 & $\mathrm{~F}$, antimicrobial, antiviral; fragrance in aerosols & .5 \\
\hline Fluoranthene & & 34377 & common in coal tar/asphalt (not gasoline/diesel) & .5 \\
\hline $\begin{array}{l}\text { Hexahydrohexamethyl } \\
\text { Cyclopentabenzopyran (HHCB) }\end{array}$ & & 62075 & $\begin{array}{l}\text { fragrance: musk; widespread usage, persistent in } \\
\text { ground-water }\end{array}$ & .5 \\
\hline
\end{tabular}


Table 5. Compounds associated with wastewater sampled, 2000-01. (Continued)

[ $\mu \mathrm{g} / \mathrm{L}$, micrograms per liter. S, suspected; K, known. F, fungicide; H, herbicide; I, insecticide; GUP, general use pesticide; FR, flame retardant; manuf, manufacturing. Parameter code refers to number used to identify compounds in data base]

\begin{tabular}{|c|c|c|c|c|}
\hline Compound names & $\begin{array}{c}\text { Endocrine } \\
\text { disrupting } \\
\text { potential }\end{array}$ & $\begin{array}{l}\text { Parameter } \\
\text { code }\end{array}$ & $\begin{array}{c}\text { Common use, application, } \\
\text { or occurrence }\end{array}$ & $\begin{array}{c}\text { Minimum } \\
\text { reporting } \\
\text { level }(\mu \mathrm{g} / \mathrm{L})\end{array}$ \\
\hline Indole & & 62076 & pesticide inert, fragrance: coffee & 0.5 \\
\hline Isoborneol & & 62077 & fragrance: perfumery, disinfectants & .5 \\
\hline Isophorone & & 34409 & solvent for lacquers, plastics, oils, silicon, resins & .5 \\
\hline Isopropylbenzene (cumene) & & 62078 & $\begin{array}{l}\text { manuf phenol/acetone; component of fuels/paint } \\
\text { thinner }\end{array}$ & .5 \\
\hline Isoquinoline & & 62079 & flavors and fragrances & .5 \\
\hline Menthol & & 62080 & cigarettes, cough drops, liniment, mouthwash & .5 \\
\hline Metalaxyl & & 50359 & H, F, GUP, soil pathogens, mildew, blight, golf turf & .5 \\
\hline Methyl salicylate & & 62081 & liniment, food, beverage, UV-adsorbing lotions & .5 \\
\hline Metolachlor & & 39415 & $\mathrm{H}, \mathrm{GUP}$, indicator of agricultural drainage & .5 \\
\hline N,N'-diethyl-methyl-toluamide (DEET) & & 62082 & I, urban uses, mosquito control & .5 \\
\hline Naphthalene & & 34443 & fumigant, moth repellent, about $10 \%$ of gasoline & .5 \\
\hline Nonylphenol, diethoxy- total (NPEO2) & $\mathrm{K}$ & 62083 & nonionic detergent metabolite & 5.0 \\
\hline Octylphenol, diethoxy- (OPEO2) & $\mathrm{K}$ & 61705 & nonionic detergent metabolite & 1.0 \\
\hline Octylphenol, monoethoxy- (OPEO1) & $\mathrm{K}$ & 61706 & nonionic detergent metabolite & 1.0 \\
\hline para-Cresol & $\mathrm{S}$ & 62084 & wood preservative & 1.0 \\
\hline para-nonylphenol (total) & $\mathrm{K}$ & 62085 & nonionic detergent metabolite & 5.0 \\
\hline Pentachlorophenol & $\mathrm{S}$ & 34459 & $\mathrm{H}, \mathrm{F}$, wood preservative, termite control & 2.0 \\
\hline Phenanthrene & & 34462 & manuf explosives; in tar/diesel/crude (not gasoline) & .5 \\
\hline Phenol & & 34466 & disinfectant, manuf of several products, leachate & .5 \\
\hline Prometon & & 04037 & $\mathrm{H}$, only noncrop areas, applied prior to blacktop & .5 \\
\hline Pyrene & & 34470 & common in coal tar/asphalt (not gasoline/diesel) & .5 \\
\hline Tetrachloroethylene & & 34476 & solvent, degreaser; veterinary: anthelminic & .5 \\
\hline tri(2-Chloroethyl) phosphate & $\mathrm{S}$ & 62087 & plasticizer, FR & .5 \\
\hline tri(Dichlorisopropyl) phosphate & $\mathrm{S}$ & 62088 & FR & .5 \\
\hline Tributylphosphate & & 62089 & antifoaming agent, FR & .5 \\
\hline Triclosan & $\mathrm{S}$ & 62090 & $\begin{array}{l}\text { disinfectant, antimicrobial (concern: induced } \\
\text { resistance) }\end{array}$ & 1.0 \\
\hline Triethyl citrate (ethyl citrate) & & 62091 & cosmetics, pharmaceuticals, widely used & .50 \\
\hline Triphenyl phosphate & & 62092 & plasticizer, resins, waxes, finishes, roofing paper, FR & .5 \\
\hline tris(2-Butoxyethyl) phosphate & & 62093 & FR & .5 \\
\hline
\end{tabular}

Values of constituents that were not related significantly to discharge were tested for temporal trends using Kendall's tau test to relate constituent value to sample date. The null hypothesis - that no trend in the data exists-was rejected if the $\mathrm{p}$-value was less than 5 percent $(\mathrm{p}<0.05)$ (Helsel and Hirsch, 1992).

Constituents that were significantly related to discharge were further analyzed to determine if the distribution of the constituent values and the associated discharges were normally distributed and had constant variance over the range of values. Data that were not normally distributed or did not have a constant variance were transformed using either the square root or logarithm (Helsel and Hirsch, 1992).

Regression analysis was used to determine the relation between constituent value and discharge, using either raw data or transformed data, as appropriate. The residual, or the difference between the constituent value and the regression-predicted constituent value for the associated discharge, was computed for each sample. These residuals, 
referred to as flow-adjusted values, generally are free of the effects of varying discharge and are suitable for trend testing using Kendall's tau.

Data from Reedy Creek could not be analyzed with the methods described above because of the contribution of treated wastewater to the stream from about 1972 to about 1992 (Hampson, 1993; Sumner and Bradner, 1996). The data set was divided into three time periods (pre-1972, 1972-91, and 1992-2001) based on the input of the treated wastewater. Data from these periods were statistically analyzed for differences in rank sums using the nonparametric Kruskal-Wallis test. The Kruskal-Wallis test is similar to the Wilcoxon test that was used in the analysis of trends in streamflow and rainfall, except that more than two time periods are used. Both tests are based on comparison of summed ranks of constituent values for the specified time periods, rather than the actual constituent values.

Data from Shingle Creek and the Little Econlockhatchee River had large temporal gaps and were insufficient for quantitative trend analysis. Data from Cypress Creek also were not quantitatively analyzed because Cypress Creek is a tributary of Bonnet Creek. However, the data from these three streams are summarized in this report.

\section{HYDROLOGY}

Precipitation, streamflow, and lake-level data were summarized to determine annual and seasonal variation. The data also were examined for the presence of temporal trends. Trends in streamflow and lake levels have occurred in the Orange County area. It was not always possible to determine precisely the reasons for these temporal trends; however, generalized reasons for trends are suggested when possible.

\section{Annual, Seasonal, and Daily Variation}

Daily values of rainfall and streamflow were compiled to provide monthly, seasonal, and annual totals or means. For lake levels, however, generally only periodic observations (four or less per year) were available. For a few lakes, daily values of lake levels were available.

\section{Precipitation}

Records of annual precipitation were compiled for nine NOAA rainfall stations in or adjacent to Orange County (fig. 6). At some stations, data were available from 1931-2000 (appendix A). Not all stations had record for the entire 70-year period, but the period of record at all sites (at least 42 years) is adequate to define rainfall patterns that occurred during the period of surface-water data collection. Mean-annual rainfall totals (1931-2000) vary in the vicinity of Orange County from 48.46 inches at Lisbon to 55.15 inches at Titusville. The mean-annual rainfall total for Orlando is 49.92 inches (1931-2000). The highest annual rainfall total measured in Orlando was 68.67 inches in 1960 and the lowest was 30.38 inches in 2000.

Most of the rainfall in Orange County generally occurs during June through September (fig. 10); this 4month period is commonly referred to as the wet season.

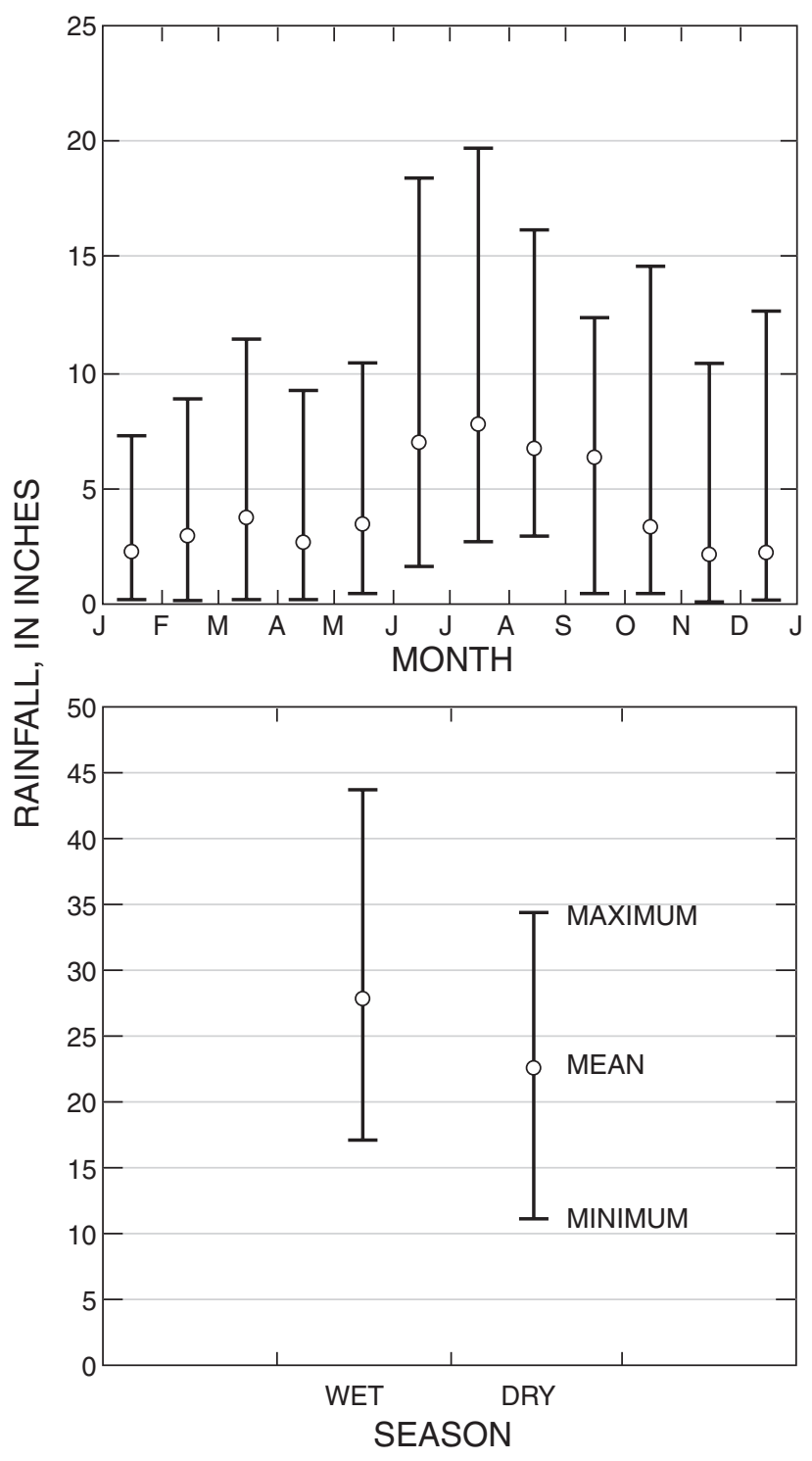

Figure 10. Monthly and seasonal variation in rainfall at Orlando, 1931-2000. 
The remaining 8 months (October through May) commonly are referred to as the dry season. During the wet season, average monthly rainfall totals exceed 6 inches at Orlando (1931-2000). In comparison, average monthly rainfall totals during the dry season at Orlando are less than 4 inches. The wettest month in Orange County typically is July, with an average monthly rainfall total of nearly 8 inches (1931-2000). More than one-half of the annual total rainfall in Orange County typically falls during the wet season. The average wet-season rainfall at Orlando was 28.13 inches (1931-2000); the average dryseason rainfall was 21.84 inches. However, there are periods when the most annual rainfall occurred during the dry season in Orange County. For example, 34.22 inches of rainfall occurred during the dry season of 1997 at Orlando-compared to only 30.29 inches during the wet season. In December 1997, a substantial amount of rainfall occurred (12.63 inches); December is normally a dry month, with an average rainfall of 2.09 inches (19312000).

Days with relatively low rainfall occurred frequently in Orange County, yet account for little of the annual accumulation. For example, 50 percent of the days with measurable rainfall at Orlando had $0.2 \mathrm{inch}$ or less total rainfall (fig. 11). These relatively low rainfall days accounted for only about 8 percent of the total rainfall accumulation from 1949-1998. Conversely, days with higher daily rainfall totals, though relatively infrequent, account for a large portion of the total rainfall accumulation. For example, rainfall days with totals greater than 1 inch occurred on about 12 percent of the days with measurable rainfall, yet accounted for more than 50 percent of the total rainfall accumulation.

\section{Streamflow}

Records of daily streamflow were compiled for 13 stations in or adjacent to Orange County (table 6). Measurement of daily streamflow began in the 1930s for three stations. Measurement of streamflow at two stations did not begin until 1973. The streamflow characteristics, including magnitudes and seasonal patterns of streamflow, vary widely among the 13 stations depending on the drainage basin sizes and characteristics.

The variability in historic streamflow data recorded at the 13 stations in Orange County is indicated by the streamflow statistics presented in table 6 . The maximum 1-day streamflow (maximum daily mean streamflow for 1 day), 11,600 cubic feet per second $\left(\mathrm{ft}^{3} / \mathrm{s}\right)$, for these 13 stations was at the St. Johns River near Christmas (table 6)

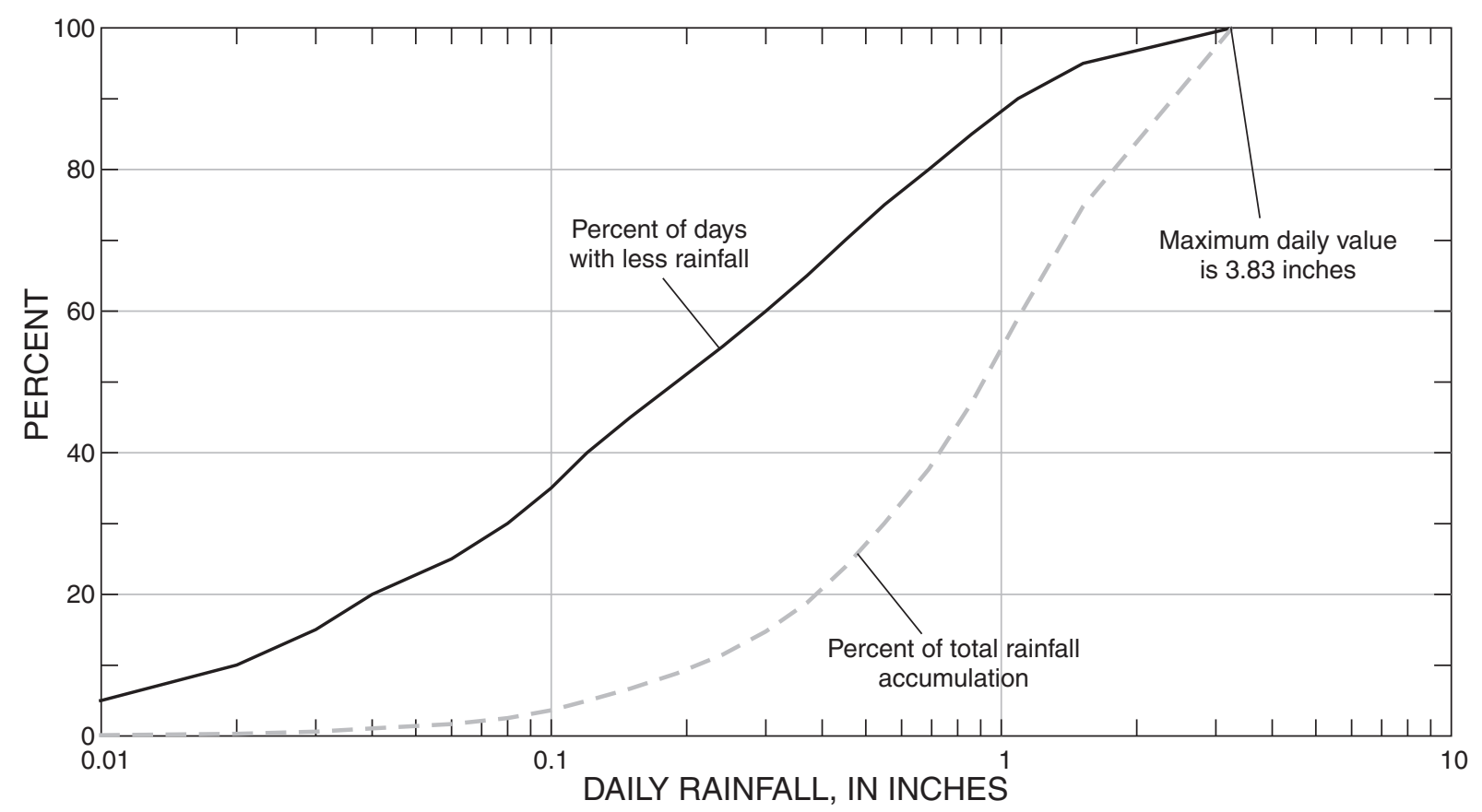

Figure 11. Distribution of daily rainfall at Orlando according to percent of total accumulation and to percent of days with less rainfall, 1949-98. (Days with no rainfall are not included in plot showing percent of days with less rainfall.) 
Table 6. Period of record and annual streamflow statistics for stations in Orange County and adjacent counties.

[Statistics are based on daily mean discharge; drainage area is in square miles; flow is in cubic feet per second; median runoff is in inches per year]

\begin{tabular}{|c|c|c|c|c|c|c|c|c|c|c|c|c|c|}
\hline \multirow{2}{*}{ Station name } & \multirow{2}{*}{$\begin{array}{l}\text { USGS } \\
\text { identifier }\end{array}$} & \multirow{2}{*}{$\begin{array}{l}\text { Period } \\
\text { of } \\
\text { record }\end{array}$} & \multirow{2}{*}{$\begin{array}{c}\text { Total } \\
\text { drainage } \\
\text { area }\end{array}$} & \multicolumn{3}{|c|}{ Annual 1-day high flow } & \multicolumn{3}{|c|}{ Annual 7-day low flow } & \multicolumn{3}{|c|}{ Annual daily flow } & \multirow{2}{*}{$\begin{array}{c}\text { Annua } \\
\text { mediar } \\
\text { runoff }\end{array}$} \\
\hline & & & & $\begin{array}{l}\text { Mini- } \\
\text { mum }\end{array}$ & Median & $\begin{array}{l}\text { Max- } \\
\text { imum }\end{array}$ & $\begin{array}{l}\text { Mini- } \\
\text { mum }\end{array}$ & Median & $\begin{array}{l}\text { Max- } \\
\text { imum }\end{array}$ & $\begin{array}{l}\text { Mini- } \\
\text { mum }\end{array}$ & Median & $\begin{array}{l}\text { Max- } \\
\text { imum }\end{array}$ & \\
\hline St. Johns River near Cocoa & 02232400 & $1954-2000$ & 1,330 & 174 & 3,120 & 9,820 & -18 & 88 & 570 & 68 & 944 & 2,800 & 9.6 \\
\hline St. Johns River near Christmas & 02232500 & 1934-2000 & 1,540 & 522 & 4,380 & 11,600 & -82 & 131 & 803 & 104 & 1,190 & 3,430 & 10.5 \\
\hline $\begin{array}{l}\text { Econlockhatchee River at Magnolia } \\
\text { Ranch near Bithlo }\end{array}$ & 02233001 & 1973-2000 & 32.9 & 17 & 202 & 471 & 0 & 0 & .77 & .9 & 27 & 51 & 11.1 \\
\hline $\begin{array}{l}\text { Little Econlockhatchee River near } \\
\text { Union Park }\end{array}$ & 02233200 & $1960-2000$ & 27.1 & 43 & 386 & 1,570 & .2 & 3.7 & 12 & 6.4 & 29 & 62 & 14.5 \\
\hline Econlockhatchee River near Chuluota & 02233500 & 1936-2000 & 241 & 273 & 2,290 & 10,100 & 6.7 & 31 & 74 & 85 & 259 & 726 & 14.9 \\
\hline $\begin{array}{l}\text { Little Wekiva River near Altamonte } \\
\text { Springs }\end{array}$ & 02234990 & $1973-2000$ & 90.7 & 69 & 257 & 638 & .6 & 7.3 & 15.7 & 8.2 & 38 & 68 & 5.6 \\
\hline Wekiva River near Sanford & 02235000 & 1936-2000 & 189 & 260 & 792 & 2,060 & 105 & 191 & 257 & 197 & 279 & 500 & 20 \\
\hline Apopka-Beauclair Canal near Astatula & 02237700 & 1959-1999 & 184 & 25 & 428 & 754 & 0 & 10 & 92 & 10 & 57 & 263 & 4.4 \\
\hline Boggy Creek near Taft & 02262900 & $1960-2000$ & 83.6 & 60 & 470 & 3,400 & .1 & 2.6 & 12 & 14 & 52 & 139 & 8.4 \\
\hline $\begin{array}{l}\text { Shingle Creek at airport near } \\
\text { Kissimmee }\end{array}$ & 02263800 & $1959-2000$ & 89.2 & 82 & 499 & 3,160 & 0 & 7.0 & 31 & 13 & 74 & 163 & 12.0 \\
\hline Cypress Creek at Vineland & 02264000 & $1946-2000$ & 29.3 & 0 & 31 & 276 & 0 & 0 & 5.3 & 0 & 3.4 & 13 & 1.1 \\
\hline Whittenhorse Creek near Vineland & 02266200 & $1967-2000$ & 12.4 & 0 & 22 & 96 & 0 & 0 & 1.4 & 0 & 3.4 & 13 & 3.7 \\
\hline Reedy Creek near Vineland & 02266300 & $1967-2000$ & 84.6 & 54 & 288 & 1,110 & 0 & 6.8 & 18 & 11 & 36 & 107 & 5.9 \\
\hline
\end{tabular}


in 1953. In contrast, no streamflow was recorded for an entire year at Cypress Creek and Whittenhorse Creek (table 6). The minimum 7-day low flows (minimum daily mean for 7 consecutive days) generally were less than $7 \mathrm{ft}^{3} / \mathrm{s}$ at all stations, even in the St. Johns River. The exception is Wekiva River near Sanford, where the 7-day low flow varied between 105 and $257 \mathrm{ft}^{3} / \mathrm{s}$ during the 1936-2000 period. This relatively high 7-day low flow is because of discharge from Wekiva Spring, Rock Springs, and other springs that provide much of the flow in the river. Spring discharge is relatively stable in comparison to surface runoff, and is less affected by drought. Six of the 13 streams had 7-day low flow of $0 \mathrm{ft}^{3} / \mathrm{s}$ some years. Both St. Johns River stations had a reversal of flow direction. The 7-day low flow at St. Johns River near Christmas was $-3 \mathrm{ft}^{3} / \mathrm{s}$ in 1997, $-82 \mathrm{ft}^{3} / \mathrm{s}$ in 1999 , and $-48 \mathrm{ft}^{3} / \mathrm{s}$ in 2000.

Near Cocoa, the 7-day low flow in the St. Johns River was $-18 \mathrm{ft}^{3} / \mathrm{s}$ in 2000 . These reverse flows probably are caused by prevailing winds from a northerly direction during a drought period with little surface runoff. Because of the small slope of the St. Johns River channel, wind can cause significant effects on streamflow. The determination of flow reversals are more reliable because of the advance in acoustic technology equipment, which quantifies negative discharges more accurately than equipment used prior to the late 1980s.

Some differences in basin characteristics can be observed by comparing differences in runoff. Runoff is the median-annual streamflow expressed as an equivalent depth of water over the entire drainage area that results from the median flow for 1 year. Median values of annual mean runoff are given in table 6 . Although these runoff quantities are based on different periods of record for each stream, comparisons of general streamflow characteristics among the 13 streams probably are valid because the length of concurrent record exceeds 25 years in all cases.

Median runoff ranges from about 20 inches per year (in/yr) in the Wekiva River to about $1.1 \mathrm{in} / \mathrm{yr}$ in Cypress Creek (table 6). The runoff for the Wekiva River is substantially higher than any of the 12 other river basins because of the relatively constant spring discharge that sustains the flow in this stream, even during drought conditions. The low runoff for the Cypress Creek basin results from a lack of sustained inflow from ground water from internally drained areas and a relatively large area of lakes within the drainage basin. About $8 \mathrm{mi}^{2}$ of the $32 \mathrm{mi}^{2}$ Cypress Creek basin is composed of lakes, from which evaporation probably removes water more rapidly than from other areas. Other streams with relatively low runoff (less than $5 \mathrm{ft}^{3} / \mathrm{s}$ ) include the Apopka-Beauclair Canal and Whittenhorse Creek. Most of the flow in Apopka-Beau- clair Canal is from Lake Apopka; evaporation from the lake probably results in relatively low runoff into the canal. The Whittenhorse Creek basin contains numerous swampy areas and higher ground that may be internally drained due to the karstic topography. Evaporation from the swampy areas and low runoff from the internally drained areas are factors that probably contribute to the low runoff in Whittenhorse Creek, even though the creek may receive some seepage from rapid infiltration basins (RIBs). The RIBs, located on hills north of Whittenhorse Creek, are operated by the Reedy Creek Improvement District and began receiving reclaimed water in 1991. The RIBs received about 6.7 Mgal/d of reclaimed water in 1995 (O'Reilly, 1998). O'Reilly estimated that about 67 percent of the water applied to the RIBs recharged the Floridan aquifer system, and the remaining 33 percent discharged through the surficial aquifer system to surface-water bodies.

The seasonal pattern of streamflow in Orange County is shown by daily duration hydrographs for selected streams (fig. 12). These hydrographs show the maximum, median, and minimum streamflow for each day of the year for the period of record. Although streamflow varies widely among the six streams for which flows are plotted, there are, nevertheless, some common characteristics. For example, median daily flows tend to reach maximum values August through November, corresponding to the end of the wet season. Minimum daily streamflow generally is lowest in June, after the dry season has ended and before the onset of the wet season has become effective in increasing runoff to streams. Reedy Creek was dry in April, May, and June of some years. Whittenhorse Creek and Cypress Creek were dry each day of the year in some years. There is less of a pattern in maximum annual streamflows. The occurrence of relatively high streamflows during most seasons demonstrates the effects of an extreme rainfall event, which can occur in any season (although it generally occurs during the summer wet season). This direct runoff is more applicable to smaller drainage area streams than to larger drainage basins, which tend to have peak flows caused by an accumulation of several rainfall events.

\section{Lake Levels}

Water levels in any lake are a function of the balance between components of the lake water budget. Inputs to a lake are from direct rainfall, surface runoff, and groundwater seepage. Water losses are from evaporation and in many lakes can include ground-water seepage and surface outflow through streams. Water levels in many lakes in the Orlando metropolitan area are controlled by drainage 


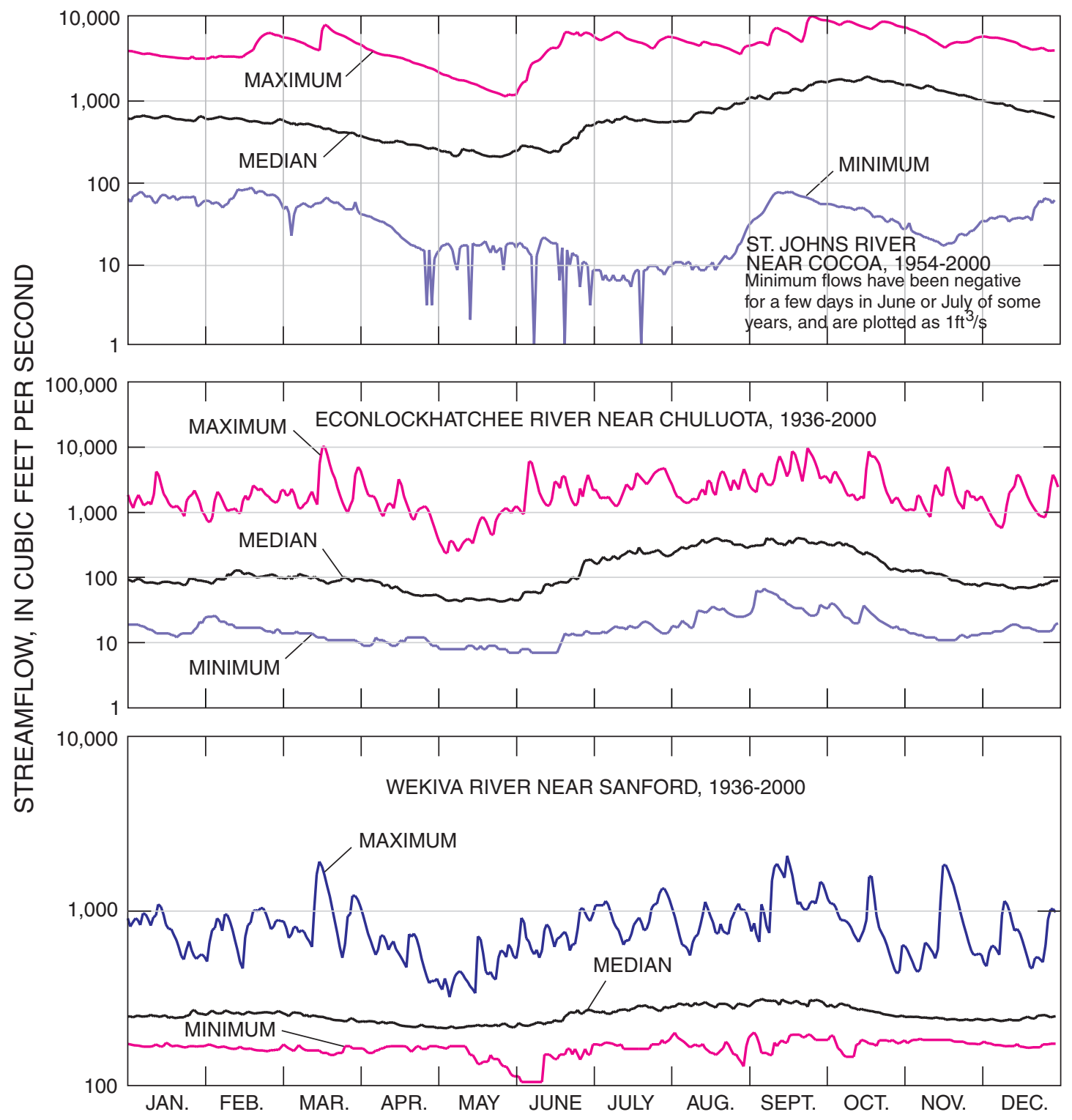

Figure 12. Duration of daily streamflow for selected streams in central Florida.

wells, which direct lake overflow into the Floridan aquifer system. Because rainfall and evaporation are about the same for all lakes over a time period of many years, the large differences in water-level fluctuations among area lakes are due to differences in other components of the water budget. Schiffer (1998) provided a more detailed discussion of lake types and water-level fluctuations.

Eighty-three lakes in or near Orange County have more than 15 years of water-level measurements. For some of the lakes, the record begins in the 1930s (appendix B).

Stage-duration curves for 12 lakes are presented in figure 13. The periods of records are not the same for all the lakes; however, the period of record is probably long enough (at least 35 years) to represent long-term condi- tions at all 12 lakes. Figure 13 shows the large range in lake variability that occurs in Orange County; the range in lake stage was about $13 \mathrm{ft}$ at Lake Francis and Johns Lake, and about $3 \mathrm{ft}$ at Lake Baldwin, Lake Maitland, and Lake Silver.

The variation and seasonal pattern in lake water levels is illustrated by water-level graphs for Lake Silver and Lake Sherwood (fig. 14). Lake Silver (map no. 69 in figure 8 ) is a small urban lake in Orlando that is connected through canals and other lakes to Lake Fairview. The water level in Lake Silver is relatively stable compared to other lakes in Orange County, with a maximum and minimum water level that differs by less than $3 \mathrm{ft}$ during 1960-97. The median monthly water levels vary from about $91.8 \mathrm{ft}$ 


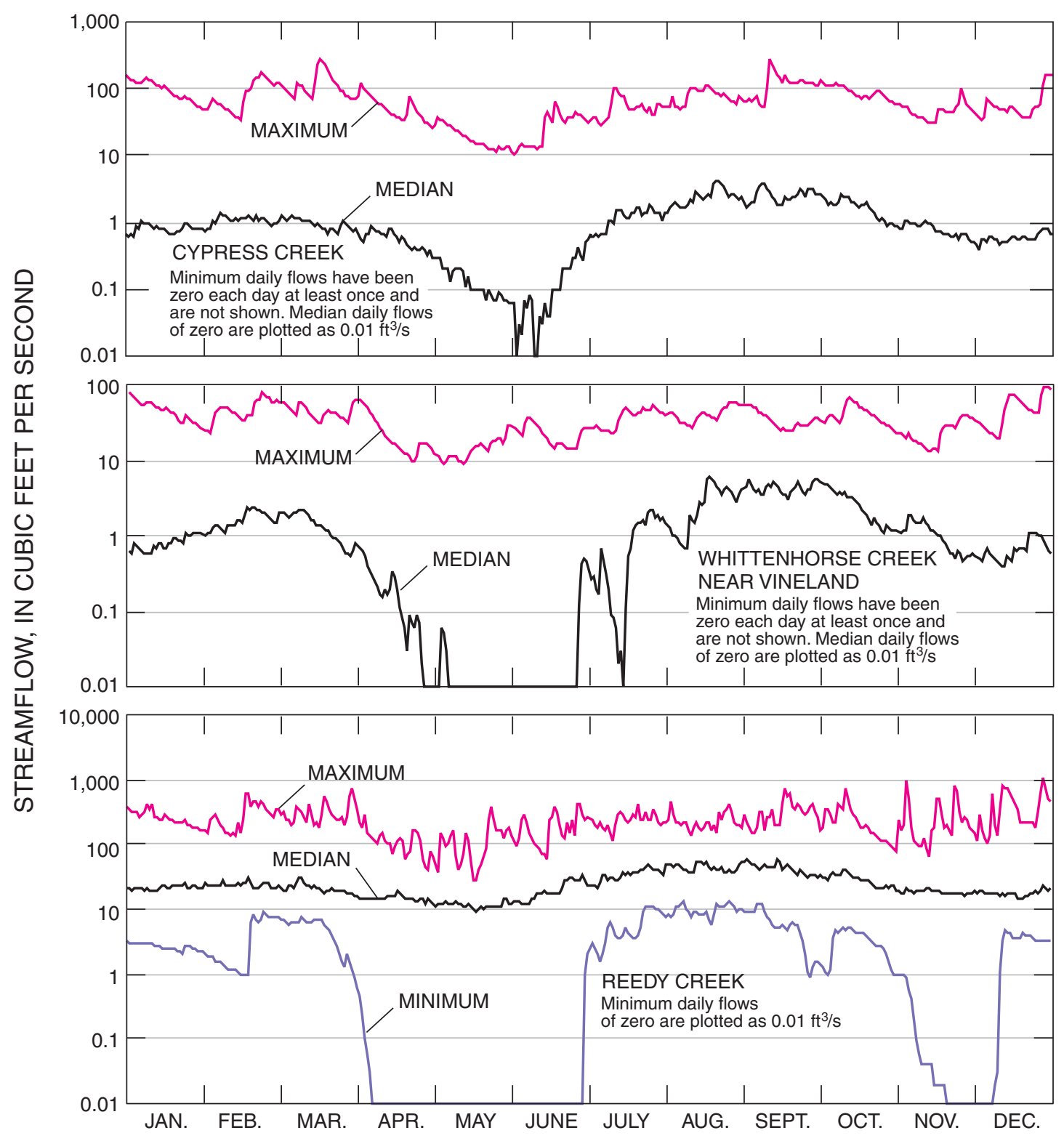

Figure 12. Duration of daily streamflow for selected streams in central Florida. (Continued)

in December to $92.1 \mathrm{ft}$ in July, indicating a small seasonal fluctuation in water level. By contrast, water levels in Lake Sherwood (map no. 68 in figure 8) have a larger range (more than $30 \mathrm{ft}$ ).

The outflow seepage rate from Lake Sherwood is dependent on the head difference between the lake and potentiometric surface of the Upper Floridan aquifer, and at times becomes so large in relation to inflow that the lake goes dry. The water-level record summarized for Lake Sherwood (1960-97) indicates that water level has ranged from about $55 \mathrm{ft}$ to nearly $88 \mathrm{ft}$ above NGVD 29 (fig. 14). Despite this large range, monthly water levels indicate only a slight seasonal pattern. Maximum lake levels have been observed in fall (September through December), indicating that the highest water levels generally follow the summer wet period. Median monthly water levels range from $64.3 \mathrm{ft}$ for June and $66.4 \mathrm{ft}$ for November, a range that is low in comparison to the range in water levels that has occurred during the period of record. This lack of a pronounced seasonal variation in water level is due to the storage capacity of Lake Sherwood. Once filled to a high-water level during a relatively wet period, lake water levels may drop slowly during several months of low rainfall. A period of several months of low rainfall may be required for lake water levels to return to more typical levels. Conversely, after a period of extended drought, many months of normal or above-normal rainfall are needed to restore the lake to a more typical level. 


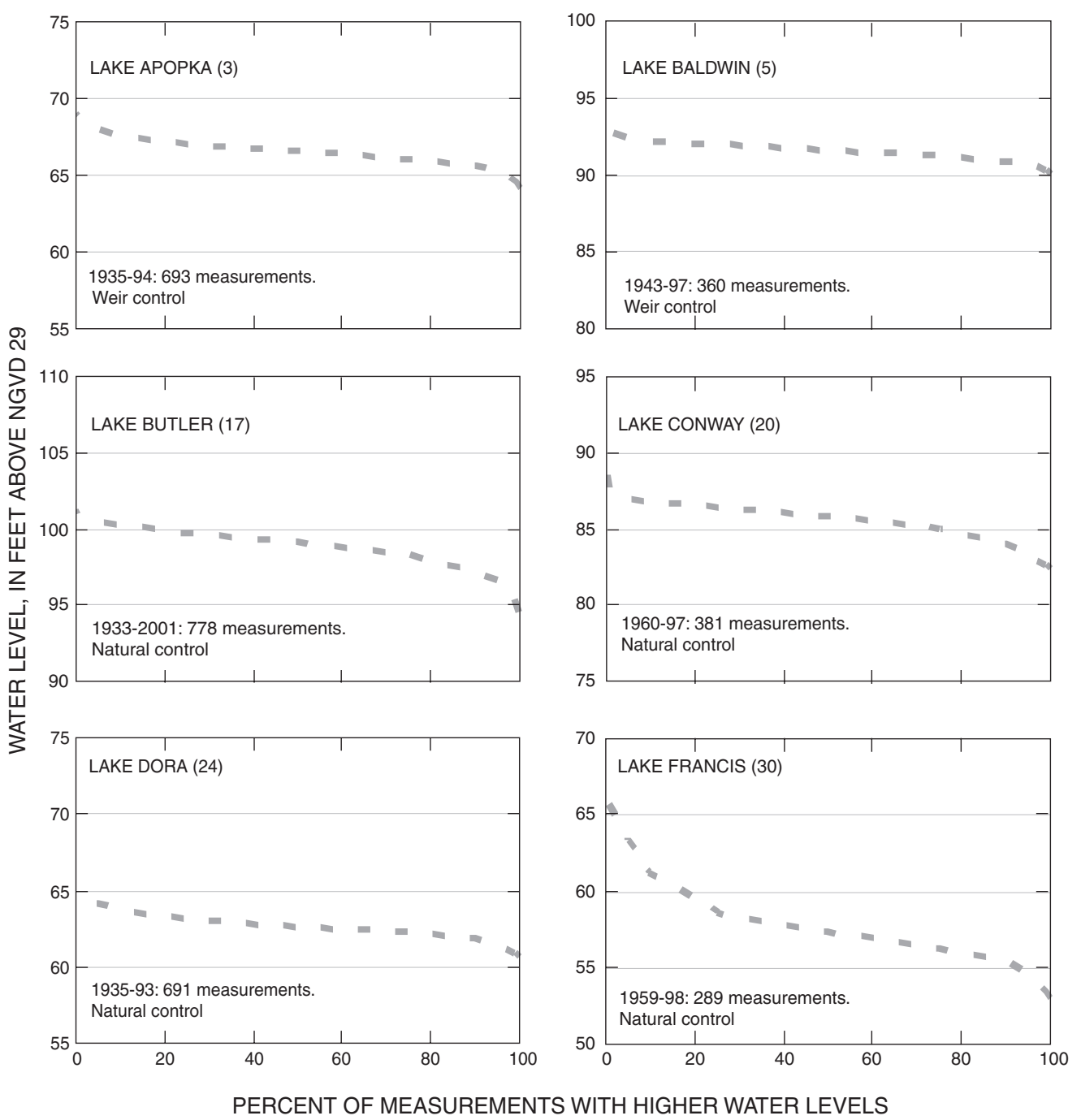

Figure 13. Stage-duration for selected lakes in and around Orange County. (Lake identification number in parentheses after lake name refers to figure 8 and appendix B).

\section{Temporal Trends and Changes}

\section{Precipitation}

The Kendall-Tau test was used to determine if significant temporal trends in annual rainfall at nine stations (fig. 6) occurred. Trend tests were performed for longterm rainfall record (beginning 1931 at some stations) and also for 1970-2000. Discharge records are available for most streamflow stations for 1970-2000 (record at two stations began in 1973, table 6). Significant long-term trends (5-percent significance level) for increasing annual rainfall are indicated at Fort Drum (table 7). The Melbourne station has a significant trend of increasing annual rainfall totals for 1970-2000. These stations are in the upper part of the St. Johns River basin, and are not located in or adjacent to Orange County.

Total annual rainfall at Orlando has a slight cyclical pattern as depicted by the locally weighted scatterplot smoothing (LOWESS) curve fitted to the data (fig. 15). The LOWESS curve indicates a tendency for slightly higher than average rainfall during 1940-65, and lower than average rainfall from about 1966-85. After about 1985, rainfall totals increased to levels characteristic of the 1940-50 period. The plot of 5-year moving average rainfall and the LOWESS fit show this pattern of rainfall variation more clearly (fig. 15). Although the cyclic variation in rainfall is small compared with year-to-year variation, these cyclic variations could have subtle effects on streamflow or lake levels. The effects may be more notable for lakes, which probably have a longer "memory" of anecedent rainfall than for streams. Thus, lake water levels may tend to follow a temporal pattern similar to the pattern indicated by the 5-year moving average rainfall if other factors affecting lake water levels have relatively small impacts. 

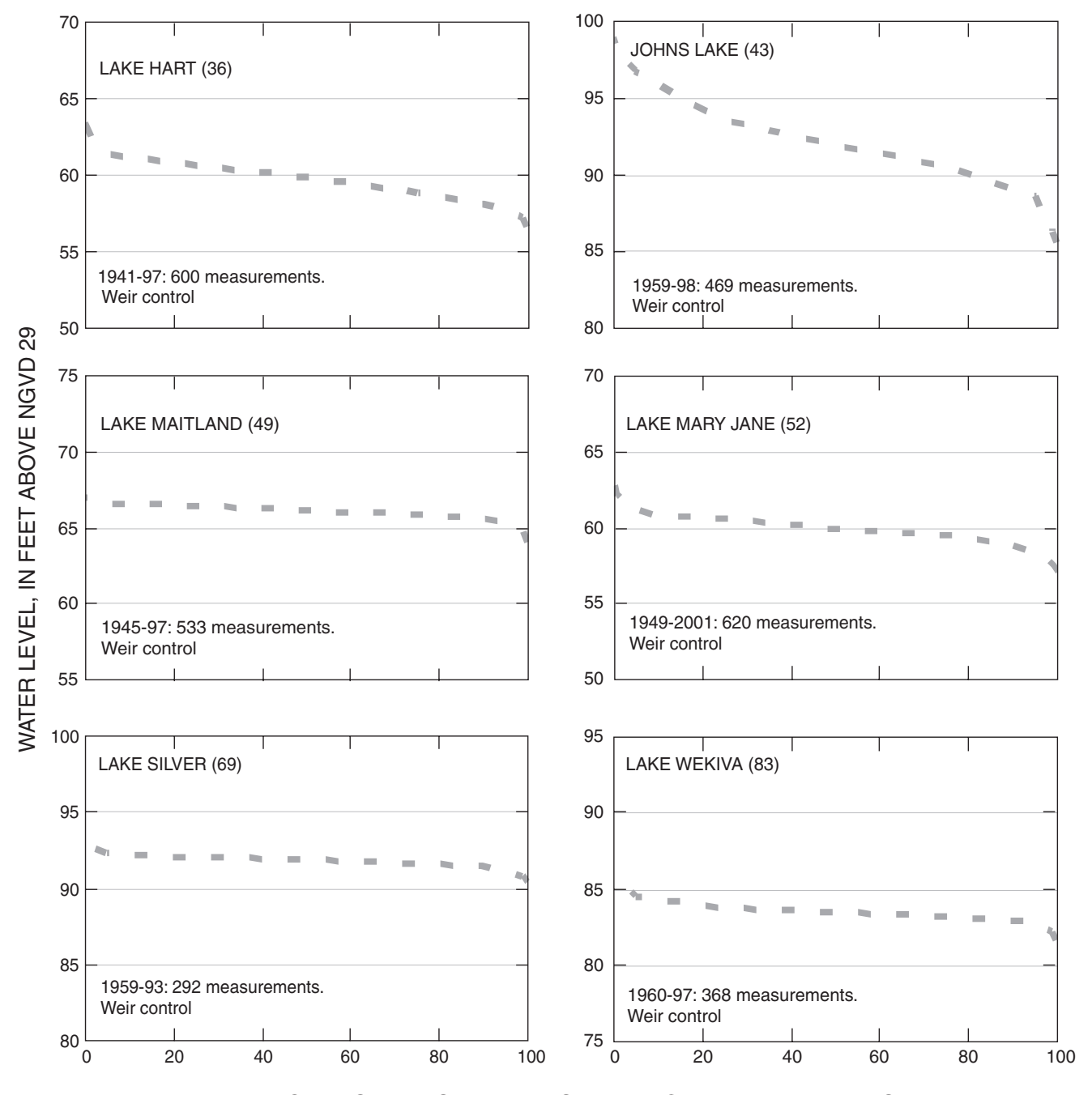

PERCENT OF MEASUREMENTS WITH HIGHER WATER LEVELS

Figure 13. Stage-duration for selected lakes in and around Orange County. (Lake identification number in parentheses after lake name refers to figure 8 and appendix B). (Continued)

\section{Streamflow}

Selected streamflow characteristics computed on an annual basis for 13 stations were examined statistically for temporal trends using the Kendall Tau test. Results of the trend testing indicate changes in annual mean streamflow, 1-day high streamflow, or 7-day low streamflow at 9 of the 13 stations. However, changes in 7-day low streamflow are more common than changes in annual mean or 1-day high streamflow. Changes in low-streamflow characteristics are related to changes in factors controlling streamflow during dry periods, such as spring inflow, ground-water seepage, and wastewater discharge.

Changes in mean and high streamflow characteristics are related to factors affecting larger sources of inflow, such as storm runoff or changes in quantities of wastewater discharge that are large in comparison to the mean streamflow. Basin changes may affect magnitudes of some streamflow characteristics and not affect others.

\section{Low-Flow Characteristics}

There were significant temporal trends in 7-day low streamflow at 7 of the 13 streamflow stations: Little Econlockhatchee River, Econlockhatchee River near Chuluota, Little Wekiva River, Wekiva River, Boggy Creek, Whittenhorse Creek, and Reedy Creek (table 8). In most of these streams, 7-day low streamflows have significantly increased with time.

The 7-day low flow in Shingle Creek does not have a monotonic temporal trend that is detectable by the Kendall Tau test, but the low flows at this site have changed significantly with time (fig. 16). The 7-day low flows 


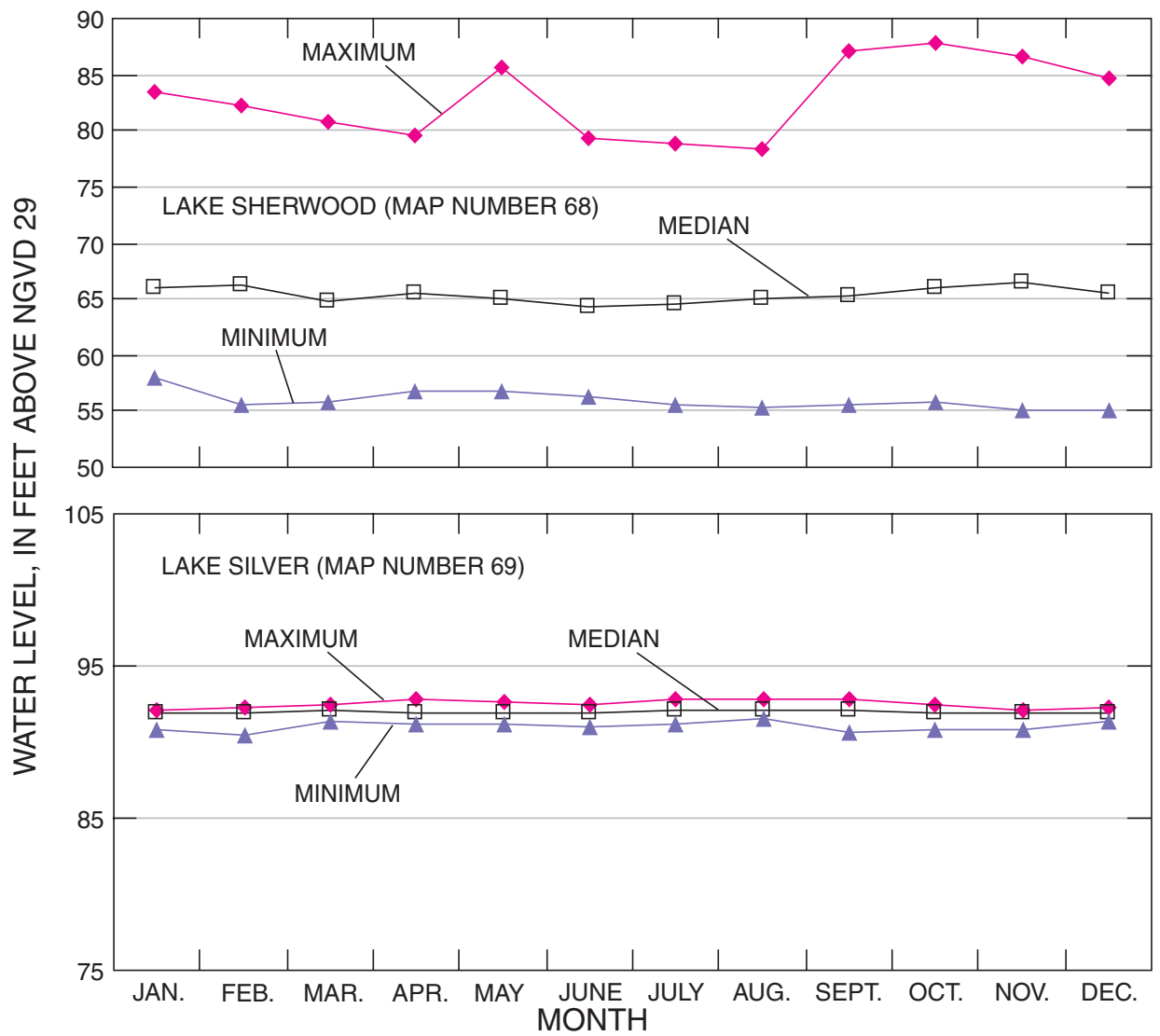

(Period of record is January 1960 through December 1997. Frequency of measurement is monthly or less. Map number refers to figure 8 and Appendix B).

Figure 14. Maximum, median, and minimum water levels by month for Lake Sherwood and Lake Silver.

generally were less than $5 \mathrm{ft}^{3} / \mathrm{s}$ until 1972 , when there was a marked increase to about $11 \mathrm{ft}^{3} / \mathrm{s}$ because of treated wastewater discharged into the creek. As the population served by the wastewater plant discharging into Shingle Creek increased, the wastewater discharge, and consequently, the low flows in Shingle Creek, generally increased each year to a maximum of about $31 \mathrm{ft}^{3} / \mathrm{s}$ in 1984. Redirection of the wastewater from Shingle Creek to RIBs and irrigation areas in west Orange County and Lake County resulted in a pattern of decreasing flow from 1984-89, when redirection of the wastewater discharge was complete. After 1989, the 7-day low flows generally were less than $10 \mathrm{ft}^{3} / \mathrm{s}$. Nonetheless, the graph of 7-day low flows for Shingle Creek (fig. 16) suggests that low flows since 1989 have tended to be greater than low flows before 1972, although near-zero flows have occurred in both periods.

There was a significant decrease in 7-day low streamflows in the Little Wekiva River near Altamonte Springs (table 8). However, this downward trend in 7-day low streamflow is apparent only since about 1986 (fig. 16).
Table 7. Temporal trends in annual rainfall totals at sites in the vicinity of Orange County.

[The Kendall's Tau is a test statistic based on the relation of annual rainfall total with year. A positive tau indicates an increase in rainfall with time, and a negative tau indicates a decrease in rainfall with time. The $p$-value is the probability that a pattern of increasing or decreasing rainfall could result from a trendless set of data. A p-value of 0.05 or less is taken as evidence of a significant trend in rainfall and is in bold type]

\begin{tabular}{|c|c|c|c|c|c|}
\hline \multirow{2}{*}{ Location } & \multirow{2}{*}{$\begin{array}{l}\text { Period of } \\
\text { record }\end{array}$} & \multicolumn{2}{|c|}{ Period of record } & \multicolumn{2}{|c|}{$1970-2000$} \\
\hline & & $\begin{array}{c}\text { Kendall's } \\
\text { Tau }\end{array}$ & p-value & $\begin{array}{c}\text { Kendall's } \\
\text { Tau }\end{array}$ & p-value \\
\hline Clermont & $1931-2000$ & -0.02 & 0.80 & -0.06 & 0.65 \\
\hline Fort Drum & $1943-2000$ & .18 & .04 & .23 & .06 \\
\hline Kissimmee & $1931-2000$ & -.03 & .69 & .23 & .06 \\
\hline Melbourne & $1931-2000$ & -.02 & .84 & .33 & $<.01$ \\
\hline Orlando & $1931-2000$ & -.01 & .89 & .16 & .21 \\
\hline Sanford & $1931-2000$ & -.04 & .66 & .00 & .99 \\
\hline Titusville & $1931-2000$ & -.03 & .73 & .04 & .80 \\
\hline Vero Beach & $1931-2000$ & .13 & .16 & .10 & .44 \\
\hline Lisbon & $1959-2000$ & .10 & .37 & .21 & .10 \\
\hline
\end{tabular}



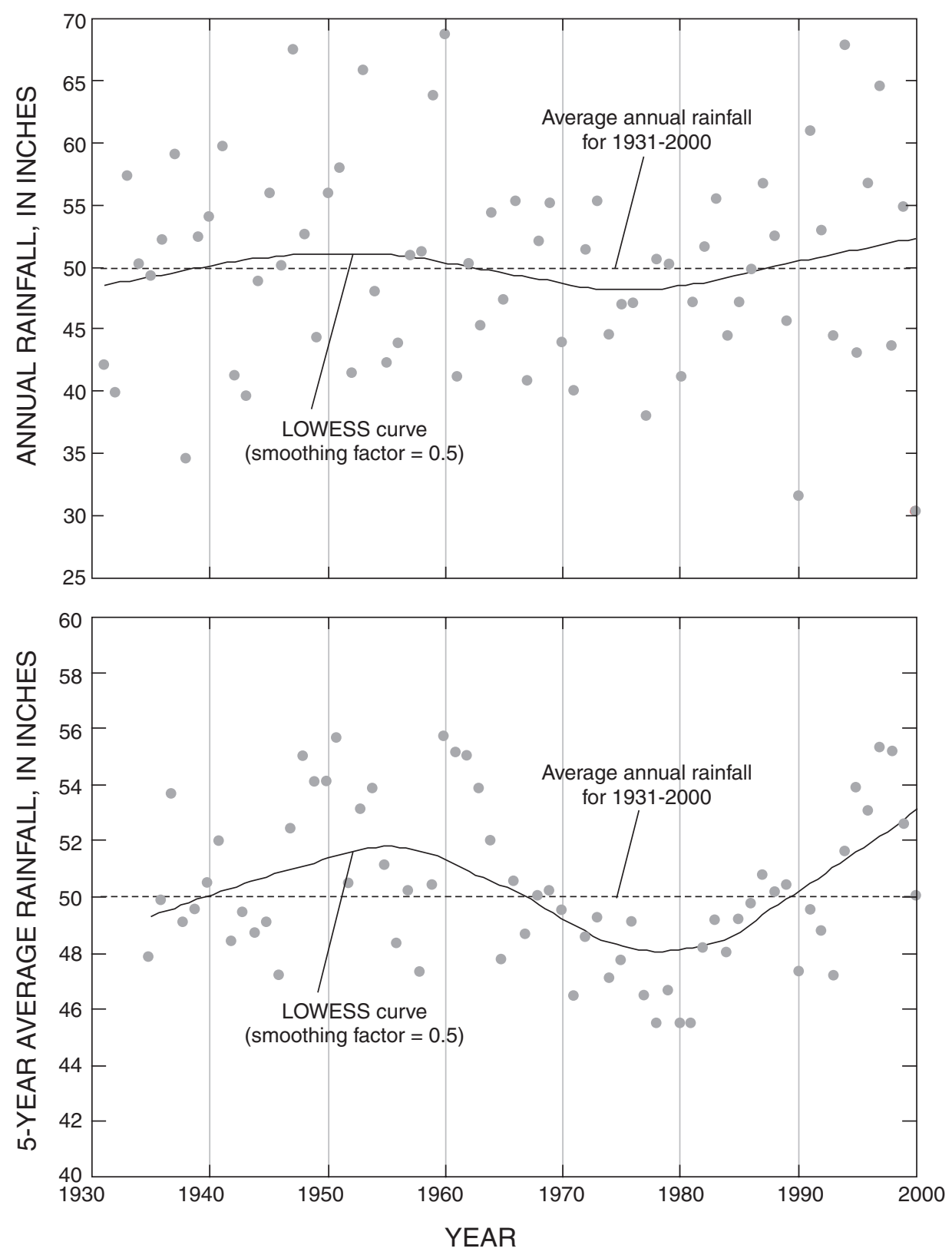

Figure 15. Annual rainfall and 5-year moving average of annual rainfall at Orlando, 1931-2000. (LOWESS: locally weighted scatterplot smoothing)

From beginning of record in 1971 to about 1986, the 7-day low streamflow in the Little Wekiva River appeared to increase. The temporal pattern in low flow in the Little Wekiva River probably is related to discharge of treated wastewater into the stream. As many as seven wastewater treatment plants and a citrus processing plant have discharged into the stream. Currently, however, the Altamonte Springs Wastewater Treatment Plant is the only remaining plant (CDM, 2003); discharge from this plant enters the Little Wekiva River upstream from the gaging station.
The plant began discharging into the river in the mid1970s, and the amount of treated wastewater discharged to the river probably increased with population growth until about the late 1980s when Project Apricot was instituted by the City of Altamonte Springs. Project Apricot is a water re-use plan in which treated wastewater is distributed throughout urban communities in Altamonte Springs for irrigation purposes. As a result of Project Apricot, the quantity of treated wastewater discharged to the Little Wekiva River (not used in Project Apricot) has decreased from an annual average of about $9.6 \mathrm{ft}^{3} / \mathrm{s}$ in 1989 to about 
Table 8. Temporal trends in annual streamflow characteristics at selected sites in the vicinity of Orange County.

[The Kendall Tau is a test statistic based on relation of the annual flow characteristics to time. A positive Kendall Tau value indicates an increase in streamflow with time, and a negative value indicates a decrease in streamflow with time. The $p$-value, given in parentheses, is the probability that a pattern of increasing or decreasing streamflow could result from a trendless set of data due to chance. A probability of 0.05 or less is taken as evidence of a significant trend and is in bold type. See table 6 for period of record]

\begin{tabular}{|c|c|c|c|c|c|}
\hline \multirow{2}{*}{ Station name } & \multirow{2}{*}{$\begin{array}{l}\text { USGS } \\
\text { identifier }\end{array}$} & \multirow{2}{*}{ Years } & \multicolumn{3}{|c|}{$\begin{array}{l}\text { Kendall's Tau and p-value for selected } \\
\text { annual streamflow characteristic }\end{array}$} \\
\hline & & & Mean & 1-day high & 7-day low \\
\hline St. Johns River near Cocoa & 02232400 & 47 & $0.00(1.00)$ & $0.015(0.88)$ & $-0.12(0.24)$ \\
\hline St. Johns River near Christmas & 02232500 & 67 & $-.04(.61)$ & $-.08(.36)$ & $-.04(.65)$ \\
\hline Econlockhatchee River at Magnolia Ranch near Bithlo & 02233001 & 28 & $.26(.05)$ & $.29(.13)$ & $-.07(.65)$ \\
\hline Little Econlockhatchee River near Union Park & 02233200 & 41 & $.27(.01)$ & $.03(.80)$ & $.56(<.01)$ \\
\hline Econlockhatchee River near Chuluota & 02233500 & 65 & $.09(.31)$ & $-.07(.41)$ & $.61(<.01)$ \\
\hline Little Wekiva River near Altamonte Springs & 02234990 & 24 & $.12(.41)$ & $.27(.070$ & $-.46(<.01)$ \\
\hline Wekiva River near Sanford & 02235000 & 65 & $.13(.13)$ & $-.04(.67)$ & $.27(<.01)$ \\
\hline Apopka-Beauclair Canal near Astatula & 02237700 & 41 & $-.09(.41)$ & $-.01(.93)$ & $.09(.40)$ \\
\hline Boggy Creek near Taft & 02262900 & 41 & $.23(.03)$ & $.09(.41)$ & $.25(.02)$ \\
\hline Shingle Creek near Kissimmee & 02263800 & 42 & $.23(.03)$ & $.03(.80)$ & $.17(.12)$ \\
\hline Cypress Creek at Vineland & 02264000 & 55 & $-.08(.41)$ & $-.11(.22)$ & $.03(.77)$ \\
\hline Whittenhorse Creek near Vineland & 02266200 & 34 & $.31(.01)$ & $.26(.03)$ & $.30(.03)$ \\
\hline Reedy Creek near Vineland & 02266300 & 34 & $.30(<.01)$ & $.26(.03)$ & $.44(<.01)$ \\
\hline
\end{tabular}

$0.25 \mathrm{ft}^{3} / \mathrm{s}$ in 2000 (Larry Dolamore, City of Altamonte Springs, written commun., 2004). This decline in discharge of treated wastewater generally corresponds with, and is probably the reason for, the pattern of declining low streamflow in the Little Wekiva River (fig. 16).

Increases in 7-day low-flow are indicated by the Kendall Tau test (table 8) and by plots (fig. 16) of annual 7-day low streamflow for the Little Econlockhatchee River, Econlockhatchee River near Chuluota, Wekiva River, Boggy Creek, Whittenhorse Creek, and Reedy Creek. There is probably no single reason for the increases in 7-day low flows, and for most streams it is difficult to determine definite reasons for the flow increases.

The 7-day low flows in the Little Econlockhatchee River near Union Park (fig. 16) have a pattern of increasing flow since 1960 (beginning of record). The increase was fairly uniform until the mid-1980s; since then, the increase has slowed or stopped altogether, although the year-to-year variation in the low flow apparently has increased. The increases in low streamflow prior to about
1982 may be the result of substantial residential development in the basin. This development included construction and operation of as many as 12 local wastewater treatment facilities that discharged wastewater into the Little Econlockhatchee River in 1982 (Kroening, 2004). The local treatment plants were closed in 1982-84 when the regional Iron Bridge wastewater treatment plant took over wastewater treatment for the areas that had been served by the local plants. Treated wastewater discharge from Iron Bridge is discharged into the Little Econlockhatchee River downstream from the gaging station, and thus, has no effect on streamflow at the gaging station near Union Park. Also, discharges from the local wastewater treatment plants, some of which may have been located upstream of the gaging station, probably did not have a significant effect on streamflow at the Little Econlockhatchee gaging station before 1982. There is no indication that 7-day low streamflow decreased from 1984 on, after all of the local wastewater treatment plants were closed. 

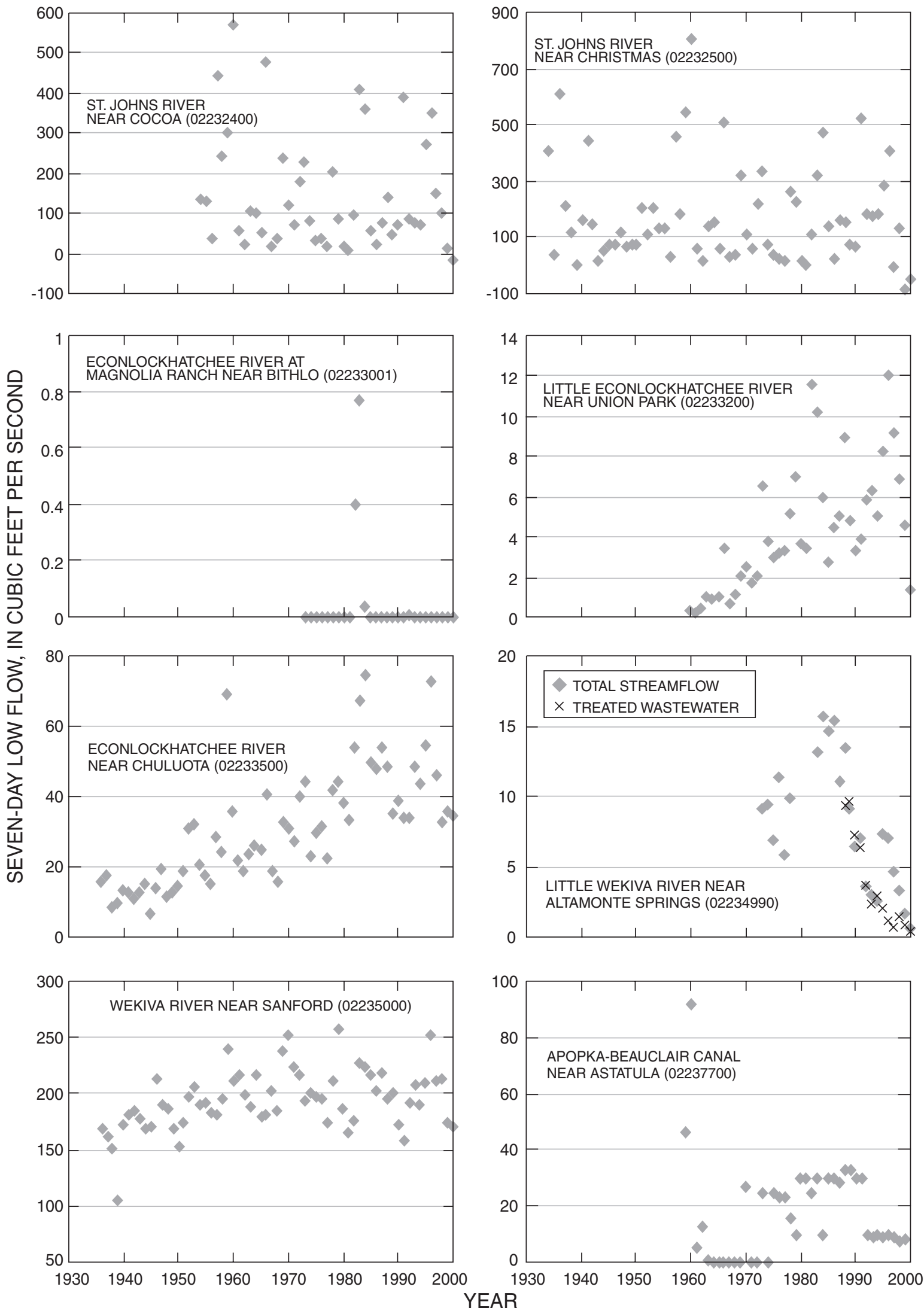

Figure 16. Seven-day low flow for selected streams in or near Orange County, Florida. 

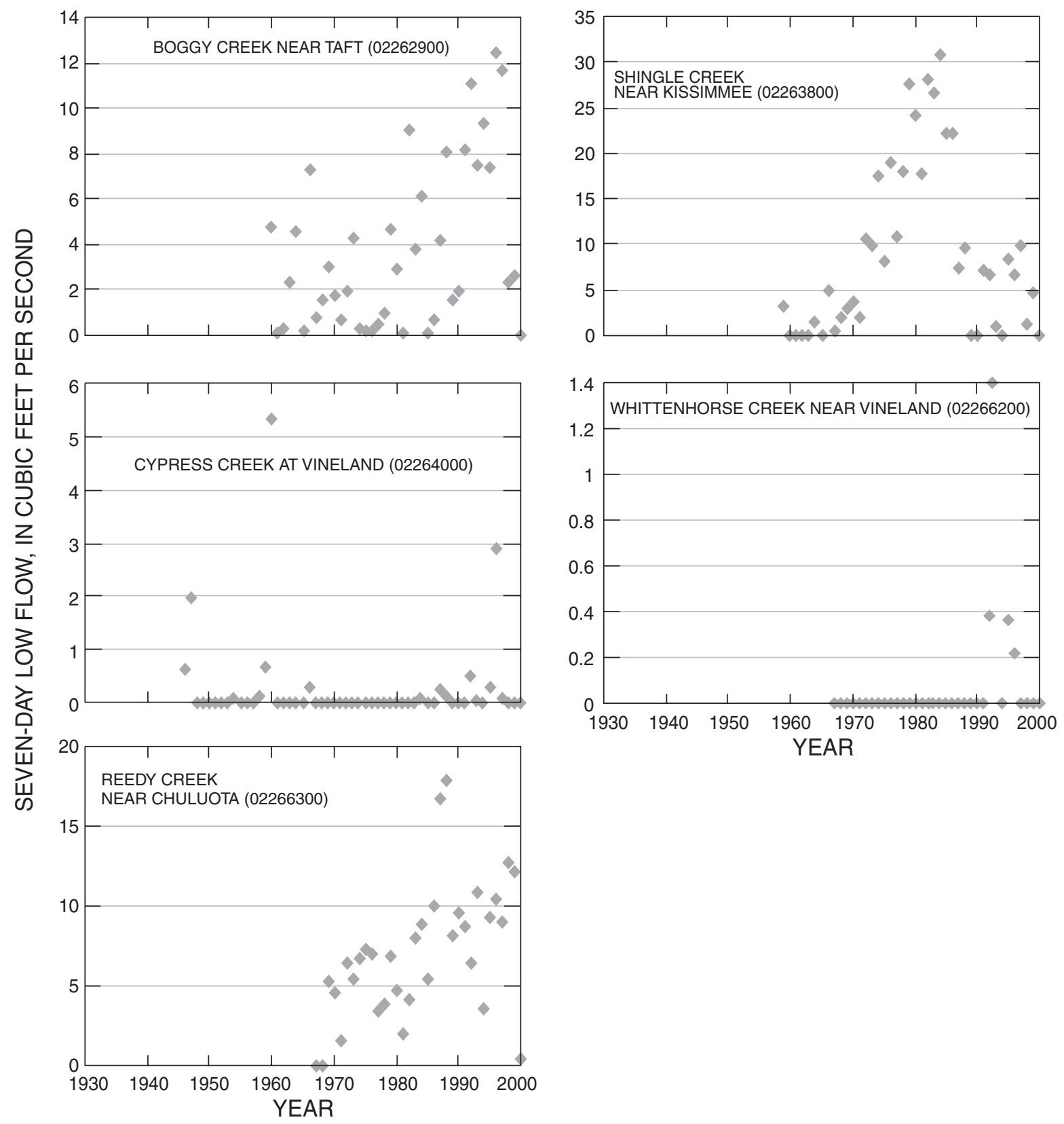

Figure 16. Seven-day low flow for selected streams in or near Orange County, Florida. (Continued)

Major land-use and drainage changes have occurred in the Little Econlockhatchee River basin since the 1960s (Kroening, 2004). These have included channel improvements to the Little Econlockhatchee River and development of a network of drainage ditches to lower the water table and make the land more suitable for residential development. Lowering the water table could result in regional reductions in rates of evapotranspiration (ET). Reducing the ET component of the water budget increases the amount of water available for the other outflow components of the water budget, including seepage and ground-water discharge to streams, which are important in maintaining streamflow during dry periods. Using water from the Floridan aquifer system for irrigation may be another cause of increasing low flows. Runoff of irrigation water, or increased seepage from irrigated areas to streams, could increase base streamflow compared to natural conditions. 
The 7-day low flows in the Econlockhatchee River near Chuluota (fig. 16) have a pattern of increasing flow since 1936 (beginning of record). As in the Little Econlockhatchee River, the increase of low flow in the Econlockhatchee River was fairly uniform until the early or mid-1980s; since then the increase has slowed or stopped altogether, although the year-to-year variation in the low flow apparently has increased. This increased low streamflow is probably the result of increasing wastewater discharge and land drainage associated with residential development. Wastewater discharged into the Little Econlockhatchee River from the local wastewater treatment plants (prior to 1984) and from the regional Iron Bridge wastewater treatment plant (after 1982) enter the Econlockhatchee River upstream from the Chuluota gage.

Wastewater discharge contributes a significant part of the low flow at the Econlockhatchee gaging station near Chuluota. The wastewater discharge was about $30 \mathrm{ft}^{3} / \mathrm{s}$ from 1982-88, and the 7-day low flow at the Econlockhatchee site averaged about $57 \mathrm{ft}^{3} / \mathrm{s}$ for that period (fig. 16). Thus, the wastewater could account for more than one-half of the 7-day low flow during the period 1982-88. In 1989, more than one-half of the wastewater was diverted to an overland wastewater treatment facility that discharges into the St. Johns River. The remaining treated wastewater enters the Econlockhatchee River through the Little Econlockhatchee River. In 2000, wastewater discharge was about $16 \mathrm{ft}^{3} / \mathrm{s}$, or about 46 percent of the 7-day low flow at the Econlockhatchee River near Chuluota (fig. 16).

Low flows in the Wekiva River near Sanford (fig. 16) tended to increase until about 1960, and from then on show no trend. This increase in low flow may be related to basin modifications that began around 1926 (Kroening, 2004) and possible increases in discharge from Wekiva Springs and Rock Springs since about 1960 (Tibbals, 1990). The basin modifications were mostly in the Little Wekiva River basin, and involved construction of drainage ditches for lowering the water table, and extension of the basin by installing water-level control structures on several closedbasin lakes. A possible explanation for increased discharge from the springs since about 1960 is that the springs' vents were flushed of silt and debris during a period of record high discharge in 1960. This flushing could improve the conveyance of the spring vents, and therefore, increase the discharge (Tibbals, 1990).

A pattern of increasing low flow in Boggy Creek near Taft (fig. 16) since 1960 is indicated by the Kendall Tau test. The rate of increase has not been as uniform in Boggy
Creek as in the Econlockhatchee River and the Little Econlockhatchee River, although the hydrographs tend to confirm results of the Kendall Tau test.

The Kendall Tau test indicates a trend of increasing low streamflow in Whittenhorse Creek. However, the plot of annual 7-day low streamflow for Whittenhorse Creek shows only 4 years during the period of record during which the 7-day low streamflow exceeded zero (fig. 16). These nonzero 7-day low streamflows occurred in 1992, 1993, 1995, and 1996. Although these four nonzero low flows may be evidence of an increasing tendency towards nonzero 7-day low flows in Whittenhorse, since 1996 there have been no nonzero 7-day low streamflow, so it seems uncertain that a trend in 7-day low flow exists or is continuing.

Some of the increase in low flow in Reedy Creek (fig. 16) during 1970-90 may be due to the discharge of increasing volumes of treated wastewater to the creek. By 1990, wastewater discharge to Reedy Creek was stopped and was redirected to land-application sites. However, low streamflows in Reedy Creek do not seem to have a downward trend since elimination of the wastewater discharge. The apparent increases in 7-day low flows in Little Econlockhatchee River, Boggy Creek, Reedy Creek since 1990, Shingle Creek since 1989, and the nonwastewater component of the 7-day low flow in the Econlockhatchee River may be related to drainage changes resulting from increased development in Orange County. Development for most purposes, including those as diverse as cattle grazing and residential construction, may involve improvement of surface drainage through stream channelization and construction of canals. These changes in land drainage may lower the water table, resulting in regional reductions in rates of ET. Reducing the ET component of the water budget leaves more water for the other outflow components of the water budget, including seepage and groundwater discharge to streams that is important in maintaining streamflow during dry periods. Using water from the Floridan aquifer system for irrigation may be another cause of increasing low flows in streams. Runoff of irrigation water, or increased seepage from irrigated areas to streams, could increase base streamflow compared to natural conditions.

\section{Annual Mean Flow}

Annual mean streamflow is the arithmetic mean of individual daily mean discharges during a year. Meanannual streamflow is the arithmetic mean of annual mean discharges during a specific period. There were increasing 
temporal trends in annual mean streamflow at 6 of the 13 streamflow stations: Econlockhatchee River at Magnolia Ranch near Bithlo, Little Econlockhatchee River, Boggy Creek, Shingle Creek, Whittenhorse Creek, and Reedy Creek (table 8, fig. 17). There are no indications of decreases in annual mean streamflow among the 13 stations.

The plot of annual mean streamflow for the Econlockhatchee River at Magnolia Ranch near Bithlo (fig. 17) does not indicate that a uniform trend in mean streamflow occurred, although the Kendall Tau test indicates a significant temporal trend. The mean-annual streamflow was low in the 1970s and early 1980s compared to meanannual streamflow in the 1990s. However, the data do not clearly indicate if a pattern of increasing mean-annual streamflow is occurring.

The annual mean streamflow in Shingle Creek (fig. 17) seems to have increased during 1960-80, with no apparent trend after about 1980. This pattern in annual means does not resemble the pattern in 7-day low streamflows, which were observed to decrease after 1986 in response to redirection of treated wastewater from the creek (fig. 16). This difference in pattern between the lowflow and mean flow in Shingle Creek probably occurs because the average 7-day low streamflows (about $22 \mathrm{ft}^{3} / \mathrm{s}$ since 1986) are substantially less than the average annual mean streamflow (about $100 \mathrm{ft}^{3} / \mathrm{s}$ since 1986). Thus, changes in wastewater inflow are significant compared to low-flow magnitudes, but are relatively insignificant compared to the annual mean streamflow.

The annual mean streamflow in Boggy Creek, Cypress Creek, and Whittenhorse Creek generally increased with time (table 8, fig. 17). However, for these streams there have been years with relatively high streamflow in early as well as later parts of the record.

Double-mass analysis was used to observe possible changes in the rainfall-streamflow relations that might be due to basin development. In this approach, any effects of varying rainfall on streamflow patterns are minimized to some extent, although these effects might be included if the rainfall-runoff relation is not linear. The analysis was performed by first developing linear regression models for each stream, relating annual mean streamflow to annual rainfall for the period of record. Stepwise regression was used to select the three rainfall stations for which the greatest correlation between annual rainfall and streamflow occurred. Cumulative sums of streamflow estimated from rainfall by the regression models $\left(\mathrm{Q}_{\mathrm{p}}\right)$ were plotted as a function of cumulative sums of actual streamflow (Q) for each year. Changes in the relation between streamflow and rainfall were indicated by a change in slope of the line defined by the plot of $Q_{p}$ as a function of $Q$. An increase in the amount of streamflow relative to the amount estimated from the streamflow-rainfall model resulted in a decreasing slope of the line, or a downturn of the line toward a more horizontal position. Conversely, a decrease in the amount of streamflow relative to the amount estimated from the streamflow-runoff model resulted in an upturn of the line toward a more vertical position.

The regression models are summarized in table 9. The best model relating annual mean streamflow to annual rainfall was for Econlockhatchee River near Bithlo, with a coefficient of determination $\left(R^{2}\right)$ of 0.73 . This coefficient of determination indicates that 73 percent of the variation in annual mean streamflow was accounted for by variation in annual rainfall. In contrast, the poorest model of annual mean streamflow was for the Apopka-Beauclair Canal $\left(\mathrm{R}^{2}=0.29\right)$, indicating that most of the variation in streamflow was due to factors other than rainfall, including flow control at the gated structure. The coefficients of variation (CV) are an indication of the precision of the models in estimating streamflow, and are expressed as the standard deviation of the residuals (difference between model-predicted streamflow and actual streamflow), in percent of the mean streamflow. The CV's ranged from 15 percent in the Wekiva River to more than 100 percent at Cypress Creek.

The double-mass plots indicate that the streamflowrainfall relations may have changed with time for Little Econlockhatchee River, Wekiva River, Apopka-Beauclair Canal, Boggy Creek, Shingle Creek, Whittenhorse Creek, and Reedy Creek. Streamflow increased for a selected rainfall amount at all stations except Apopka-Beauclair Canal (fig. 18). The double-mass analysis supports the Kendall Tau test and plots of annual mean streamflow, indicating that annual mean streamflow has increased in Little Econlockhatchee River, Boggy Creek, Shingle Creek, Whittenhorse Creek, and Reedy Creek. However, for the Apopka-Beauclair Canal, the double-mass plots indicate a decrease in annual mean streamflow relative to rainfall beginning about 1977 . This possible decrease in streamflow in Apopka-Beauclair Canal after 1977 also is indicated by the plot of annual mean streamflow (fig. 17), but is not indicated by the Kendall Tau test.

Although no temporal trend was indicated in annual mean streamflows in the Wekiva River by the Kendall Tau test (table 8), the double-mass plot indicates a change toward greater streamflow in relation to rainfall beginning 

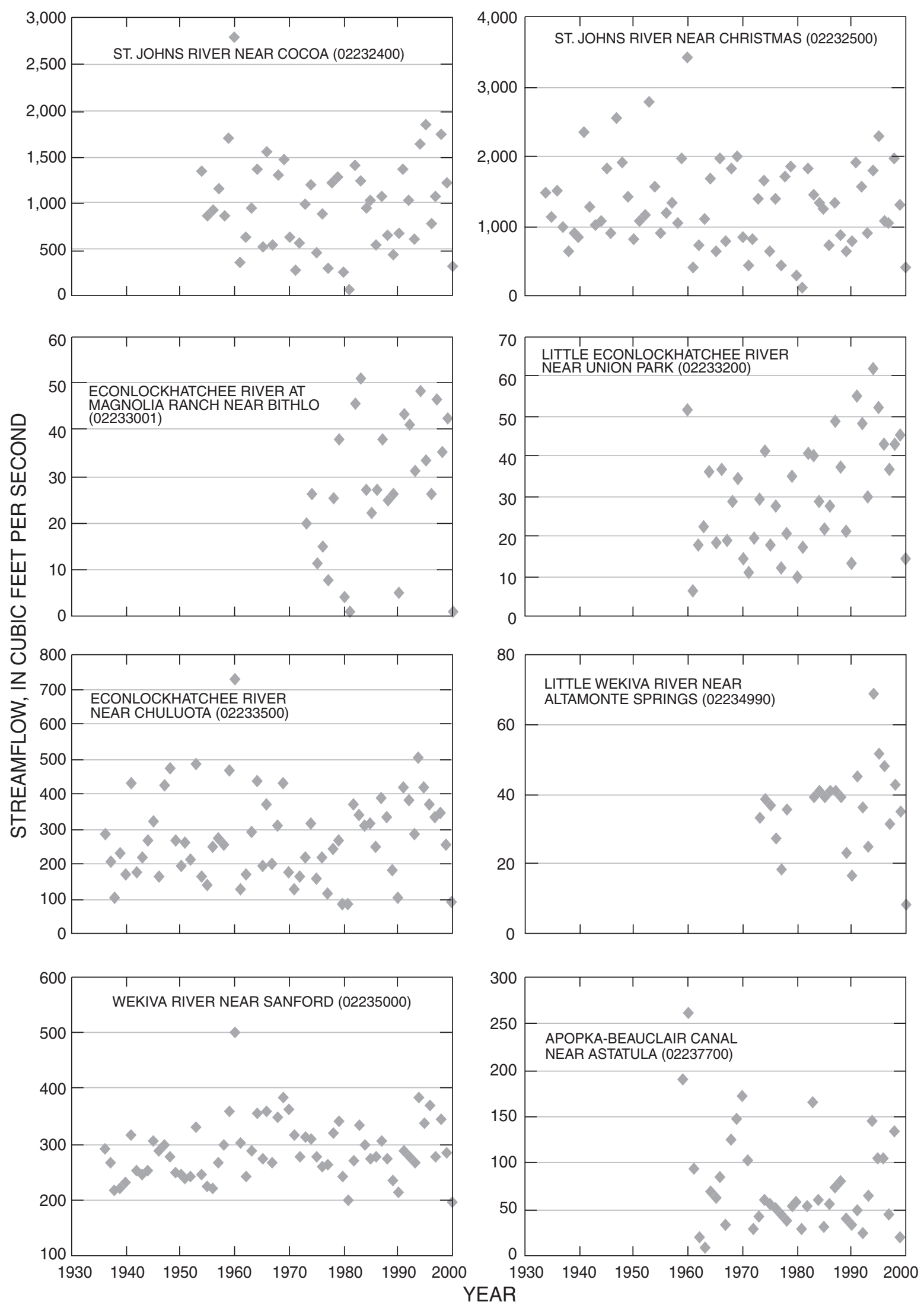

Figure 17. Annual mean streamflow for selected streams in or near Orange County. 

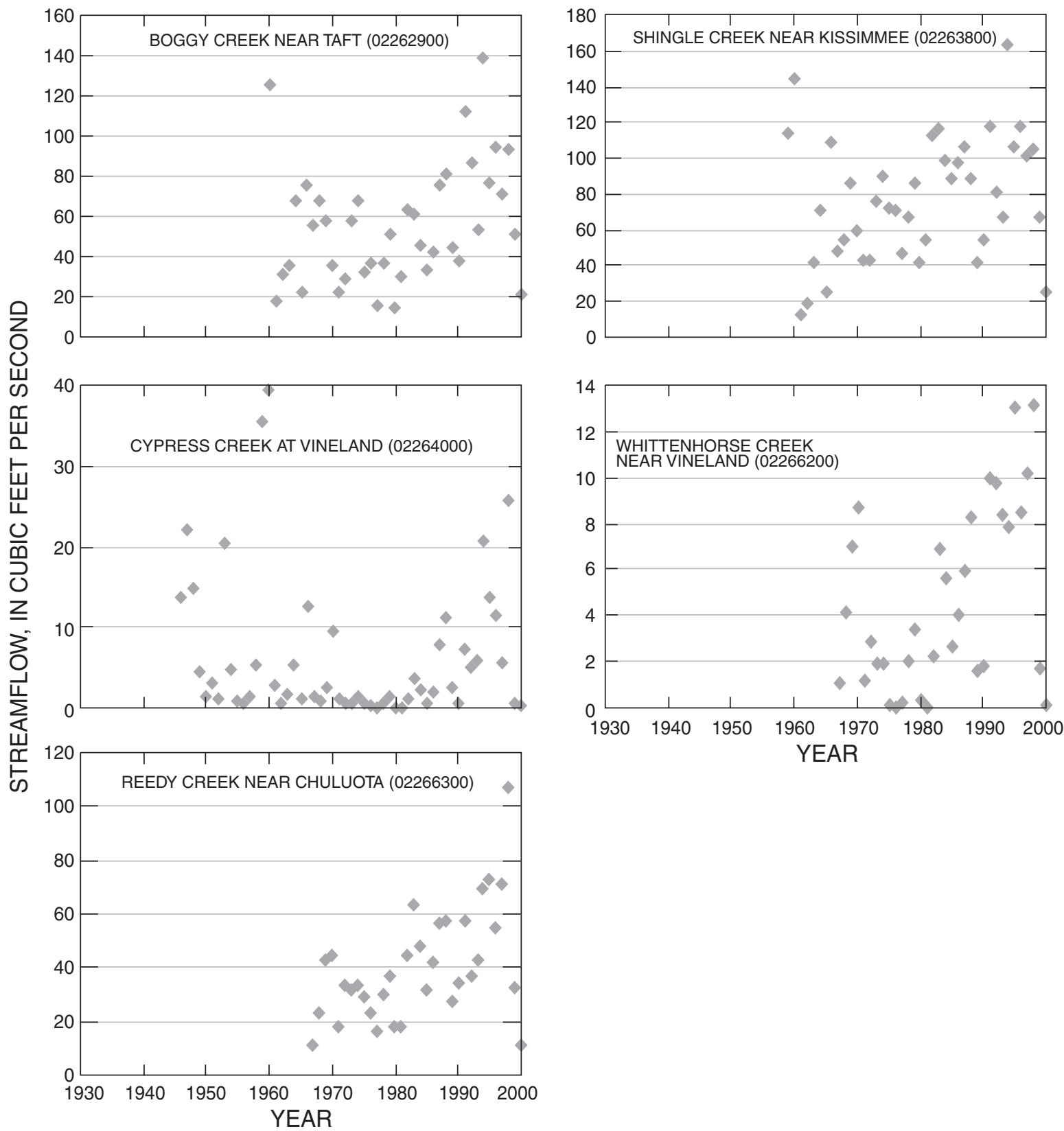

Figure 17. Annual mean streamflow for selected streams in or near Orange County. (Continued)

about 1959 (fig. 18). This increase is not as noticeable from the plot of annual mean streamflow by year, but the plot does indicate a pattern of greater annual mean streamflow after 1959 in the Wekiva River (fig. 17). A comparison of mean-annual streamflow for 1934-1958 $\left(262 \mathrm{ft}^{3} / \mathrm{s}\right)$ with the mean-annual streamflow for 1959-2000 (302 $\mathrm{ft}^{3} / \mathrm{s}$ ) also indicates an increase in annual mean streamflow since about 1959. A possible explanation for increased discharge from the springs since about 1960 is that the springs' vents were flushed of silt and debris during a period of record high discharge in 1960. This flushing could improve the conveyance of the spring vents, and therefore, increase the discharge (Tibbals, 1990).

The double-mass plots for Cypress Creek and Whittenhorse Creek (fig. 18) indicate that relatively abrupt changes in magnitude and direction of slope occurred, but do not indicate clearly whether or not there were persistent changes in streamflow over periods of several years. The large slope changes that occur within a few years may be characteristic of intermittent streams. Both streams 
Table 9. Summary of regression models for estimating annual mean streamflow from annual rainfall.

[Regression model is $0=$ Intercept + Term $_{1}+$ Term $_{2}+$ Term $_{3}$, where 0 is the estimated annual mean streamflow in cubic feet per second, and Term ${ }_{1,2,3}$ are the products of the coefficients listed below and the annual rainfall in inches for the indicated location: mel, Melbourne; orl, Orlando; ver,Vero Beach; san, Sanford; drm, Fort Drum; clr, Clermont; kis, Kissimmee; tvl, Titusville. $\mathrm{R}^{2}$ is the coefficient of determination; CV is the coefficient of variation]

\begin{tabular}{|c|c|c|c|c|c|c|c|c|}
\hline Station name & $\begin{array}{l}\text { USGS } \\
\text { identifier }\end{array}$ & Intercept & \multicolumn{2}{|c|}{ Term $_{1}$} & Term $_{2}$ & Term $_{3}$ & $\mathbf{R}^{2}$ & CV \\
\hline St. Johns River near Cocoa & 02232400 & $-1,482$ & 26.62 & *mel & $10.89 *$ orl & $9.67 *$ ver & 0.65 & 33 \\
\hline St. Johns River near Christmas & 02232500 & $-1,797$ & 32.76 & *mel & $13.78 *$ orl & $14.47 *$ ver & .64 & 32 \\
\hline $\begin{array}{l}\text { Econlockhatchee River at Magnolia Ranch } \\
\text { near Bithlo }\end{array}$ & 02233001 & -54.84 & .4041 & $*$ mel & $.642 *$ orl & $.550 *$ ver & .73 & \\
\hline Little Econlockhatchee River near Union Park & 02233200 & -41.22 & .384 & *mel & $.64 *$ orl & $.378 *$ ver & .65 & 27 \\
\hline Econlockhatchee River near Chuluota & 02233500 & -378.5 & 3.62 & *mel & $6.23 *$ orl & $3.11 *_{\text {ver }}$ & .67 & 28 \\
\hline Little Wekiva River near Altamonte Springs & 02234990 & 62.59 & 1.958 & $* \mathrm{clr}$ & $1.578 * \mathrm{mel}$ & $.958 *$ ver & .42 & \\
\hline Wekiva River near Sanford & 02235000 & 62.59 & 1.96 & $* \mathrm{clr}$ & $1.58 *$ mel & $.958 *$ ver & .42 & 15 \\
\hline Apopka-Beauclair Canal near Astatula & 02237700 & -58.61 & 2.57 & *kis & $1.014 *$ san & $-.792 * t v l$ & .29 & 62 \\
\hline Boggy Creek near Taft & 02262900 & -85.27 & .5596 & $* \mathrm{drm}$ & $1.320 *$ kis & $.933 *$ san & .65 & 32 \\
\hline Shingle Creek near Kissimmee & 02263800 & -85.04 & .910 & *kis & $.930 *$ san & $1.27 *^{*}$ ver & .69 & 25 \\
\hline Cypress Creek at Vineland & 02264000 & -20.84 & .503 & *kis & $.273 *$ mel & $-.210 * \mathrm{tvl}$ & .49 & 105 \\
\hline Whittenhorse Creek near Vineland & 02266200 & -9.818 & .099 & $* \mathrm{drm}$ & $.079 *$ mel & $.104 *$ san & .46 & 65 \\
\hline Reedy Creek near Vineland & 02266300 & -26.23 & -.546 & $* \mathrm{clr}$ & $.971 * \mathrm{drm}$ & $.874 *$ kis & .50 & 38 \\
\hline
\end{tabular}

became dry or nearly dry for 2 to 3 years during periods of low rainfall. Once the basins have dried out, it may take several months of relatively high rainfall to restore flow to the streams. Thus, the streamflow-rainfall relation may change rapidly from periods of no flow to periods of sustained flow.

\section{High-Flow Characteristics}

There were significant increases in 1-day high streamflows in Whittenhorse Creek and Reedy Creek (table 8). Higher flows in these streams generally occurred during 1985-2000 (fig. 19). The reasons for increasing high flows are unclear, but may be related to development and changes in the basins of these streams. Whittenhorse Creek and Reedy Creek are the only streams with temporal trends indicated for each of the flow conditions tested: 7-day low, annual mean, and 1-day high streamflow.

The trend testing (table 8) and data plots (fig 19) do not indicate evidence for changes in 1-day high streamflows in the Little Wekiva River. However, problems associated with stormwater runoff into the river have been documented (Woodward-Clyde Consultants, 1998). These problems are related to decreased stormwater runoff time and increased river flows and velocities, probably as a result of urbanization. The increased flows have caused erosion problems in Orange County and sedimen- tation problems in Seminole County. Buildup of sediments has contributed to flooding and has degraded water quality in both the Little Wekiva River and the Wekiva River.

\section{Lake Water Levels}

Trends in lake water levels were evaluated from estimated annual mean water levels. The annual mean water levels were determined from periodic water-level measurements by averaging all water level measurements for each year. Years with less than four water-level measurements were not included in the analysis. Temporal trends were only determined for lakes with more than 15 years of record. Two sets of tests were performed. One set of trend tests was completed using the entire period of record at each lake. Because the periods of water-level record varied widely among the lakes, another set of tests was performed for 1970-97. This test included only lakes with record of water level during the entire 1970-97 period, and was used to compare effects of lake type and location on water-level changes during a period common to all lakes included in the analysis.

Interpretation of the statistical trend testing is limited because of the characteristics of the data base, and also because the tests do not consider multiple trends that may occur within the test period. The data base of lake levels is not ideal for comparison of trend-test results among the 

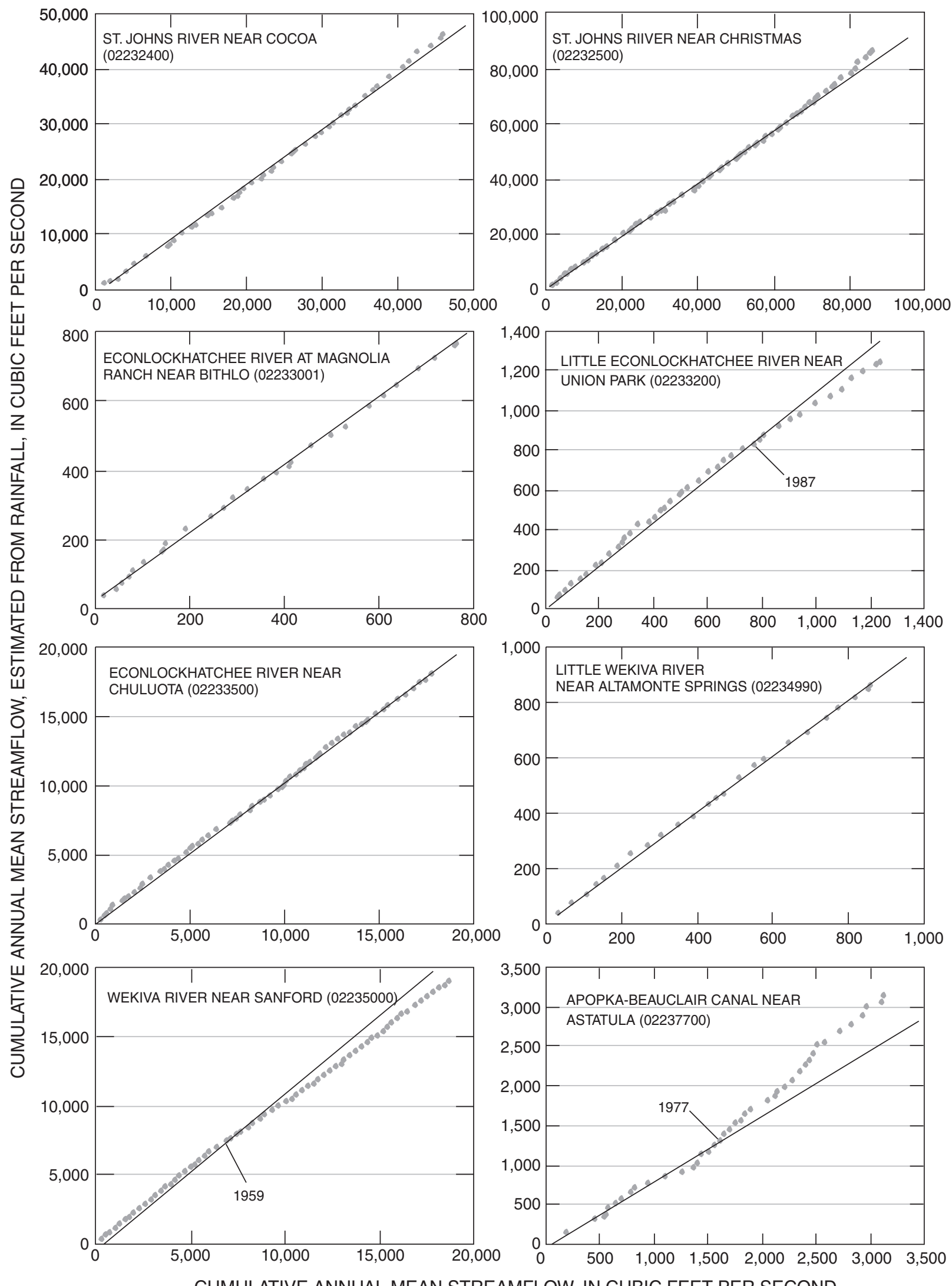

Figure 18. Streamflow for selected streams in or near Orange County. (Points are cumulative annual mean and cumulative annual mean estimated from rainfall. The solid line is hand-fitted to show year when slope of cumulative plot changed.) 

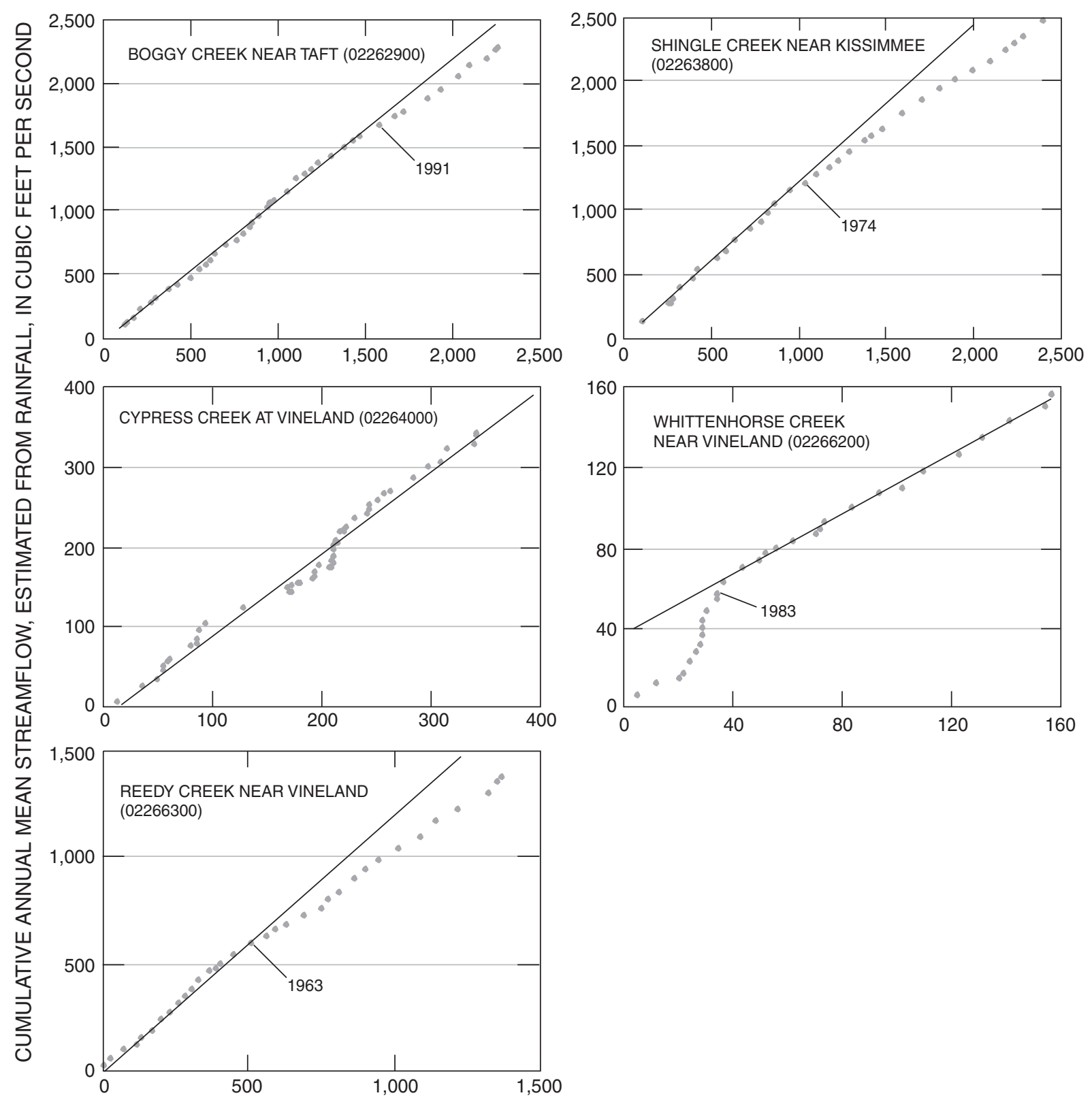

CUMULATIVE ANNUAL MEAN STREAMFLOW, IN CUBIC FEET PER SECOND

Figure 18. Streamflow for selected streams in or near Orange County. (Points are cumulative annual mean and cumulative annual mean estimated from rainfall. The solid line is hand-fitted to show year when slope of cumulative plot changed.) (Continued)

lakes because of the nonuniformity of period of record and frequency of water-level measurement. Some lakes were measured monthly or more often, and other lakes had quarterly or fewer measurements some years. In some lakes, there were downward trends in water level for several years, followed by upward trends. In these cases of multiple trends within a period of lake data, the statistical test result will apply only to the overall tendency for waterlevel change over the entire test period and provides no insight regarding short-term trends. In spite of these limitations in trend-test application, some general conclusions can be made regarding trends of lakes water level.

A total of 83 lakes had more than 15 years of record; in some cases the record began in the 1930s. There were significant temporal trends in 33 of the 83 lakes ( 40 percent) tested using the entire period of record (table 10). Of these 33 lakes, 14 had increasing water levels and 19 lakes had decreasing water levels. 
Hydrology and Water Quality of Lakes and Streams in Orange County, Florida
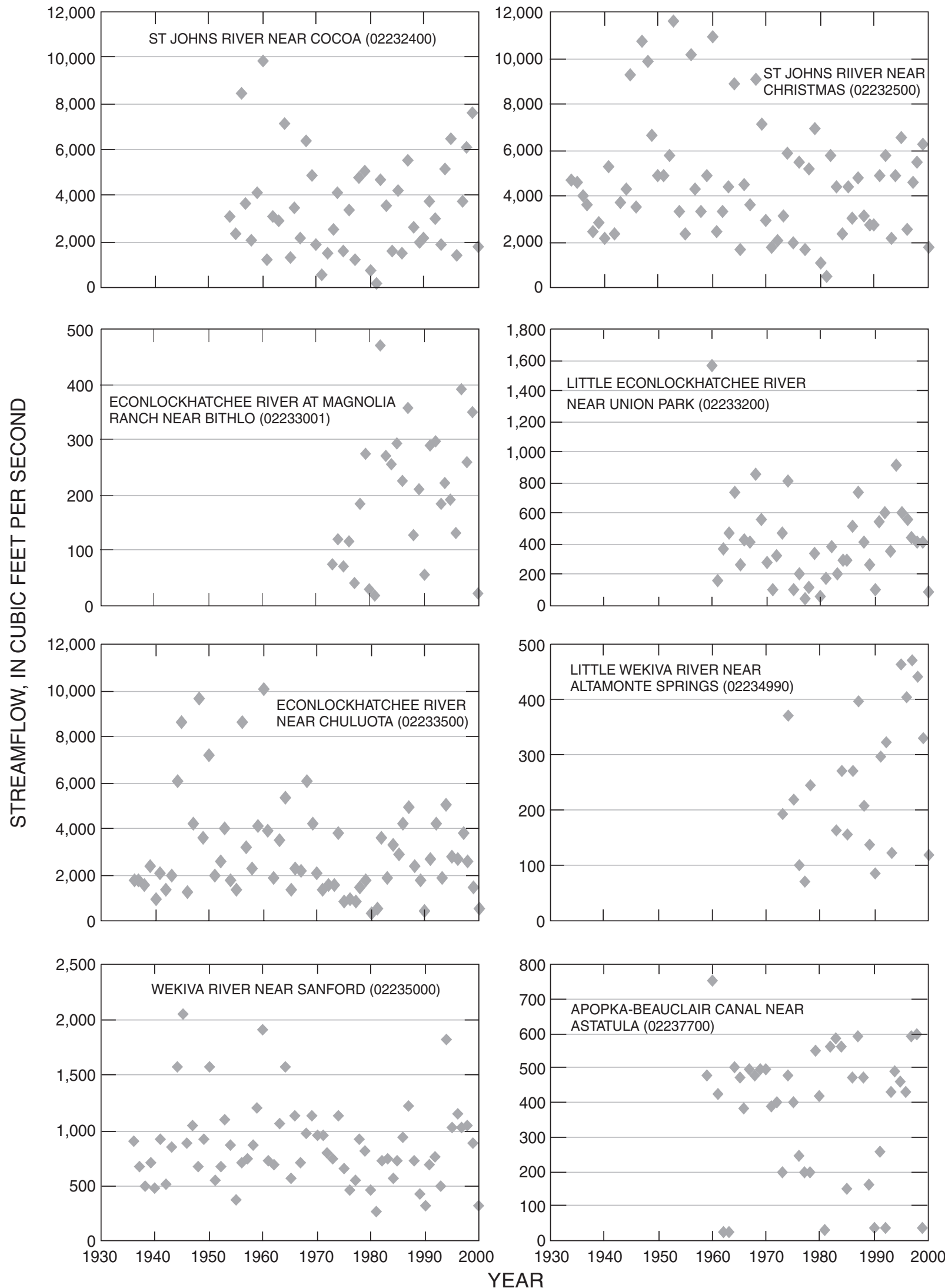

Figure 19. One-day high flow for selected streams in or near Orange County. 


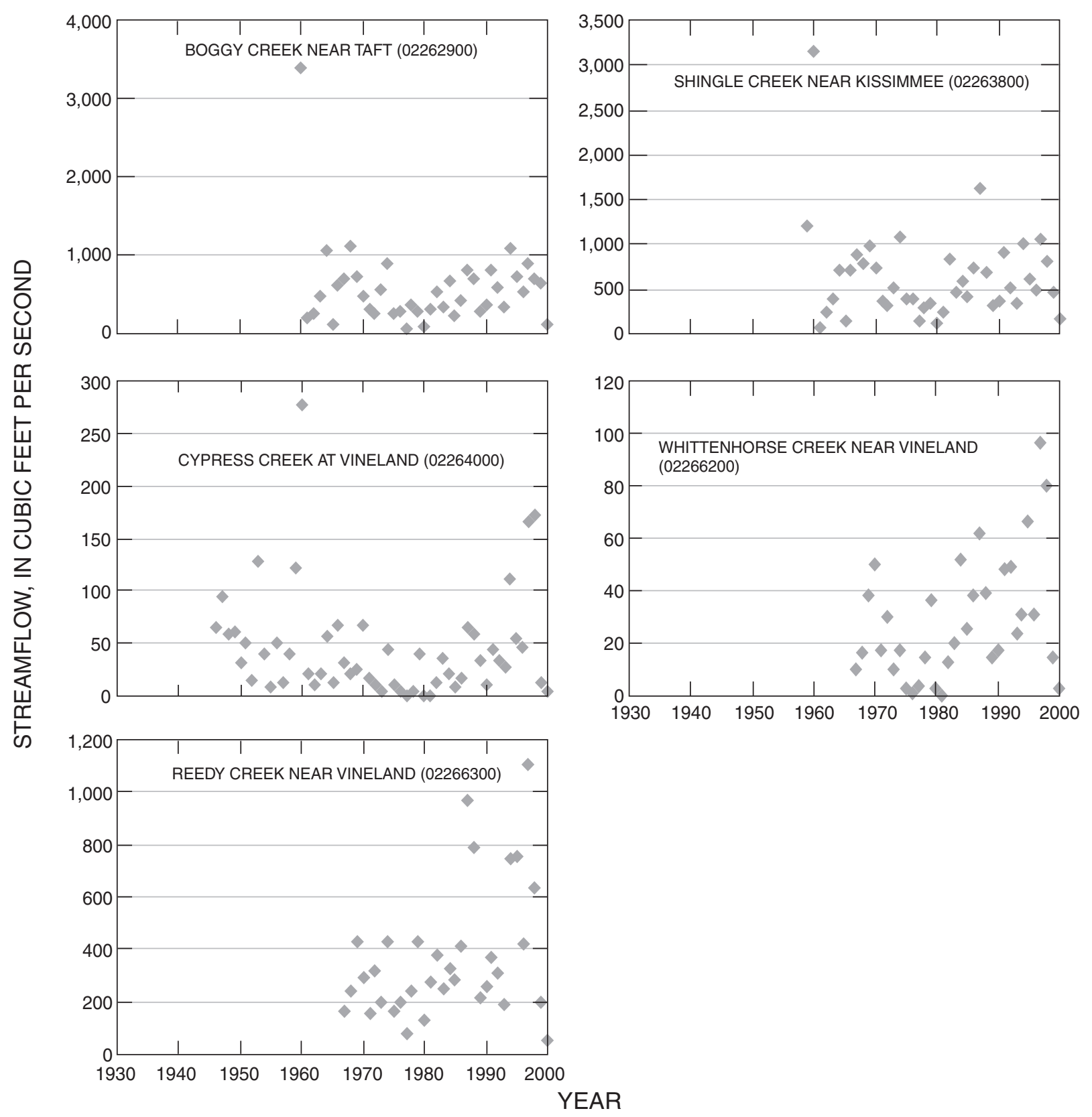

Figure 19. One-day high flow for selected streams in or near Orange County. (Continued)

More than one-half of the lakes with significant trends for the entire period of water-level record had declining water levels. The reason for this predominance of downward trends in long-term record may be that extreme highwater conditions existed for many lakes in 1960 after 2 years of relatively high rainfall_culminated by rains from Hurricane Donna in September 1960. For Orlando, rainfall totals were 63.9 inches in 1959 and 68.7 inches in 1960. At Kissimmee, rainfall totals were 76.7 inches in
1959 and 80.4 inches in 1960. As a result of the high rainfall during these 2 years, historical high-water levels occurred in many lakes in 1960 or 1961 (fig. 20). These high-water levels persisted at least into 1961 at many lakes and likely had an effect on trend testing of the entire period of record for many lakes, especially those in which recordkeeping began in or around 1960. Examples of the significance of the 1959-60 high-rainfall totals on historical high-water levels is especially notable for Lake Alpharetta, 


\section{Hydrology and Water Quality of Lakes and Streams in Orange County, Florida}

Table 10. Results of statistical testing for trends in lake water levels.

[Only lakes with at least 15 years of record are included; annual mean water levels were tested. Type: S, seepage lake; D, lake is part of surface-drainage feature. Control: pump, lake stage can be controlled by pumping; weir, weir control; well, drainage well control; cvt, culvert control, None, no manmade control of water level; <, less than; --, insufficient data for analysis. The Kendall $\mathrm{T}$ is a test statistic based on the relation of annual mean lake level with time. A positive $T$ indicates an increase in lake level with time; a negative $T$ indicates a decrease in lake level with time. The $p$-value is the probability that a pattern of increasing or decreasing water level could result from a trendless set of data. A p-value of 0.05 or less is taken as evidence of a significant trend in water level and is in bold type]

\begin{tabular}{|c|c|c|c|c|c|c|c|c|c|c|c|}
\hline \multirow{2}{*}{ Lake } & \multirow{2}{*}{$\begin{array}{l}\text { Map } \\
\text { No. }\end{array}$} & \multirow{2}{*}{ Type } & \multirow{2}{*}{$\begin{array}{l}\text { Con- } \\
\text { trol }\end{array}$} & \multirow{2}{*}{$\begin{array}{l}\text { Township } \\
\text { (South) }\end{array}$} & \multirow{2}{*}{$\begin{array}{l}\text { Range } \\
\text { (East) }\end{array}$} & \multicolumn{3}{|c|}{$1970-1997$} & \multicolumn{3}{|c|}{ Period of record } \\
\hline & & & & & & Years & Kendall T & Probability & Years & Kendall T & Probability \\
\hline Alpharetta & 1 & $\mathrm{~S}$ & none & 21 & 28 & 21 & -0.32 & 0.04 & 31 & -0.5 & $<0.01$ \\
\hline Anderson & 2 & $\mathrm{~S}$ & pump & 23 & 30 & 23 & .15 & .32 & 26 & -.08 & .55 \\
\hline Apopka & 3 & $\mathrm{D}$ & weir & 22 & 27 & -- & -- & -- & 58 & -.12 & .19 \\
\hline Avalon & 4 & $\mathrm{~S}$ & none & 23 & 27 & 16 & -.20 & .28 & 19 & -.38 & .02 \\
\hline Baldwin & 5 & $\mathrm{D}$ & weir & 22 & 30 & 22 & .19 & .23 & 34 & .04 & .77 \\
\hline Barton (Big) & 6 & $\mathrm{~S}$ & weir & 22 & 30 & 26 & -.13 & .34 & 36 & -.34 & $<.01$ \\
\hline Barton (Little) & 7 & $S$ & well & 22 & 30 & 17 & .07 & .71 & 20 & .21 & .21 \\
\hline Barton Lake & 8 & $\mathrm{D}$ & weir & 24 & 31 & 26 & .47 & $<.01$ & 36 & .38 & $<.01$ \\
\hline Bay & 9 & S & none & 22 & 29 & 22 & .39 & .01 & 24 & .4 & $<.01$ \\
\hline Bearhead & 10 & S & well & 23 & 29 & -- & -- & -- & 17 & -.09 & .62 \\
\hline Bell & 11 & $S$ & $\mathrm{cvt}$ & 22 & 29 & 23 & .31 & .04 & 24 & .31 & .03 \\
\hline Berry & 12 & $\mathrm{D}$ & none & 22 & 30 & 17 & .19 & .28 & 17 & .19 & .28 \\
\hline Big Fairview & 13 & $\mathrm{~S}$ & well & 22 & 29 & 26 & .13 & .32 & 36 & -.05 & .66 \\
\hline Black & 14 & $\mathrm{U}$ & weir & 22 & 27 & -- & -- & -- & 18 & -.22 & .21 \\
\hline Border & 15 & $\mathrm{~S}$ & none & 21 & 28 & -- & -- & -- & 17 & -.34 & .06 \\
\hline Bosse & 16 & $S$ & weir & 21 & 29 & 25 & .41 & $<.01$ & 33 & -.16 & .18 \\
\hline Butler & 17 & $\mathrm{D}$ & none & 23 & 28 & 28 & .35 & $<.01$ & 66 & -.26 & $<.01$ \\
\hline Cane & 18 & $\mathrm{~S}$ & none & 23 & 28 & -- & -- & -- & 18 & -.08 & .62 \\
\hline Clear & 19 & $\mathrm{D}$ & weir & 23 & 29 & 26 & -.03 & .82 & 35 & .18 & .13 \\
\hline Conway & 20 & $S$ & well & 23 & 29 & 26 & .16 & .26 & 44 & .17 & .10 \\
\hline Crescent & 21 & $\mathrm{U}$ & $\mathrm{cvt}$ & 23 & 27 & 18 & .53 & $<.01$ & 22 & .25 & .11 \\
\hline Crooked & 22 & $S$ & none & 22 & 28 & 21 & -.07 & .67 & 30 & .13 & .31 \\
\hline Daniel & 23 & S & none & 22 & 29 & 22 & .28 & .07 & 23 & .34 & .02 \\
\hline Dora & 24 & S & none & $\mathrm{L}$ & & -- & -- & -- & 58 & -.15 & .09 \\
\hline Down & 25 & S & none & 23 & 28 & 22 & .50 & $<.01$ & 26 & .22 & .12 \\
\hline Ellenore & 26 & $\mathrm{D}$ & weir & 23 & 29 & 23 & .64 & $<.01$ & 23 & .66 & $<.01$ \\
\hline Estelle & 27 & $\mathrm{D}$ & well & 22 & 29 & -- & -- & -- & 17 & -.69 & $<.01$ \\
\hline Fish & 28 & $\mathrm{U}$ & none & 24 & 28 & 18 & .56 & $<.01$ & 22 & .26 & .09 \\
\hline Formosa & 29 & $\mathrm{D}$ & well & 22 & 29 & -- & -- & -- & 17 & -.69 & $<.01$ \\
\hline Francis & 30 & $\mathrm{~S}$ & none & $\mathrm{L}$ & & 28 & -.15 & .24 & 40 & -.17 & .12 \\
\hline Fredrica & 31 & $\mathrm{~S}$ & $\mathrm{cvt}$ & 23 & 30 & -- & -- & -- & 18 & -.1 & .57 \\
\hline Gandy & 32 & S & $\mathrm{cvt}$ & 21 & 29 & 25 & .33 & .02 & 34 & -.13 & .28 \\
\hline Gatlin & 33 & $\mathrm{U}$ & weir & 23 & 29 & -- & -- & -- & 22 & .45 & $<.01$ \\
\hline Gem Mary & 34 & $\mathrm{~S}$ & none & 23 & 29 & 19 & .19 & .25 & 22 & .07 & .63 \\
\hline Hancock & 35 & $\mathrm{U}$ & none & 23 & 27 & 19 & .30 & .07 & 22 & .19 & .20 \\
\hline Hart & 36 & $\mathrm{D}$ & weir & 24 & 31 & 26 & .67 & $<.01$ & 54 & .46 & $<.01$ \\
\hline Hickory Nut & 37 & $S$ & none & 24 & 27 & -- & -- & -- & 17 & .43 & .02 \\
\hline Holden & 38 & S & well & 23 & 29 & -- & -- & -- & 22 & .22 & .15 \\
\hline Horseshoe & 39 & $S$ & $\mathrm{cvt}$ & 22 & 28 & -- & -- & -- & 17 & -.29 & .10 \\
\hline Ivanhoe & 40 & $\mathrm{~S}$ & weir & 22 & 29 & -- & -- & -- & 31 & .62 & $<.01$ \\
\hline Jennie Jewel & 41 & $\mathrm{~S}$ & well & 23 & 29 & -- & -- & -- & 22 & .33 & .03 \\
\hline Jessamine & 42 & $\mathrm{U}$ & well & 23 & 29 & 26 & -.37 & $<.01$ & 36 & -.42 & $<.01$ \\
\hline
\end{tabular}


Table 10. Results of statistical testing for trends in lake water levels. (Continued)

[Only lakes with at least 15 years of record are included; annual mean water levels were tested. Type: S, seepage lake; D, lake is part of surface-drainage feature. Control: pump, lake stage can be controlled by pumping; weir, weir control; well, drainage well control; cvt, culvert control, None, no manmade control of water level; <, less than; --, insufficient data for analysis. The Kendall $\mathrm{T}$ is a test statistic based on the relation of annual mean lake level with time. A positive $T$ indicates an increase in lake level with time; a negative $T$ indicates a decrease in lake level with time. The $p$-value is the probability that a pattern of increasing or decreasing water level could result from a trendless set of data. A p-value of 0.05 or less is taken as evidence of a significant trend in water level and is in bold type]

\begin{tabular}{|c|c|c|c|c|c|c|c|c|c|c|c|}
\hline \multirow{2}{*}{ Lake } & \multirow{2}{*}{$\begin{array}{l}\text { Map } \\
\text { No. }\end{array}$} & \multirow{2}{*}{ Type } & \multirow{2}{*}{$\begin{array}{l}\text { Con- } \\
\text { trol }\end{array}$} & \multirow{2}{*}{$\begin{array}{c}\text { Township } \\
\text { (South) }\end{array}$} & \multirow{2}{*}{$\begin{array}{l}\text { Range } \\
\text { (East) }\end{array}$} & \multicolumn{3}{|c|}{1970 - 1997} & \multicolumn{3}{|c|}{ Period of record } \\
\hline & & & & & & Years & Kendall T & Probability & Years & Kendall T & Probability \\
\hline Johns & 43 & $\mathrm{~S}$ & weir & 22 & 27 & 28 & .21 & 0.10 & 40 & -0.15 & 0.18 \\
\hline Killarney & 44 & $\mathrm{D}$ & well & 22 & 29 & 27 & .34 & .01 & 36 & .45 & $<.01$ \\
\hline Lawne & 45 & $\mathrm{D}$ & weir & 22 & 29 & 26 & .57 & $<.01$ & 36 & .18 & .12 \\
\hline Little Fairview & 46 & $S$ & well & 22 & 29 & 25 & -.05 & .74 & 44 & -.03 & .78 \\
\hline Lockhart & 47 & $S$ & cvt & 21 & 29 & 19 & .53 & $<.01$ & 22 & .26 & .10 \\
\hline Long & 48 & S & pump & 21 & 28 & -- & -- & -- & 22 & -.36 & .02 \\
\hline Maitland & 49 & $\mathrm{D}$ & weir & 21 & 30 & 26 & -.27 & .06 & 50 & .12 & .2 \\
\hline Mann & 50 & $S$ & well & 22 & 29 & 26 & -.07 & .61 & 36 & -.15 & .2 \\
\hline Mary & 51 & $\mathrm{~s}$ & weir & & & 22 & .22 & .17 & 24 & .30 & .04 \\
\hline Mary Jane & 52 & $\mathrm{D}$ & weir & 24 & 31 & 28 & .45 & $<.01$ & 52 & -.06 & .56 \\
\hline Mccoy & 53 & $\mathrm{U}$ & $\mathrm{cvt}$ & 21 & 28 & 22 & -.01 & .94 & 23 & .06 & .69 \\
\hline Minnehaha & 54 & $\mathrm{D}$ & weir & 21 & 30 & 21 & .05 & .76 & 22 & .07 & .63 \\
\hline Mizell & 55 & $\mathrm{D}$ & weir & 22 & 30 & -- & -- & -- & 19 & .16 & .33 \\
\hline Ola & 56 & $\mathrm{D}$ & cvt & 20 & 27 & 16 & .45 & .02 & 18 & .55 & $<.01$ \\
\hline Osceola & 57 & $\mathrm{D}$ & weir & 22 & 30 & -- & -- & -- & 19 & .14 & .4 \\
\hline Page & 58 & S & well & 21 & 28 & -- & -- & -- & 17 & -.4 & .03 \\
\hline Park \& Gem & 59 & $\mathrm{D}$ & none & 21 & 29 & 25 & -.61 & $<.01$ & 24 & -.67 & $<.01$ \\
\hline Pleasant & 60 & $S$ & well & 21 & 28 & -- & -- & -- & 17 & -.6 & $<.01$ \\
\hline Pocket & 61 & $\mathrm{U}$ & none & 24 & 28 & -- & -- & -- & 17 & .53 & $<.01$ \\
\hline Prevatt & 62 & $\mathrm{U}$ & none & 20 & 28 & 19 & .23 & .17 & 20 & .18 & .27 \\
\hline Rose & 63 & $\mathrm{U}$ & none & 22 & 28 & 26 & .26 & .06 & 36 & .03 & .76 \\
\hline Sand Lake (Big) & 64 & $S$ & $\mathrm{cvt}$ & 24 & 28 & 26 & .12 & .39 & 35 & -.34 & $<.01$ \\
\hline Sand Lake (Little) & 65 & $S$ & none & 23 & 28 & 17 & .53 & $<.01$ & 20 & .13 & .44 \\
\hline Sarah & 66 & $S$ & weir & 22 & 29 & 20 & .19 & .24 & 21 & .24 & .13 \\
\hline Shadow & 67 & $S$ & $\mathrm{cvt}$ & 21 & 29 & -- & -- & -- & 16 & .17 & .37 \\
\hline Sherwood & 68 & S & well & 22 & 28 & 26 & .21 & .13 & 34 & -.13 & .29 \\
\hline Silver & 69 & $S$ & weir & 22 & 29 & 22 & .04 & .80 & 28 & .17 & .21 \\
\hline Spring & 70 & $S$ & well & 23 & 28 & 22 & .24 & .14 & 25 & -.13 & .37 \\
\hline $\begin{array}{l}\text { Spring, No. Orange } \\
\text { Blossom Trail }\end{array}$ & 71 & $S$ & none & 22 & 29 & 18 & .03 & .85 & 39 & -.23 & .04 \\
\hline Stanley & 72 & S & well & 22 & 28 & -- & -- & -- & 17 & -.41 & .02 \\
\hline Sue & 73 & $\mathrm{D}$ & none & 22 & 30 & 25 & -.69 & $<.01$ & 44 & -.82 & $<.01$ \\
\hline Susannah & 74 & S & weir & 22 & 30 & 19 & -.25 & .13 & 26 & -.46 & $<.01$ \\
\hline Sybelia & 75 & S & well & 21 & 29 & 20 & -.08 & .60 & 20 & -.08 & .6 \\
\hline Tibet Butler & 76 & $\mathrm{D}$ & none & 23 & 28 & 26 & .36 & $<.01$ & 35 & .12 & .3 \\
\hline Turkey & 77 & S & none & 23 & 28 & -- & -- & -- & 19 & -.64 & $<.01$ \\
\hline Tyler & 78 & $\mathrm{U}$ & weir & 23 & 29 & -- & -- & -- & 23 & .28 & .06 \\
\hline Underhill & 79 & $S$ & well & 22 & 30 & 21 & -.58 & $<.01$ & 36 & -.03 & .8 \\
\hline Virginia & 80 & $\mathrm{D}$ & weir & 22 & 30 & -- & -- & -- & 19 & .15 & .36 \\
\hline Warren & 81 & $\mathrm{D}$ & none & 23 & 30 & 25 & -.31 & .03 & 34 & -.48 & $<.01$ \\
\hline Waunatta & 82 & $\mathrm{U}$ & weir & 22 & 30 & 16 & .03 & .86 & 20 & .11 & .52 \\
\hline Wekiva (Orlando) & 83 & $\mathrm{D}$ & weir & 22 & 29 & 27 & -.24 & .08 & 29 & -.38 & $<.01$ \\
\hline
\end{tabular}



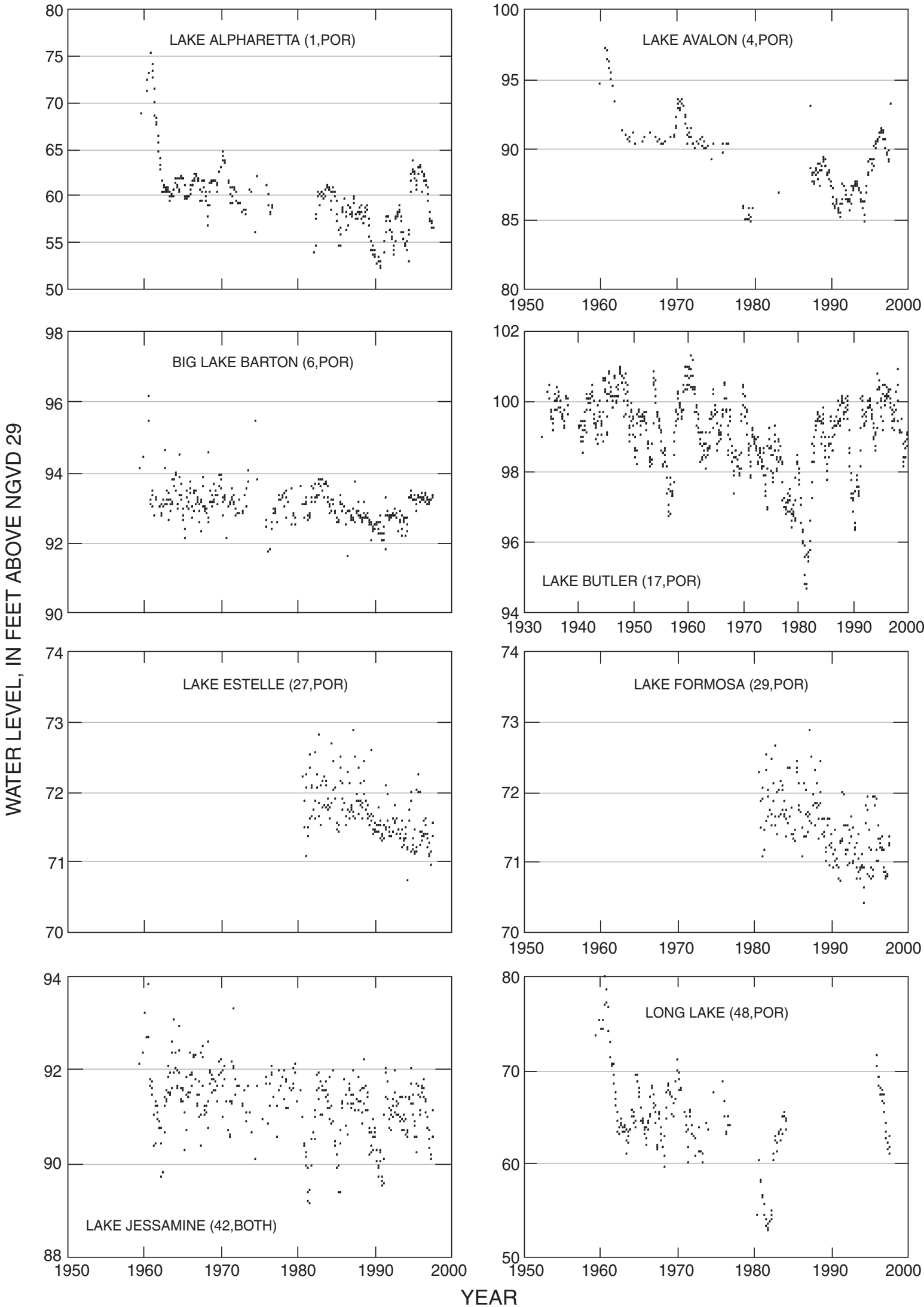

Figure 20. Lakes with a significant downward trend in water level. (Data are from USGS and Orange County Stormwater Management Division. Number in parentheses refers to location in figure 8 and appendix B. Por, trend is for entire period of record; >1970, trend is for 1970-97 only; both, trend is for period of record and also for 1970-97.) 

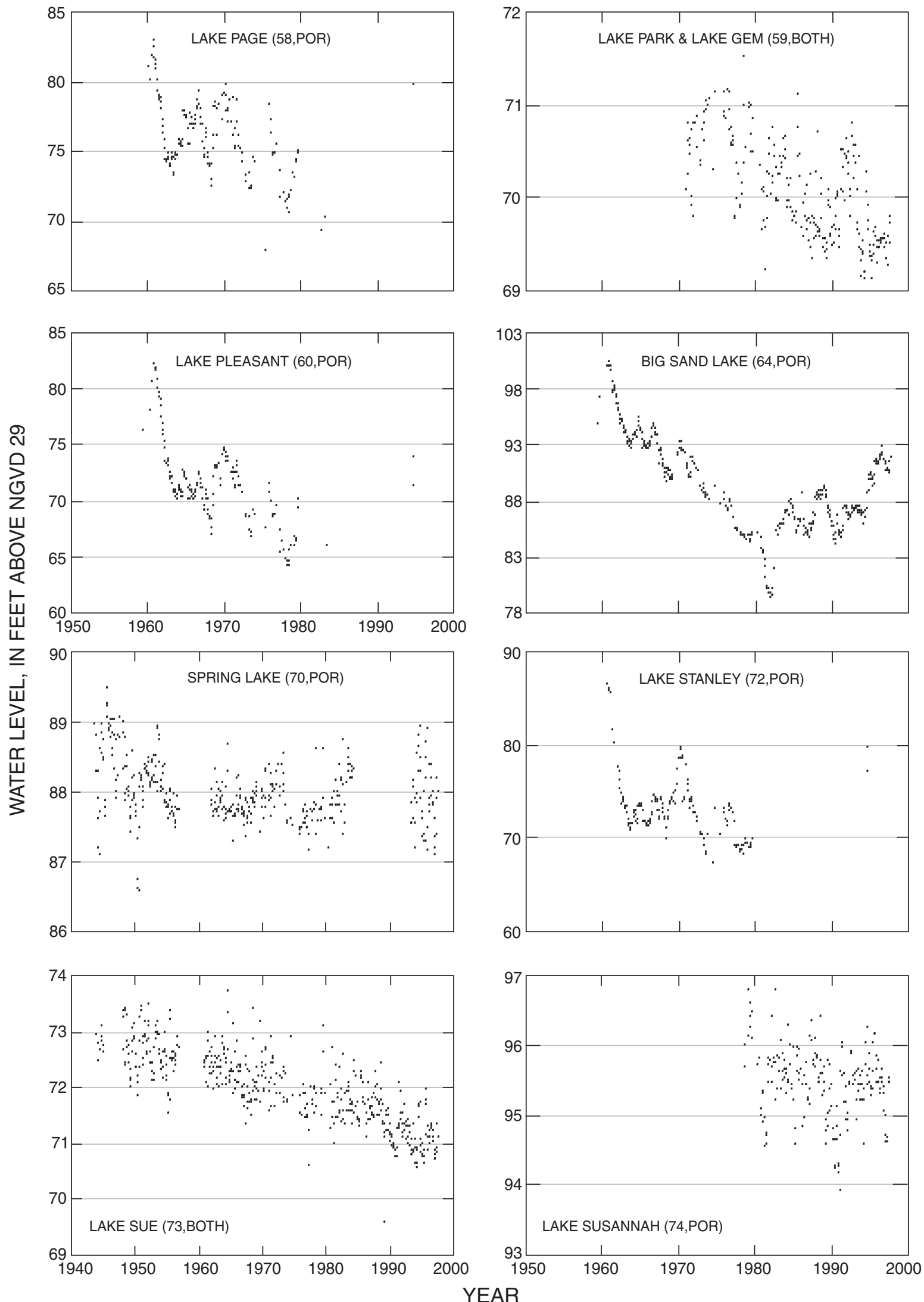

Figure 20. Lakes with a significant downward trend in water level. (Data are from USGS and Orange County Stormwater Management Division. Number in parentheses refers to location in figure 8 and appendix B. Por, trend is for entire period of record; >1970, trend is for 1970-97 only; both, trend is for period of record and also for 1970-97.) (Continued) 

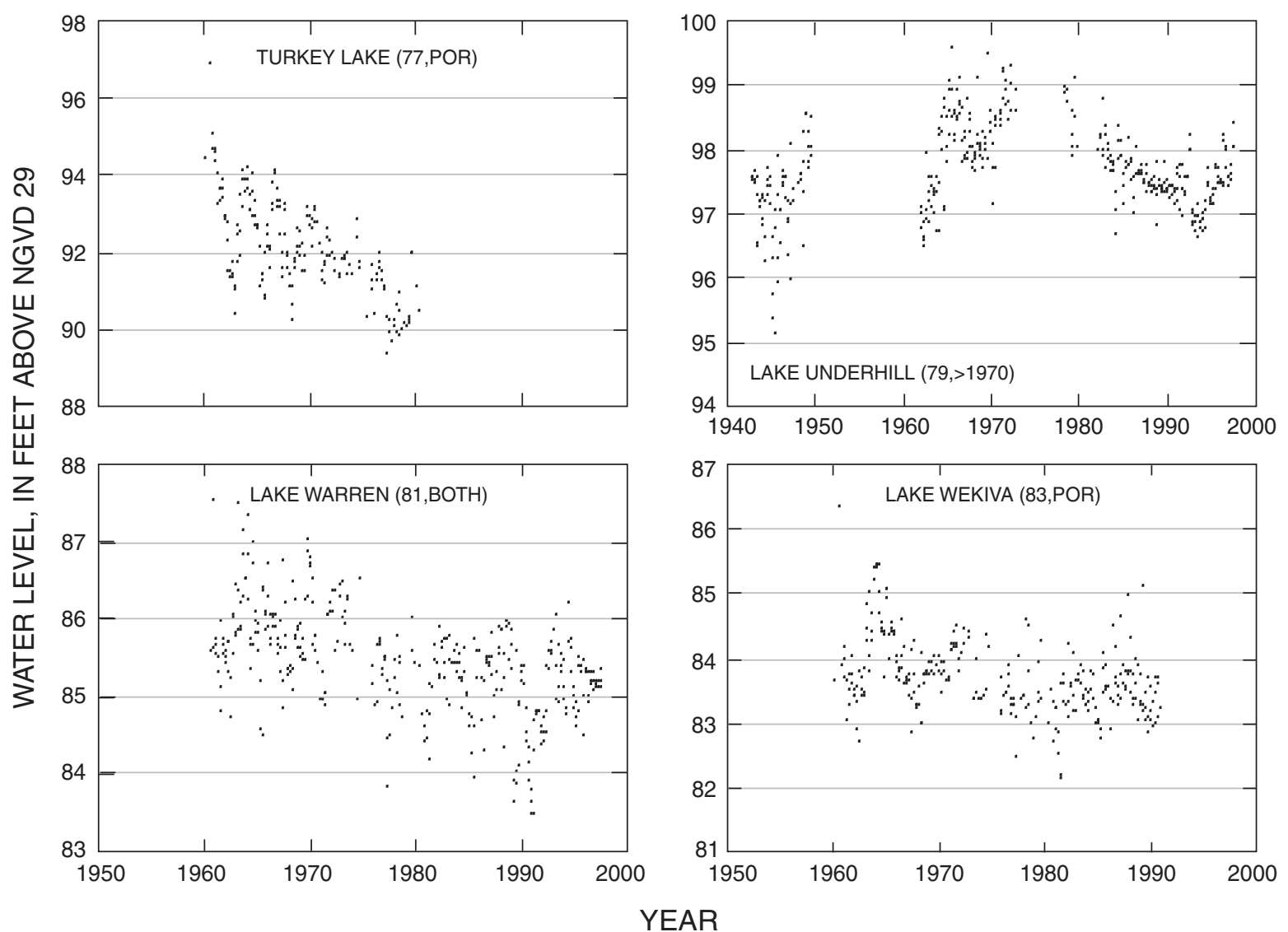

Figure 20. Lakes with a significant downward trend in water level. (Data are from USGS and Orange County Stormwater Management Division. Number in parentheses refers to location in figure 8 and appendix B. Por, trend is for entire period of record; >1970, trend is for 1970-97 only; both, trend is for period of record and also for 1970-97.) (Continued)

Lake Avalon, Lake Jessamine, Long Lake, Lake Page, Lake Pleasant, Big Sand Lake, Lake Stanley, Turkey Lake, and Lake Warren (fig. 20). All of these lakes had highwater levels during 1960-61 that exceeded water levels throughout the period of record.

The high-water levels of 1959-60 likely will never be repeated in many lakes. Since the early 1900 s, drainage wells were constructed to augment surface drainage in Orange County, when incompatibility between expanding urban land use and variable lake stages was noted (Kimrey, 1978). Flooding in 1959-60 resulted in the construction of about 35 additional drainage wells in Orange County (Lichtler and others, 1968). Most of the drainage wells are operational and are an effective flood-control measure. Drainage wells on the perimeter of many lakes probably limit the highest lake levels to the approximate elevation of the well intake. Other drainage wells intercept street runoff that otherwise would reach lakes, thereby reducing the effective drainage area (and maximum water levels) of the lakes.
For many or even most lakes, there has not been a uniform pattern of declining or increasing water level over the period of record. Instead, periods of decreasing water levels and periods of increasing water levels have occurred. Lake Butler (fig. 20) and Hickory Nut Lake (fig. 21) are two examples of lakes that had a pattern of declining water levels from 1959-60 to the early 1980s, probably indicating a change from the high-water levels resulting from heavy rainfall during 1959-60 to low water levels that occurred in the early 1980s as a result of relatively low rainfall. Following this period of decline, there was an upward water-level trend in many lakes. This pattern of lake-level fluctuations is similar to the pattern of rainfall, especially the 5-year moving average of rainfall (fig. 15).

From 1970-97, trends were indicated in 24 of the 57 lakes (42 percent) tested (table 10). Nineteen lakes had increasing water levels and five lakes had decreasing water levels. The number of lakes with trends in water levels during 1970-97 were tabulated according to lake type and to presence or absence of a manmade water-level control. 

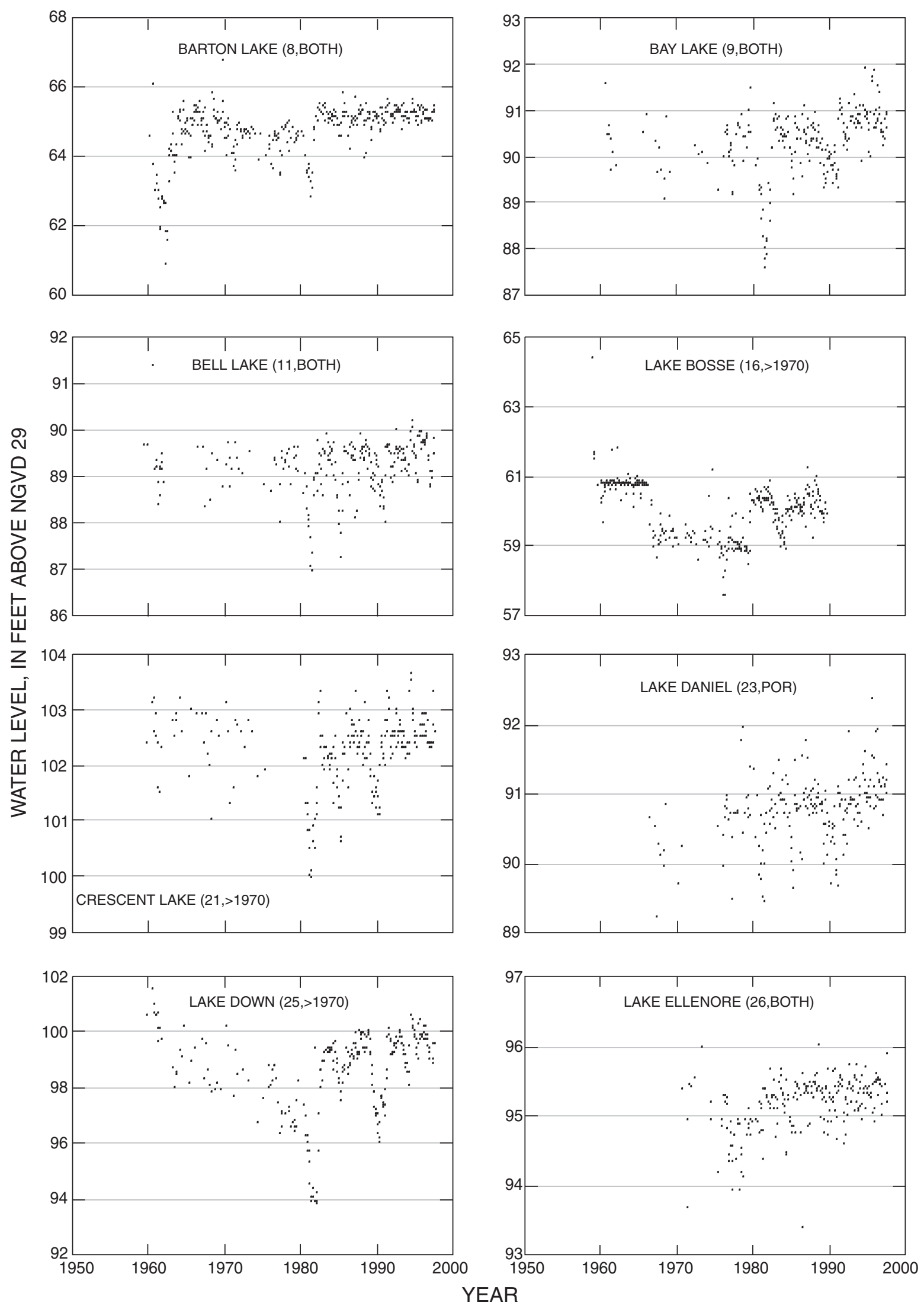

Figure 21. Lakes with a significant upward trend in water level. (Data are from USGS and Orange County Stormwater Management Division. Number in parentheses refers to location in figure 8 and appendix B. Por, trend is for entire period of record; >1970, trend is for 1970-97 only; both, trend is for period of record and also for 1970-97.) 

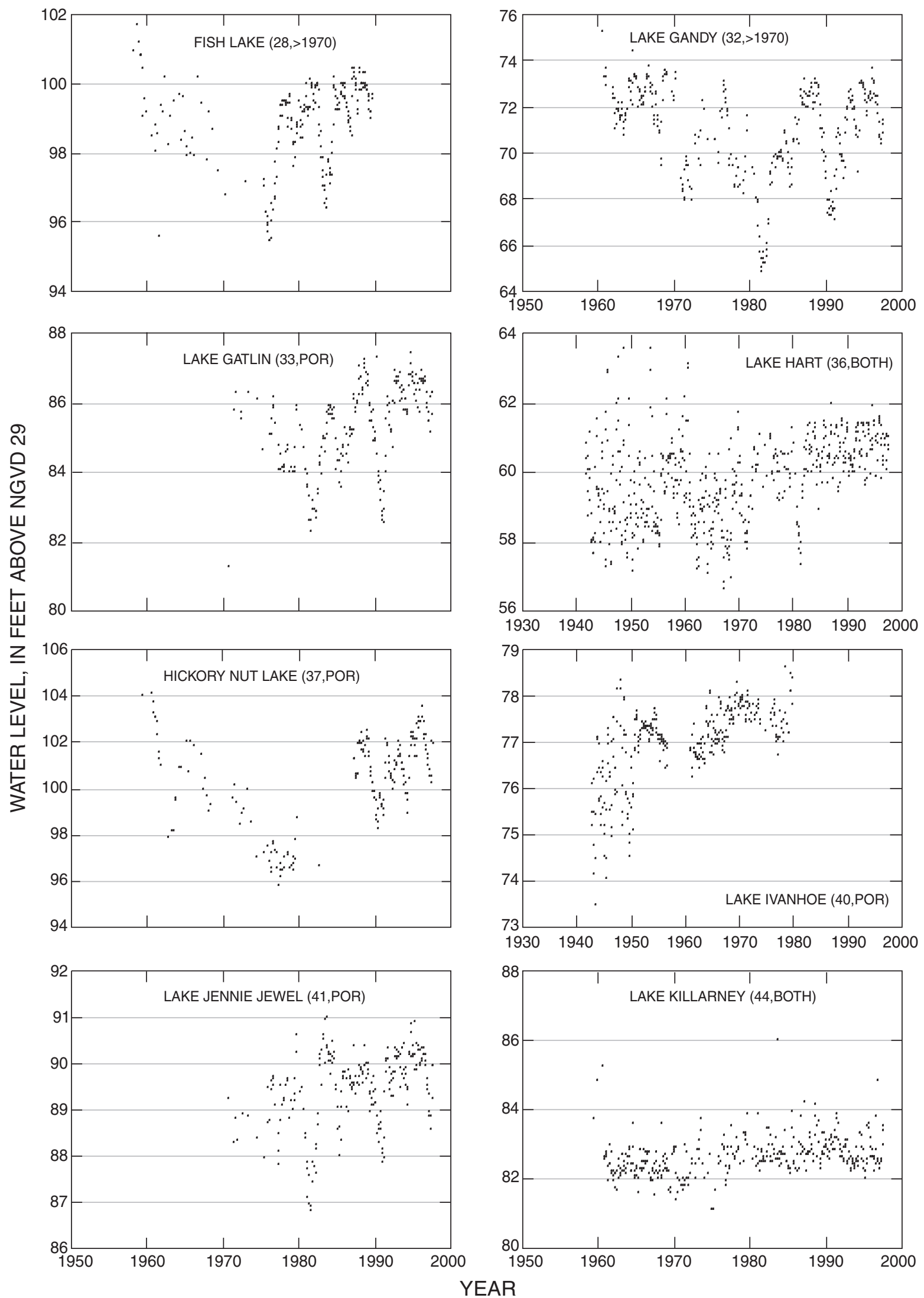

Figure 21. Lakes with a significant upward trend in water level. (Data are from USGS and Orange County Stormwater Management Division. Number in parentheses refers to location in figure 8 and appendix B. Por, trend is for entire period of record; >1970, trend is for 1970-97 only; both, trend is for period of record and also for 1970-97.) (Continued) 

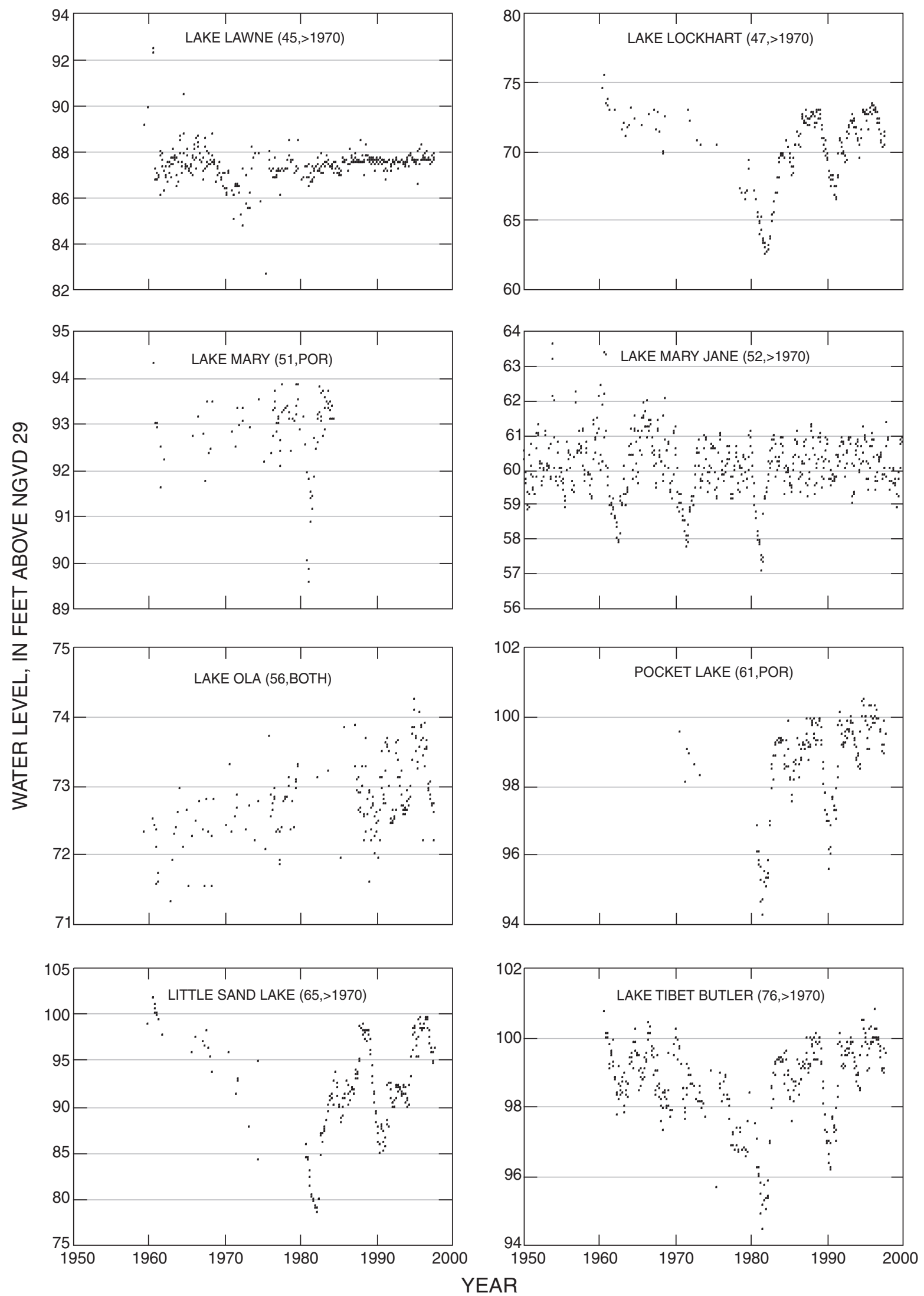

Figure 21. Lakes with a significant upward trend in water level. (Data are from USGS and Orange County Stormwater Management Division. Number in parentheses refers to location in figure 8 and appendix B. Por, trend is for entire period of record; >1970, trend is for 1970-97 only; both, trend is for period of record and also for 1970-97.) (Continued) 
The lake types considered were drainage lakes and seepage lakes. Drainage lakes lose water primarily through a surface-water outlet; seepage lakes have no surface-water outflow, losing water primarily to the ground-water system or through evaporation. Some lakes were not classified because surface-drainage features are not well defined or are likely to affect lake drainage only at relatively high-water levels.

Several types of water-level control are used. Some lakes have weirs or culverts, which direct water from the lake into streams, canals, or other lakes when the lake level reaches the elevation of the weir top or culvert floor.

Drainage wells, present on some lakes, function similar to weirs or culverts, by removing water from the lakes when lake levels reach the elevation of the well intake. Pumping stations are used intermittently at a few lakes to mitigate flooding during wet periods.

The number of lakes in each group with apparent downward trends in water levels during 1970-97 are summarized in the following table:

\begin{tabular}{lcc}
\hline \multirow{2}{*}{ Lake type } & \multicolumn{2}{c}{$\begin{array}{c}\text { Manmade water- } \\
\text { level control }\end{array}$} \\
\cline { 2 - 3 } & Yes & No \\
\hline Drainage & 0 & 3 \\
Seepage & 1 & 1 \\
Unknown & 0 & 0 \\
Total & 1 & 4 \\
\hline
\end{tabular}

Lakes with no manmade water-level controls account for four of the five lakes with downward trends in water levels. Of these four lakes, three are drainage lakes. However, no definite conclusions regarding relations between lake type and presence of water-level controls can be made, because of the small number of lakes with downward trends.

A similar comparison for lakes with apparent upward trends in water level during 1970-97 is as follows:

\begin{tabular}{lcc}
\hline \multirow{2}{*}{ Lake type } & \multicolumn{2}{c}{$\begin{array}{c}\text { Manmade water- } \\
\text { level control }\end{array}$} \\
\cline { 2 - 3 } & Yes & No \\
\hline Drainage & 7 & 2 \\
Seepage & 4 & 3 \\
Unknown & 2 & 1 \\
Total & 13 & 6 \\
\hline
\end{tabular}

Lakes with manmade water-level controls account for 13 of the 19 lakes with upward trends in water levels. However, lakes with manmade water-level controls also are the most numerous among the lakes that were tested for trends, and accounted for 37 of the 57 lakes ( 65 percent) that were tested. Therefore, this comparison probably does not indicate that the presence of manmade water-level controls is related to upward trends in water level.

The locations of lakes with sufficient water-level record for statistical trend testing for 1970-97 were plotted to determine if there were areal patterns in lakes with trends (fig. 22). The lakes are identified by number on figure 22; the map numbers are listed in appendix B. Lakes with no apparent water-level trend are widely scattered throughout Orange County. A group of six lakes with increasing water level is located in southwest Orange County. Many of these lakes are connected and are part of the Lake Butler chain: Lake Crescent (21), Lake Down (25), Lake Butler (17), and Lake Tibet-Butler (76). Increasing water levels in these lakes may be related to urban development replacing orange groves that previously occupied most of the area. Some citrus groves may have used lake water for irrigation, contributing to the water loss from lakes. However, other lakes in areas where there has been less development also have shown an increase in water level. These lakes include Barton Lake (8), Lake Hart (36), and Lake Mary Jane (52) in southeast Orange County. Several lakes in the north-central area also have shown upward water-level trends during 1970-97. These include Bay Lake (9), Bell Lake (11), Lake Bosse (16), Lake Gandy (32), Lake Killarney (44), Lawne Lake (45), and Lake Lockhart (47). The most apparent change in Lawne Lake (fig. 21), however, is a series of relatively low lake levels in the early 1970s, compared to water levels before and after this period. Lake Ola (56), in northwest Orange County, has shown a relatively consistent upward water-level trend.

Lakes with significant decreasing trends in water levels during 1970-97 are scattered throughout Orange County. For example, Lake Sue (73) had a consistent downward water-level trend from an average of about $72.5 \mathrm{ft}$ in 1950 to about $71 \mathrm{ft}$ in the late 1990s (fig. 20). Possible causes could include increased outflow from Lake Sue through the stream channel connecting Lake Sue to Lake Virginia, or increased leakage from the lake to the Upper Floridan aquifer.

\section{Streamflow Duration and Recurrence Intervals}

The computation and interpretation of streamflow duration statistics is discussed in Searcy (1959), who pointed out that, in a strict sense, flow-duration statistics are applicable only for the period of streamflow data used to compute them. Because temporal trends were identified in both high and low streamflow in many areas in Orange County, the duration statistics presented in this report 


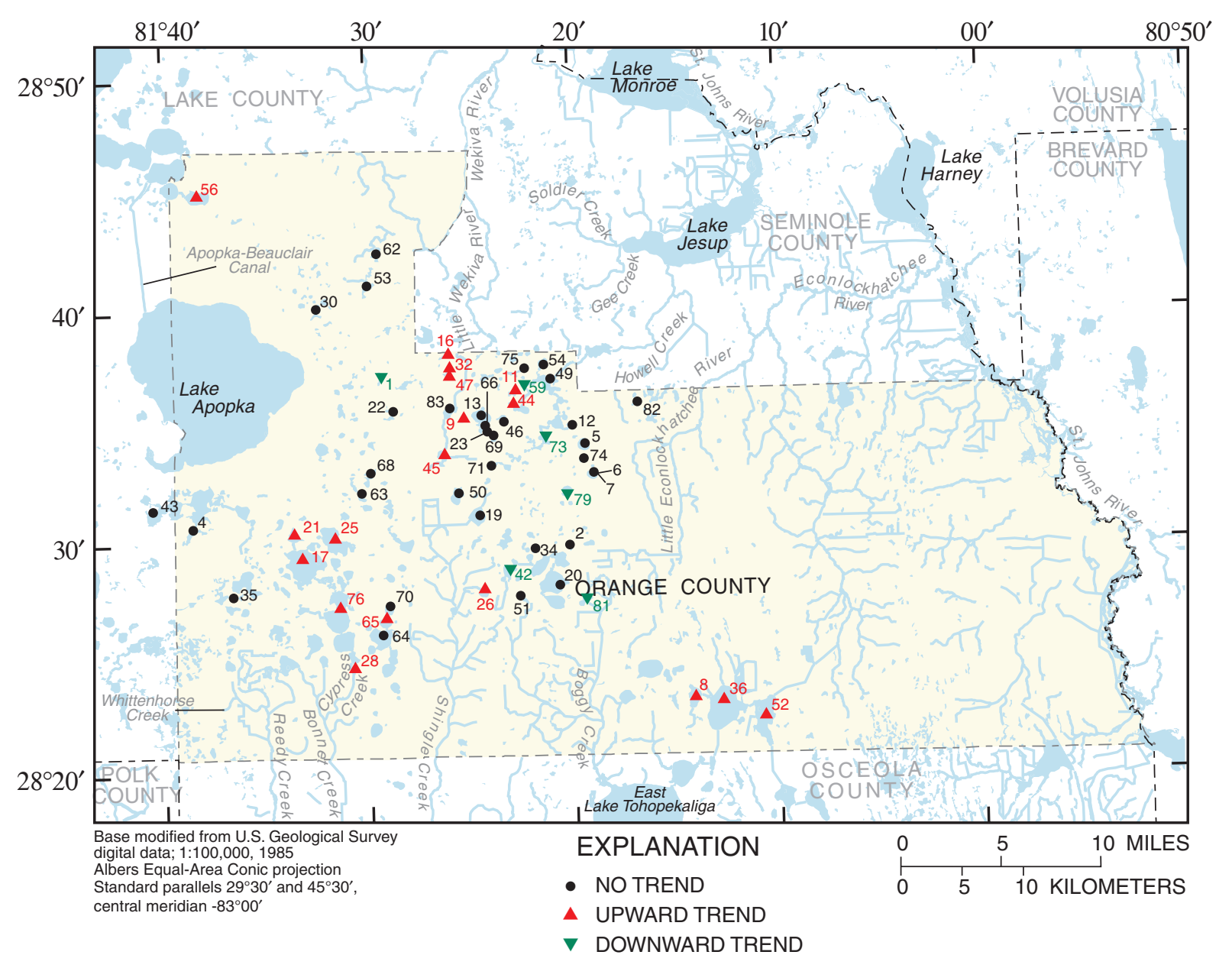

Figure 22. Lakes with trends in mean-annual water level for 1970-97. (Only lakes with at least 15 years of record are included. Number refers to appendix B.)

should not be interpreted rigorously as probability statistics, but rather as descriptive indicators of streamflow characteristics. The statistics may be useful for water-supply studies, waste-load allocation studies, and other types of studies where streamflow characteristics are necessary. The approximate nature of the duration statistics (table 11) is especially true for the smaller streams in rapidly urbanizing areas, such as the Little Econlockhatchee River, the Econlockhatchee River, Boggy Creek, Shingle Creek, Cypress Creek, Whittenhorse Creek, and Reedy Creek.

Streamflow duration statistics were computed from daily mean streamflow (table 11). For streams with no apparent temporal trends in streamflow, daily streamflow for the entire period of record was used in the duration analysis. However, for some streams, data from early periods were not used because of temporal trends in streamflow that resulted in historical data being nonrepresentative of current conditions. These streams, and the periods of record used in calculation of flow duration, are:

\begin{tabular}{clc}
\hline Site ID & \multicolumn{1}{c}{ Stream } & Period of record \\
\hline 02233200 & Little Econlockhatchee River & $1980-2000$ \\
02233500 & Econlockhatchee River & $1980-2000$ \\
\hline 02235000 & Wekiva River & $1960-2000$ \\
02262900 & Boggy Creek & $1985-2000$ \\
\hline 02263800 & Shingle Creek & $1959-1970$ \\
02266300 & Reedy Creek & $1991-2000$ \\
\hline
\end{tabular}

There were no significant temporal trends in annual mean streamflow during any of the periods listed above. For Shingle Creek, data from 1971-90 were excluded from flow-duration calculations because of the discharge of substantial amounts of treated wastewater (as much as $20 \mathrm{ft}^{3} / \mathrm{s}$ ) into the creek.

The flow-durations computed by Lichtler and others (1968) are given in table 11 for comparison with those computed in this study. While not greatly different in most cases, the streamflow durations calculated in this study for 
Table 11. Flow-duration characteristics for selected streams in Orange County and adjacent counties. [Streamflows in cubic foot per second]

\begin{tabular}{|c|c|c|c|c|c|c|c|c|c|}
\hline \multirow{2}{*}{$\begin{array}{l}\text { USGS } \\
\text { identifier }\end{array}$} & \multirow[t]{2}{*}{ Name } & \multirow{2}{*}{$\begin{array}{l}\text { Period } \\
\text { of record }\end{array}$} & \multicolumn{7}{|c|}{$\begin{array}{l}\text { Streamflows for selected percentiles } \\
\text { (Percent of time streamflow exceeds indicated discharge) }\end{array}$} \\
\hline & & & 99 & 90 & 75 & 50 & 25 & 10 & 1 \\
\hline \multirow[t]{2}{*}{02232400} & St Johns River near Cocoa & $1954-2000$ & 18 & 94 & 226 & 593 & 1,350 & 2,390 & 5,410 \\
\hline & & $1954-1962^{\mathrm{a}}$ & 29 & 100 & 250 & 750 & 1,800 & 2,900 & 6,800 \\
\hline \multirow[t]{2}{*}{02232500} & St Johns River near Christmas & $1935-2000$ & 24 & 110 & 300 & 810 & 1,800 & 3,200 & 7,000 \\
\hline & & $1935-1962^{\mathrm{a}}$ & 29 & 110 & 300 & 900 & 1,800 & 3,500 & 8,000 \\
\hline \multirow[t]{2}{*}{02233200} & Little Econlockhatchee River near & $1960-2000$ & .9 & 3.7 & 7.4 & 16 & 33 & 69 & 270 \\
\hline & Union Park & $1960-1962^{\mathrm{a}}$ & $<.1$ & .5 & 1.8 & 5 & 15 & 42 & 210 \\
\hline \multirow[t]{2}{*}{02233500} & Econlockhatchee River near Chuluota & $1936-2000$ & 14 & 32 & 55 & 110 & 300 & 700 & 2,300 \\
\hline & & $1936-1962^{\mathrm{a}}$ & 11 & 22 & 40 & 90 & 290 & 680 & 2,700 \\
\hline \multirow[t]{2}{*}{02235000} & Wekiva River near Sanford & $1936-2000$ & 160 & 200 & 230 & 260 & 330 & 440 & 910 \\
\hline & & $1936-1962^{a}$ & 170 & 190 & 210 & 240 & 300 & 400 & 850 \\
\hline 02237700 & Apopka-Beauclair Canal & 1959-1999 & .02 & 7.1 & 18 & 29 & 38 & 268 & 529 \\
\hline \multirow[t]{2}{*}{02262900} & Boggy Creek near Taft & $1960-2000$ & .4 & 4.9 & 11 & 25 & 62 & 140 & 490 \\
\hline & & $1960-1962^{\mathrm{a}}$ & $<.1$ & .5 & 5 & 18 & 65 & 120 & 460 \\
\hline \multirow[t]{2}{*}{02263800} & Shingle Creek near Kissimmee & $1959-2000$ & .06 & 7.8 & 19 & 41 & 92 & 194 & 540 \\
\hline & & $1959-1962^{\mathrm{a}}$ & $<.1$ & $<.1$ & .9 & 12 & 55 & 150 & 520 \\
\hline \multirow[t]{2}{*}{02264000} & Cypress Creek near Vineland & $1946-2000$ & 0 & .04 & .1 & .9 & 4.7 & 19 & 81 \\
\hline & & $1946-1962^{\mathrm{a}}$ & $<.1$ & $<.1$ & .4 & 2.1 & 11 & 32 & 95 \\
\hline 02266200 & Whittenhorse Creek near Vineland & $1967-2000$ & 0 & .03 & .06 & .82 & 6.2 & 15 & 44 \\
\hline 02266300 & Reedy Creek near Vineland & $1967-2000$ & .09 & 6.7 & 12 & 23 & 48 & 94 & 290 \\
\hline
\end{tabular}

${ }^{\mathrm{a}}$ From plots of Lichtler and others (1968).

streams other than the St. Johns River tend to be greater than those given by Lichtler and others (1968), especially for streamflows that were exceeded 25 percent of the time or more. Differences in streamflow duration calculated by Lichtler and others (1968) and the present study may be related to changes in basin land use, as discussed previously, or by differences in the period of record available for the computations. Lichtler and others (1968) had 10 years of daily streamflow data for the St. John River near Cocoa, 4 or 5 years of record for Boggy Creek, Shingle Creek, and Little Econlockhatchee River, and only periodic measurements of discharge for Reedy Creek.

Low-flow frequency statistics typically are computed for the 7-day average annual minimum flow, although any number ( $\mathrm{n}$ ) of consecutive days could be considered. The determination of n-day low-flow recurrence intervals is a two-step process. First, the lowest (or highest) streamflow average for an n-day period is determined for each year. Then, recurrence intervals for these n-day low or high flows are computed using log-Pearson analysis (Riggs, 1968).
A similar procedure is used for high-flow frequency statistics. Guidelines and procedures of the Interagency Advisory Committee on Water Data (1982) were used when completing the log-Pearson analysis.

Ideally, the streamflow data series should contain no temporal trends; otherwise, the recurrence intervals calculated from the series will not be representative of current conditions. Two approaches may be used to more accurately estimate flow recurrence in streams that have a temporal trend in streamflow. One approach is to limit the data series to a trendless period that represents present conditions, if such a period exists. Another approach is to "detrend" the data by determining the relation between the annual streamflow characteristic and time, and by using this relation to "correct" data in the annual data series for all previous years to estimate the flow that would have occurred each year in the past if the temporal trend had been absent. Although this detrending procedure probably provides a more accurate estimate of recurrence intervals than the use of unadjusted data would provide, the accuracy of recurrence intervals computed from detrended data 
is difficult to assess. The function used to detrend the data is an approximation that may introduce error into the data series used in the recurrence-interval calculation. Also, any future change in a streamflow trend will make recurrence intervals calculated using data prior to the trend change inaccurate. The fact that a trend exists in a streamflow characteristic is an indication that the stream may be sensitive to factors such as land-use or water-use changes and that recurrence intervals are likely to change in response to many types of basin development.

The 7-day low-flow data series for some streams were adjusted to remove effects of temporal trends when the plotted data indicated that a relatively uniform trend in the data was present (fig. 16). Adjustments were made using the median of all ratios $\left(Q_{i}-Q_{j}\right) /\left(Y_{i}-Y_{j}\right)$, where $Q_{i}$ and $Q_{j}$ are the magnitudes of the 7-day low flows and $\mathrm{Yi}$ and $\mathrm{Yj}$ are the corresponding years. In this notation, $\mathrm{i}$ ranges from $B$ to $E-1$, and $j$ ranges from $B+1$ to $E$, where $B$ is the first year of record and $\mathrm{E}$ is the last year of record. The USGS computer program SWSTAT (Alan Lumb, Wilbert O. Thomas, Jr., and Kathleen Flynn, U.S. Geological Survey, written commun., 1994) was used to compute the median ratio, commonly referred to as the slope estimator. Detrended values of 7-day low flow are given by:

$$
\mathrm{D}_{\mathrm{i}}=\mathrm{S}(\mathrm{E}-\mathrm{i})+\mathrm{Q}_{\mathrm{i}},
$$

where

$$
\begin{aligned}
& \mathrm{D}_{\mathrm{i}}=\text { the detrended flow for year } \mathrm{i} \\
& \mathrm{S}=\text { the slope estimator for the period of record being } \\
& \quad \text { detrended, in cubic feet per second per year; } \\
& \mathrm{E}=\text { the ending year for the trend, determined by } \\
& \text { examining plotted data (fig. 16); and } \\
& \mathrm{Q}_{\mathrm{i}}=\text { the 7-day low flow for year } \mathrm{i} .
\end{aligned}
$$

The slope estimator and ending year for detrending are given in the following table.

\begin{tabular}{clrc}
\hline Site ID & \multicolumn{1}{c}{ Stream } & $\begin{array}{c}\text { Slope } \\
\text { estimator }\end{array}$ & $\begin{array}{c}\text { Years } \\
\text { detrended }\end{array}$ \\
\hline 02233200 & Little Econlockhatchee River & 0.18 & $1960-1990$ \\
02233500 & Econlockhatchee River & .60 & $1936-1980$ \\
02262900 & Boggy Creek & .11 & $1960-2000$ \\
02266300 & Reedy Creek & .24 & $1967-2000$ \\
\hline
\end{tabular}

For Shingle Creek, data from 1971-1990 were excluded from recurrence-interval calculations because of the discharge of treated wastewater (as much as $20 \mathrm{ft} 3 / \mathrm{s}$ ) into the creek. For the Wekiva River, the trendless period 19602000 was used for calculation of the recurrence intervals.
The 7-day low flows which occur, on average, every 2 and 10 years generally are higher than those computed by Lichtler and others (1968) (table 12). The differences are greatest for 7-day low flows in the Econlockhatchee River, where the 2-year and 10-year low flow values computed in the present study are more than 70 percent greater than those computed by Lichtler and others (1968). Differences between the 365-day low flows in the Econlockhatchee River are much smaller (less than 20 percent). Recurrence intervals computed for the St. Johns River and Wekiva River in the present study are within about 30 percent of the values given by Lichtler and others (1968), and generally are within about 10 percent.

These differences between low-flow frequency statistics computed by Lichtler and others (1968) and in the present study probably reflect differences in period of record as well as changes in land use. The period of record used by Lichtler and others (1968) was 27 to 29 years, whereas the present study used 41 years of record beginning in 1960 for the Wekiva River and more than 60 years of record for the Econlockhatchee River and the St. Johns River. The relatively large differences in recurrence intervals for the Econlockhatchee River may reflect land-use changes that relate to the trend for increasing 7-day low flows during 1936 to the mid-1980s.

\section{Water Quality}

Water-quality data for 15 stream sites and 140 lakes are summarized in the following sections. Areal patterns of water quality and temporal trends in stream quality are discussed. Types of water-quality data include major ions and nutrients, trace elements, pesticides, and household and industrial waste compounds.

Rainfall, streamflow, and lake levels during 20002001 were relatively low. Therefore the sampling that was performed during this study may not be representative of wetter conditions. The effects of varying streamflow are described for some constituents with sufficient historical record.

\section{Major lons and Nutrients in Streams}

A large range of water-quality conditions exists in streams of Orange County (table 13). For example, specific conductance in samples from streams ranged from 84 microsiemens per centimeter $(\mu \mathrm{S} / \mathrm{cm})$ to $617 \mu \mathrm{S} / \mathrm{cm}$, with a median value of $269 \mu \mathrm{S} / \mathrm{cm}$. Other water-quality indicators and constituents also had wide ranges of values and concentrations in samples. Values of $\mathrm{pH}$ ranged from 3.2 
Table 12. Low and high-flow frequency statistics for selected streams in and near Orange County.

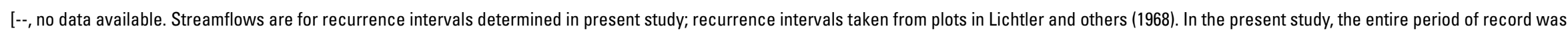
used except for Shingle Creek, where data from 1971-90 were excluded because of discharge of treated wastewater into the creek. The 7-day low-flow recurrence intervals were computed using de-trended annual flows as follows: Little Econlockhatchee River, $0.18 \mathrm{ft}^{3} / \mathrm{s}-\mathrm{yr}$; Econlockhatchee River, $0.60 \mathrm{ft} / 3 / \mathrm{s}-\mathrm{yr}$; Boggy Creek, $0.11 \mathrm{ft} / 3 / \mathrm{s}-\mathrm{yr}$; Reedy Creek, $0.24 \mathrm{ft} 3 / \mathrm{s}-\mathrm{yr}$. The 1 -day high-flow statistics were computed using Bulletin 17B guidelines (Interagency Advisory Committee on Water Data, 1982) and include upper and lower 95-percent confidence limits for the estimated 1-day high streamflow, in parentheses]

\begin{tabular}{|c|c|c|c|c|c|c|c|c|c|c|c|}
\hline \multirow{2}{*}{$\begin{array}{l}\text { USGS } \\
\text { identifier }\end{array}$} & \multirow{2}{*}{ Name } & \multirow{2}{*}{$\begin{array}{l}\text { Period } \\
\text { of } \\
\text { record }\end{array}$} & \multicolumn{3}{|c|}{ 1-day high flow } & \multicolumn{3}{|c|}{ 7-day low flow } & \multicolumn{3}{|c|}{ 365-day low flow } \\
\hline & & & 2-year & 10-year & 50-year & 2-year & 10-year & 50-year & 2-year & 10-year & 50-year \\
\hline 02232400 & St. Johns River near Cocoa & $1954-2000$ & $\begin{array}{c}3,000 \\
(2,500-3,500)\end{array}$ & $\begin{array}{c}6,500 \\
(5,400-8,200)\end{array}$ & $\begin{array}{c}10,000 \\
(7,900-14,000)\end{array}$ & 97 & 22 & 8.2 & 950 & 340 & 140 \\
\hline \multirow[t]{2}{*}{02232500} & St. Johns River near Christmas & $1935-2000$ & $\begin{array}{c}4,000 \\
(3,600-4,500)\end{array}$ & $\begin{array}{c}7,800 \\
(6,900-9,300)\end{array}$ & $\begin{array}{c}12,000 \\
(9,900-15,000)\end{array}$ & 140 & 20 & 3.8 & 1,300 & 520 & 240 \\
\hline & & $1935-1962^{\mathrm{a}}$ & -- & -- & -- & 130 & 22 & -- & 1,200 & 420 & -- \\
\hline 02233200 & $\begin{array}{l}\text { Little Econlockhatchee River near } \\
\text { Union Park }\end{array}$ & $1960-2000$ & $\begin{array}{c}340 \\
(280-420)\end{array}$ & $\begin{array}{c}840 \\
(660-1,100)\end{array}$ & $\begin{array}{c}1,300 \\
(990-1,900)\end{array}$ & 6.4 & 3.6 & 2.3 & 28 & 13 & 7.6 \\
\hline \multirow[t]{2}{*}{02233500} & Econlockhatchee River near Chuluota & $1936-2000$ & $\begin{array}{c}2,400 \\
(2,100-2,800)\end{array}$ & $\begin{array}{c}5,800 \\
(4,900-7,400)\end{array}$ & $\begin{array}{c}9,500 \\
(7,500-13,000)\end{array}$ & 38 & 29 & 26 & 250 & 130 & 84 \\
\hline & & $1936-1962^{\mathrm{a}}$ & -- & -- & -- & 22 & 12 & -- & 220 & 110 & -- \\
\hline \multirow[t]{2}{*}{02235000} & Wekiva River near Sanford & $1936-2000$ & $\begin{array}{c}800 \\
(740-880)\end{array}$ & $\begin{array}{c}1,400 \\
(1,200-1,500)\end{array}$ & $\begin{array}{c}1,800 \\
(1,600-2,200)\end{array}$ & 200 & 170 & 161 & 280 & 230 & 210 \\
\hline & & $1936-1962^{\mathrm{a}}$ & -- & -- & -- & 180 & 130 & -- & 260 & 210 & -- \\
\hline 02237700 & Apopka-Beauclair Canal & $1959-1999$ & $\begin{array}{c}310 \\
(240-410)\end{array}$ & $\begin{array}{c}910 \\
(670-1,300)\end{array}$ & $\begin{array}{c}1,500 \\
(1,000-2,300)\end{array}$ & 22 & 3.3 & 0.4 & 62 & 25 & 14 \\
\hline 02262900 & Boogy Creek near Taft & $1960-2000$ & $\begin{array}{c}450 \\
(370-550)\end{array}$ & $\begin{array}{c}1,100 \\
(890-1,500)\end{array}$ & $\begin{array}{c}1,900 \\
(1,400-2,800)\end{array}$ & 5.1 & 2.0 & 0 & 49 & 23 & 14 \\
\hline 02263800 & Shingle Creek near Kissimmee & $\begin{array}{l}1959-1970 \\
1991-2000\end{array}$ & $\begin{array}{c}510 \\
(420-610)\end{array}$ & $\begin{array}{c}1,200 \\
(990-1,700)\end{array}$ & $\begin{array}{c}2,000 \\
(1,600-3,000)\end{array}$ & 0 & 0 & 0 & 75 & 33 & 17 \\
\hline 02264000 & Cypress Creek near Vineland & $1946-2000$ & $\begin{array}{c}28 \\
(21-37)\end{array}$ & $\begin{array}{c}110 \\
(80-170)\end{array}$ & $\begin{array}{c}215 \\
(150-350)\end{array}$ & 0 & 0 & 0 & 2.5 & 0.3 & .08 \\
\hline 02266200 & Whittenhorse Creek near Vineland & $1967-2000$ & $\begin{array}{c}21 \\
(16-29)\end{array}$ & $\begin{array}{c}69 \\
(48-110)\end{array}$ & $\begin{array}{c}120 \\
(80-210)\end{array}$ & 0 & 0 & 0 & 3 & .2 & 0 \\
\hline 02266300 & Reedy Creek near Vineland & $1967-2000$ & $\begin{array}{c}300 \\
(250-360)\end{array}$ & $\begin{array}{c}690 \\
(550-930)\end{array}$ & $\begin{array}{c}1,100 \\
(830-1,600)\end{array}$ & 7 & 0 & 0 & 36 & 18 & 11 \\
\hline
\end{tabular}

${ }^{\mathrm{a}}$ From Lichtler and others (1968). 
Table 13. Summary statistics of water-quality indicators and chemical constituents in samples from 15 streams, 1997-2002.

[Data source: Orange County Environmental Protection Division and U.S. Geological Survey. ${ }^{\circ}$ C, degrees Celsius; all units are in milligrams per liter unless otherwise noted; $\mu \mathrm{S} / \mathrm{cm}$, microsiemens per centimeter; $\mu \mathrm{g} / \mathrm{L}$, micrograms per liter; $<$, less than]

\begin{tabular}{|c|c|c|c|c|c|c|}
\hline Constituent & $\begin{array}{c}\text { No. } \\
\text { of } \\
\text { samples }\end{array}$ & Minimum & $\begin{array}{c}\text { 25th } \\
\text { percentile }\end{array}$ & Median & $\begin{array}{c}\text { 75th } \\
\text { percentile }\end{array}$ & Maximum \\
\hline Water temperature, ${ }^{\circ} \mathrm{C}$ & 62 & 12.8 & 21 & 24.5 & 26.4 & 29.7 \\
\hline Specific conductance, $\mu \mathrm{S} / \mathrm{cm}$ & 62 & 84 & 205 & 269 & 305 & 617 \\
\hline Dissolved oxygen & 62 & .2 & 2.9 & 4.6 & 6.2 & 9.5 \\
\hline $\mathrm{pH}$, standard units & 62 & 3.2 & 6.2 & 6.7 & 7.2 & 8.7 \\
\hline Calcium & 40 & 2 & 13 & 23 & 32 & 47 \\
\hline Magnesium & 40 & 1.6 & 2.9 & 4 & 5.4 & 25 \\
\hline Sodium & 40 & 6.2 & 11 & 15 & 23 & 57 \\
\hline Potassium & 40 & .8 & 2.2 & 3.2 & 4.1 & 15 \\
\hline Bicarbonate & 40 & $<1.0$ & 29 & 51 & 96 & 194 \\
\hline Sulfate & 40 & .8 & 9.9 & 16 & 22 & 110 \\
\hline Chloride & 40 & 11 & 20 & 27 & 39 & 120 \\
\hline Fluoride & 40 & $<.1$ & $<.1$ & .08 & .14 & .59 \\
\hline Nitrite plus nitrate as nitrogen & 62 & $<.02$ & .02 & .06 & .18 & 1.2 \\
\hline Nitrite as nitrogen & 51 & $<.01$ & $<.01$ & $<.01$ & $<.01$ & .03 \\
\hline Ammonia as nitrogen, total & 16 & .02 & .03 & .04 & .11 & 1.8 \\
\hline Ammonia as nitrogen, dissolved & 46 & $<.01$ & $<.01$ & .02 & .06 & .77 \\
\hline Ammonia plus organic nitrogen as nitrogen, total & 62 & $<.2$ & .59 & .77 & 1.5 & 7.1 \\
\hline Nitrogen, total & 62 & .3 & .74 & .97 & 1.6 & 7.1 \\
\hline Phosphorus, total & 62 & $<.02$ & .03 & .07 & .11 & .3 \\
\hline Orthophosphate as phosphorus & 46 & $<.01$ & .01 & .05 & .08 & .23 \\
\hline Organic carbon, total & 62 & .8 & 9.8 & 16 & 30 & 68 \\
\hline Chlorophyll- $a, \mu \mathrm{g} / \mathrm{L}$ & 45 & $<.1$ & $<.1$ & $<.1$ & 5.3 & 41 \\
\hline
\end{tabular}

to 8.7 (table 13). The low $\mathrm{pH}$ values that occur in some streams probably are the result of leaching of organic acids such as tannic acid in situations where water stands in contact with plant debris for extended periods of time. These low $\mathrm{pH}$ values may be accompanied by high-water color, also leached from the plant debris (German, 1986).

Nutrients and chlorophyll- $a$ also had large ranges of concentrations. Total nitrogen concentrations ranged from 0.3 to $7.1 \mathrm{mg} / \mathrm{L}$ as nitrogen in samples from streams (table 13). The U.S. Environmental Protection Agency (USEPA) has recommended that total nitrogen concentrations in central Florida streams not exceed $0.9 \mathrm{mg} / \mathrm{L}$ (U.S. Environmental Protection Agency, 2000a). This criteria was exceeded in more than one-half of the samples taken of water from streams during this study. The Florida Department of Environmental Protection (FDEP) is developing new nutrient criteria for streams that will apply to specific regions within Florida, based on water-quality data. These new criteria probably will provide a better means for assessing water quality than the more general USEPA criteria.
Comparison of concentrations of various forms of nitrogen indicates that most of the nitrogen is in the form of organic nitrogen. Total ammonia plus organic nitrogen ranged from less than 0.2 to $7.1 \mathrm{mg} / \mathrm{L}$ as nitrogen in samples from streams; however, concentrations of total ammonia were less than or equal to $0.04 \mathrm{mg} / \mathrm{L}$ as nitrogen in about 50 percent of the samples (table 13).

Few pristine streams exist in Orange County; assessing natural or background concentrations of nitrogen is difficult. Jim Creek, which flows through the Tosohatchee State Reserve, probably is the most pristine stream in Orange County, and was sampled twice during this study. The two samples from Jim Creek had ammonia plus organic nitrogen concentrations in whole-water samples (unfiltered) of 1.5 and $1.6 \mathrm{mg} / \mathrm{L}$ as nitrogen. The nitrite plus nitrate concentrations in Jim Creek were less than $0.1 \mathrm{mg} / \mathrm{L}$ in both samples. Hence, concentrations of total nitrogen (sum of nitrite, nitrate, ammonia, and organic nitrogen) may be considerably greater than the USEPA recommended criteria of $0.9 \mathrm{mg} / \mathrm{L}$, even in apparently pristine streams. 
Concentrations of total nitrogen that exceeded $2.0 \mathrm{mg} / \mathrm{L}$ as nitrogen were present in samples from the Apopka-Beauclair Canal, Bonnet Creek, Cypress Creek, Reedy Creek, and Whittenhorse Creek. Land use in these stream basins historically has been agricultural, but is changing to urban and residential; hence, determining the source of nitrogen in these samples is difficult.

Concentrations of total phosphorus ranged from less than 0.02 to $0.30 \mathrm{mg} / \mathrm{L}$ as phosphorus in samples from streams. Most, but not all, of the phosphorus present was as orthophosphate (table 13). The USEPA recommended that total phosphorus concentrations in streams not exceed $0.04 \mathrm{mg} / \mathrm{L}$ (U.S. Environmental Protection Agency, 2000a). This criterion was exceeded in more than one-half of the samples of water from streams taken during this study (table 13).

Chlorophyll- $a$ ranged from less than 0.1 to $41 \mu \mathrm{g} / \mathrm{L}$ in samples from streams (table 13). Chlorophyll- $a$ is indicative of phytoplankton (algae and cyanobacteria) in the water. Certain species of cyanobacteria, such as those of the genera Microcystis and Cylindrospermopsis, can produce toxins (mycrocystin and cylindrospermopsin, respectively) that can be released into the water (Van Dolah, 2002). Currently, no drinking water or other health related regulations are associated with these toxins (U.S. Environmental Protection Agency, 2002). However, the World Health Organization (2002) has a drinking-water guideline for mycrocystin of $1 \mu \mathrm{g} / \mathrm{L}$.

A number of streams in and around Orange County are listed as impaired in the State of Florida's 303(d) list for 1998 (Florida Department of Environmental Protection, 2002). Sites on the 303(d) list have quality of water that does not support designated uses. These streams include the Econlockhatchee River, Little Econlockhatchee River, Little Wekiva River, Reedy Creek, and Shingle Creek.

Specific conductance of water from streams draining Orange County has considerable spatial variation and ranged from 84 to $617 \mu \mathrm{S} / \mathrm{cm}$ with a median of $269 \mu \mathrm{S} / \mathrm{cm}$ (table 13). Low values of specific conductance were in samples from Jim Branch $(84 \mu \mathrm{S} / \mathrm{cm})$ in south-central Orange County and Whittenhorse Creek $(85 \mu \mathrm{S} / \mathrm{cm})$ (U.S. Geological Survey, 2004a) in southwestern Orange County. High values of specific conductance were in samples from Jim Creek $(617 \mu \mathrm{S} / \mathrm{cm})$ in eastern Orange County and the Econlockhatchee River $(529 \mu \mathrm{S} / \mathrm{cm})$ near Chuluota in south-central Seminole County.

The relatively high specific conductance in samples from Jim Creek may be related to seepage of water from the Upper Floridan aquifer into the surficial aquifer system, which provides baseflow to Jim Creek. Data from two lakes in Tosohatchee State Reserve indicate discharge of ground water from the Upper Floridan aquifer in the area. Jim Creek can go dry during drought conditions, which indicates that Jim Creek does not receive discharge directly from the Upper Floridan aquifer. However, the water quality of the surficial aquifer system, which contributes water to Jim Creek during baseflow conditions, is affected by discharge from the Upper Florida aquifer. Specific conductance in samples from four wells in the Jim Creek basin that tap the surficial aquifer system were 508, $1,140,1,180$, and $3,990 \mu \mathrm{S} / \mathrm{cm}$. The relatively high specific conductance in samples from the Econlockhatchee River is probably related to treated wastewater discharge to the river, and to seepage of water from the Upper Floridan aquifer into the stream.

In general, the relative concentrations of the ionic constituents in streams appear to be related to geology and land use. The Wekiva River contains calcium-bicarbonate water because a large percentage of its discharge is from Wekiva Springs, which issues from the Upper Floridan aquifer. Ground water in the Upper Floridan aquifer generally is calcium or calcium-magnesium bicarbonate type as a result of dissolution of the carbonate rocks of the aquifer (Adamski and Knowles, 2001). Other streams - such as Cypress Creek, Jim Branch, and Whittenhorse Creekgenerally have relatively low specific conductance and a sulfate or chloride type water because they do not receive substantial quantities of wastewater or seepage from the Upper Floridan aquifer.

Other streams, such as Boggy Creek, the Econlockhatchee River, and Shingle Creek, have bicarbonate or mixed anion type water, which could result from the effects of land use as much as from geology. Water used for lawn irrigation generally is from the Upper Floridan aquifer. Calcium and bicarbonate concentrations in stream water could be affected by runoff from lawn irrigation. In addition, the Little Econlockhatchee River receives reclaimed water from a wastewater treatment facility. Specific conductance was greater in samples from the Econlockhatchee River near Chuluota (384, 434, and 529 $\mu \mathrm{S} / \mathrm{cm})$, downstream from the treatment facility, than in samples from the Little Econlockhatchee River near Union Park $(165,205$, and $257 \mu \mathrm{S} / \mathrm{cm})$, upstream from the treatment facility. The treatment plant discharges about $15 \mathrm{ft}^{3} / \mathrm{s}$ of reclaimed water to the river (Alan Oyler, City of Orlando, oral commun., 2002). Discharge of the Econlockhatchee River during sample collection ranged from 42 to $61 \mathrm{ft}^{3} / \mathrm{s}$. At times of low flow, reclaimed water can account for nearly one-third of the discharge of the Econlockhatchee River, which probably affects major-ion concentrations in the river. 
Eight stream sites in and around Orange County had water-quality data beginning in the 1960s (table 14). The ranges of selected constituents at the sites are shown in figures 23 and 24. A number of constituents had a large range of values at several of the stream sites during the periods of record. For example, specific conductance ranged from 33 to $720 \mu \mathrm{S} / \mathrm{cm}$ at the Econlockhatchee River near Chuluota, and from 43 to $395 \mu \mathrm{S} / \mathrm{cm}$ at Reedy Creek near Vineland (U.S. Geological Survey, 2004a). Bicarbonate concentrations ranged from 11 to $112 \mathrm{mg} / \mathrm{L}$ at the Econlockhatchee River near Chuluota and from less than 1 to $91 \mathrm{mg} / \mathrm{L}$ a Reedy Creek near Vineland (U.S. Geological Survey, 2004a). Nutrient concentrations also had large variations in concentrations at a number of sites. Nitrite plus nitrate ranged from less than 0.5 to $6.1 \mathrm{mg} / \mathrm{L}$ at the Econlockhatchee River and from 0.5 to $3.2 \mathrm{mg} / \mathrm{L}$ as nitrogen at Reedy Creek. Phosphorus ranged from 0.03 to $4.9 \mathrm{mg} / \mathrm{L}$ at the Econlockhatchee River and from 0.03 to $2.5 \mathrm{mg} / \mathrm{L}$ at Reedy Creek (U.S. Geological Survey, 2004a).

Values of specific conductance, and concentrations of bicarbonate, sulfate, chloride, nitrite plus nitrate, ammonia plus organic nitrogen, and phosphorus were statistically tested for correlations with mean-daily discharge values at the eight sites using Spearman's rho correlation coefficient (table 15). The correlation was considered significant if the probability of no correlation $(r h o=0)$ was less than 5 percent $(\mathrm{p}<0.05)$. All sites had at least two properties or constituents that correlated with discharge, and for Econlockhatchee River, five of seven properties or constituents correlated with discharge. Most properties or constituents correlated negatively with discharge.

Constituents that increased in concentration with increasing discharge include sulfate (Little Econlockhatchee River), ammonia plus organic nitrogen (Boggy Creek, Bonnet Creek, and Reedy Creek), and phosphorus (Bonnet Creek). Specific conductance was strongly correlated to discharge at the Econlockhatchee River, but was not significantly correlated to discharge at Boggy Creek (fig. 25), the Little Econlockhatchee River, or Cypress Creek. The correlations between specific conductance and discharge were relatively weak (absolute value of rho less than 0.50) at Bonnet Creek, Whittenhorse Creek, and Reedy Creek (table 15). Major-ion concentrations, and hence, specific conductance, typically are diluted by rain events (Helsel and Hirsch, 1992), and therefore, would be expected to have strong negative correlations with discharge. The reason for weak or no correlations at seven of the stream sites is unclear.

Data from four sites (Econlockhatchee River, Boggy Creek, Bonnet Creek, and Whittenhorse Creek) were analyzed for temporal trends in water quality. Quantitative trend analysis was limited to specific conductance, bicarbonate, sulfate, chloride, nitrite plus nitrate nitrogen, ammonia plus organic nitrogen, and phosphorus. Flowadjusted values were used for the water-quality variables that were significantly correlated with discharge. The effect of flow adjustment on specific conductance at the Econlockhatchee River is shown in figure 26. For presentation in figure 26, residuals were added to the median value of specific conductance.

Table 14. Stream sites with historical water-quality data, periods of record, basin sizes, and number of samples.

[Source of basin size, U.S. Geological Survey; source of water-quality data, U.S. Geological Survey and Orange County Environmental Protection Division]

\begin{tabular}{|lrrrr|}
\hline \multicolumn{1}{|c}{ Station name } & $\begin{array}{c}\text { Station } \\
\text { identifier }\end{array}$ & Period of record & $\begin{array}{c}\text { Basin } \\
\text { size, } \\
\text { square } \\
\text { miles }\end{array}$ & $\begin{array}{c}\text { No. } \\
\text { of } \\
\text { samples }\end{array}$ \\
\hline Boggy Creek near Taft & 02262900 & $10 / 27 / 1960-2 / 22 / 2001$ & 83.6 & 111 \\
Bonnett Creek near Vineland & 02264100 & $5 / 23 / 1961-9 / 19 / 2001$ & 44.7 & 120 \\
\hline Cypress Creek near Vineland & 02264000 & $7 / 24 / 1963-9 / 17 / 2001$ & 29.3 & 82 \\
Econlockhatchee River near Chuluota & 02233500 & $5 / 9 / 1966-2 / 6 / 2001$ & 241 & 166 \\
\hline Little Econlockhatchee River near Union Park & 02233200 & $11 / 3 / 1960-2 / 8 / 2001$ & 27.1 & 33 \\
Reedy Creek near Vineland & 02266300 & $5 / 23 / 1961-9 / 18 / 2001$ & 84.6 & 161 \\
\hline Shingle Creek near Kissimmee Airport & 02263800 & $8 / 21 / 1962-2 / 28 / 2001$ & 89.2 & 63 \\
Whittenhorse Creek near Vineland & 02266200 & $10 / 23 / 1968-9 / 17 / 2001$ & 12.4 & 64 \\
\hline
\end{tabular}



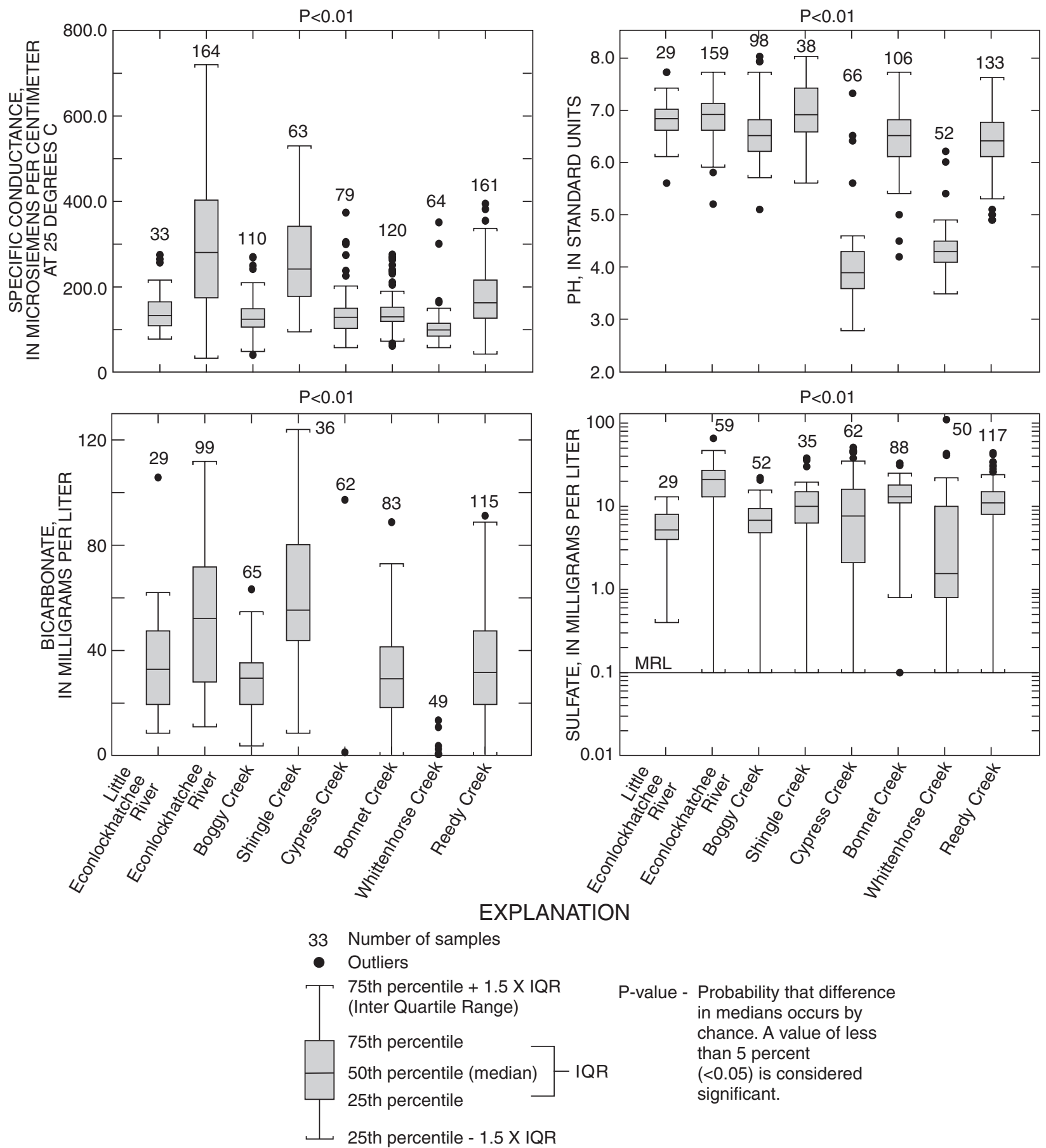

P-value - Probability that difference in medians occurs by chance. A value of less than 5 percent $(<0.05)$ is considered significant.

$M R L=$ Method reporting limit

Source of data: U.S. Geological Survey, City of Orlando Stormwater Utility Bureau, and Orange County Environmental Protection Division

Figure 23. Distribution of specific conductance, $\mathrm{pH}$, and concentrations of bicarbonate and sulfate in historical samples for selected streams, 1960-2001. 

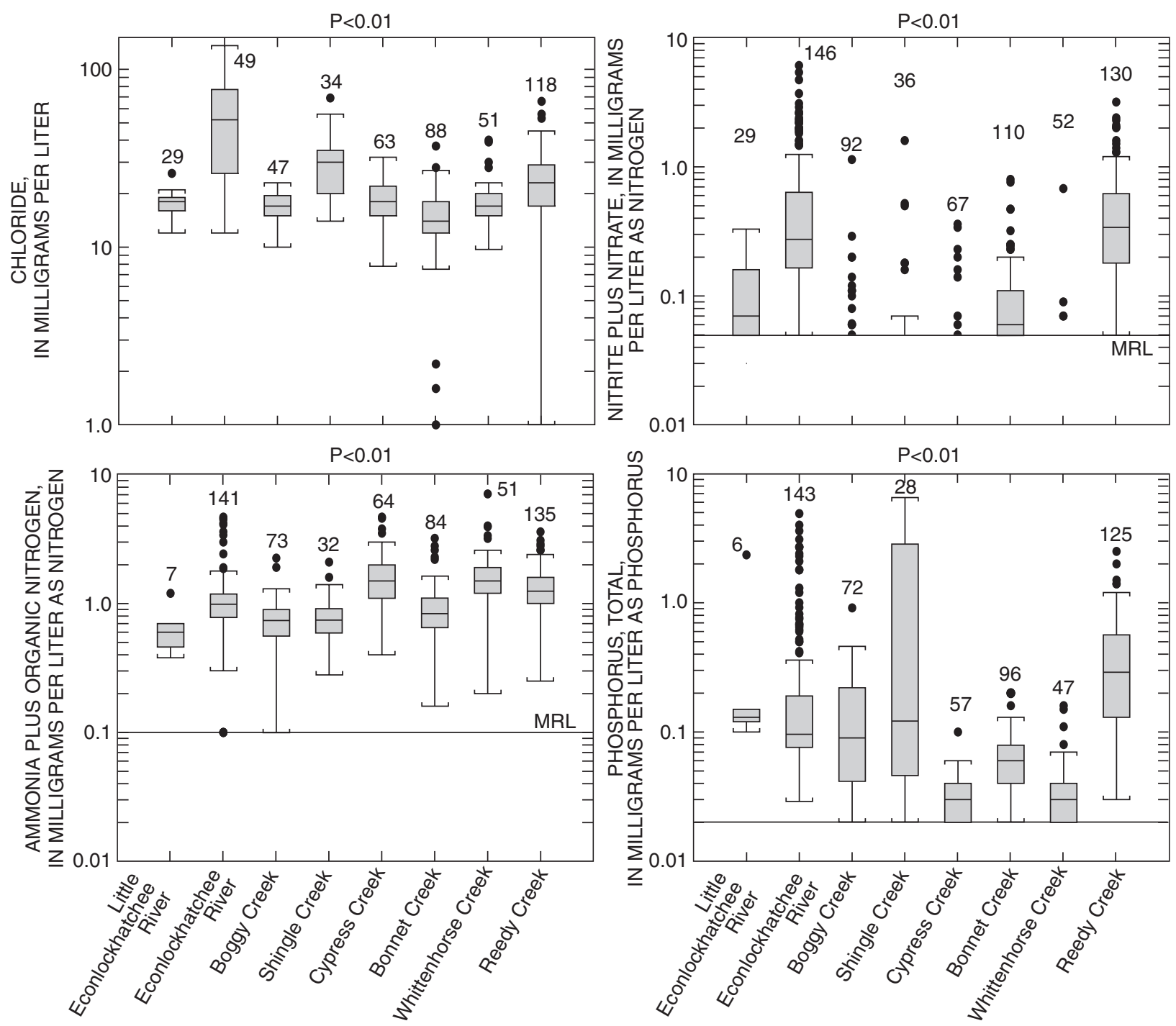

29 Number of samples

- Outliers

T 75th percentile + 1.5 X IQR (Inter Quartile Range)

75th percentile 50th percentile (median)

P-value - Probability that difference in medians occurs by chance. A value of less than 5 percent $(<0.05)$ is considered 25th percentile significant.

25th percentile - 1.5 X IQR

$\mathrm{MRL}=$ Method reporting limit

Source of data: U.S. Geological Survey, City of Orlando Stormwater Utility Bureau, and Orange County Environmental Protection Division

Figure 24. Distribution of chloride, nitrite plus nitrate, ammonia plus organic nitrogen, and total phosphorus in historical samples for selected streams, 1960-2001. 
Table 15. Relation between water-quality properties or constituents and streamflow at selected streams in Orange County.

[The sign of the Spearman rho coefficient indicates if the property or constituent value increases with increasing discharge (positive) or decreases with increasing discharge (negative). The p-value, given in parentheses, is the probability of no relation between property or constituent. A probability of 0.05 or less is taken as evidence of a significant relation and is given in bold type. $<$, less than; ${ }^{*}$, less than 10 samples]

\begin{tabular}{|c|c|c|c|c|c|c|c|}
\hline \multirow[b]{2}{*}{ Station name and identifier } & \multicolumn{7}{|c|}{ Spearman's rho correlation coefficient and p-value } \\
\hline & $\begin{array}{c}\text { Specific } \\
\text { conductance }\end{array}$ & Bicarbonate & Sulfate & Chloride & $\begin{array}{l}\text { Nitrite plus } \\
\text { nitrate }\end{array}$ & $\begin{array}{c}\text { Ammonia } \\
\text { plus organic } \\
\text { nitrogen }\end{array}$ & Phosphorus \\
\hline Boggy Creek (02262900) & $-0.11(p=.26)$ & $0.09(\mathrm{p}=.45)$ & $0.18(\mathrm{p}=.19)$ & $-0.26(\mathrm{p}=.08)$ & $0.15(\mathrm{p}=.14)$ & $\mathbf{0 . 3 5}(\mathrm{p}<.01)$ & $\mathbf{- 0 . 1 9}(\mathrm{p}=.02)$ \\
\hline Bonnett Creek (02264100) & $-.33(\mathrm{p}<.01)$ & $-.33(\mathrm{p}<.01)$ & $.18(\mathrm{p}=.10)$ & $.08(\mathrm{p}=.46)$ & $.17(\mathrm{p}=.07)$ & $.48(\mathrm{p}<.01)$ & $.32(\mathrm{p}<.01)$ \\
\hline Cypress Creek (02264000) & $-.18(\mathrm{p}=.11)$ & $-.38(\mathrm{p}<.01)$ & $.17(\mathrm{p}=.19)$ & $-.04(\mathrm{p}=.77)$ & $-.02(\mathrm{p}=.89)$ & $-.15(\mathrm{p}=.24)$ & $-.27(\mathrm{p}=.04)$ \\
\hline $\begin{array}{l}\text { Little Econlockhatchhee River } \\
\quad(02233200)\end{array}$ & $-.108(\mathrm{p}=.54)$ & $-.33(\mathrm{p}=.08)$ & $.43(p=.02)$ & $-.48(\mathrm{p}=.01)$ & $.2(\mathrm{p}=.29)$ & $*$ & $*$ \\
\hline Reedy Creek (02266300) & $-.37(\mathrm{p}<.01)$ & $-.37(\mathrm{p}<.01)$ & $-.04(\mathrm{p}=.68)$ & $-.17(\mathrm{p}=.06)$ & $-.05(\mathrm{p}=.60)$ & $.52(\mathrm{p}<.01)$ & $-.18(\mathrm{p}=.04)$ \\
\hline Shingle Creek (02263800) & $-.36(\mathrm{p}<.01)$ & $-.32(\mathrm{p}=.06)$ & $-.28(\mathrm{p}=.10)$ & $-.51(\mathrm{p}<.01)$ & $-.21(\mathrm{p}=.22)$ & $.07(\mathrm{p}=.70)$ & $.05(\mathrm{p}=.81)$ \\
\hline Whittenhorse Creek (02266200) & $-.06(\mathrm{p}=.59)$ & $-.44(\mathrm{p}<.01)$ & $-.01(\mathrm{p}=.95)$ & $-.32(\mathrm{p}=.02)$ & $.10(\mathrm{p}=.46)$ & $-.11(\mathrm{p}=.39)$ & $-.13(\mathrm{p}=.35)$ \\
\hline
\end{tabular}

Concentrations of properties or constituents and values of residuals were analyzed for temporal trends using Kendall's tau. The trend was considered significant if the probability of no correlation $($ rho $=0)$ was less than 5 percent $(\mathrm{p}<0.05$; table 16$)$. All four sites had significant trends in at least two of the seven properties or constituents. At Boggy Creek, concentrations of five properties or constituents had significant temporal trends (table 16). Values of specific conductance and concentrations of chloride increased at Boggy Creek, Bonnet Creek, and Whittenhorse Creek. Bicarbonate concentrations increased at the Econlockhatchee River, Boggy Creek, and Bonnet Creek (fig. 27). Sulfate concentrations increased at Boggy Creek (fig. 28). Concentrations of nitrite plus nitrate and ammonia plus organic nitrogen decreased at the Econlockhatchee River (fig. 29).

Phosphorus concentrations significantly decreased at the Econlockhatchee River and Boggy Creek (table 16; fig. 29).

Decreasing nitrate plus nitrite nitrogen and total phosphorus concentrations in the Econlockhatchee River near Chuluota probably are the result of the construction of a wastewater treatment facility upstream on the Little Econlockhatchee River. The facility, a tertiary treatment facility that removes nitrogen and phosphorus, was constructed in 1982 and updated in 1987. It replaced several older facilities that discharged effluent into the Econlockhatchee River and its tributaries. The effluent discharging from the facility most likely has lower concentrations of nitrogen and phosphorus than the effluent from the preexisting facilities (Alan Oyler, City of Orlando, oral commun., 2002).

The increase in bicarbonate concentrations at the Econlockhatchee River, which occurred primarily in the 1990s (fig. 27), could result from effluent from the facility and (or) runoff of lawn irrigation water obtained from the carbonate Floridan aquifer system. As noted earlier, effluent from the facility can account for nearly one-third of the discharge of the Econlockhatchee River during low flow conditions. Urban land use in the basin, which includes residential land use, increased from 12 percent in 1977 to more than 27 percent in 1997. An increase in the volume of irrigation runoff would be expected with increasing urbanization. Most of the increase in urban land use occurred in the Little Econlockhatchee River basin, but data were insufficient for trend analysis at that site.

Changes with time also occurred at Boggy Creek. Specific conductance (fig. 26), concentrations of bicarbonate (fig. 27), sulfate (fig. 28), and chloride (fig. 28) increased at Boggy Creek probably as a result of increases in urban land use (fig. 4). Urban and transportation land use in the basin increased from about 36 percent in 1977 to almost 51 percent in 1997. Phosphorus concentrations decreased at Boggy Creek. This decrease appears to span the entire period of record (fig. 29), and probably is related to a decrease in agricultural and range land use from 45 percent in 1977 to less than 19 percent in 1997. 

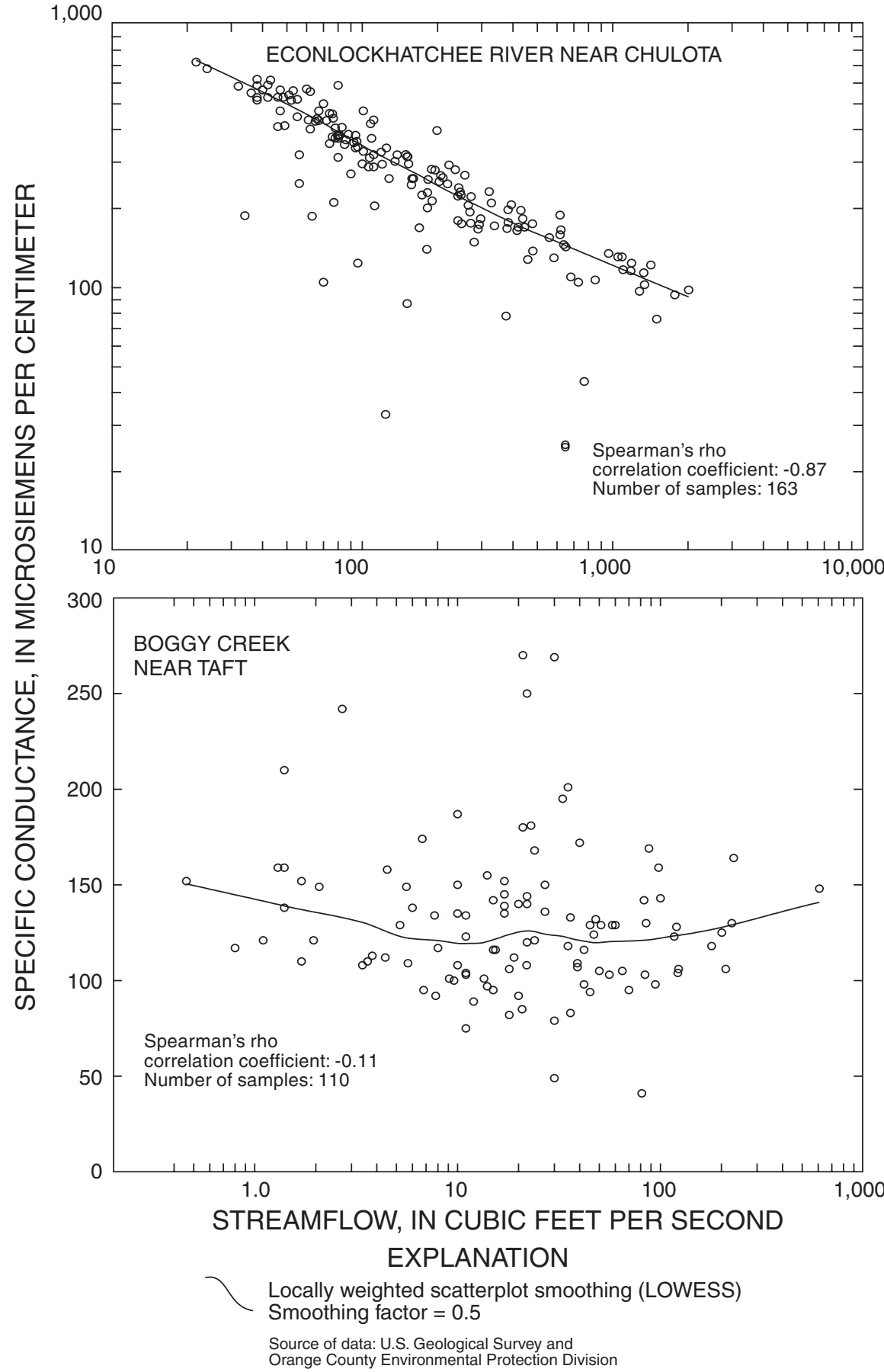

Figure 25. Relation of specific conductance to streamflow for historical samples from the Econlockhatchee River and Boggy Creek, 1960-2001.

Specific conductance (fig. 26) and chloride concentrations (fig. 28) increased at Whittenhorse Creek throughout most of the period of record. The trend could be partially related to the construction of RIBs in the creek basin for disposal of treated wastewater. However, full use of the RIBs did not begin until about 1992, and the trends in both specific conductance and chloride appear to begin at the beginning of the period of record (1968). Changes in land use, such as an increase in transportation and urban land use from less than 2 percent in 1977 to 6 percent in 1997, could be affecting specific conductance and chloride concentrations in Whittenhorse Creek.

Data from Reedy Creek were analyzed with a different method because the creek receives effluent from a wastewater treatment facility. The data were grouped into three periods of record: the period prior to wastewater discharge (period 1, pre-1972), the period of wastewater discharge (period 2, 1972-91), and the period after 

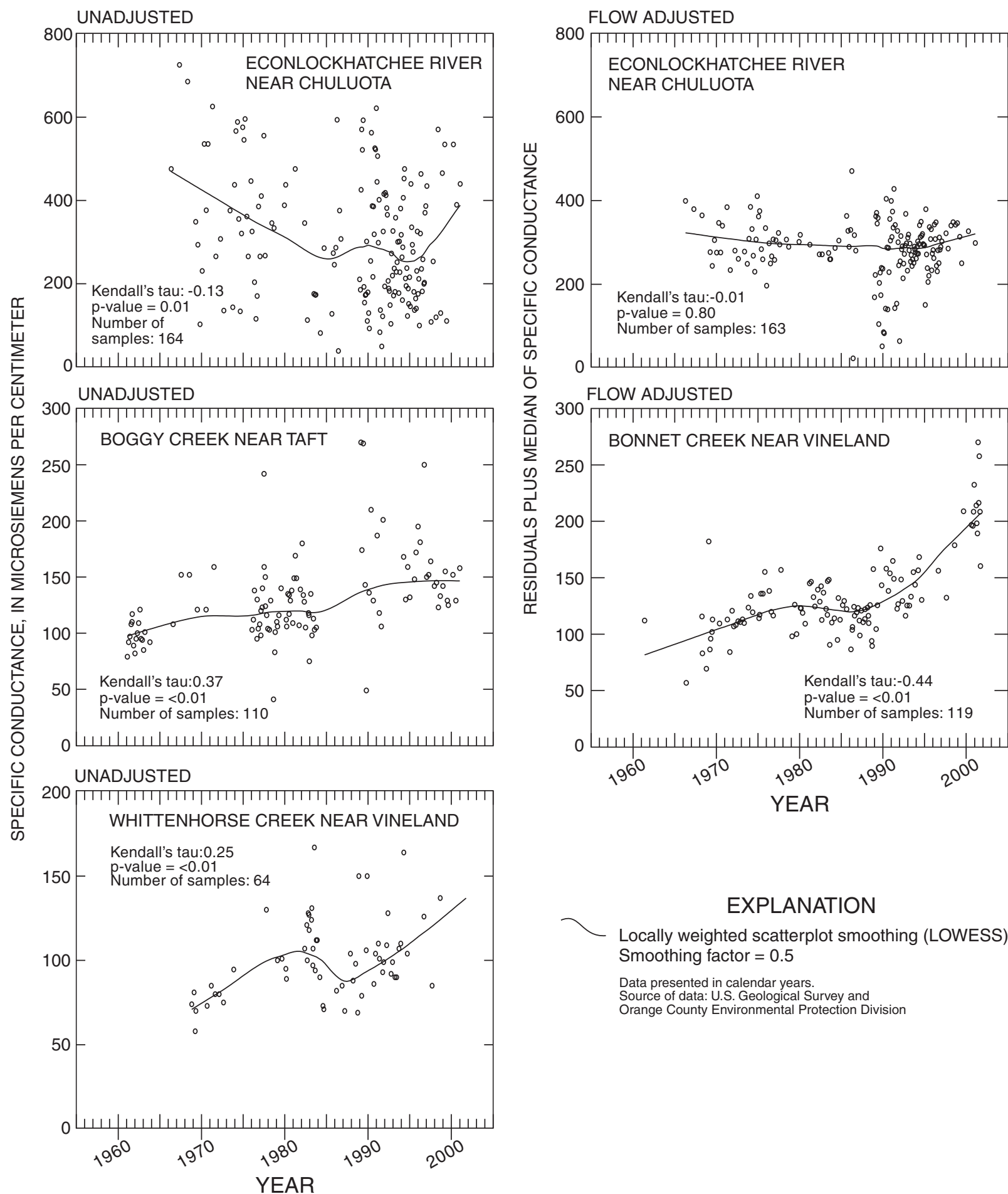

\section{EXPLANATION}

Locally weighted scatterplot smoothing (LOWESS) Smoothing factor $=0.5$

Data presented in calendar years.

Source of data: U.S. Geological Survey and Orange County Environmental Protection Division

Figure 26. Relation of specific conductance to time in samples for the Econlockhatchee River and Boggy, Bonnet, and Whittenhorse Creeks. 
Table 16. Temporal trends in water quality at selected sites in Orange County.

[The Kendall's Tau is a test statistic based on relation of the water-quality constituent or property with time. A positive Kendall Tau value indicates an increase in property or constituent value with time, and a negative value indicates a decrease in property or constituent value with time. The $p$-value, given in parentheses, is the probability that a pattern of increasing or decreasing property or constituent value could result from a trendless set of data due to chance. A probability of 0.05 or less is taken as evidence of a significant trend and is given in bold type. $<$, less than, ${ }^{*}$, more than 75 percent of data were below detection limit]

\begin{tabular}{|c|c|c|c|c|c|c|c|c|}
\hline \multirow[b]{2}{*}{$\begin{array}{l}\text { Station name and } \\
\text { identifier }\end{array}$} & \multirow[b]{2}{*}{$\begin{array}{c}\text { Flow } \\
\text { adjustment }\end{array}$} & \multicolumn{7}{|c|}{ Kendall's Tau and p-value } \\
\hline & & $\begin{array}{c}\text { Specific } \\
\text { conductance }\end{array}$ & Bicarbonate & Sulfate & Chloride & $\begin{array}{l}\text { Nitrite } \\
\text { plus } \\
\text { nitrate }\end{array}$ & $\begin{array}{c}\text { Ammonia } \\
\text { plus organic } \\
\text { nitrogen }\end{array}$ & Phosphorus \\
\hline \multirow{2}{*}{$\begin{array}{l}\text { Boggy Creek } \\
(02262900)\end{array}$} & Unadjusted & $0.37(\mathbf{p}<.01)$ & $0.39(\mathrm{p}<.01)$ & $0.28(\mathrm{p}<.01)$ & $0.32(\mathrm{p}<.01)$ & $0.02(\mathrm{p}=.76)$ & $-0.08(\mathrm{p}=.31)$ & $-0.62(p<.01)$ \\
\hline & Flow adjusted & & & & & & $-.14(\mathrm{p}=.09)$ & $-.61(p<.01)$ \\
\hline $\begin{array}{r}\text { Bonnet Creek } \\
(02264100)\end{array}$ & Unadjusted & $.34(\mathbf{p}<.01)$ & $.07(\mathrm{p}=.36)$ & $-.08(\mathrm{p}=.29)$ & $.55(\mathbf{p}<.01)$ & $-.11(\mathrm{p}=.07)$ & $-.02(p=.76)$ & $-.11(\mathrm{p}=.12)$ \\
\hline \multirow{2}{*}{$\begin{array}{l}\text { Econlockhatchee River } \\
\text { (02233500) }\end{array}$} & Unadjusted & $-.13(p=.01)$ & $.04(\mathrm{p}=.55)$ & $-.05(\mathrm{p}=.57)$ & $-.11(\mathrm{p}=.25)$ & $-.50(p<.01)$ & $-.33(p<.01)$ & $-.60(p<.01)$ \\
\hline & Flow adjusted & $-.01(\mathrm{p}=.80)$ & $.39(p<.01)$ & $.08(\mathrm{p}=.37)$ & $-.11(\mathrm{p}=.25)$ & $-.45(p<.01)$ & & \\
\hline \multirow{2}{*}{$\begin{array}{l}\text { Whittenhorse Creek } \\
\quad(02266200)\end{array}$} & Unadjusted & $.25(p<.01)$ & $*$ & $-.03(\mathrm{p}=.74)$ & $.30(\mathbf{p}<.01)$ & $*$ & $<-.01(\mathrm{p}=.98)$ & $-.09(\mathrm{p}=.35)$ \\
\hline & Flow adjusted & & $*$ & & $.37(p<.01)$ & $*$ & & \\
\hline
\end{tabular}

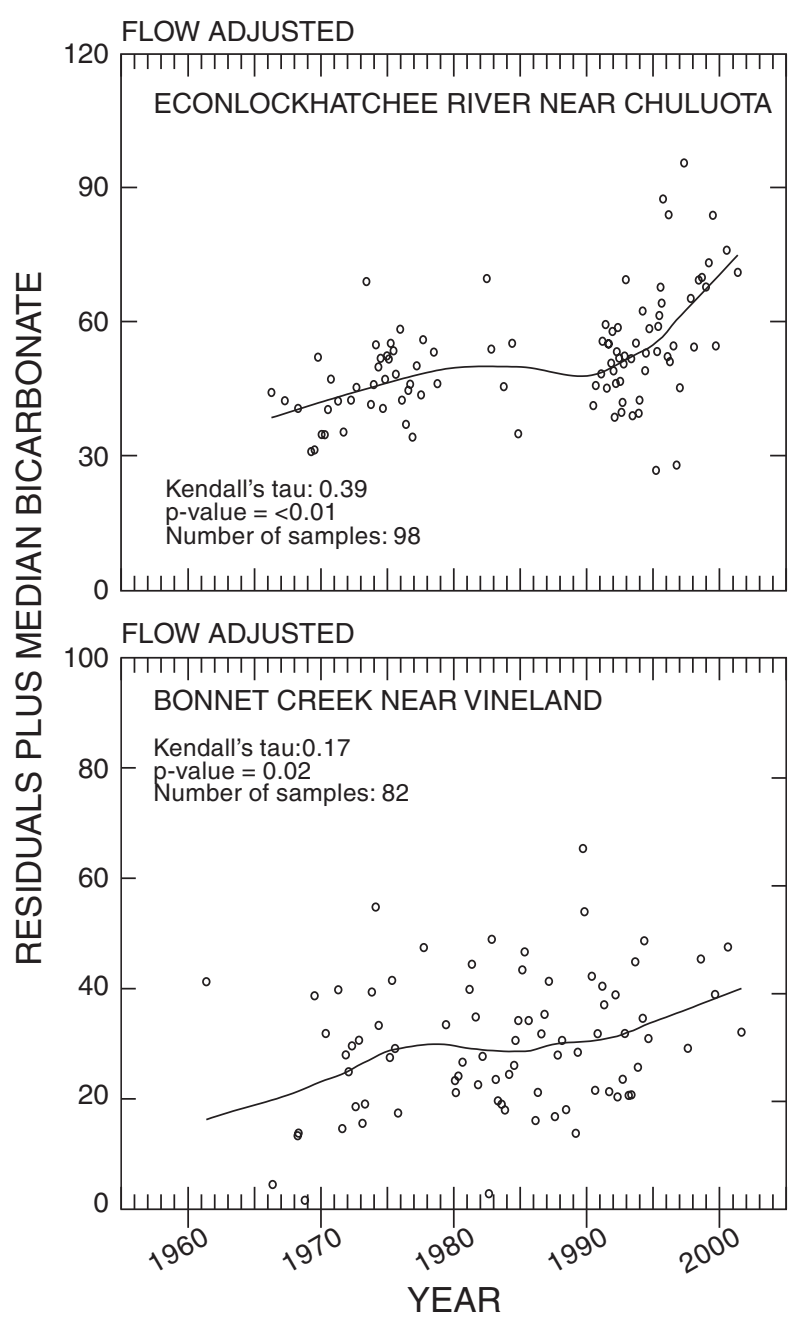

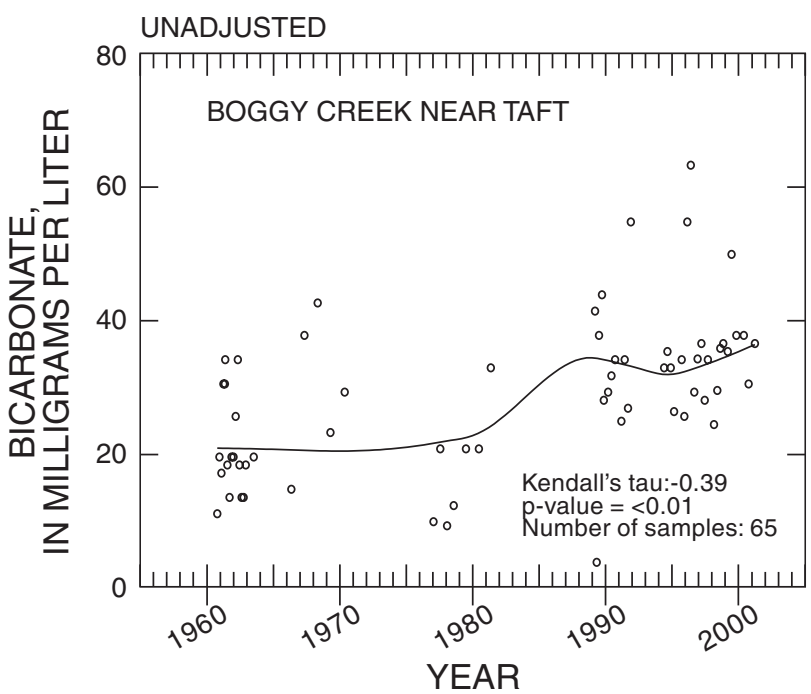

\section{EXPLANATION}

Locally weighted scatterplot smoothing (LOWESS) Smoothing factor $=0.5$

Data presented in calendar years.

Source of data: U.S. Geological Survey and Orange County Environmental Protection Division

Figure 27. Relation of bicarbonate concentrations to time in samples for the Econlockhatchee River and Boggy and Bonnet Creeks. 

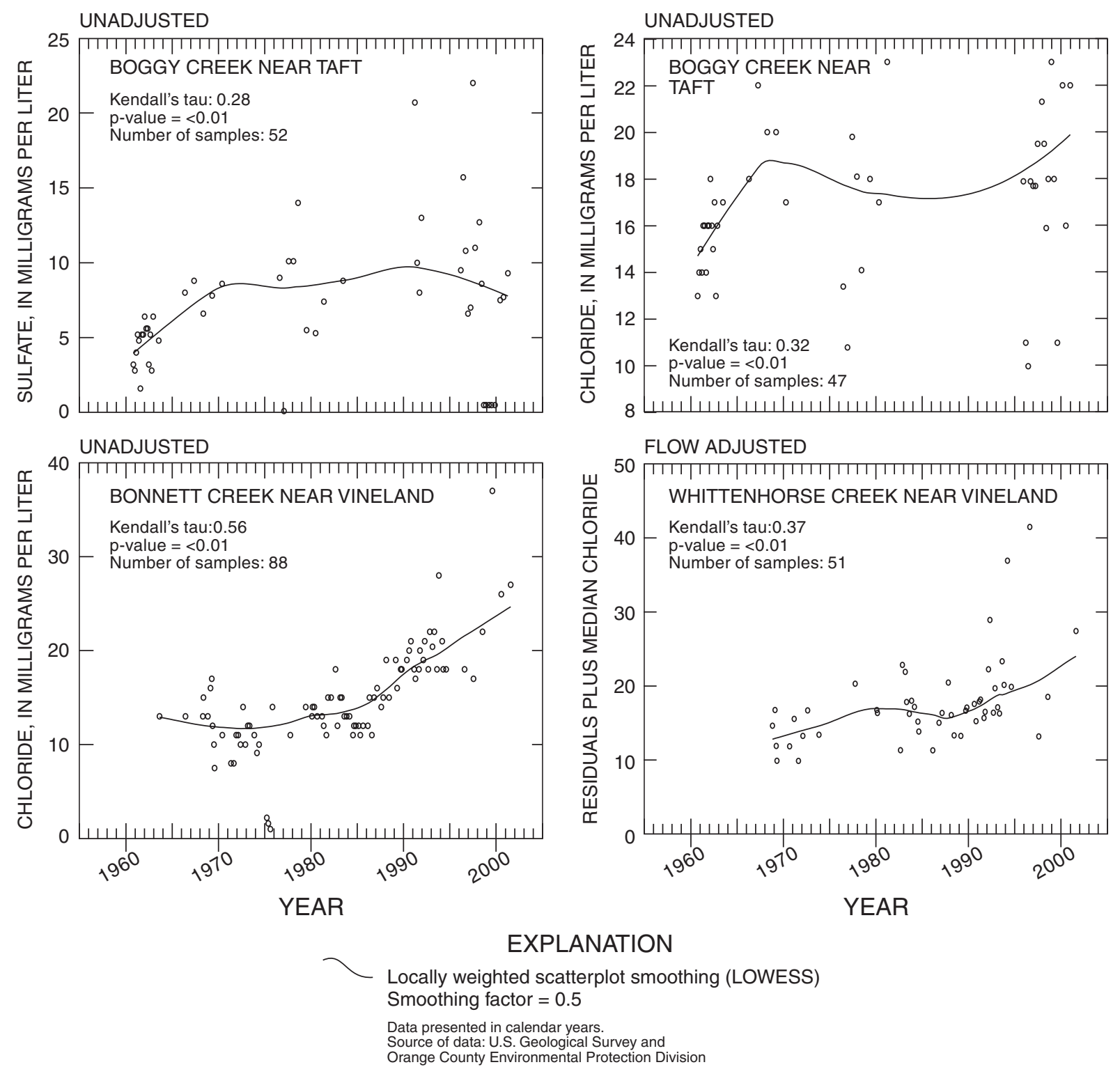

Figure 28. Relation of sulfate concentrations to time in samples for Boggy Creek, and relation of chloride concentrations to time in samples for Boggy, Bonnet, and Whittenhorse Creeks.

wastewater discharge (period 3, 1992-2001). A nonparametric statistical test (Kruskal-Wallis) was used to analyze differences in median concentrations of constituents for the three periods.

The Kruskal-Wallis test indicated that significant differences did exist in median values of specific conductance and concentrations of bicarbonate, sulfate, chloride, nitrite plus nitrate, ammonia plus organic nitrogen, and phosphorus among the three periods. The Kruskal-Wallis test does not identify which periods are significantly higher than the other periods. However, the highest median values and concentrations seemed to occur during period 2

(fig. 30). These relatively high values and concentrations probably are related to the discharge of treated wastewater into Reedy Creek from 1972-91. Median values of specific conductance and concentrations of sulfate, chloride, and nitrite plus nitrate also seem to be greater during period 3 than during period 1 , indicating that concentrations of these constituents did not return to predevelopment levels after the discontinuation of treated wastewater discharge into Reedy Creek. This apparent lag time could result from the storage of sulfate, chloride, and nitrite plus nitrate in the sediments of Reedy Creek during period 2. The extensive wetlands in the Reedy Creek basin could be storing the constituents from earlier waste water discharge. These constituents presently (2004) could be slowly leaching back into the water column, thereby preventing the return of their concentrations to predevelopment levels. 


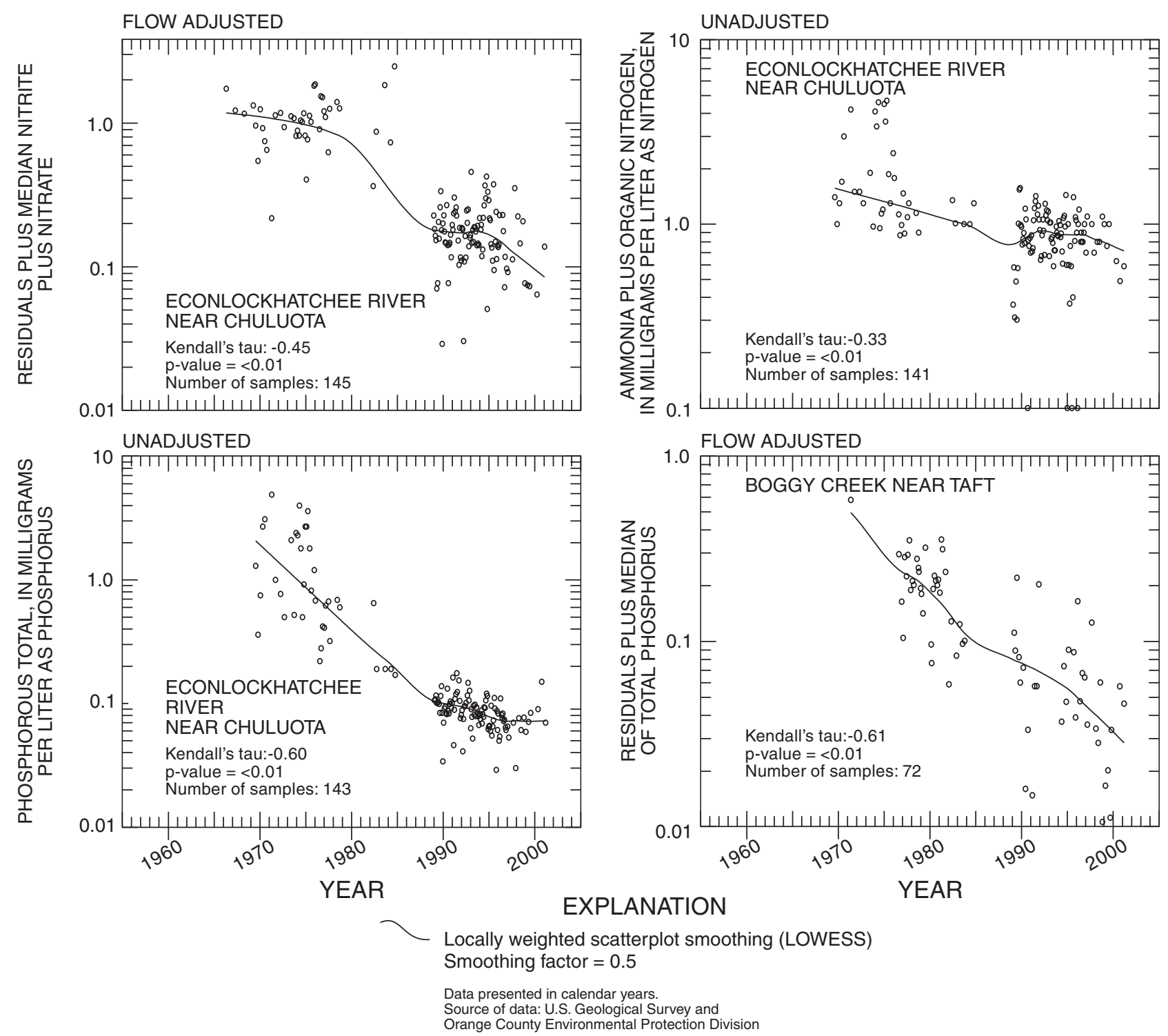

Figure 29. Relation of nitrite plus nitrate and ammonia plus organic nitrogen concentrations to time in samples for the Econlockhatchee River, and relation of total phosphorus concentrations to time in samples for the Econlockhatchee River and Boggy Creek.

The trends in water-quality constituents in Reedy Creek also could be affected by land-use changes. Urban land use in the basin increased from 4.8 percent in 1977 to 8.1 percent in 1997. Urban land use has continued to increase to the present (2004) and probably is greater than 8.1 percent. Furthermore, most of this urban development is tourist attractions, which are equivalent to high-density urban land use. Hence, the impact on water quality could be relatively large in comparison to the size of the urban land-use area.

Water-quality data for Shingle Creek were not analyzed for temporal trends. Previous investigations indicated that there were substantial changes in water quality in Shingle Creek as a result of removal of wastewater discharge into the stream. Phosphorus loads carried by Shingle Creek decreased by 62 percent, and nitrogen loads decreased by 39 percent after removal of the wastewater in 1987 (O’Dell, 1994).

\section{Major lons and Nutrients in Lakes}

A number of surface-water bodies in and around Orange County are listed as impaired in the State of Florida's 303(d) list (Florida Department of Environmental Protection, 2002). Sites in the 303(d) list have quality of water that does not support designated uses. Lake Apopka, Lake Beauclair, Lake Carlton, and Lake Olive are in the 303(d) list. 

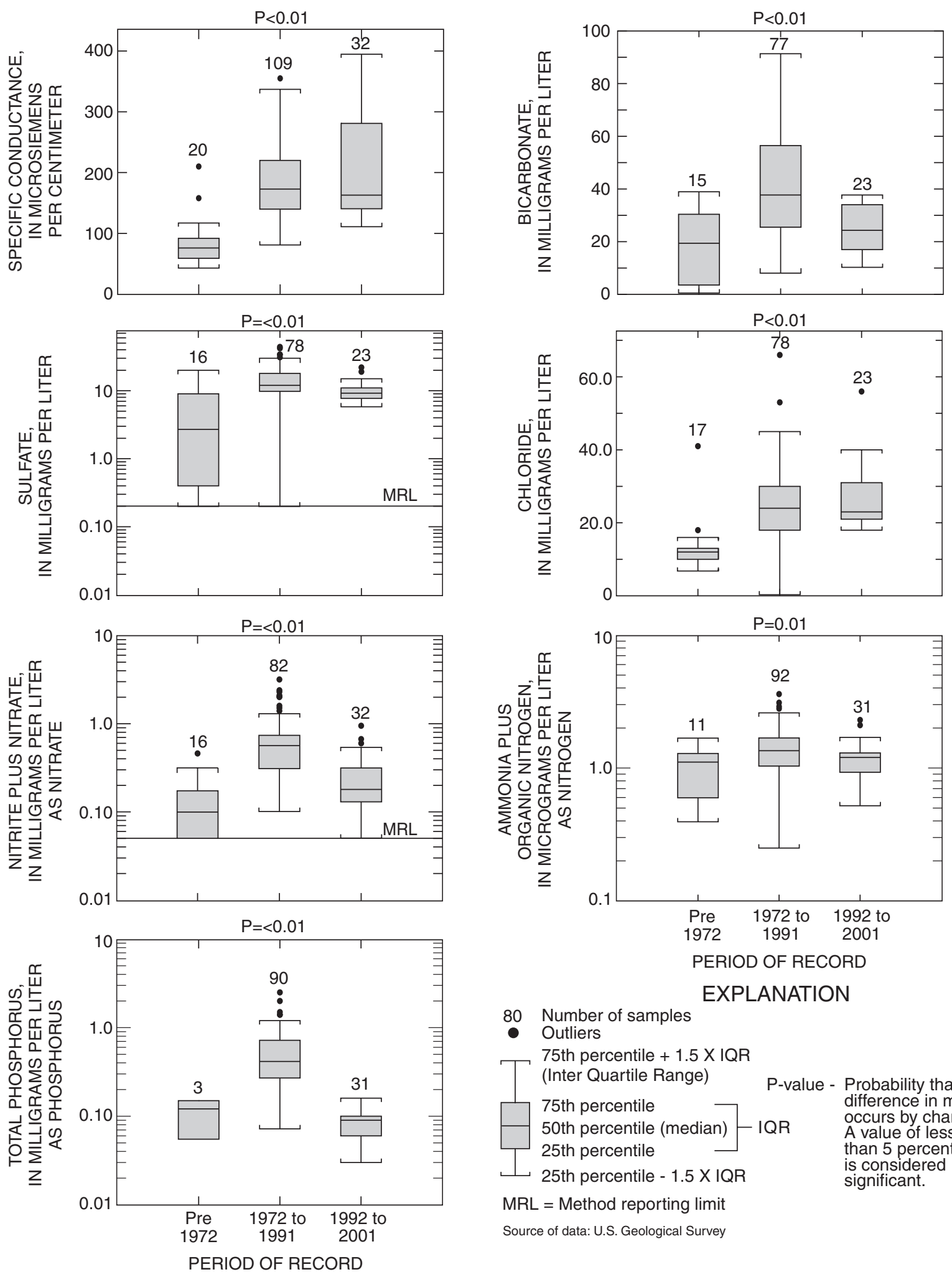
80 Number of samples
- Outliers
$7 \begin{aligned} & \text { 75th percentile + 1.5 X IQR } \\ & \text { (Inter Quartile Range) }\end{aligned}$ P-value - Probability that
75th percentile 50th percentile (median) - IQR
25th percentile A value of less
than 5 percent $(<0.05)$
25th percentile - 1.5 X IQR is considered

$M R L=$ Method reporting limit

Source of data: U.S. Geological Survey

Figure 30. Distribution of specific conductance, and concentrations of bicarbonate, sulfate, chloride, nitrite plus nitrate, ammonia plus organic nitrogen, and total phosphorus in historical samples for Reedy Creek. 
Lake Apopka is noteworthy because it is considered Florida's most polluted large lake (St. Johns River Water Management District, 2004a). Sources of nutrient-rich contamination have included runoff from about 20,000 acres of farmlands, discharge of treated wastewater from shoreline communities, and discharges from citrus processing plants. This addition of nutrients changed Lake Apopka from a popular recreational lake before the late 1940s to a pea-green lake with a thick layer of bottom muck and little fishing or other recreation potential. Additionally, outflow from Lake Apopka contributes significant phosphorus loads to lakes downstream in the Ocklawaha Chain of Lakes. The sources of nutrient inflow to Lake Apopka no longer exist and the lake is presently (2004) being restored by St. Johns River Water Management District according to the Lake Apopka Restoration Act of 1985 and Florida's Surface Water Improvement and Management (SWIM) Act of 1987. An overview of the restoration project is available on the SJRWMD website (St. Johns River Water Management District, 2004b).

There are some regional patterns in lake water quality in Orange County. These regional patterns probably are due to several factors that are characteristic of the regions, including seepage rates of ground water to or from lakes, quality of ground water seepage, land use, and types of soils and vegetation around the lakes. For example, in areas where the potentiometric surface of the Upper Floridan aquifer exceeds the lakes water-surface elevation, lakes may contain relatively hard water if they receive water from the Upper Floridan aquifer, either from spring flow or from diffuse upward leakage. Conversely, lakes in ridge areas that are isolated from the Upper Floridan aquifer may contain soft water and be vulnerable to acidification by atmospheric deposition (Brezonik and others, 1980). Lakes in agricultural areas may receive runoff or ground-water seepage that is enriched in nutrients and other constituents because of fertilizer application.

A summary of lake water quality by the lake regions defined by the USEPA (fig. 3) is given in Griffith and others (1997), and is based on data from several sources collected from 1979-96. Griffith and others (1997) data indicated the general types of lake water quality that are characteristic of the lake regions, although the water quality may vary widely within each region. One of the most unique water-quality characteristics of the lake regions is the low median $\mathrm{pH}$ value and high median water color of Osceola Slope lakes (fig. 31). The low pH and relatively low median specific conductance are indications that the region is isolated from the Upper Floridan aquifer. The high median water color indicates that the low $\mathrm{pH}$ values may result from tannins leached from vegetative debris, rather than from atmospheric deposition into unbuffered lake waters. Another notable characteristic of the Osceola Slope lakes is that Secchi-disk clarity tends to be relatively low, probably as a result of the high-water color rather than high chlorophyll- $a$ concentrations. Chlorophyll- $a$ concentrations in Osceola Slope lakes tend to be relatively low.

The highest median total phosphorus concentrations and chlorophyll- $a$ occur in lakes in the Central Valley region and the Orlando Ridge region (fig. 31). Variation in total phosphorus and chlorophyll- $a$ concentrations among lakes in these two lake regions also is high, as shown by the relatively large differences between 75 th and 25 th percentile concentrations. These relatively high concentrations probably are related to land use. The Central Valley (fig. 3) contains relatively large amounts of agricultural lands that may be a source of phosphorus to lakes. Phosphorus enrichment could result in high chlorophyll- $a$ levels. The Orlando ridge area contains mostly urban land use. Use of fertilizers on lawns and recreational areas may contribute to phosphorus enrichment of lakes in the area, and subsequent high chlorophyll- $a$ levels.

Water quality of lakes in the Dr. Phillips Ridge lake region is unique among the other six lake regions in Orange County because of the low phosphorus and chlorophyll- $a$ concentrations, and the high Secchi-disk clarity, all desirable water-quality conditions from an aesthetic and recreational viewpoint. The relatively high $\mathrm{pH}$ and specific conductance of the lakes in the Dr. Phillips Ridge region suggest that the lakes could be affected by discharge from the Upper Florida aquifer. However, land-surface altitude in this area is 100-170 ft above NGVD 29 (Griffith and others, 1997); the region is a recharge area for the upper Floridan aquifer.

Data for 2000-01 collected by USGS, Orange County, and the City of Orlando indicate that a large range of waterquality conditions exist in the lakes of Orange County. For example, specific conductance ranged from 57 to $1,185 \mu \mathrm{S} / \mathrm{cm}$, with a median of $202 \mu \mathrm{S} / \mathrm{cm}$ (table 17). There is no clear areal pattern in specific conductance (fig. 32). For example, lakes with relatively high specific conductance $(176-250 \mu \mathrm{S} / \mathrm{cm})$ and lakes with relatively low specific conductance $(57-175 \mu \mathrm{S} / \mathrm{cm})$ both occur in the urbanized areas of central Orange County. The four lakes with specific conductance greater than $500 \mu \mathrm{S} / \mathrm{cm}$ are scattered, with one in southwest Orange County, another in westcentral Orange County, and the other two lakes in southeast Orange County.

Other water-quality indicators and constituents also had wide ranges of values and concentrations in samples from lakes. Values of $\mathrm{pH}$ ranged from 4.6 to 9.6 in samples from lakes (table 17). Concentrations of bicarbonate 

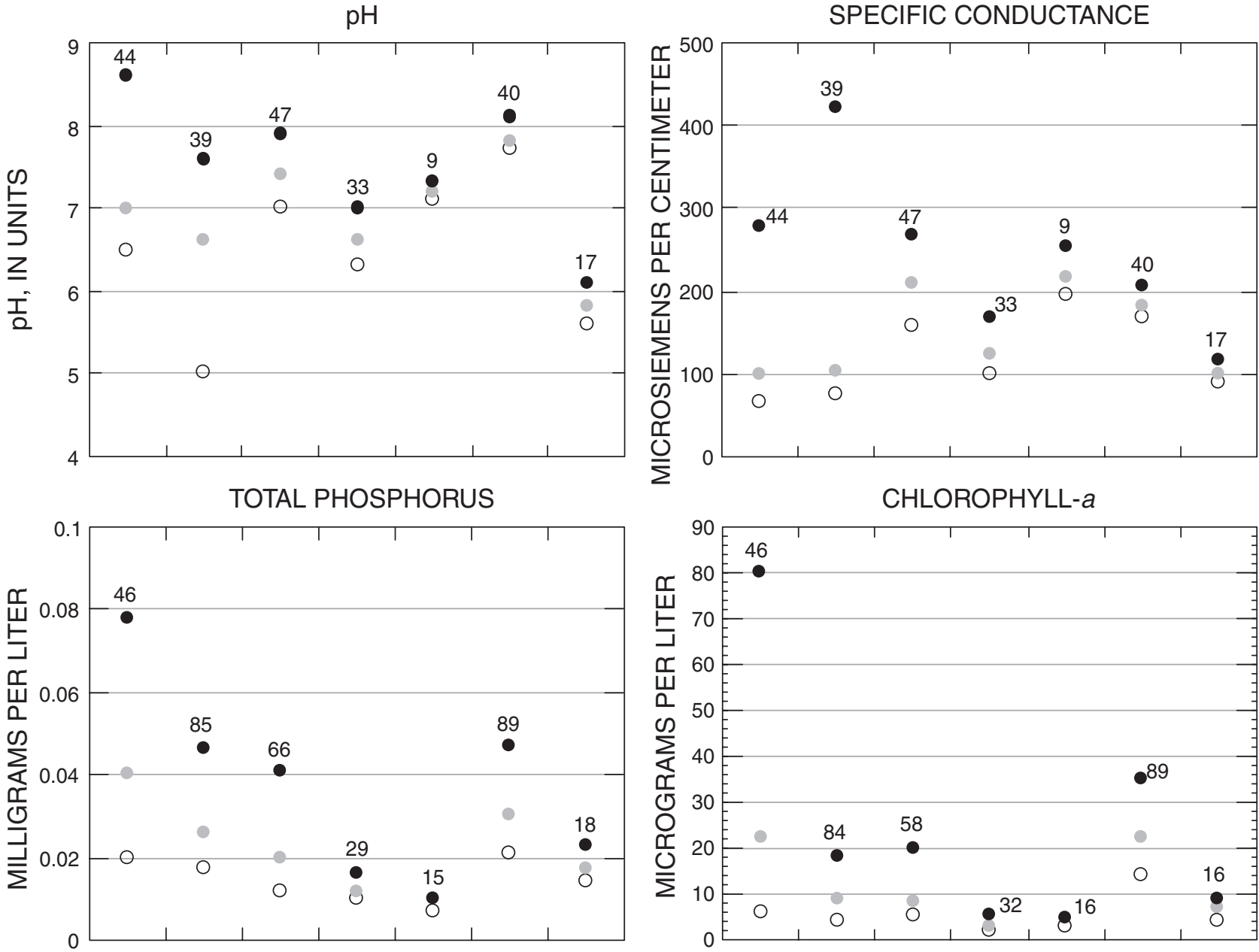

CHLOROPHYLL-a
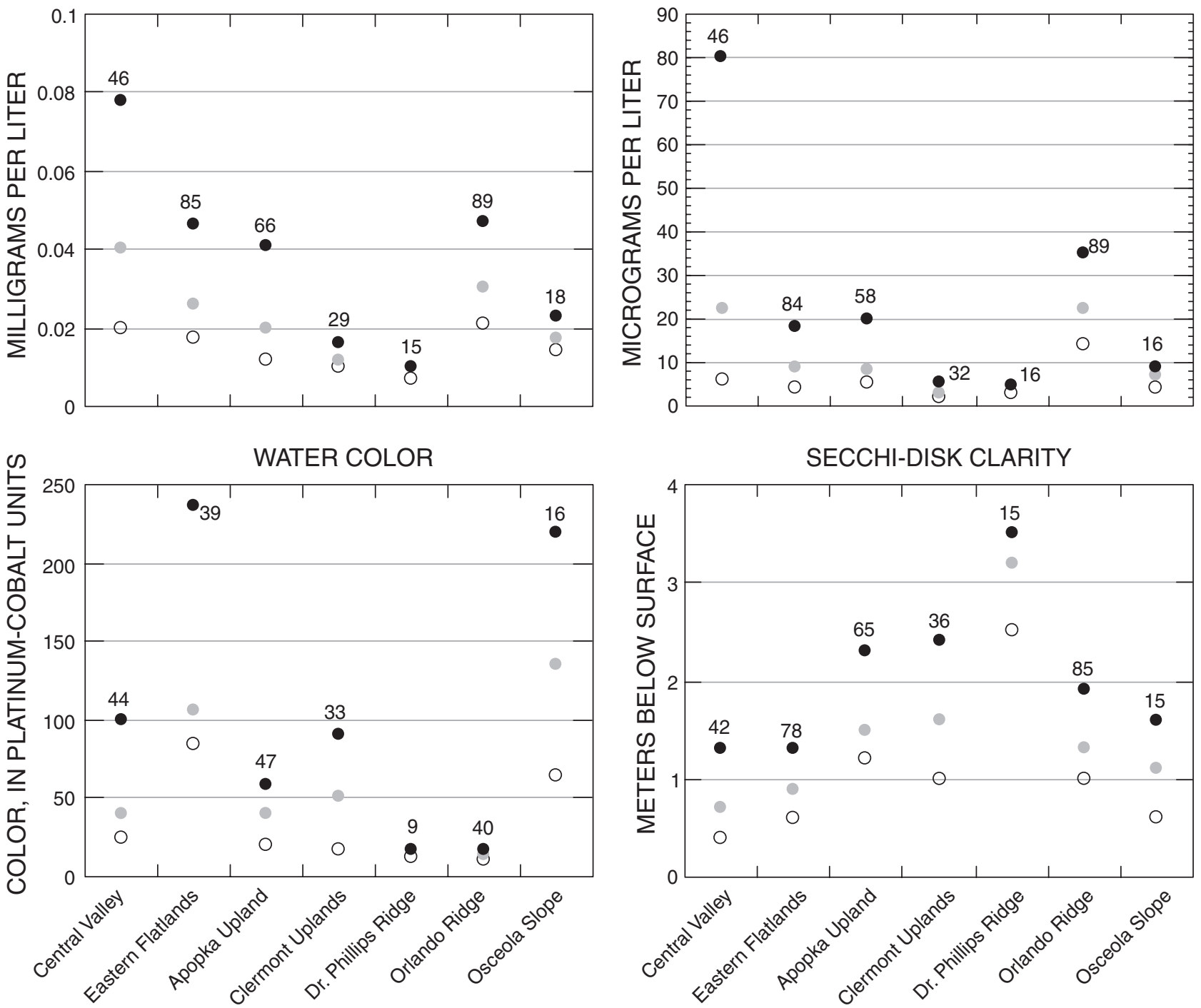

EXPLANATION

33 NUMBER OF LAKES • 75th PERCENTILE - MEDIAN O 25th PERCENTILE

Figure 31. Comparison of lake water quality by lake region. (Data are from Griffith and others, 1997.) 
Table 17. Summary statistics of water-quality indicators and chemical constituents in samples from 140 lakes in Orange County, 2000-01.

[Data source, City of Orlando Stormwater Utility Bureau, Orange County Environmental Protection Division, U.S. Geological Survey.

${ }^{\circ} \mathrm{C}$, degrees Celsius; all units are in milligrams per liter unless otherwise noted; $\mu \mathrm{S} / \mathrm{cm}$, microsiemens per centimeter; $\mu \mathrm{g} / \mathrm{L}$, micrograms per liter; $<$, less than]

\begin{tabular}{|lcccccc|}
\hline \multicolumn{1}{|c}{ Constituent } & $\begin{array}{c}\text { No. } \\
\text { of } \\
\text { samples }\end{array}$ & Minimum & $\begin{array}{c}\text { 25th } \\
\text { percentile }\end{array}$ & Median & $\begin{array}{c}\text { 75th } \\
\text { percentile }\end{array}$ & Maximum \\
\hline Temperature, ${ }^{\circ} \mathrm{C}$ & 422 & 11.7 & 22.1 & 28.2 & 29.9 & 33.4 \\
Specific conductance, $\mu \mathrm{S} / \mathrm{cm}$ & 421 & 57 & 166 & 202 & 240 & 1,185 \\
pH, standard units & 421 & 4.6 & 6.9 & 7.7 & 8.2 & 9.6 \\
Calcium & 191 & 1.6 & 12 & 16 & 22 & 40 \\
Magnesium & 192 & 1.2 & 3.2 & 4.2 & 6.9 & 20.3 \\
\hline Sodium & 192 & $<1.0$ & 9.2 & 12 & 15 & 160 \\
Potassium & 191 & $<1.0$ & 2.5 & 4.2 & 7.8 & 19 \\
Bicarbonate & 431 & $<1.0$ & 27 & 47 & 68 & 169 \\
Sulfate & 218 & $<1.0$ & 14 & 27 & 38 & 81 \\
Chloride & 216 & 9.7 & 17 & 26 & 32 & 290 \\
\hline Nitrite plus nitrate as nitrogen & 426 & $<.05$ & $<.05$ & $<.05$ & $<.05$ & .51 \\
Nitrite as nitrogen & 426 & $<.02$ & $<.02$ & $<.02$ & $<.02$ & .05 \\
Ammonia as nitrogen & 431 & $<.02$ & $<.02$ & .02 & .03 & .53 \\
Ammonia plus organic nitrogen as nitrogen & 428 & $<.2$ & .58 & .79 & 1.1 & 6 \\
Nitrogen, total & 448 & $<.2$ & .58 & .8 & 1.1 & 6 \\
\hline Phosphorus, total & 446 & $<.02$ & $<.02$ & $<.02$ & .04 & .38 \\
Orthophosphate as phosphorus & 427 & $<.02$ & $<.02$ & $<.02$ & $<.02$ & .45 \\
Chlorophyll- $a$, $\mu \mathrm{gg} / \mathrm{L}$ & 447 & $<.5$ & 3.7 & 13 & 27 & 200 \\
\hline
\end{tabular}

ranged from less than 1 to $169 \mathrm{mg} / \mathrm{L}$, sulfate ranged from less than 1 to $81 \mathrm{mg} / \mathrm{L}$, and chloride ranged from 9.7 to 290 mg/L (table 17). National Secondary Drinking Water Regulations for chloride and sulfate specify a maximum concentration of $250 \mathrm{mg} / \mathrm{L}$. Secondary standards are nonenforceable standards set for cosmetic (skin or tooth discoloration) or aesthetic effects (taste, odor, or color) (U.S. Environmental Protection Agency, 2002). The secondary standard for chloride was exceeded in a sample from a pond at Tosohatchee State Reserve $(290 \mathrm{mg} / \mathrm{L}$; appendix D).

Water type in lakes, as related to the major dissolved cations and anions, is variable in Orange County (fig. 33). Reedy Lake and Lake Louise are examples of lakes with sodium-chloride type water. The sodium-chloride water type may result from domestic wastewater seepage into a lake, or from upward leakage of relict seawater through the Upper Floridan aquifer in the eastern part of Orange County. Lake Underhill and Lake Ivanhoe have a calciumbicarbonate water type. This type of water may result from seepage of water from the Upper Floridan aquifer or seepage from the surficial aquifer in areas that were irrigated using water from the Upper Floridan aquifer. Another possible source of calcium-bicarbonate type water may be storm runoff from streets, parking lots, and other concrete features. Other lakes, such as Lake Ola, have a mixed water type, suggesting several different sources of inflow to the lake.

Total nitrogen concentrations ranged from less than 0.2 to $6 \mathrm{mg} / \mathrm{L}$ as nitrogen (table 17). Comparison of concentrations of various forms of nitrogen indicates that most of the nitrogen present in the samples from lakes is in the form of organic nitrogen. For example, concentrations of nitrite and nitrite plus nitrate were less than the reporting limits ( 0.02 and $0.05 \mathrm{mg} / \mathrm{L}$, respectively) in at least 75 percent of the samples from lakes. Ammonia plus organic nitrogen ranged from less than 0.2 to $6.0 \mathrm{mg} / \mathrm{L}$ as nitrogen. However, concentrations of ammonia were less than or equal to the reporting limit of $0.02 \mathrm{mg} / \mathrm{L}$ as nitrogen (table 17) in about 50 percent of the samples from lakes. There is little areal pattern in total nitrogen occurrence in Orange County lakes. Lakes with total nitrogen 


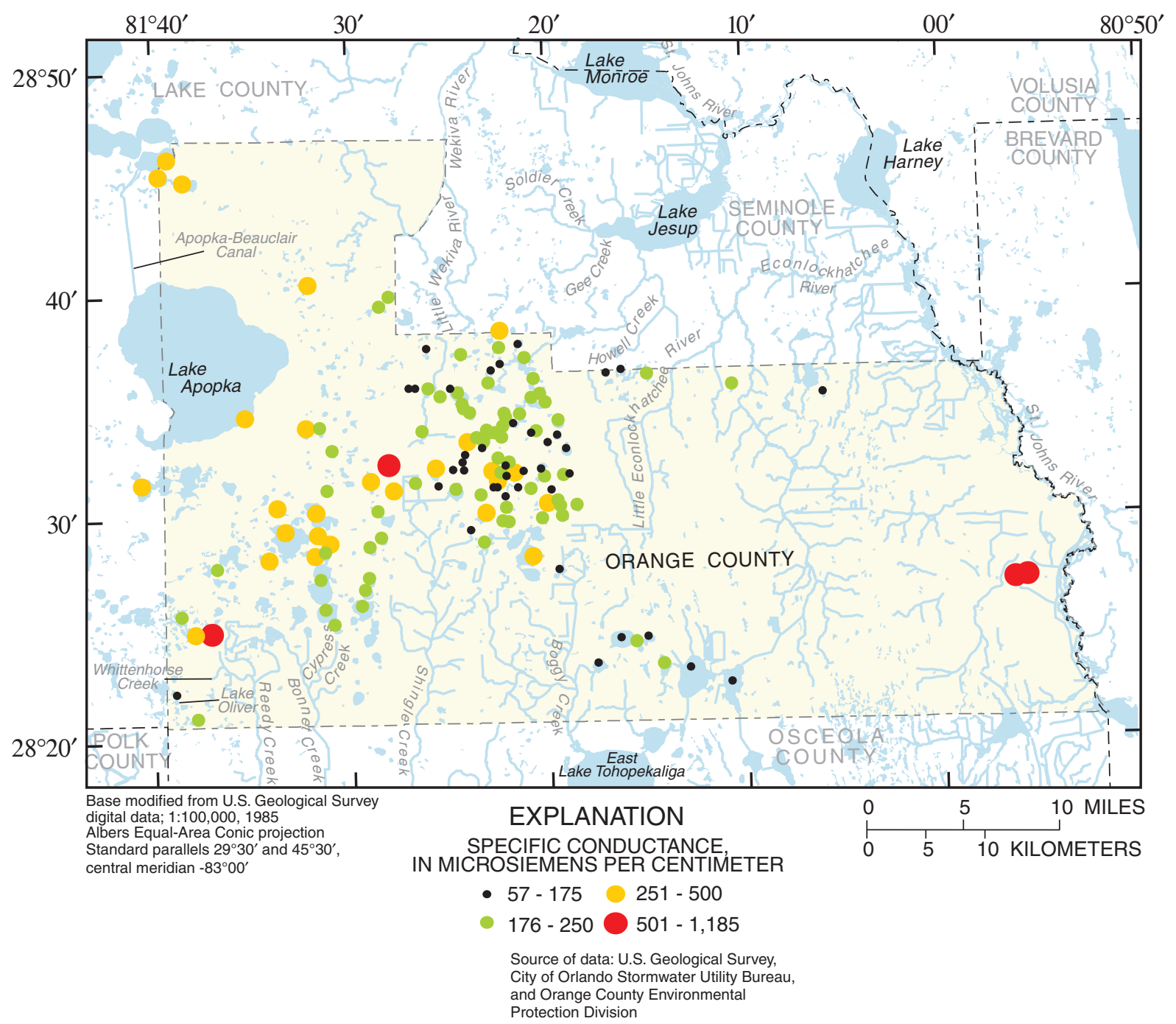

Figure 32. Specific conductance for selected lakes in Orange County, 2000-01.

concentrations in all four ranges plotted in figure 34 are located within urbanized areas of central Orange County. Most lakes in the northwest part of the County have relatively high total nitrogen concentrations, perhaps because of fertilizer usage in the agricultural areas.

The USEPA has recommended that total nitrogen concentrations in central Florida lakes and reservoirs should not exceed $0.52 \mathrm{mg} / \mathrm{L}$ (U.S. Environmental Protection Agency, 2000b). This criterion was exceeded in about one-half of the lakes sampled during this study (fig. 34). Presently, the FDEP is developing new nutrient criteria for lakes that will apply to specific regions within Florida, based on existing water-quality data. These new criteria probably will provide a better means for assessing water quality in lakes than the more general existing USEPA criteria.
Few pristine sites are present in Orange County, so assessing natural or background concentrations of nitrogen is difficult. Two ponds in Tosohatchee State Reserve had ammonia plus organic nitrogen concentrations ranging from 0.84 to $1.5 \mathrm{mg} / \mathrm{L}$ as nitrogen (appendix D). Concentrations of total nitrogen may exceed the USEPA recommendation even in pristine-appearing lakes.

Concentrations of total nitrogen exceeded $2.0 \mathrm{mg} / \mathrm{L}$ as nitrogen in samples from Lake Apopka, Lake Beauclair, Lake Carlton, Lake Cherokee, Lake Holden, John's Lake, Lake Kasey, Lake Kozart, Lake Lawsona, Lake Mann, Marshall Lake, and Lake Walker, and the Apopka-Beauclair Canal. Land use in many of these lake basins historically has been agricultural, but is changing to urban and residential. Hence, determining the source of nitrogen in these samples is difficult. 


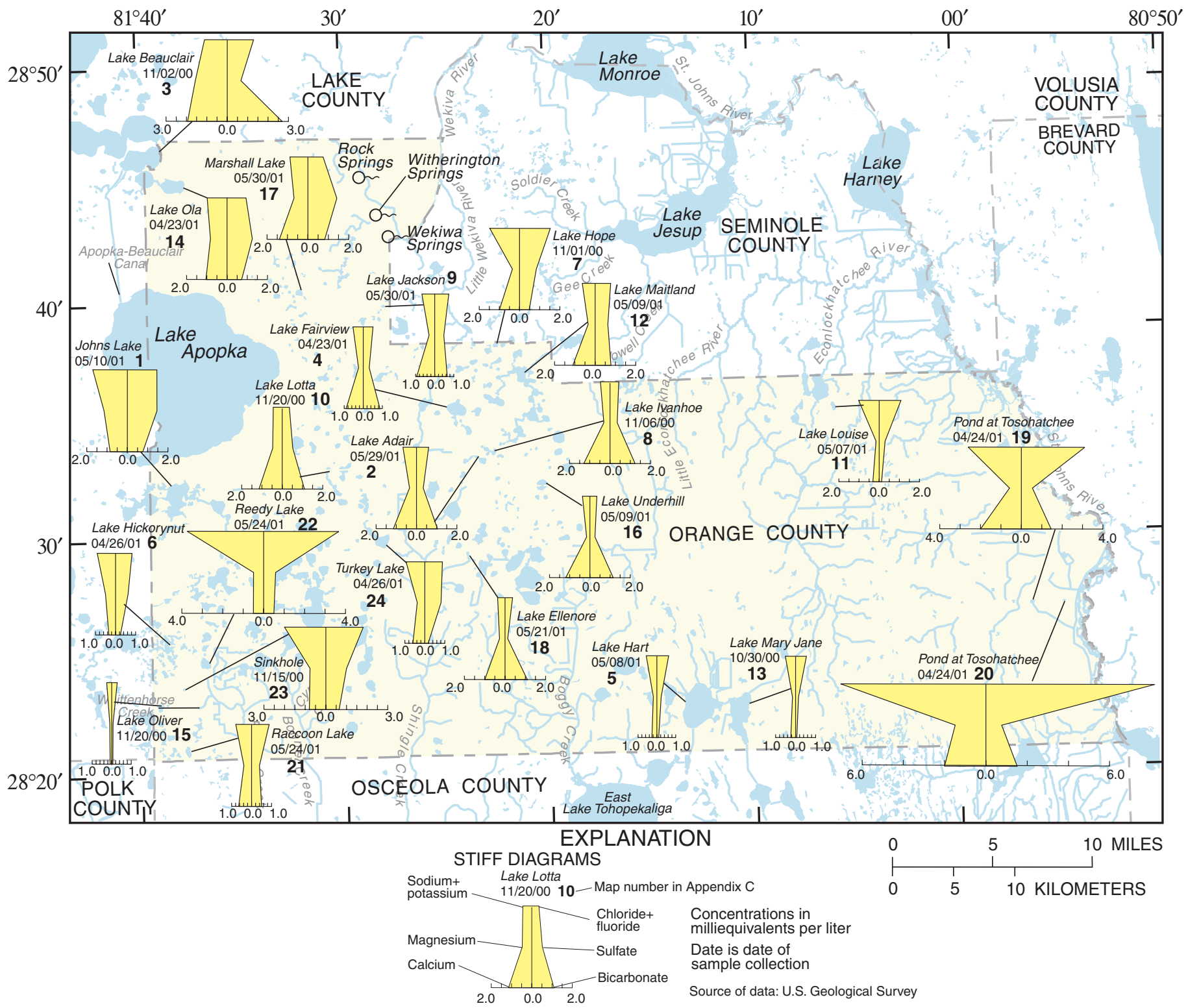

Figure 33. Concentrations of major cations and anions for selected lakes in Orange County, 2000-01. (Lake names and map numbers refer to appendix C.)

Concentrations of total phosphorus ranged from less than 0.02 to $0.38 \mathrm{mg} / \mathrm{L}$ as phosphorus. Most of the phosphorus present was as orthophosphate (table 17). The USEPA recommended criteria for phosphorus in central Florida lakes is $0.010 \mathrm{mg} / \mathrm{L}$ (U.S. Environmental Protection Agency, 2000b), which is lower than the detection limit for the samples taken during this study. About 25 percent of the samples had a phosphorus content of $0.04 \mathrm{mg} / \mathrm{L}$ or greater.

The source of phosphorus probably is not naturally occurring sediments. The Orlando Ridge lake region, in the central part of Orange County, is described as having phos- phatic sand and clay at shallow depths (Griffith and others, 1997). However, analysis of well logs in and around the Orlando Ridge region indicates that depth to the top of phosphatic sediments ranges from about 10 to $200 \mathrm{ft}$, with a median of about $50 \mathrm{ft}$. Many lakes with total phosphorus concentrations greater than the median of $0.02 \mathrm{mg} / \mathrm{L}$ (such as Lake Concord, Lake Eola, Lake Lawsona, Lake Mann, and Lake Rowena) are in areas where phosphatic sediments are 40 to $80 \mathrm{ft}$ below land surface, according to well logs. In addition, the altitude of the Upper Floridan aquifer potentiometric surface in the vicinity of Orlando ranges from about 40 to $50 \mathrm{ft}$ above NGVD 29 (Knowles, 2001). The surface 


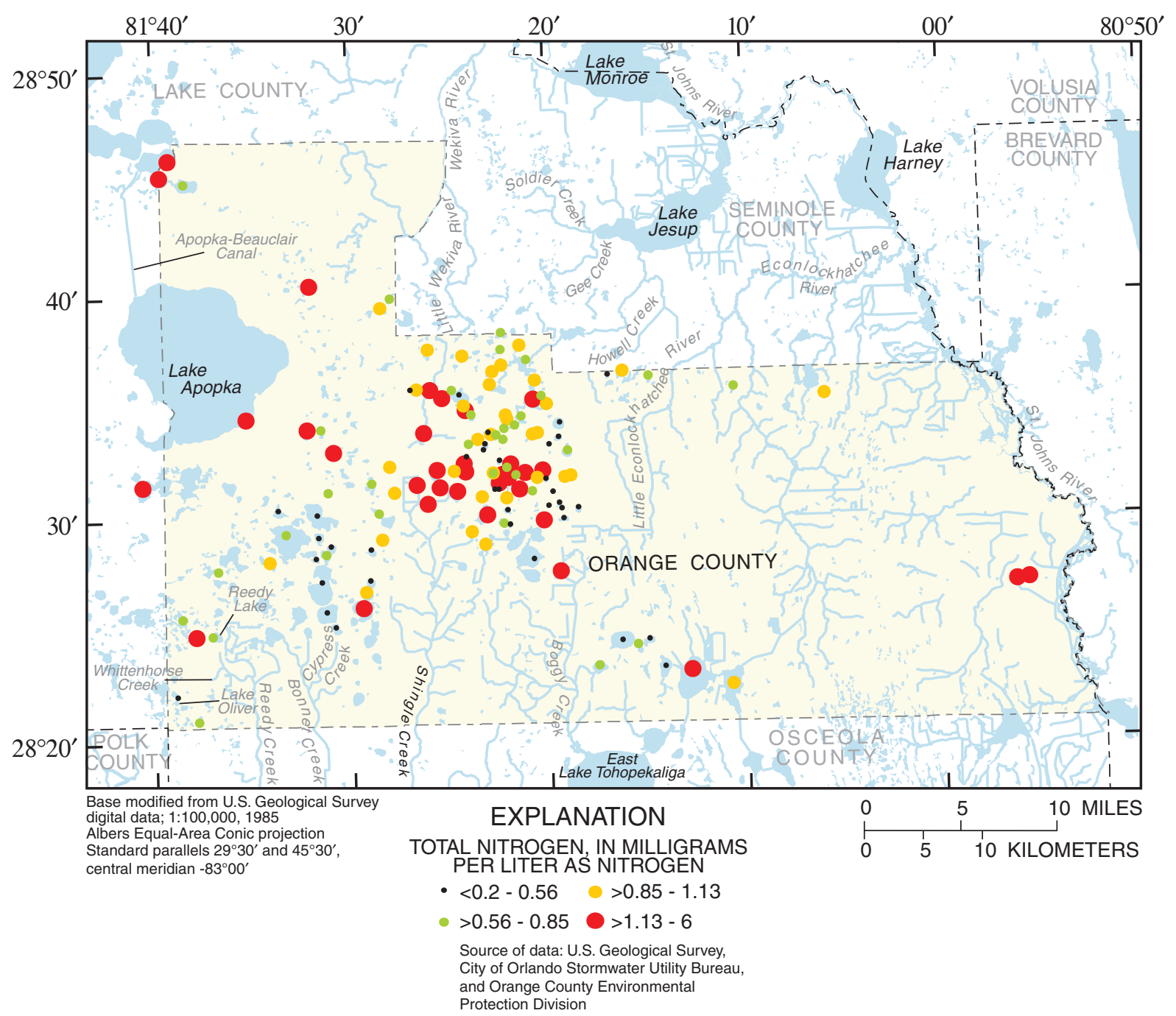

Figure 34. Total nitrogen concentrations for selected lakes in Orange County, 2000-01.

altitude of lakes in the area ranges from about 70 to $110 \mathrm{ft}$ above NGVD 29, indicating that the vertical flow of water generally would be downward.

Chlorophyll- $a$ ranged from less than 0.5 to $200 \mu \mathrm{g} / \mathrm{L}$ in samples from lakes (table 17; fig. 35). The USEPA recommended criterion for chlorophyll- $a$ in central Florida lakes is $2.6 \mu \mathrm{g} / \mathrm{L}$ (U.S. Environmental Protection Agency, $2000 \mathrm{~b})$. This criterion was exceeded in more than one-half of the lakes sampled in 2000-2001. Chlorophyll- $a$ concentrations exceeding $10 \mu \mathrm{g} / \mathrm{L}$ generally occurred in the urbanized central part of the County. However, not all lakes in central Orange County had water with chlorophyll- $a$ concentrations greater than $10 \mu \mathrm{g} / \mathrm{L}$

The TSI values for Orange County lakes ranged from 18 to 110 units (fig. 36). The highest TSI values (greater than 70) generally occurred in the urbanized central part of the County and in the northwest (agricultural) areas. However, not all lakes in the central part of the County had high TSI values-several had TSI values of 35 or less.

Lakes surrounded by relatively pristine land cover can have relatively high TSI values as a result of low water clarity, even if other water-quality constituents indicate a low trophic state. For example, Lake Hart and Lake Louise had relatively low concentrations of chlorophyll- $a$ (5.9 and $6.3 \mu \mathrm{g} / \mathrm{L}$, respectively; appendix C), but low water clarity of the lakes resulted in maximum TSI values of 54 and 55, respectively. Low water clarity, therefore, is not always related to high concentrations of chlorophyll- $a$, though the TSI values, which are a function of water clarity, would generally always be relatively high in colored lakes. This effect of water color may make interpretation of the TSI values difficult for lakes with high organic color. Brezonik 


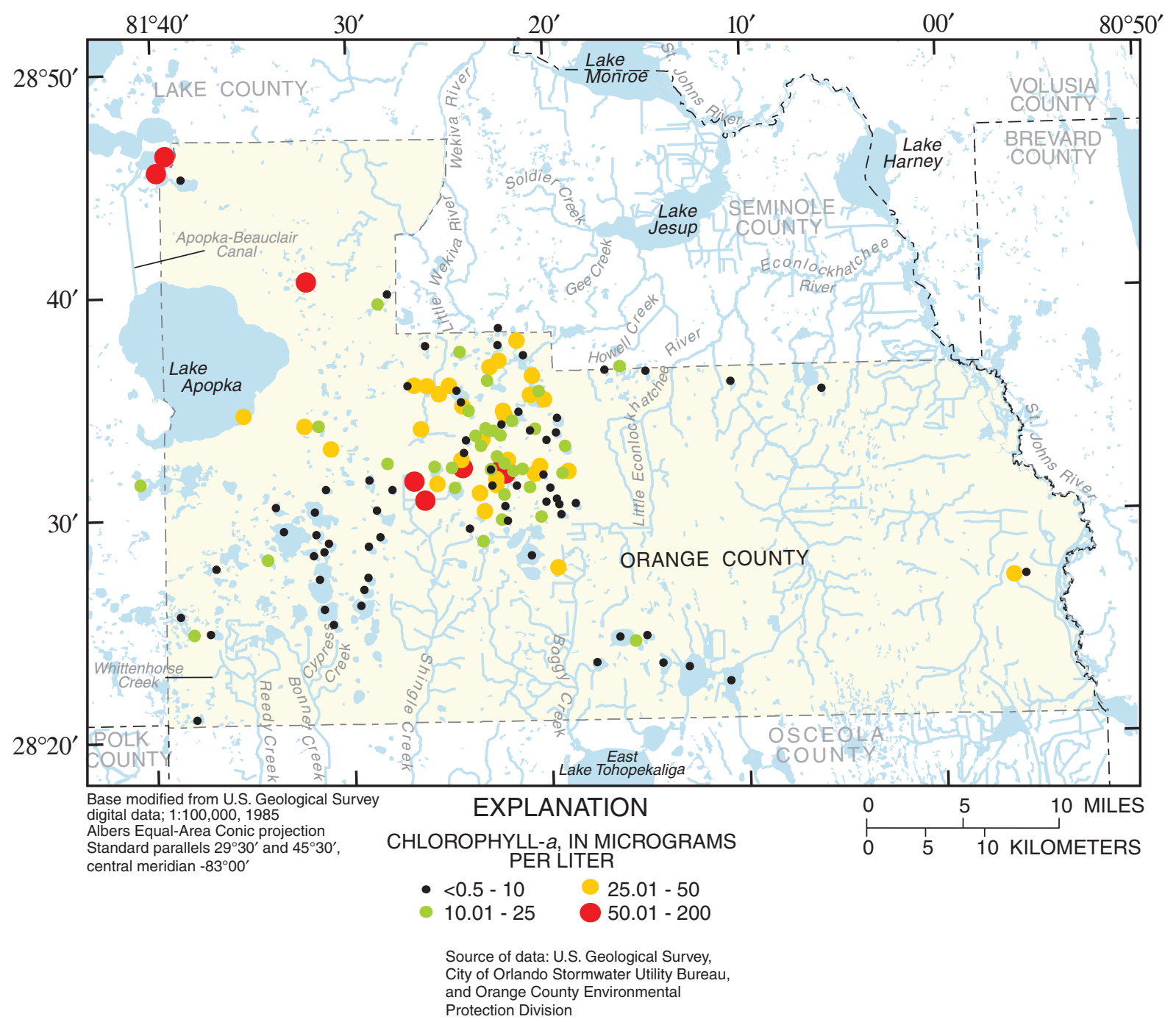

Figure 35. Chlorophyll-a concentrations for selected lakes in Orange County, 2000-01.

and Pollman (1999) reported that high levels of organic (humic) color apparently effect the way a lake responds to phosphorus enrichment, and recommended further studies to better define trophic response-nutrient loading relations in colored lakes.

Although chlorophyll- $a$ concentrations are related to phosphorus concentrations in lakes, the absence of phosphorus does not necessarily limit algal growth. Concentrations of chlorophyll- $a$ ranged from less than 0.5 to $139 \mu \mathrm{g} / \mathrm{L}$ in 240 samples from lakes with total phosphorus concentrations less than $0.02 \mathrm{mg} / \mathrm{L}$ (fig. 37).

The presence of relatively high concentrations of total phosphorus in samples from lakes, however, is almost always associated with high chlorophyll-a concentrations. Samples from 23 lakes with total phosphorus concentra- tions greater than or equal to $0.10 \mathrm{mg} / \mathrm{L}$ as phosphorus had relatively high chlorophyll- $a$ concentrations, ranging from 5.6 to $200 \mu \mathrm{g} / \mathrm{L}$, with a median of about $36 \mu \mathrm{g} / \mathrm{L}$, and relatively high TSI values, ranging from 53 to 110 , with a median of 80 . Hence, determining the source of phosphorus in lakes is important in understanding eutrophication.

Lakes with levels of chlorophyll- $a$ exceeding $10 \mu \mathrm{g} / \mathrm{L}$ generally have water clarity of less than $2 \mathrm{~m}$ (fig. 37). These lakes also are likely to have a green or brown turbid appearance because of the suspended algae that is the source of the chlorophyll- $a$. However, lakes with chlorophyll- $a$ concentrations less than $1 \mu \mathrm{g} / \mathrm{L}$ may have either low or high secchi-disk clarity, with clarity ranging from less than $1 \mathrm{~m}$ to more than $5 \mathrm{~m}$. The low clarity in 


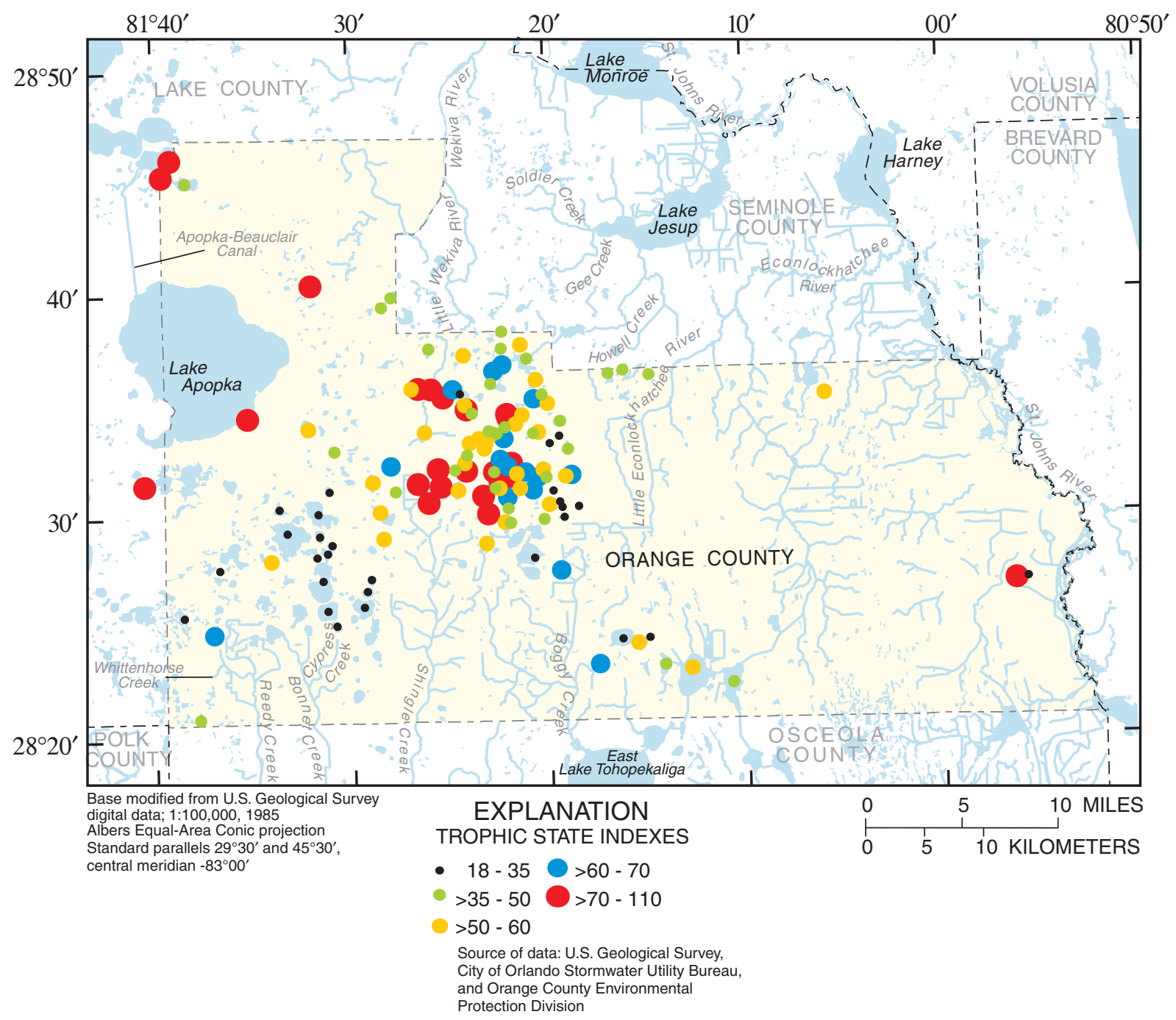

Figure 36. Trophic state indexes for selected lakes in Orange County, 2000-01.

lakes with low chlorophyll- $a$ concentrations is probably the result of humic compounds leached from leaves and other vegetative debris that are in contact with the water for extended time periods. The leached compounds give water a characteristic dark tea color, although the water itself generally contains little suspended material. Thus, lakes with low chlorophyll- $a$ concentrations may either contain clear, uncolored water with a high secchi disk reading, or clear (nonturbid) water with a high color and a low secchi-disk reading.

Water quality can vary significantly among lakes within a relatively small area. For example, samples from Lake Oliver (map no. 15 in figure 9) and nearby Reedy
Lake (map no. 22 in figure 9) in southwestern Orange County had the lowest and one of highest values of specific conductance (57 and $543 \mu \mathrm{S} / \mathrm{cm}$, respectively; appendix D). The sample from Lake Oliver also had a lower pH (5.1) than the sample from Reedy Lake (7.3, appendix D). Water from Raccoon Lake (map no. 21 in figure 9), also in southwest Orange County, had specific conductance of $206 \mu \mathrm{S} / \mathrm{cm}$ (appendix D). Water type of Lake Oliver and Reedy Lake is sodium chloride. Water type of Raccoon Lake is mixed cation and anion (fig. 33). Total nitrogen concentrations in samples from Lake Oliver, Raccoon Lake, and Reedy Lake were 0.47, 0.84, and $0.83 \mathrm{mg} / \mathrm{L}$ as nitrogen, respectively (appendix C). 

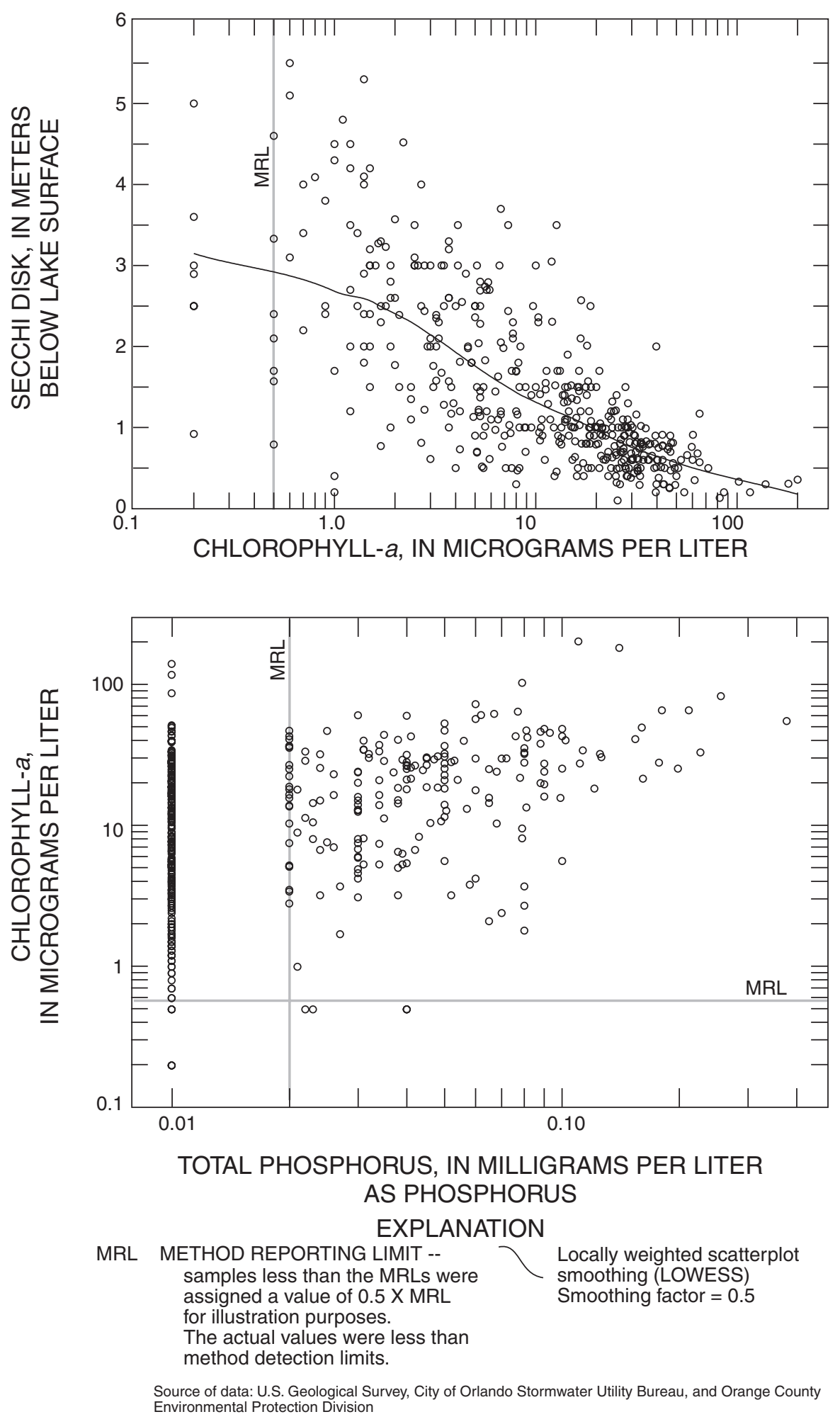

Figure 37. Relation of water clarity (secchi disk readings) with chlorophyll-a concentrations, and relation of chlorophyll-a concentrations to total phosphorus concentrations. 


\section{Hydrology and Water Quality of Lakes and Streams in Orange County, Florida}

The source of differences in water quality between Lake Oliver and Reedy Lake is difficult to determine. The shores of both lakes presently (2004) are surrounded by forests and wetlands; however, RIBs that receive treated wastewater (reclaimed water) are located upgradient (southwest) of Reedy Lake. Reclaimed water also is used to irrigate citrus groves south-southwest of Reedy Lake. The chemistry of water from Reedy Lake generally is within the chemical range of reclaimed water (table 18). In May 1991, measured specific conductance was $114 \mu \mathrm{S} / \mathrm{cm}$ and chloride concentration was $19 \mathrm{mg} / \mathrm{L}$ for Reedy Lake (Rebecca Gubert, Reedy Creek Improvement District, written commun., 2002). Although historical data for Reedy Lake are sparse, the water quality of Reedy Lake may have changed substantially in the past decade to reflect the influence of infiltrating RIB water.

Lake water quality in other parts of Orange County also ranges widely over short distances. In eastern Orange County, samples from two lakes (water-filled borrow pits remaining from road-construction activities) in Tosohatchee State Reserve had the highest specific conductance. Both lakes are located in the Eastern Flatlands region. Two samples from the first lake (map no. 19 in figure 9) had specific conductances of 450 and $558 \mu \mathrm{S} / \mathrm{cm}$. Specific conductance in the sample from the second lake (map no. 20 in figure 9), about $0.5 \mathrm{mi}$ east of the first lake, was $1,185 \mu \mathrm{S} / \mathrm{cm}$ (fig. 32 ; appendix D). The water type of the first and second lakes was calcium-sodium bicarbonate-chloride and sodium chloride, respectively (fig. 33). Water clarity also was substantially different between the two sites. Secchi disk readings for the first lake were 0.92 and $0.62 \mathrm{~m}$, and secchi disk reading for the second lake was more than $3.0 \mathrm{~m}$.

The water quality of the two lakes at Tosohatchee State Reserve probably is affected by ground-water discharge from the Upper Floridan aquifer. The potentiometric surface of the Upper Floridan aquifer is above land surface in eastern Orange County, indicating that the area is a place of potential ground-water discharge. The trace element strontium generally is present in relatively high concentrations in water from the Upper Floridan aquifer, compared with water from the surficial aquifer system (Adamski and German, 2003), and thus may be useful as an indicator of ground-water discharge. Specific conductance and strontium concentrations in samples from the lakes are similar to water from the Upper Floridan aquifer. Values of specific conductance from three nearby flowing wells that tap the Upper Floridan aquifer ranged from 2,790 to $4,190 \mu \mathrm{S} / \mathrm{cm}$. Strontium concentrations in samples from the three wells ranged from 4,200 to $6,500 \mu \mathrm{g} / \mathrm{L}$. Strontium concentrations in samples from the
Table 18. Comparison of water quality of Reedy Lake with range of water quality of reclaimed water.

[Reclaimed-water data from Sumner and Bradner (1996). Units are in milligrams per liter unless otherwise noted; $\mu \mathrm{S} / \mathrm{cm}$, microsiemens per centimeter]

\begin{tabular}{|lcc|}
\hline \multicolumn{1}{|c}{ Constituent } & $\begin{array}{c}\text { Reedy } \\
\text { Lake }\end{array}$ & $\begin{array}{c}\text { Reclaimed } \\
\text { water }\end{array}$ \\
\hline Specific conductance, $\mu \mathrm{S} / \mathrm{cm}$ & 543 & $480-550$ \\
$\mathrm{pH}$, standard units & 7.5 & $5.9-8.2$ \\
\hline Calcium & 10 & $25-35$ \\
Magnesium & 6 & $5.0-10$ \\
\hline Sodium & 79 & $45-80$ \\
Bicarbonate & 30 & $29-125$ \\
Chloride & 130 & $60-155$ \\
\hline
\end{tabular}

two lakes range from 450 to $1,600 \mu \mathrm{g} / \mathrm{L}$. In contrast, the median strontium concentration in 37 samples collected from lakes across Orange County is $57 \mu \mathrm{g} / \mathrm{L}$. Differences in water quality between the two lakes probably is related to the amount of discharge each lake receives from the Upper Floridan aquifer rather than to differences in land use, which is predominantly forested wetlands.

Water-quality data indicate that most large lakes in Orange County are well mixed. Field measurements were obtained at two to eight locations on selected large lakes (Fairview, Hart, Hickorynut, Louise, Maitland, Ola, Turkey, and Underhill). Results indicated that field measurements generally were consistent spatially and vertically in nearly all lakes. For example, at Lake Hart, a large lake in south-central Orange County, specific conductance at three locations and at depths of $0.15,0.9,1.5$, and $2.1 \mathrm{~m}$ on May 8, 2001, ranged from 114 to $115 \mu \mathrm{S} / \mathrm{cm} ; \mathrm{pH}$ ranged from 5.9 to 6.1 at the same locations; temperature ranged from about 23.1 to $23.6^{\circ} \mathrm{C}$.

In contrast, water quality in Lake Beauclair was vertically heterogeneous. Specific conductance at depths of 0.15 and $1.8 \mathrm{~m}$ was 441 and $514 \mu \mathrm{S} / \mathrm{cm}$, respectively. Temperature ranged from 25.4 and $22.9^{\circ} \mathrm{C}$, and concentrations of dissolved oxygen ranged from 16 to less than $0.1 \mathrm{mg} / \mathrm{L}$ at the same depths. Lake Beauclair had a secchi disk reading of $0.36 \mathrm{~m}$ and a chlorophyll- $a$ concentration of $200 \mu \mathrm{g} / \mathrm{L}$.

Seasonal variations in water quality are indicated by data from seven lakes, each of which had ten or more samples collected from June 2000 through October 2001 (fig. 38). However, the variations were not consistent among the lakes. For example, total phosphorus in samples from Lake Rowena ranged from less than 0.02 to 0.05 $\mathrm{mg} / \mathrm{L}$, whereas total phosphorus concentrations in samples from the other six lakes were all less than $0.02 \mathrm{mg} / \mathrm{L}$ 

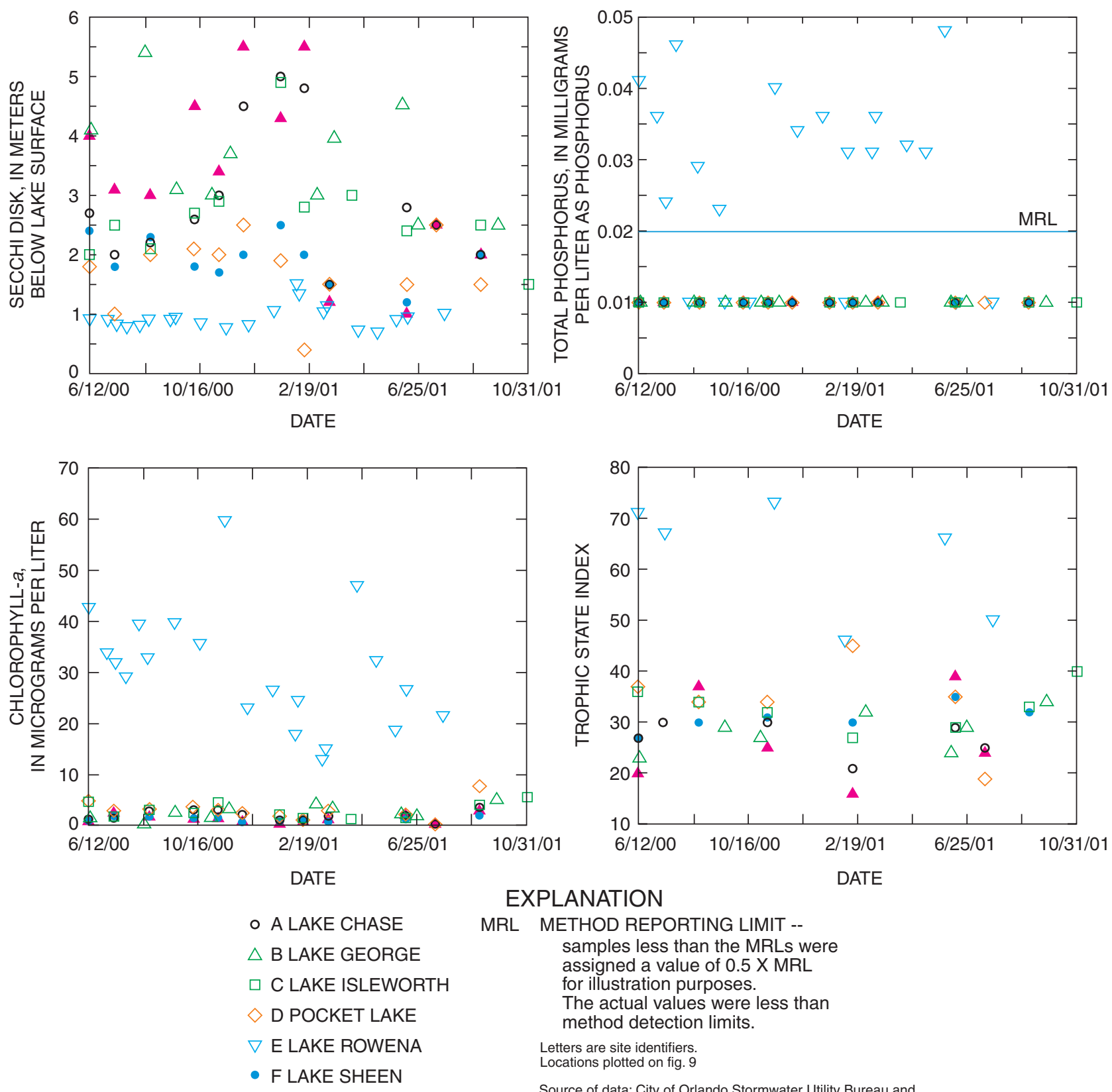

EXPLANATION

MRL METHOD REPORTING LIMIT -samples less than the MRLs were assigned a value of $0.5 \mathrm{XMRL}$ for illustration purposes.

The actual values were less than method detection limits.

Letters are site identifiers. Locations plotted on fig. 9

Source of data: City of Orlando Stormwater Utility Bureau and

- G LAKE TIBET-BUTLER Orange County Environmental Protection Division

Figure 38. Temporal variations of water clarity (secchi disk readings), total phosphorus and chlorophyll-a concentrations, and trophic state indexes for seven lakes in Orange County.

(fig. 38). Chlorophyll- $a$ concentrations in Lake Rowena ranged from 13 to $60 \mu \mathrm{g} / \mathrm{L}$, whereas chlorophyll- $a$ concentrations in samples from the other six lakes were all less than $10 \mu \mathrm{g} / \mathrm{L}$. Conversely, secchi disk readings in Lake Rowena consistently were $1.5 \mathrm{~m}$ or less, whereas secchi disk readings in six lakes increased during winter months. Lake Rowena also had the greatest TSI, ranging from 46 to 73. TSI values of the other six lakes all were less than 50 (fig. 38). Seasonal variations in these water-quality indicators probably are related to temperature, rainfall, and amount of sunlight, and subsequently, to algal and (or) cyanobacteria production. Lakes with low concentrations of nutrients and lower algal production, as indicated by chlorophyll- $a$ concentrations, have less variation in water quality throughout the year than does a lake with relatively higher concentrations of nutrients and chlorophyll- $a$. 


\section{Trace Elements in Streams and Lakes}

A total of 37 filtered samples from 24 lakes and 24 filtered samples from 11 streams was analyzed for 15 trace elements. In addition, 17 whole-water samples from 4 streams (Cypress, Bonnet Creek, Whittenhorse Creek, and Reedy Creek) were analyzed for 9 trace elements. The most commonly detected trace elements in lakes (table 19) and streams (table 20) were aluminum, barium, boron, iron, manganese, and strontium. Barium has a maximum contaminant level (MCL) in drinking water of $2,000 \mu \mathrm{g} / \mathrm{L}$ (U.S. Environmental Protection Agency, 2002). The maximum concentration of barium detected was $56 \mu \mathrm{g} / \mathrm{L}$ (table 19, appendix D), which was in a sample from one of the ponds at Tosohatchee State Reserve. Aluminum, iron, and manganese have secondary standards of 200,300, and $50 \mu \mathrm{g} / \mathrm{L}$, respectively (U.S. Environmental Protection Agency, 2002). The maximum concentrations of these constituents in samples from streams were: aluminum, $684 \mu \mathrm{g} / \mathrm{L}$ (Bonnet Creek); iron, 1,100 $\mu \mathrm{g} / \mathrm{L}$ (Bonnet Creek); and manganese, $550 \mu \mathrm{g} / \mathrm{L}$ (Jim Creek).
Arsenic was detected in 26 of 37 samples from lakes (table 19) and in 21 of 39 samples from streams (table 20). Selenium was detected in 8 of 37 samples from lakes and in 7 of 41 samples from streams. Arsenic and selenium both have an MCL of $50 \mu \mathrm{g} / \mathrm{L}$ for drinking water (U.S. Environmental Protection Agency, 2002). Maximum concentrations of arsenic and selenium were 7.2 and $3.0 \mu \mathrm{g} / \mathrm{L}$, respectively (table 20). Arsenic concentrations exceeded $4.0 \mu \mathrm{g} / \mathrm{L}$ in samples from the Apopka-Beauclair canal $(7.2 \mu \mathrm{g} / \mathrm{L})$, Lake Beauclair $(4.2 \mu \mathrm{g} / \mathrm{L})$, and Marshall Lake $(5.5 \mu \mathrm{g} / \mathrm{L})$ (U.S. Geological Survey, 2004a). The maximum selenium concentration $(3 \mu \mathrm{g} / \mathrm{L})$ was in a sample from the Little Wekiva River (U.S. Geological Survey, 2004a).

Four trace elements (beryllium, cadmium, chromium, and cobalt) were not detected in any samples. Lead was detected in only three whole-water samples from Cypress Creek and one whole-water sample from Reedy Creek. Lead has an MCL of $15 \mu \mathrm{g} / \mathrm{L}$ in drinking water (U.S. Environmental Protection Agency, 2002). The maximum lead concentration measured $(3.0 \mu \mathrm{g} / \mathrm{L})$ was in a sample from Cypress Creek (U.S. Geological Survey, 2004a).

Table 19. Summary statistics of trace-element concentrations in samples from 24 lakes in Orange County.

[All analyses on filtered samples; all units are in micrograms per liter]

\begin{tabular}{|lccccccc|}
\hline \multicolumn{1}{|c}{ Constituent } & $\begin{array}{c}\text { No. of } \\
\text { samples }\end{array}$ & $\begin{array}{c}\text { No. of } \\
\text { detections }\end{array}$ & Minimum & $\begin{array}{c}\text { 25th } \\
\text { percentile }\end{array}$ & Median & $\begin{array}{c}\text { 75th } \\
\text { percentile }\end{array}$ & Maximum \\
\hline Aluminum & 33 & 33 & 5.1 & 29 & 38 & 62 & 300 \\
Arsenic & 37 & 26 & .6 & .95 & 1.5 & 2.4 & 5.5 \\
Barium & 34 & 32 & .5 & 9 & 13 & 16 & 56 \\
\hline Beryllium & 34 & 0 & & & & & \\
Boron & 34 & 34 & 25 & 34 & 49 & 61 & 200 \\
Cadmium & 34 & 0 & & & & & \\
\hline Chromium & 34 & 0 & & & & & \\
Cobalt & 34 & 0 & & & & & \\
Iron & 37 & 31 & 1.2 & 3.4 & 9.2 & 67 & 835 \\
\hline Lead & 34 & 0 & & & & & \\
Lithium & 34 & 6 & .6 & 1 & 1.1 & 1.6 & 3 \\
Manganese & 37 & 24 & .3 & 1.3 & 3 & 5.9 & 15 \\
\hline Selenium & 37 & 8 & .5 & .5 & .75 & 1.6 & 1.6 \\
Strontium & 37 & 37 & 9 & 36 & 57 & 67 & 1,600 \\
Vanadium & 34 & 22 & 1 & 1 & 2 & 2 & 6 \\
\hline
\end{tabular}


Table 20. Summary statistics of trace-element concentrations in samples from 15 streams in Orange County.

[All analyses on filtered samples unless noted; all units are in micrograms per liter; --, not detected]

\begin{tabular}{|c|c|c|c|c|c|c|c|}
\hline Constituent & $\begin{array}{c}\text { No. } \\
\text { of } \\
\text { samples }\end{array}$ & $\begin{array}{c}\text { No. } \\
\text { of } \\
\text { detections }\end{array}$ & Minimum & $\begin{array}{c}\text { 25th } \\
\text { percentile }\end{array}$ & Median & $\begin{array}{c}\text { 75th } \\
\text { percentile }\end{array}$ & Maximum \\
\hline Aluminum, filtered & 21 & 21 & 13 & 22 & 44 & 60 & 170 \\
\hline Aluminum, whole water & 17 & 17 & 47 & 143 & 190 & 331 & 684 \\
\hline Arsenic, filtered & 24 & 8 & .3 & .65 & 1 & 2.2 & 7.2 \\
\hline Arsenic, whole water & 15 & 13 & 1 & 1.9 & 2.2 & 3.2 & 3.7 \\
\hline Barium & 24 & 24 & 9 & 12 & 14 & 17 & 35 \\
\hline Beryllium, filtered & 24 & 0 & -- & -- & -- & -- & -- \\
\hline Beryllium, whole water & 17 & 0 & -- & -- & -- & -- & -- \\
\hline Boron & 24 & 24 & 10 & 29 & 39 & 53 & 119 \\
\hline Cadmium, filtered & 22 & 0 & -- & -- & -- & -- & -- \\
\hline Cadmium, whole water & 17 & 0 & -- & -- & -- & -- & -- \\
\hline Chromium, filtered & 24 & 0 & -- & -- & -- & -- & -- \\
\hline Chromium, whole water & 17 & 0 & -- & -- & -- & -- & -- \\
\hline Cobalt & 24 & 0 & -- & -- & -- & -- & -- \\
\hline Iron, filtered & 24 & 23 & 3.3 & 52 & 128 & 210 & 516 \\
\hline Iron, whole water & 17 & 17 & 150 & 281 & 416 & 540 & 1,100 \\
\hline Lead, filtered & 24 & 0 & -- & -- & -- & -- & -- \\
\hline Lead, whole water & 17 & 4 & 1 & 1 & 1.5 & 2.3 & 3 \\
\hline Lithium & 24 & 17 & .8 & 1 & 1.1 & 1.4 & 3 \\
\hline Manganese, filtered & 24 & 23 & 1.1 & 5.5 & 9.4 & 11 & 550 \\
\hline Manganese, whole water & 17 & 17 & 4.8 & 8.9 & 9.9 & 15 & 63 \\
\hline Selenium, filtered & 24 & 6 & .5 & 1.2 & 2.4 & 2.9 & 3 \\
\hline Selenium, whole water & 17 & 1 & 1.4 & -- & -- & -- & -- \\
\hline Strontium & 24 & 24 & 22 & 77 & 140 & 175 & 410 \\
\hline Vanadium & 24 & 13 & 1 & 2 & 2 & 2 & 6 \\
\hline
\end{tabular}

\section{Pesticides in Streams and Lakes}

Pesticides are synthetic, organic compounds used to control insects (insecticides), plants (herbicides), fungi (fungicides), and other nuisance organisms. For pesticide analysis, 18 samples from 6 stream sites (table 21) and 26 samples from 13 lakes (table 22) were collected (appendix E). The results indicate that low concentrations of pesticides are ubiquitous and persistent in the surface-water resources of Orange County. Pesticides were detected in nearly every sample and at every site (appendix E).

Pesticides were detected in nearly all samples from the six stream sites during all three sampling periods. The maximum number of pesticide compounds detected in a single sample was nine (Little Econlackhatchee River, table 21). The only sample with no detectable concentrations of pesticides was the sample collected from the Wekiva River near Apopka in February 2001 (table 21). Similarly, pesticides were detected in nearly all samples from all 13 lakes during all 3 sampling periods. The maximum number of pesticide compounds detected in a single sample was six. The only sample with no detectable concentrations of pesticides was a sample collected from Lake Hart in July 2000 (table 22).

The most commonly detected compounds were herbicides, including atrazine, prometon, simazine (triazine herbicides for control of broad leaf plants), and tebuthiuron (a nonselective herbicide). The most commonly detected insecticide was diazinon (table 23). Concentrations generally were low, with many results reported as measured but not quantified. The maximum concentration of any pesticide was $0.7 \mu \mathrm{g} / \mathrm{L}$ for atrazine. Atrazine and simazine have MCLs set for drinking water of 3.0 and $4.0 \mu \mathrm{g} / \mathrm{L}$, respectively (U.S. Environmental Protection Agency, 2002).

In general, the number of compounds and concentrations detected were similar among the periodic samples collected from each site. For example, samples collected 
Table 21. Stream sites, date of sample collection, and number of pesticide compounds detected in each sample.

\begin{tabular}{|lrrr|}
\hline \multicolumn{1}{|c}{ Station name } & $\begin{array}{c}\text { Station } \\
\text { identifier }\end{array}$ & Date & $\begin{array}{c}\text { No. } \\
\text { of } \\
\text { detections }\end{array}$ \\
\hline Boggy Creek & 02262900 & $4 / 26 / 2000$ & 4 \\
& & $9 / 6 / 2000$ & 4 \\
& & $2 / 22 / 2001$ & 3 \\
\hline Econlockhatchee River & 02233500 & $4 / 12 / 2000$ & 7 \\
& & $9 / 5 / 2000$ & 6 \\
& & $2 / 6 / 2001$ & 3 \\
\hline Littlle Econlockhatchee River Wekiva River & 02233200 & $4 / 25 / 2000$ & 5 \\
& & $8 / 31 / 2000$ & 9 \\
& & $2 / 8 / 2001$ & 6 \\
\hline Shingle Creek & 02234990 & $4 / 11 / 2000$ & 8 \\
& & $8 / 29 / 2000$ & 6 \\
& & $2 / 14 / 2001$ & 7 \\
\hline Wekiva River & 02263800 & $4 / 24 / 2000$ & 6 \\
& & $9 / 13 / 2000$ & 4 \\
& & $2 / 28 / 2001$ & 3 \\
\hline & 02234635 & $4 / 12 / 2000$ & 4 \\
& & $9 / 6 / 2000$ & 5 \\
& & $2 / 5 / 2001$ & 0 \\
\hline
\end{tabular}

from Lake Fairview in July 2000, November 2000, and April 2001 each had four pesticides detected (atrazine, diazinon, prometon, and tebuthiuron) at concentrations ranging from about 0.005 to $0.155 \mu \mathrm{g} / \mathrm{L}$ (appendix $\mathrm{E}$ ). The number of detections was slightly more variable for periodic samples from streams. The number of detections from the Wekiva River ranged from none (February 2001) to five (September 2000), and the number of detections in the Little Econlockhatchee River ranged from five (April 2000) to nine (August 2000; table 21).

Multiple sources probably contribute to the occurrence of pesticides in surface water. Pesticides were detected in 10 of 34 ground-water samples (16 surficial aquifer system wells, 14 Upper Floridan aquifer wells, and 4 Lower Floridan aquifer wells) collected from April 1999 through February 2000 (Adamski and German, 2003). The surfacewater samples collected for this study were collected during baseflow conditions when ground water contributes most of the flow to streams. However, the number and concentrations of pesticides detected in ground-water samples were less than in surface-water samples. Ten pesticides were detected in all the ground-water samples, with a maximum number of compounds detected in any one sample being three. The maximum concentration detected was $0.42 \mu \mathrm{g} / \mathrm{L}$ for simazine (Adamski and German, 2003). Hence, ground water probably is not the only source of pesticides to lakes and streams.
Because the surface-water samples were collected during baseflow, runoff probably did not contribute to pesticide concentrations in streams. However, runoff to lakes during wet periods could have contributed pesticides, which may persist during dry conditions.

Pesticide detections in samples from relatively pristine sites, such as the pond at Tosohatchee State Reserve (table 22), indicate that airborne sources could contribute some pesticides to surface-water resources. Pesticides have been detected in both rain and dry-deposition samples across the United States (Majewski and Capel, 1995). However, the number of pesticides detected and the concentrations (atrazine at 0.007 and $0.003 \mu \mathrm{g} / \mathrm{L}$; appendix E) in the two samples from the pond at Tosohatchee were much less than at other sites with nearby agricultural or urban land use such as Lake Ola or Turkey Lake (table 22).

Table 22. Lake site, date of sample collection, and number of pesticide compounds detected in each sample.

\begin{tabular}{|c|c|c|c|}
\hline Station name & Station identifier & Date & $\begin{array}{c}\text { No. } \\
\text { of } \\
\text { detections }\end{array}$ \\
\hline Lake Adair & 02234205 & $5 / 29 / 2001$ & 6 \\
\hline Lake Ellenore & 282927081235000 & $5 / 21 / 2001$ & 6 \\
\hline \multirow[t]{3}{*}{ Lake Fairview } & 02234812 & $7 / 12 / 2000$ & 5 \\
\hline & & $11 / 6 / 2000$ & 5 \\
\hline & & $4 / 23 / 2001$ & 5 \\
\hline \multirow[t]{3}{*}{ Lake Hart } & 02262200 & $7 / 20 / 2000$ & 0 \\
\hline & & $10 / 30 / 2000$ & 3 \\
\hline & & $5 / 8 / 2001$ & 4 \\
\hline \multirow[t]{2}{*}{ Lake Hickorynut } & 02266275 & $7 / 18 / 2000$ & 2 \\
\hline & & $4 / 26 / 2001$ & 5 \\
\hline \multirow[t]{2}{*}{ Lake Hope } & 02234297 & $7 / 19 / 2000$ & 4 \\
\hline & & $11 / 1 / 2000$ & 5 \\
\hline Lake Jackson & 284000081275000 & $5 / 30 / 2001$ & 2 \\
\hline \multirow[t]{3}{*}{ Lake Louise } & 283528081055300 & $7 / 19 / 2000$ & 3 \\
\hline & & $11 / 1 / 2000$ & 4 \\
\hline & & $5 / 7 / 2001$ & 1 \\
\hline \multirow[t]{3}{*}{ Lake Ola } & 02237745 & $7 / 18 / 2000$ & 6 \\
\hline & & $11 / 2 / 2000$ & 4 \\
\hline & & $4 / 23 / 2001$ & 4 \\
\hline Lake Marshall & 284034081315700 & $5 / 30 / 2001$ & 3 \\
\hline \multirow{2}{*}{$\begin{array}{l}\text { Pond at } \\
\text { Tosohatchee }\end{array}$} & 282657080561900 & $11 / 8 / 2000$ & 1 \\
\hline & & $4 / 24 / 2001$ & 2 \\
\hline Raccoon Lake & 282102081374600 & $5 / 24 / 2001$ & 6 \\
\hline \multirow[t]{3}{*}{ Turkey Lake } & 283019081283100 & $7 / 13 / 2000$ & 5 \\
\hline & & $10 / 31 / 2000$ & 4 \\
\hline & & $4 / 26 / 2001$ & 6 \\
\hline
\end{tabular}


Table 23. Pesticide compounds, number of detections, and range of concentrations in samples from lakes and streams in Orange County, 2000-01.

[All units are in micrograms per liter; E, estimated concentrations]

\begin{tabular}{|c|c|c|c|c|c|c|}
\hline \multirow{2}{*}{$\begin{array}{l}\text { Pesticide } \\
\text { compound }\end{array}$} & \multicolumn{2}{|c|}{$\begin{array}{l}\text { Lake samples } \\
\text { (26 samples) }\end{array}$} & \multicolumn{2}{|c|}{$\begin{array}{c}\text { Stream samples } \\
\text { (18 samples) }\end{array}$} & \multirow{2}{*}{$\begin{array}{c}\text { Total } \\
\text { No. of } \\
\text { detections }\end{array}$} & \multirow{2}{*}{$\begin{array}{c}\text { Total } \\
\text { range of } \\
\text { concentrations }\end{array}$} \\
\hline & $\begin{array}{c}\text { No. of } \\
\text { detections }\end{array}$ & $\begin{array}{c}\text { Range of } \\
\text { concentrations }\end{array}$ & $\begin{array}{c}\text { No. of } \\
\text { detections }\end{array}$ & $\begin{array}{c}\text { Range of } \\
\text { concentrations }\end{array}$ & & \\
\hline Atrazine & 25 & E0.003 - 0.375 & 17 & E0.002 - 0.716 & 42 & E0.002- 0.716 \\
\hline Carbaryl & 3 & E.004 - E.023 & 6 & E.004 - E.022 & 9 & E.004 - E.023 \\
\hline Chlorpyrifos & 1 & E.003 & 2 & E.002 - .005 & 3 & E.002 - .005 \\
\hline Deethyl Atrazine & 16 & E.002 - E.038 & 15 & E.006 - .078 & 31 & E.002 - E.078 \\
\hline Diazinon & 14 & E.003 - .026 & 10 & E.004 - .087 & 24 & E.002 - .087 \\
\hline Malathion & 0 & & 1 & .025 & 1 & .025 \\
\hline Metolachlor & 8 & E.001 - E.004 & 2 & E.002 - .009 & 10 & E.001 - .009 \\
\hline Pendimethalin & 1 & E.008 & 1 & .004 & 2 & .004 - E.008 \\
\hline Prometon & 17 & E.003 - .04 & 16 & E.003 - E.012 & 33 & E.003 - .04 \\
\hline Simazine & 8 & E.002 - .016 & 8 & E.004 - .009 & 16 & E.003 - .016 \\
\hline Tebuthiuron & 7 & E.005 - E.02 & 10 & E.004 - .02 & 17 & E.004 - .02 \\
\hline Trifluralin & 0 & & 1 & E.003 & 1 & E.003 \\
\hline
\end{tabular}

These results indicate that no single source or process contributes to the occurrence and distribution of pesticides in surface-water resources of Orange County. Although atmospheric deposition is important, local land use and ground-water discharge also contribute pesticides to surface water. Additional study is needed to better quantify the contribution of each source. Furthermore, these data were collected under baseflow conditions. Data-collection under different hydrologic conditions, such as flooding, is needed to understand the effects of discharge and overland runoff on concentrations and loads at the sites.

\section{Household and Industrial Waste Compounds in Streams and Lakes}

Samples from four lakes (Adair, Ellenore, Fairview, and Hope) and four streams (Econlockhatchee River, Little Econlockhatchee River, Little Wekiva River, and Shingle Creek) were collected for analysis of compounds indicative of household and industrial wastes using a method described by Zaugg and others (2002). A duplicate sample also was collected from Lake Hope for quality assurance purposes. These sites were selected because their basins have a large percentage of urban and residential land use.

Results indicate that many of the compounds were detected at low concentrations in every sample. The number of compounds per sample ranged from 3 compounds in the samples from Lake Ellenore to 12 compounds in the sample from the Little Econlockhatchee River. Concentrations of most compounds were less than $1 \mu \mathrm{g} / \mathrm{L}$. The maximum concentrations (estimated) of detected compounds were $1.4 \mu \mathrm{g} / \mathrm{L}$ for para-nonylphenol in the sample from Little Econlockhatchee River, and $1.4 \mu \mathrm{g} / \mathrm{L}$ of NPEO1total in a sample from Lake Hope (table 24). In general, the concentrations and the number of compounds detected in the two samples from Lake Hope were in good agreement (table 24), indicating good reproducibility of results. In addition, concentrations of diazinon detected with this method in samples from Lake Adair, Lake Hope, Little Econlockhatchee River, and the Little Wekiva River were in good agreement with the results of the pesticide analyses discussed in the previous section. For example, diazinon concentrations in the samples from Lake Adair were 0.04 and $0.03 \mu \mathrm{g} / \mathrm{L}$ for the household waste method and the pesticide analysis, respectively.

The source of many of these compounds is wastewater or septic-tank effluent. For example, 3beta-coprostanol (table 24) is a carnivore fecal indicator, generally indicating human waste. Caffeine is consumed in coffee, tea, and other popular beverages and may be introduced into wastewater systems. The mosquito repellent $\mathrm{N}, \mathrm{N}$-diethyl-metatoluamide (DEET) may also be introduced into wastewater systems through bathing or laundry wastewater, or may enter water bodies directly through recreational activities such as fishing and swimming. Other compounds, such as pyrene, are additives in asphalt and could result from runoff of paved surfaces (Zaugg and others, 2002). 
Table 24. Selected results of analysis of surface-water samples for household and industrial wastes compounds.

[All units are in micrograms per liter; E, estimated concentrations; NA, not analyzed; <, less than]

\begin{tabular}{|c|c|c|c|c|c|}
\hline Constituent & Use or source ${ }^{a}$ & $\begin{array}{c}\text { Little } \\
\text { Econlockhatchee } \\
\text { River }\end{array}$ & $\begin{array}{c}\text { Econlockhatchee } \\
\text { River }\end{array}$ & Lake Hope & $\begin{array}{l}\text { Lake Hope } \\
\text { (duplicate) }\end{array}$ \\
\hline 3beta-coprostanol & carnivore fecal indicator & $<0.600$ & E.542 & $<0.600$ & $<0.600$ \\
\hline 5-Methyl-1H-benzotriazle & antioxidant in antifreeze & $<.100$ & E. 138 & $<.100$ & $<.100$ \\
\hline Caffeine & beverages; plants & E.074 & E.068 & $<.080$ & $<.080$ \\
\hline Cotinine & nicotine metabolite & .051 & $<.080$ & $<.040$ & $<.040$ \\
\hline Diazinon & insecticide & .139 & $<.030$ & $<.030$ & E.023 \\
\hline Fluoranthene & component of asphalt & E.024 & $<.030$ & E.011 & E.007 \\
\hline N,N-diethyl-meta-toluamide (DEET) & mosquito repellent & E.089 & E.078 & E.023 & E.029 \\
\hline NPEO1-total & detergent metabolite & $<1.00$ & E1.140 & E1.400 & E1.370 \\
\hline OPEO1 & detergent metabolite & E.074 & E.140 & E.070 & E.056 \\
\hline para-Cresol & wood preservative & E.046 & $<.060$ & $<.040$ & $<.040$ \\
\hline para-nonylphenol, total & detergent metabolite & E1.4 & E.528 & E.390 & $<.500$ \\
\hline Pyrene & component of asphalt & E.018 & $<.030$ & E.011 & E.006 \\
\hline Tri(2-chloroethyl)phosphate & plasticizer; flame retardant & .117 & .075 & .04 & E.037 \\
\hline Triclosan & disinfectant & NA & E.034 & NA & NA \\
\hline
\end{tabular}

aZaugg and others (2002).

A few of the compounds detected in these samples have known or suspected environmental effects. For example, the nonylphenol compounds (NPEO1, OPEO1, and para-nonylphenol) are detergent metabolites with endocrine-disrupting potential (Zaugg and others, 2002). Triclosan, an antimicrobial ingredient in household soaps and cleaners, could cause the growth of resistant strains of bacteria (Zaugg and others, 2002). Hence, more study is needed to assess the occurrence and distribution of these compounds in lakes and streams.

\section{Summary and Conclusions}

The increase of population, tourism, and industry in Orange County, Florida, and nearby areas has changed land use. These changes could impact surface-water resources that are important for wildlife habitat, for esthetic reasons, and potentially for potable supply. Streamflow characteristics and water quality could be affected in various ways. Rainfall data for 1930-2000 and streamflow data from 1934-2000 were compiled and analyzed to determine if changes in streamflow occurred. Water-quality data from lakes and streams for 1960-2000 were analyzed. During 2000-01, additional samples were collected.
Selected streamflow characteristics computed on an annual basis for 13 stations were examined statistically for temporal trends using the Kendall Tau test. Results of the trend testing indicate changes in annual mean streamflow, 1-day high streamflow, or 7-day low streamflow at 9 of the 13 stations. However, changes in 7-day low streamflow are more common than changes in annual mean or 1-day high streamflow.

Statistical tests and graphical analyses indicate temporal changes in 7-day low streamflow at 7 of the 13 streamflow stations: Little Econlockhatchee River, Econlockhatchee River near Chuluota, Little Wekiva River, Wekiva River, Boggy Creek, Whittenhorse Creek, and Reedy Creek. Streamflow increased with time in all of these streams except the Little Wekiva River. Low flow in Shingle Creek increased from 1972 until 1984 in response to treated wastewater discharge and decreased after 1984 when the treated wastewater was redirected from Shingle Creek to other means of disposal. However, 7-day low flows in Shingle Creek generally have been greater after 1989 than before 1984 .

There is probably no single reason for the increases in 7-day low streamflows, and for most streams it is difficult to determine definite reasons for the flow increases. Lowflows in the Econlockhatchee River at Chuluota increased because of discharge of treated wastewater. Reasons for the apparent increases in 7-day low flows in Little 
Econlockhatchee River, Boggy Creek, Reedy Creek since 1990, Shingle Creek since 1989, and the nonwastewater component of the 7-day low flow in the Econlockhatchee River may be related to drainage changes related to the increased development in Orange County. These changes in land drainage can lower the water table, resulting in reductions of regional evapotranspiration rates and increased streamflow. Another possible cause of increasing low flows in streams is use of water from the Floridan aquifer system for irrigation. Runoff of irrigation water, or increased seepage from irrigated areas to streams, could increase base streamflow compared to natural conditions.

Double-mass plots indicate that streamflow-rainfall relations may have changed with time for Little Econlockhatchee River, Wekiva River, Apopka-Beauclair Canal, Boggy Creek, Shingle Creek, Whittenhorse Creek, and Reedy Creek. Streamflow increased for a selected rainfall amount at all stations except Apopka-Beauclair Canal. The double-mass analysis supports the Kendall Tau test and plots of annual mean streamflow, indicating that annual mean streamflow has increased in Little Ecohlockhachee River, Boggy Creek, Shingle Creek, Whittenhorse Creek, and Reedy Creek. However, for the Apopka-Beauclair Canal, the double-mass plots indicate a decrease in annual mean streamflow relative to rainfall beginning about 1977.

Water levels in 83 lakes that had more than 15 years of water-level record were examined statistically and graphically for trends. Using the entire period of record for each lake, there were significant temporal trends in 33 (40 percent) of the 83 lakes. Of these 33 lakes, 14 had increasing water levels and 19 lakes had decreasing water levels. The reason for the predominance of downwards trends in longterm record may be the extreme high-water conditions that existed for many lakes in 1960 and following years as the result of 2 years of relatively high rainfall culminated by rains from Hurricane Donna in September 1960. Historical high-water levels occurred in many lakes in 1960 or 1961. In many lakes, there is little likelihood that the highwater levels of 1959-60 will be repeated, because drainage wells were constructed to provide lake drainage or intercept storm runoff. For many or even most lakes, there has not been a uniform pattern of declining or increasing water level over the period of record. Instead, periods of declining water levels and periods of increasing water levels have occurred. This pattern of lake-level fluctuations is similar to patterns in rainfall.

Data indicate that a large range of water-quality conditions exists in lakes and streams of Orange County (2000-01). Specific conductance in samples from lakes ranged from 57 to 1,185 microsiemens per centimeter $(\mu \mathrm{S} / \mathrm{cm})$, with a median of $202 \mu \mathrm{S} / \mathrm{cm}$. Values of $\mathrm{pH}$ ranged from 3.2 to 8.7 in samples from streams and 4.6 to 9.6 in samples from lakes. Specific conductance in samples from streams draining Orange County ranged from 84 to 617 $\mu \mathrm{S} / \mathrm{cm}$, with a median of $269 \mu \mathrm{S} / \mathrm{cm}$.

A total of 37 filtered samples from 24 lakes and 24 filtered samples from 11 streams was analyzed for 15 trace elements. In addition, 17 whole-water samples from Cypress Creek, Bonnet Creek, Whittenhorse Creek, and Reedy Creek were analyzed for 9 trace elements. The most commonly detected trace elements were aluminum, barium, boron, iron, manganese, and strontium.

Data for 1960-2001 from four sites (Boggy Creek, Bonnet Creek, Econlockhatchee River, and Whittenhorse Creek) were analyzed for trends in specific conductance, bicarbonate, sulfate, chloride, nitrite plus nitrate nitrogen, ammonia plus organic nitrogen, and phosphorus. All four sites had significant trends in at least two of the seven constituents. Values of specific conductance and concentrations of chloride increased at the Boggy Creek, Bonnet Creek, and Whittenhorse Creek sites. Bicarbonate concentrations increased at the Econlockhatchee River, Boggy Creek, and Bonnet Creek sites. Sulfate concentrations increased at the Boggy Creek site. Concentrations of nitrite plus nitrate and ammonia plus organic nitrogen decreased at the Econlockhatchee River site. Phosphorus concentrations significantly decreased at the Econlockhatchee River and Boggy Creek sites. Many of these changes probably are related to changes in land use. However, the Econlockhatchee River near Chuluota has been affected by wastewater discharges.

A total of 18 samples from 6 stream sites and 26 samples from 13 lakes was collected for pesticide analysis. The results indicate that low concentrations of pesticides are ubiquitous and persistent in the surface-water resources of Orange County. Pesticides were detected in nearly every sample.

The most commonly detected compounds were herbicides, including atrazine, prometon, simazine (triazine herbicides for control of broadleaf plants), and tebuthiuron (a nonselective herbicide). The most commonly detected insecticide was diazinon. Concentrations generally were low, with many results reported as estimated values. The highest concentration was 0.716 microgram per liter $(\mu \mathrm{g} / \mathrm{L})$ for atrazine. In general, the number of compounds and concentrations detected were similar among the periodic samples collected from each site.

Samples from four lakes and four streams in Orange County were collected and analyzed for compounds indicative of household and industrial wastes. The number of compounds detected in each samples ranged from 3 to 12 . 
Concentrations were less than $1 \mu \mathrm{g} / \mathrm{L}$ for most compounds. The source of many of the compounds is related to wastewater or urban runoff. Several of the compounds have known or suspected environmental effects. Nonylphenol compounds, which are detergent metabolites, are known to have endocrine disrupting potential. Triclosan, an antimicrobial ingredient in many household soaps and detergents, could cause the growth of resistant strains of bacteria. Further study is needed to assess the occurrence and distribution of these compounds in lakes and streams of central Florida.

\section{References}

Adamski, J.C., and German, E.R., 2003, Hydrogeology and quality of ground water in Orange County, Florida: U.S. Geological Survey Water-Resources Investigations Report 03-4257, $113 \mathrm{p}$.

Adamski, J.C., and Knowles, Leel, Jr., 2001, Ground-water quality of the surficial aquifer system and the Upper Floridan aquifer, Ocala National Forest and Lake County, Florida, 1990-99: U.S. Geological Survey Water-Resources Investigations Report 01-4008, 51 p.

Anderson, J.R., Hardy, E.H., Roach, J.T., and Witmer, R.E., 1976, A land use and land cover classification system for use with remote sensor data: U.S. Geological Survey Professional Paper 964, $281 \mathrm{p}$.

Anderson, Warren, and Joyner, B.F., 1966, Availability and quality of surface water in Orange County, Florida: Tallahassee, Florida Geological Survey Map Series 24, 1 sheet.

Brezonik, P.L., 1984, Trophic state indices: Rational for multivariate approaches, in Lake and Reservoir Management, October 18-23, Knoxville Tennessee, EPA 440/5-84-001 U.S. Environmental Protection Agency, Washington, D.C., p. 441-445.

Brezonik, P.L., Hendry, C.D., and Edgerton, E.S., 1980, Acid rainfall and sulfate deposition in Florida: Science, v. 208, no. 4447, p. 1027-1029.

Brezonik, P.L., and Pollman, C.D., 1999, Phosphorus chemistry and cycling in Florida lakes: Global issues and local perspectives, in Reddy, K.R., O'Connor, G.A., and Schelske, C.L., eds., Phosphorus biogeochemistry in subtropical ecosystems: New York, Lewis Publishers, p. 69-110.

CDM, 2003, Little Wekiva River watershed management plan-Part 1inventory update: Prepared for the St. Johns River Water Management District, Altamonte Springs, Florida.

City of Orlando, 2004, City of Orlando.net [accessed July 9, 2004] http://www.cityoforlando.net/public_works/ stormwater/Index.htm.

Cleveland, W.S., 1979, Robust locally weighted regression and smoothing scatterplots: Journal of the American Statistical Association, v. 74, no. 368, p. 829-836.
Conover, W.J., 1980, Practical nonparametric statistics (2d ed.): New York, John Wiley and Sons, 493 p.

Florida Department of Environmental Protection, 2002, Total daily maximum loads--303(d) maps by county [accessed March 8, 2002] http://www.dep.state.fl.us/water/tmdl/ 303dmap.htm.

Gaggiani, N.G., and Lamonds, A.G., 1977, Chemical and biological quality of Lakes Faith, Hope, and Charity, at Maitland, Florida, with emphasis on the effects of storm runoff and bulk precipitation, 1971-74: U.S. Geological Survey OpenFile Report 77-491, 94 p.

German, E.R., 1983, Water quality of Lakes Faith, Hope, Charity, and Lucien, 1971-79, in an area of residential development and highway construction at Maitland, Florida: U.S. Geological Survey Water-Resources Investigations Report 82-51, $70 \mathrm{p}$.

German, E.R.,1986, Summary of hydrologic conditions in the Reedy Creek Improvement District, Central Florida: U.S. Geological Survey Water-Resources Investigations Report 84-4250, 109 p.

Griffith, G.E., Canfield, D.E., Jr., Horsburgh, C.A., and Omernik, J.M., 1997, Lake regions of Florida: U.S. Environmental Protection Agency EPA/R-97/127, 89 p.

Hampson, P.S., 1993, Hydrology and water quality of Reedy Creek in the Reedy Creek Improvement District, central Florida, 1986-89: U.S. Geological Survey Water-Resources Investigations Report 93-4006, 57 p.

Harper, H.H., and Herr, J.L., 1966, Water quality characteristics and nonpoint source pollutant loadings in the Little Econlockhatchee drainage basin: Orlando, Prepared for Orange County, Florida.

Helsel, D.R., and Hirsch, R.M., 1992, Statistical methods in water resources: Amsterdam, Studies in Environmental Science, v. 49, 522 p.

Interagency Advisory Committee on Water Data, 1982, Guidelines for determining flood-flow frequency: Bulletin 17B of the Hydrology Subcommittee, Office of Water Data Coordination, Reston, Va., U.S. Geological Survey, 183 p.

Kimrey, J.O., 1978, Preliminary appraisal of the geohydrological aspects of drainage wells, Orlando area, central Florida: U.S. Geological Survey Water-Resources Investigations Report 78-37, 24 p.

Knowles, Leel, Jr., 2001, Potentiometric surface of the Upper Floridan aquifer in the St. Johns River Water Management District and vicinity, May 2001: U.S. Geological Survey Open-File Report 01-313, 1 sheet.

Kroening, S.E., 2004, Streamflow and water-quality characteristics at selected sites of the St. Johns River in central Florida, 1933 to 2002: U.S. Geological Survey Scientific Investigations Report 2004-5177, 94 p.

Litchler, W.F., Anderson, Warren, and Joyner, B.F., 1968, Water resources of Orange County, Florida: Tallahassee, Florida Geological Survey Report of Investigations 50, 150 p. 
Litchler, W.F., Hughes, G.H., and Pfischner, F.L., 1976, Hydrologic relations between lakes and aquifers in a recharge area near Orlando, Florida: U.S. Geological Survey WaterResources Investigations Report 76-65, 61 p.

Majewski, M.S., and Capel, P.D., 1995, Pesticides in the atmosphere-Distribution, trends, and governing factors: Chelsea, Michigan, Ann Arbor Press, Inc., 214 p.

Marella, R.L, 1999, Water withdrawals, use, discharge, and trends in Florida, 1995: U.S. Geological Survey WaterResources Investigations Report 99-4002, 90 p.

Marella, R.L., 2004, Water withdrawals, use, discharge, and trends in Florida, 2000: U.S. Geological Survey Scientific Investigations Report 2004-5151, 136 p.

McCann, Kevin, Olson, Lee, Hardy, Patricia, and Wilson, Casey, 1998, 1997 lake water quality report: City of Orlando Stormwater Utility Bureau.

Meinzer, O.E., 1923, The occurrence of ground water in the United States, with a discussion of principles: U.S. Geological Survey Water-Supply Paper 489, 321 p.

Miller \& Miller, 1984, Little Econlockhatchee River restoration study, prepared for the Orange County Board of County Commissioners.

National Oceanic and Atmospheric Administration, 2001, Climatological data annual summary Florida 2000: Asheville, N.C., v. 104, no. 13, 16 p.

O'Dell, K.M., 1994, Water quality in the Shingle Creek Basin, Florida-Before and after wastewater diversion: Journal of Environmental Quality, v. 23, no. 3, p. 563-571.

Orange County Environmental Protection Division, 2002, Lakes and streams-Water quality [accessed April 4, 2002] http://www.orangecountyfl.net/topics/Lakes/default.asp.

O'Reilly, A.M., 1998, Hydrogeology and simulation of the effects of reclaimed-water application in west Orange and southeast Lake Counties, Florida: U.S. Geological Survey Water-Resources Investigations Report 97-4199, 91 p.

Pfischner, F.L., 1968, Relation between land use and chemical characteristics of lakes in southwestern Orange County, Florida: U.S. Geological Survey Professional Paper 600-B, p. 190-194.

Phelps, G.G., and German, E.R., 1995, Water budgets, water quality, and analysis of nutrient loading of the Winter Park chain of lakes, central Florida, 1989-92-With a section on littoral vegetation: U.S. Geological Survey Water-Resources Investigations Report 95-4108, 96 p.

Phelps, G.G., and Schiffer, D.M., 1996, Geohydrology and potential for upward movement of saline water in the Cocoa well field, east Orange County, Florida: U.S. Geological Survey Open-File Report 95-736, 38 p.

Puri, H.S., and Vernon, R.O., 1964, Summary of the geology of Florida and guidebook to the classic exposures: Tallahassee, Florida Geological Survey Special Publication 5 (revised), $255 \mathrm{p}$.

Riggs, H.C., 1968, Frequency curves: U.S. Geological Survey Techniques of Water-Resources Investigations, book 4, chap. A2, $15 \mathrm{p}$.
Rumenik, R.P. and Grubbs, J.W., 1996, Low-flow characteristics of Florida streams: U.S. Geological Survey WaterResources Investigations Report 93-4165, 220 p.

St. Johns River Water Management District, 2004a, Lake Apopka-Cleaning up Florida's most polluted large lake: [accessed November 9, 2004] http://sjr.state.fl.us/programs/ outreach/pubs/order/pdfs/fs_lapopka.pdf.

St. Johns River Water Management District, 2004b, Program overview Lake Apopka Basin: [accessed November 9, 2004] http://sjr.state.fl.us/programs/acq_restoration/s_water/ lapopka/overview.html.

Schiffer, D.M., 1989, Effects of highway runoff on the quality of water and bed sediments of two wetlands in central Florida: U.S. Geological Survey Water-Resources Investigations Report 88-4200, 63 p.

Schiffer, D.M., 1998, Hydrology of central Florida lakeA primer: U.S. Geological Survey Circular 1137, 38 p.

Searcy, J.K., 1959, Flow-duration curves: U.S. Geological Survey Water-Supply Paper 1542-A, 33 p.

Smoot, J.L., and Schiffer, D.M., 1985, Hydrology of Lake Butler, Orange County, Florida: U.S. Geological Survey Water-Resources Investigations Report 84-4163, 1 sheet.

Sumner, D.M., and Bradner, L.A., 1996, Hydraulic characteristics and nutrient transport and transformation beneath a rapid infiltration basin, Reedy Creek Improvement District, Orange County, Florida: U.S. Geological Survey Water-Resources Investigations Report 95-4281, 51 p.

Tibbals, C.H., 1990, Hydrology of the Floridan aquifer system in east-central Florida: U.S. Geological Survey Professional Paper 1403-E, 98 p.

U.S. Environmental Protection Agency, 2000a, Ambient water quality criteria recommendations, information supporting the development of state and tribal nutrient criteria: Rivers and streams in Nutrient Ecoregion XII: Washington, D.C., Office of Water, EPA 822-B-00-021.

U.S. Environmental Protection Agency, 2000b, Ambient water quality criteria recommendations, information supporting the development of state and tribal nutrient criteria: Lakes and reservoirs in Nutrient Ecoregion XII: Washington, D.C., Office of Water, EPA 822-B-00-013.

U.S. Environmental Protection Agency, 2002, Current drinking water standards: [accessed March 8, 2002] http://www.epa. gov/safewater/mcl.html.

U.S. Geological Survey, 2004a, USGS water quality samples for Florida [accessed July 21, 2004] http://nwis.waterdata.usgs. gov/fl/nwis/qwdata.

U.S. Geological Survey, 2004b, USGS, Florida water use: [accessed August 16, 2004] http://fl.water.usgs.gov/WaterUse/Water_Use-web/index.htm.

U.S. Geological Survey, variously dated, National field manual for the collection of water-quality data: U.S. Geological Survey Techniques of Water-Resources Investigations, book 9, chaps. A1-A9, available online at http://pubs.water.usgs. gov/twri9A. [Chapter updates and revisions are ongoing and are summarized at http://water.usgs.gov/owq/FieldManual/ mastererrata.html]. 
Van Dolah, F.M., 2002, Diversity of marine and freshwater algal toxins: National Oceanic and Atmospheric Administration: [accessed March 13, 2002] http://www.chbr.noaa.gov/ CoastalResearch/DiversityEssay.htm.

White, W.A., 1958, Some geomorphic features of central peninsular Florida: Tallahassee, Florida Geological Survey Bulletin $41,92 \mathrm{p}$.

White, W.A., 1970, The geomorphology of the Florida Peninsula: Tallahassee, Florida Geological Survey Bulletin 51, $164 \mathrm{p}$.

Woodward-Clyde Consultants, 1998, Recommended erosion and sedimentation countermeasures, Little Wekiva River Management Plan Contract No. 97W186, Work Order No. 2: Tampa, Fla., Prepared for the St. Johns River Water Management District.
World Health Organization, 2002, WHO's guideline for drinking water: [accessed March 13, 2002] http://www.tcn.zaq.ne.jp/ membrane/english/WhoE.htm.

Zaugg, S.D., Smith, S.G., Schroeder, M.P., Barber, L.B., and Burkhardt, M.R., 2002, Methods of analysis by the U.S. Geological Survey National Water Quality LaboratoryDetermination of wastewater compounds by polystyrenedivinylbenzene solid-phase extraction and capillary-column gas chromatography/mass spectrometry: U.S. Geological Survey Water-Resources Investigations Report 01-4186, $37 \mathrm{p}$. 
Appendixes A-E 
Appendix A. Annual rainfall totals for selected National Oceanographic and Atmospheric Administration stations.

[Rainfall totals are in inches per year]

\begin{tabular}{|c|c|c|c|c|c|c|c|c|c|}
\hline Year & Clermont & $\begin{array}{l}\text { Fort } \\
\text { Drum }\end{array}$ & Kissimmee & Melbourne & Orlando & Sanford & Titusville & $\begin{array}{l}\text { Vero } \\
\text { Beach }\end{array}$ & Lisbon \\
\hline 1931 & 44.26 & & 38.11 & & 42.12 & 42.45 & 37.11 & & \\
\hline 1932 & 38.16 & & 47.11 & & 39.9 & 39.41 & 47.19 & & \\
\hline 1933 & 65.12 & & 65.44 & & 57.42 & 52.86 & 58.67 & & \\
\hline 1934 & 54.43 & & 58.5 & & 50.3 & 58.48 & 47.79 & & \\
\hline 1935 & 54.89 & & 40.44 & & 49.27 & 48.65 & 66.36 & & \\
\hline 1936 & 48.88 & & 45.59 & & 52.18 & 47.34 & 53.91 & & \\
\hline 1937 & 53.34 & & 54.88 & & 59.1 & 49.87 & 49.31 & & \\
\hline 1938 & 37.06 & & 33.03 & 26.39 & 34.55 & 35.54 & 35.18 & & \\
\hline 1939 & 51.3 & & 54.85 & 55.08 & 52.42 & 51.81 & 48.42 & & \\
\hline 1940 & 47.83 & & 49.58 & 42.15 & 54.02 & 48.51 & 55.68 & & \\
\hline 1941 & 52.66 & & 63.1 & 58.78 & 59.65 & 70.73 & 66.38 & & \\
\hline 1942 & 47.11 & & 45.5 & 44.5 & 41.29 & 40.61 & 49.76 & & \\
\hline 1943 & 49.2 & 48.06 & 41.5 & 44.87 & 39.61 & 51.24 & 47.57 & 45.68 & \\
\hline 1944 & 56.11 & 41.5 & 43.34 & 50.01 & 48.85 & 64.91 & 65.57 & 50.72 & \\
\hline 1945 & 53.70 & 47.81 & 50.13 & 56.76 & 55.95 & 57.19 & 60.55 & 47.12 & \\
\hline 1946 & 48.47 & 43.53 & 48.75 & 50.73 & 50.13 & 54.2 & 51.21 & 44.05 & \\
\hline 1947 & 54.15 & 59.4 & 64.55 & 74.16 & 67.47 & 67.38 & 62.22 & 65.57 & \\
\hline 1948 & 46.51 & 50.05 & 50.16 & 56.05 & 52.59 & 52.69 & 58.45 & 63.15 & \\
\hline 1949 & 45.62 & 54.95 & 64.38 & 46.71 & 44.28 & 53.66 & 65.06 & 54.72 & \\
\hline 1950 & 54.79 & 38.31 & 50.55 & 40.9 & 55.96 & 55.78 & 44.06 & 35.23 & \\
\hline 1951 & 52.1 & 53.15 & 54.8 & 47.47 & 57.92 & 54.91 & 66.03 & 53.37 & \\
\hline 1952 & 42.01 & 53.28 & 44.85 & 46.04 & 41.45 & 47.62 & 59.4 & 44.13 & \\
\hline 1953 & 66.87 & 64.4 & 76.27 & 64.02 & 65.85 & 74.06 & 81.74 & 60.97 & \\
\hline 1954 & 35.63 & 56.63 & 41.6 & 46.51 & 48.02 & 45.57 & 48.14 & 55.95 & \\
\hline 1955 & 40.24 & 43.75 & 40.38 & 38.69 & 42.26 & 53.05 & 55.09 & 37.55 & \\
\hline 1956 & 49.22 & 43.8 & 52.41 & 41.13 & 43.91 & 42.48 & 43.62 & 39.43 & \\
\hline 1957 & 52.04 & 60.45 & 60.02 & 57.76 & 50.93 & 55.13 & 66.89 & 63.51 & \\
\hline 1958 & 62.35 & 45.96 & 49.18 & 57.94 & 51.2 & 59.53 & 52.15 & 43.97 & \\
\hline 1959 & 68.09 & 63.89 & 76.36 & 54.84 & 63.77 & 62.28 & 65.63 & 65.78 & 67.58 \\
\hline 1960 & 66.27 & 53.96 & 80.38 & 68.9 & 68.67 & 62.88 & 67.18 & 64.71 & 59.93 \\
\hline 1961 & 32.28 & 35.38 & 28.07 & 41.58 & 41.78 & 37.41 & 41.88 & 32.7 & 33.11 \\
\hline 1962 & 40.33 & 56.28 & 42.53 & 45.23 & 50.35 & 35.04 & 61.87 & 33.81 & 38.66 \\
\hline 1963 & 50.04 & 55.43 & 54.88 & 57.25 & 45.28 & 51.72 & 75.73 & 61.53 & 45.08 \\
\hline 1964 & 55.15 & 46.3 & 49.04 & 50.39 & 54.39 & 57.89 & 62.37 & 45.29 & 51.03 \\
\hline 1965 & 47.81 & 43.74 & 41.09 & 32.52 & 47.4 & 48.8 & 47.27 & 51.2 & 49.67 \\
\hline 1966 & 56.62 & 48.66 & 51.12 & 63.62 & 55.29 & 53.14 & 70.54 & 65.58 & 50.59 \\
\hline 1967 & 53.53 & 42.63 & 43.07 & 40.67 & 40.91 & 41.97 & 48.96 & 37.88 & 40.65 \\
\hline 1968 & 53.39 & 48.98 & 48.92 & 51.17 & 52.1 & 50.56 & 64.37 & 67.01 & 51.7 \\
\hline 1969 & 63.71 & 57.01 & 56.05 & 59.88 & 55.18 & 51.19 & 71.72 & 62.79 & 53.07 \\
\hline 1970 & 48.21 & 35.92 & 41.88 & 38.71 & 43.96 & 45.88 & 53.9 & 45.96 & 36.3 \\
\hline 1971 & 49.77 & 52.08 & 39.46 & 36.55 & 40.09 & 48.72 & 47.99 & 51.93 & 42.5 \\
\hline 1972 & 46.67 & 48.09 & 40.04 & 46.83 & 51.35 & 63.82 & 54.67 & 50.7 & 46.16 \\
\hline 1973 & 54.94 & 62.4 & 54.11 & 47.96 & 55.37 & 51.15 & 51.69 & 68.31 & 52 \\
\hline 1974 & 45.39 & 53.94 & 36.71 & 36.5 & 44.55 & 45.31 & 51.99 & 50.68 & 44.14 \\
\hline 1975 & 49.81 & 55.13 & 50.07 & 43.03 & 47.04 & 50.93 & 45.09 & 45.55 & 45.43 \\
\hline
\end{tabular}


Appendix A. Annual rainfall totals for selected National Oceanographic and Atmospheric Administration stations. (Continued) [Rainfall totals are in inches per year]

\begin{tabular}{|c|c|c|c|c|c|c|c|c|c|}
\hline Year & Clermont & $\begin{array}{l}\text { Fort } \\
\text { Drum }\end{array}$ & Kissimmee & Melbourne & Orlando & Sanford & Titusville & $\begin{array}{c}\text { Vero } \\
\text { Beach }\end{array}$ & Lisbon \\
\hline 1976 & 55.96 & 54.26 & 40.08 & 46.85 & 47.08 & 45.68 & 49.42 & 47.48 & 48.59 \\
\hline 1977 & 40.41 & 45.08 & 48.35 & 45.96 & 38.12 & 45.6 & 42.35 & 47.86 & 40.04 \\
\hline 1978 & 50.79 & 57.2 & 43.48 & 55.2 & 50.59 & 51.07 & 48.66 & 46.26 & 46.63 \\
\hline 1979 & 67.36 & 61.23 & 52.56 & 50.79 & 50.23 & 53.13 & 64.12 & 60.81 & 57.49 \\
\hline 1980 & 40.1 & 37.53 & 30.96 & 35.95 & 41.21 & 48.41 & 40.15 & 39.7 & 42.58 \\
\hline 1981 & 52.19 & 32.74 & 45.36 & 31.97 & 47.1 & 41.67 & 40.83 & 44.73 & 34.43 \\
\hline 1982 & 53.87 & 61.26 & 45.12 & 45.17 & 51.61 & 59.91 & 70.5 & 81.74 & 62.67 \\
\hline 1983 & 57.7 & 64.29 & 63.27 & 57.67 & 55.52 & 62.85 & 65.94 & 67.14 & 53.21 \\
\hline 1984 & 48.75 & 48.6 & 42.37 & 38.53 & 44.44 & 47.71 & 50.59 & 61.81 & 45.01 \\
\hline 1985 & 50.64 & 42.81 & 44.44 & 51.52 & 47.19 & 49.48 & 56.64 & 54.23 & 39.66 \\
\hline 1986 & 48.58 & 48.48 & 39.95 & 39.9 & 49.83 & 43.9 & 40.37 & 62.83 & 43.82 \\
\hline 1987 & 52.85 & 48.79 & 55.83 & 50.38 & 56.79 & 46.23 & 50.32 & 53.23 & 47.19 \\
\hline 1988 & 58.89 & 39.15 & 59.15 & 36.11 & 52.49 & 60.05 & 59.8 & 44.49 & 51.57 \\
\hline 1989 & 49.89 & 50.9 & 50.69 & 42.99 & 45.66 & 40.65 & 45.62 & 45.85 & 47.5 \\
\hline 1990 & 44.58 & 48.14 & 45.36 & 48.02 & 31.68 & 36.38 & 47.24 & 49.13 & 41.94 \\
\hline 1991 & 43.34 & 62.77 & 53.39 & 58.58 & 60.9 & 69.28 & 73.2 & 72.91 & 66.29 \\
\hline 1992 & 53.78 & 60.39 & 54.06 & 49.36 & 52.96 & 59.88 & 58.84 & 60.05 & 55.87 \\
\hline 1993 & 37.92 & 51.74 & 38.87 & 39.29 & 44.53 & 37.21 & 40.18 & 58.2 & 44.31 \\
\hline 1994 & 65.48 & 60.19 & 73.01 & 69.85 & 67.85 & 71.09 & 78.33 & 77.06 & 66.88 \\
\hline 1995 & 52.27 & 64.25 & 48.73 & 70.11 & 43.05 & 59.32 & 49.95 & 51.78 & 52.12 \\
\hline 1996 & 51.64 & 79.21 & 55.80 & 49.52 & 56.66 & 62.82 & 64.29 & 61.66 & 57.9 \\
\hline 1997 & 63.1 & 70.83 & 63.53 & 64.62 & 64.51 & 54.28 & 64.66 & 59.28 & 56.06 \\
\hline 1998 & 34.47 & 79.09 & 43.26 & 55.18 & 43.75 & 48.83 & 43.33 & 62.93 & 42.69 \\
\hline 1999 & 42.66 & 58.59 & 51.98 & 61.51 & 54.8 & 47.04 & 57.49 & 47.28 & 54.13 \\
\hline 2000 & 28.92 & 32.52 & 38.15 & 43.21 & 30.38 & 32.83 & 32.73 & 42.45 & 29.26 \\
\hline
\end{tabular}


Appendix B. Summary of water-level measurements for selected lakes.

[USGS ID is the station identifier used for storage in the U.S. Geological Survey data files. Source of data: 1, U.S. Geological Survey; 2, Orange County Stormwater Management Division]

\begin{tabular}{|c|c|c|c|c|c|c|c|c|c|c|c|}
\hline \multirow[b]{2}{*}{ Lake } & \multirow{2}{*}{ USGS ID } & \multirow{2}{*}{$\begin{array}{l}\text { Source of } \\
\text { data }\end{array}$} & \multirow{2}{*}{$\begin{array}{l}\text { Map No. } \\
\text { (fig. 8) }\end{array}$} & \multirow{2}{*}{$\begin{array}{c}\text { No. } \\
\text { of } \\
\text { measure- } \\
\text { ments }\end{array}$} & \multirow{2}{*}{$\begin{array}{c}\text { First } \\
\text { measurement }\end{array}$} & \multirow{2}{*}{$\begin{array}{c}\text { Last } \\
\text { measurement }\end{array}$} & \multicolumn{5}{|c|}{ Water level (in feet) } \\
\hline & & & & & & & Minimum & P5 & Median & P95 & Maximum \\
\hline Alpharetta & & 2 & 1 & 312 & $9 / 15 / 1959$ & $9 / 15 / 1997$ & 52.11 & 54.06 & 59.87 & 65.69 & 75.12 \\
\hline Anderson & & 2 & 2 & 262 & $1 / 15 / 1960$ & $9 / 15 / 1997$ & 75.02 & 76.36 & 80.33 & 85.27 & 88.66 \\
\hline Apopka & 02237600 & 1 & 3 & 693 & $12 / 15 / 1935$ & $11 / 15 / 1994$ & 64.18 & 65.37 & 66.62 & 68.05 & 69 \\
\hline Avalon & & 2 & 4 & 205 & $1 / 15 / 1960$ & 9/15/1997 & 84.77 & 85.47 & 89.18 & 93.43 & 97.22 \\
\hline Baldwin & 02233450 & 1,2 & 5 & 360 & $3 / 15 / 1943$ & 9/15/1997 & 90.01 & 90.73 & 91.7 & 92.46 & 93.26 \\
\hline Barton (Barton Lake) & & 2 & 8 & 376 & $1 / 15 / 1960$ & $9 / 15 / 1997$ & 60.86 & 63.08 & 64.98 & 65.46 & 66.73 \\
\hline Barton (Big Lake Barton) & & 2 & 6 & 362 & $7 / 15 / 1959$ & 9/15/1997 & 91.61 & 92.29 & 93.04 & 93.79 & 96.13 \\
\hline Barton (Little Lake Barton) & & 2 & 7 & 236 & $8 / 15 / 1960$ & 9/15/1997 & 90.97 & 91.42 & 91.86 & 92.78 & 95.38 \\
\hline Bay & & 2 & 9 & 244 & $8 / 15 / 1960$ & $9 / 15 / 1997$ & 87.6 & 89.14 & 90.4 & 91.15 & 91.9 \\
\hline Bearhead & & 2 & 10 & 184 & $8 / 15 / 1960$ & $9 / 15 / 1997$ & 89.1 & 89.55 & 89.89 & 90.57 & 92.5 \\
\hline Bell & & 2 & 11 & 247 & $7 / 15 / 1959$ & $9 / 15 / 1997$ & 86.93 & 88.11 & 89.32 & 89.84 & 91.39 \\
\hline Berry & & 2 & 12 & 192 & $9 / 15 / 1980$ & 9/15/1997 & 65.33 & 65.87 & 69.37 & 70.79 & 71.58 \\
\hline Big Fairview & & 2 & 13 & 372 & $7 / 15 / 1959$ & 9/15/1997 & 85.69 & 86.84 & 87.76 & 88.54 & 90.22 \\
\hline Black & & 2 & 14 & 187 & $1 / 15 / 1960$ & 9/15/1997 & 90.25 & 91.58 & 93.66 & 97.14 & 98.28 \\
\hline Border & & 2 & 15 & 161 & $7 / 15 / 1959$ & $10 / 15 / 1979$ & 66.56 & 67.93 & 72.06 & 76.89 & 80.34 \\
\hline Bosse & & 2 & 16 & 336 & $8 / 15 / 1960$ & 9/15/1997 & 57.58 & 58.85 & 60.12 & 60.86 & 64.35 \\
\hline Butler & 02263900 & 1,2 & 17 & 778 & $4 / 15 / 1933$ & $8 / 15 / 2001$ & 94.63 & 96.7 & 99.28 & 100.51 & 101.28 \\
\hline Cain & & 2 & 18 & 186 & 7/15/1959 & 9/15/1997 & 96.67 & 97.64 & 98.75 & 99.25 & 99.81 \\
\hline Clear & & 2 & 19 & 368 & $1 / 15 / 1961$ & 9/15/1997 & 92.51 & 93.4 & 94.28 & 94.9 & 97.05 \\
\hline Conway & 02234215 & 1,2 & 20 & 471 & $11 / 15 / 1942$ & 9/15/1997 & 74.38 & 76.03 & 85.66 & 87.04 & 89.04 \\
\hline Crescent & & 2 & 21 & 228 & $1 / 15 / 1960$ & 9/15/1997 & 99.95 & 101 & 102.4 & 103.1 & 103.65 \\
\hline Crooked & & 2 & 22 & 301 & $12 / 15 / 1960$ & 9/15/1997 & 55.97 & 59.97 & 64.8 & 71.61 & 81.9 \\
\hline Daniel & & 2 & 23 & 228 & 6/15/1966 & 9/15/1997 & 89.23 & 89.88 & 90.82 & 91.5 & 92.35 \\
\hline Dora & 02237800 & 1 & 24 & 691 & $11 / 15 / 1935$ & 9/15/1993 & 60.74 & 61.51 & 62.72 & 64.16 & 65 \\
\hline Down & & 2 & 25 & 252 & $1 / 15 / 1960$ & 9/15/1997 & 93.82 & 95.71 & 99.1 & 100.2 & 101.5 \\
\hline Ellenore (Rattlesnake) & & 2 & 26 & 234 & $9 / 15 / 1970$ & $9 / 15 / 1997$ & 93.37 & 94.43 & 95.25 & 95.61 & 96.02 \\
\hline Estelle & & 2 & 27 & 190 & $9 / 15 / 1980$ & 9/15/1997 & 70.72 & 71.14 & 71.6 & 72.42 & 72.87 \\
\hline Fish & & 2 & 28 & 229 & $1 / 15 / 1960$ & 9/15/1997 & 95.42 & 96.33 & 99.23 & 100.3 & 101.7 \\
\hline Formosa & & 2 & 29 & 190 & $9 / 15 / 1980$ & 9/15/1997 & 70.4 & 70.8 & 71.44 & 72.33 & 72.88 \\
\hline Francis & 02237660 & 1 & 30 & 289 & $9 / 15 / 1959$ & $8 / 15 / 1998$ & 53.09 & 54.7 & 57.42 & 63.44 & 66.18 \\
\hline
\end{tabular}


Appendix B. Summary of water-level measurements for selected lakes. (Continued)

[USGS ID is the station identifier used for storage in the U.S. Geological Survey data files. Source of data: 1, U.S. Geological Survey; 2, Orange County Stormwater Management Division]

\begin{tabular}{|c|c|c|c|c|c|c|c|c|c|c|c|}
\hline \multirow[b]{2}{*}{ Lake } & \multirow{2}{*}{ USGS ID } & \multirow{2}{*}{$\begin{array}{c}\text { Source of } \\
\text { data }\end{array}$} & \multirow{2}{*}{$\begin{array}{l}\text { Map No. } \\
\text { (fig. 8) }\end{array}$} & \multirow{2}{*}{$\begin{array}{c}\text { No. } \\
\text { of } \\
\text { measure- } \\
\text { ments }\end{array}$} & \multirow{2}{*}{$\begin{array}{c}\text { First } \\
\text { measurement }\end{array}$} & \multirow{2}{*}{$\begin{array}{c}\text { Last } \\
\text { measurement }\end{array}$} & \multicolumn{5}{|c|}{ Water level (in feet) } \\
\hline & & & & & & & Minimum & P5 & Median & P95 & Maximum \\
\hline Fredrica & & 2 & 31 & 186 & $7 / 15 / 1959$ & $11 / 15 / 1994$ & 95.79 & 96.29 & 97.36 & 98.07 & 99.26 \\
\hline Gandy & & 2 & 32 & 348 & $8 / 15 / 1960$ & $9 / 15 / 1997$ & 64.89 & 67.26 & 71.45 & 73.29 & 75.26 \\
\hline Gatlin & & 2 & 33 & 226 & $10 / 15 / 1970$ & $9 / 15 / 1997$ & 81.29 & 82.9 & 85.59 & 86.84 & 87.45 \\
\hline Gem Mary & & 2 & 34 & 226 & $1 / 15 / 1960$ & $9 / 15 / 1997$ & 86.11 & 87.36 & 89.25 & 90.21 & 92.38 \\
\hline Hancock & & 2 & 35 & 233 & $7 / 15 / 1959$ & 9/15/1997 & 91.01 & 91.58 & 95.69 & 98.2 & 99.4 \\
\hline Hart & 02262200 & 1,2 & 36 & 600 & $11 / 15 / 1941$ & $9 / 15 / 1997$ & 56.63 & 57.81 & 59.93 & 61.46 & 63.55 \\
\hline Hickory Nut & & 2 & 37 & 190 & 7/15/1959 & $9 / 15 / 1997$ & 95.79 & 96.59 & 100.7 & 103.1 & 104.1 \\
\hline Holden & & 2 & 38 & 234 & $7 / 15 / 1959$ & $9 / 15 / 1997$ & 87.81 & 88.97 & 90.3 & 91.37 & 92.15 \\
\hline Horseshoe & & 2 & 39 & 179 & $9 / 15 / 1980$ & 9/15/1997 & 58.87 & 63.72 & 71.64 & 73.1 & 76.64 \\
\hline Ivanhoe & 02234225 & 1,2 & 40 & 338 & $11 / 15 / 1942$ & $10 / 15 / 1979$ & 73.49 & 75.2 & 77.14 & 77.97 & 78.6 \\
\hline Jennie Jewel & & 2 & 41 & 228 & $9 / 15 / 1970$ & 9/15/1997 & 86.83 & 87.85 & 89.62 & 90.39 & 90.98 \\
\hline Jessamine & & 2 & 42 & 367 & $7 / 15 / 1959$ & 9/15/1997 & 89.15 & 89.94 & 91.32 & 92.27 & 93.82 \\
\hline Johns & 02237540 & 1,2 & 43 & 469 & $7 / 15 / 1959$ & $10 / 15 / 1998$ & 85.67 & 88.63 & 92.06 & 96.85 & 99.04 \\
\hline Killarney & & 2 & 44 & 371 & $7 / 15 / 1959$ & 9/15/1997 & 81.11 & 81.9 & 82.58 & 83.57 & 86.03 \\
\hline Lawne & & 2 & 45 & 373 & $7 / 15 / 1959$ & $9 / 15 / 1997$ & 82.7 & 86.28 & 87.49 & 88.27 & 92.49 \\
\hline Little Fairview & & 2 & 46 & 463 & $2 / 15 / 1948$ & 9/15/1997 & 86.79 & 87.93 & 88.96 & 89.95 & 91.33 \\
\hline Lockhart & & 2 & 47 & 228 & $4 / 15 / 1960$ & $9 / 15 / 1997$ & 62.57 & 63.83 & 70.74 & 72.99 & 75.46 \\
\hline Long & & 2 & 48 & 212 & $7 / 15 / 1959$ & $9 / 15 / 1997$ & 52.85 & 54.57 & 64.54 & 74.11 & 80.47 \\
\hline Maitland & 02234300 & 1,2 & 49 & 533 & $5 / 15 / 1945$ & $9 / 15 / 1997$ & 64.15 & 65.32 & 66.23 & 66.63 & 66.96 \\
\hline Mann & & 2 & 50 & 373 & $7 / 15 / 1959$ & $9 / 15 / 1997$ & 86.82 & 89.66 & 90.78 & 91.68 & 96.7 \\
\hline Mary & & 2 & 51 & 247 & $8 / 15 / 1960$ & $9 / 15 / 1997$ & 89.57 & 91.76 & 93.14 & 93.79 & 94.32 \\
\hline Mary Jane & 02261900 & 1,2 & 52 & 620 & $11 / 15 / 1949$ & $7 / 15 / 2001$ & 57.07 & 58.43 & 60.06 & 61.26 & 63.64 \\
\hline Mccoy & & 2 & 53 & 216 & $3 / 15 / 1967$ & $9 / 15 / 1997$ & 52.43 & 55.81 & 60.26 & 61.66 & 62.01 \\
\hline Minnehaha & & 2 & 54 & 231 & $1 / 15 / 1962$ & $9 / 15 / 1997$ & 64.11 & 65.17 & 66.21 & 66.57 & 67.11 \\
\hline Mizell & & 2 & 55 & 200 & $9 / 15 / 1978$ & $9 / 15 / 1997$ & 64.05 & 65.2 & 66.25 & 66.75 & 67.26 \\
\hline Ola & & 2 & 56 & 195 & $7 / 15 / 1959$ & 9/15/1997 & 71.33 & 71.9 & 72.77 & 73.82 & 74.24 \\
\hline Osceola & & 2 & 57 & 198 & $9 / 15 / 1978$ & 9/15/1997 & 64.11 & 65.04 & 66.24 & 66.7 & 67.26 \\
\hline Page & & 2 & 58 & 167 & $1 / 15 / 1960$ & $10 / 15 / 1994$ & 67.85 & 71.74 & 75.87 & 80.14 & 82.86 \\
\hline Park \& Gem & & 2 & 59 & 367 & $11 / 15 / 1960$ & 9/15/1997 & 69.13 & 69.4 & 70.1 & 70.95 & 71.51 \\
\hline Pleasant & & 2 & 60 & 165 & 7/15/1959 & $11 / 15 / 1994$ & 64.07 & 65.87 & 71.18 & 79.6 & 82.21 \\
\hline
\end{tabular}


Appendix B. Summary of water-level measurements for selected lakes. (Continued)

[USGS ID is the station identifier used for storage in the U.S. Geological Survey data files. Source of data: 1, U.S. Geological Survey; 2, Orange County Stormwater Management Division]

\begin{tabular}{|c|c|c|c|c|c|c|c|c|c|c|c|}
\hline \multirow[b]{2}{*}{ Lake } & \multirow[b]{2}{*}{ USGS ID } & \multirow{2}{*}{$\begin{array}{c}\text { Source of } \\
\text { data }\end{array}$} & \multirow{2}{*}{$\begin{array}{l}\text { Map No. } \\
\text { (fig. 8) }\end{array}$} & \multirow{2}{*}{$\begin{array}{c}\text { No. } \\
\text { of } \\
\text { measure- } \\
\text { ments }\end{array}$} & \multirow{2}{*}{$\begin{array}{c}\text { First } \\
\text { measurement }\end{array}$} & \multirow{2}{*}{$\begin{array}{c}\text { Last } \\
\text { measurement }\end{array}$} & \multicolumn{5}{|c|}{ Water level (in feet) } \\
\hline & & & & & & & Minimum & P5 & Median & P95 & Maximum \\
\hline Pocket & & 2 & 61 & 193 & $9 / 15 / 1970$ & $9 / 15 / 1997$ & 94.23 & 95.5 & 99.15 & 100 & 100.5 \\
\hline Prevatt & & 2 & 62 & 205 & $1 / 15 / 1960$ & $9 / 15 / 1997$ & 47.45 & 50.06 & 54.14 & 57.31 & 57.91 \\
\hline Rose & & 2 & 63 & 363 & $1 / 15 / 1960$ & $9 / 15 / 1997$ & 67.78 & 71.93 & 80.07 & 82.48 & 87.03 \\
\hline Sand Lake (Big) & & 2 & 64 & 356 & $7 / 15 / 1959$ & $9 / 15 / 1997$ & 79.43 & 83.73 & 88.75 & 96.33 & 100.4 \\
\hline Sand Lake (Little) & & 2 & 65 & 216 & $1 / 15 / 1960$ & $9 / 15 / 1997$ & 78.59 & 81.35 & 91.97 & 99.44 & 101.8 \\
\hline Sarah & & 2 & 66 & 221 & $3 / 15 / 1967$ & $9 / 15 / 1997$ & 85.95 & 86.82 & 87.7 & 88.33 & 88.97 \\
\hline Shadow & & 2 & 67 & 157 & $8 / 15 / 1960$ & $11 / 15 / 1978$ & 80.14 & 80.61 & 81.19 & 81.58 & 84.25 \\
\hline Sherwood & & 2 & 68 & 343 & $5 / 15 / 1960$ & 9/15/1997 & 54.97 & 58.43 & 65.18 & 79.1 & 87.91 \\
\hline Silver & 02234800 & 1,2 & 69 & 292 & $10 / 15 / 1959$ & 9/15/1997 & 90.4 & 91.23 & 91.97 & 92.39 & 92.88 \\
\hline Spring & & 2 & 70 & 241 & $1 / 15 / 1960$ & $9 / 15 / 1997$ & 92.87 & 94.32 & 98.1 & 104.9 & 111.7 \\
\hline $\begin{array}{l}\text { Spring (North Orange } \\
\text { Blossom Trail) }\end{array}$ & 02234200 & 1,2 & 71 & 400 & $10 / 15 / 1943$ & $8 / 15 / 1997$ & 86.58 & 87.4 & 87.9 & 88.85 & 89.48 \\
\hline Stanley & & 2 & 72 & 165 & $8 / 15 / 1960$ & $11 / 15 / 1994$ & 67.3 & 68.96 & 72.97 & 79.67 & 86.42 \\
\hline Sue & 02234261 & 1,2 & 73 & 478 & $11 / 15 / 1943$ & 9/15/1997 & 69.6 & 70.87 & 72 & 73.1 & 73.72 \\
\hline Susannah & 02233445 & 1,2 & 74 & 270 & $3 / 15 / 1943$ & $9 / 15 / 1997$ & 93.91 & 94.63 & 95.57 & 96.35 & 96.79 \\
\hline Sybelia & & 2 & 75 & 201 & $12 / 15 / 1975$ & $9 / 15 / 1997$ & 66.47 & 67.85 & 70.92 & 72.05 & 73.2 \\
\hline Tibet Butler & & 2 & 76 & 365 & $10 / 15 / 1960$ & 9/15/1997 & 94.46 & 96.25 & 98.94 & 100.1 & 100.8 \\
\hline Turkey & & 2 & 77 & 183 & $1 / 15 / 1960$ & $6 / 15 / 1980$ & 89.34 & 90.16 & 91.96 & 94.12 & 96.85 \\
\hline Tyler & & 2 & 78 & 228 & 9/15/1970 & $9 / 15 / 1997$ & 90.5 & 91.34 & 93.35 & 93.53 & 94.98 \\
\hline Underhill & 02262550 & 1,2 & 79 & 379 & $11 / 15 / 1942$ & $9 / 15 / 1997$ & 95.12 & 96.64 & 97.58 & 98.87 & 99.6 \\
\hline Virginia & & 2 & 80 & 201 & 9/15/1978 & $9 / 15 / 1997$ & 64.05 & 65.09 & 66.24 & 66.69 & 67.26 \\
\hline Warren & & 2 & 81 & 364 & $8 / 15 / 1960$ & $9 / 15 / 1997$ & 83.45 & 84.33 & 85.45 & 86.52 & 87.53 \\
\hline Waunatta & & 2 & 82 & 211 & $1 / 15 / 1960$ & 9/15/1997 & 59.13 & 61.41 & 62.33 & 62.87 & 63.28 \\
\hline Wekiva (Orlando) & & 2 & 83 & 368 & $1 / 15 / 1960$ & $9 / 15 / 1997$ & 81.73 & 82.86 & 83.6 & 84.6 & 86.35 \\
\hline
\end{tabular}


Appendix C. Summary of lake water-quality data.

[Source of data: 1, City of Orlando and U.S. Geological Survey; 2, Orange County; 3, City of Orlando; 4, City of Orlando and Orange County; 5, U.S. Geological Survey; 6 , U.S. Geological Survey, City of Orlando, and Orange County; 7, U.S. Geological Survey and Orange County; mg/L, milligrams per liter, $\mu \mathrm{g} / \mathrm{L}$, micrograms per liter; --, no data]

\begin{tabular}{|c|c|c|c|c|c|c|c|}
\hline \multirow[b]{2}{*}{ Lake } & \multirow[b]{2}{*}{$\begin{array}{l}\text { Latitude } \\
\text { degrees }\end{array}$} & \multirow[b]{2}{*}{$\begin{array}{c}\text { Longitude } \\
\text { degrees }\end{array}$} & \multirow[b]{2}{*}{$\begin{array}{c}\text { Source of } \\
\text { data }\end{array}$} & \multirow[b]{2}{*}{$\begin{array}{c}\text { No. of } \\
\text { samples }\end{array}$} & \multicolumn{3}{|c|}{ Average } \\
\hline & & & & & $\begin{array}{c}\text { Total } \\
\text { phosphorus } \\
(\mathrm{mg} / \mathrm{L})\end{array}$ & $\begin{array}{c}\text { Total } \\
\text { nitrogen } \\
\text { (mg/L) }\end{array}$ & $\begin{array}{c}\text { Chlorophyll-a } \\
(\mu \mathrm{g} / \mathrm{L})\end{array}$ \\
\hline Adair & 28.560 & 81.391 & 1 & 4 & 0.04 & 1.06 & 39.2 \\
\hline Anderson & 28.499 & 81.337 & 2 & 4 & .01 & 1.16 & 20.2 \\
\hline Angel & 28.517 & 81.388 & 3 & 2 & .14 & .90 & 38.0 \\
\hline Arnold & 28.531 & 81.341 & 3 & 5 & .02 & .71 & 22.9 \\
\hline Baldwin & 28.572 & 81.322 & 4 & 5 & .01 & .65 & 11.2 \\
\hline Barton & 28.551 & 81.316 & 4 & 3 & .01 & .79 & 15.8 \\
\hline Bay & 28.591 & 81.422 & 3 & 6 & .04 & 1.39 & 31.8 \\
\hline Beardall & 28.536 & 81.402 & 1 & 3 & .13 & 1.32 & 24.8 \\
\hline Beauclair & 28.771 & 81.651 & 5 & 1 & .11 & 5.10 & 200.0 \\
\hline Bessie & 28.488 & 81.527 & 2 & 4 & .01 & .54 & 1.6 \\
\hline Big Sand (middle/north) & 28.434 & 81.490 & 2 & 2 & .01 & .92 & 3.4 \\
\hline Blanche & 28.481 & 81.516 & 2 & 2 & .01 & .58 & 1.5 \\
\hline Buck & 28.409 & 81.249 & 3 & 4 & .01 & .55 & 2.1 \\
\hline Burkett & 28.610 & 81.268 & 2 & 4 & .01 & 1.24 & 22.7 \\
\hline Butler & 28.490 & 81.554 & 2 & 2 & .01 & .65 & 1.1 \\
\hline $\mathrm{C}$ & 28.531 & 81.318 & 3 & 4 & .06 & .81 & 35.7 \\
\hline Cane & 28.485 & 81.473 & 4 & 2 & .01 & .78 & 8.4 \\
\hline Carlton & 28.759 & 81.658 & 2 & 3 & .01 & 4.90 & 113.6 \\
\hline Cay Dee (south) & 28.563 & 81.345 & 3 & 3 & .01 & .83 & 7.9 \\
\hline Crescent & 28.508 & 81.561 & 2 & 5 & .01 & .61 & 1.8 \\
\hline Daniel & 28.582 & 81.402 & 3 & 3 & .03 & .98 & 17.7 \\
\hline Davis & 28.531 & 81.366 & 3 & 1 & .38 & 1.15 & 54.7 \\
\hline Dot & 28.552 & 81.387 & 3 & 4 & .04 & .67 & 17.5 \\
\hline Down & 28.504 & 81.528 & 2 & 5 & .01 & .35 & .8 \\
\hline Ellenore & 28.491 & 81.397 & 5 & 1 & .03 & 1.00 & 7.5 \\
\hline Eola & 28.544 & 81.373 & 3 & 3 & .05 & .82 & 28.7 \\
\hline Estelle (west) & 28.575 & 81.366 & 3 & 3 & .04 & .83 & 21.0 \\
\hline Fairview & 28.594 & 81.407 & 6 & 4 & .01 & .66 & 5.5 \\
\hline Farrar & 28.508 & 81.321 & 3 & 5 & .01 & .43 & 4.0 \\
\hline Formosa & 28.568 & 81.369 & 4 & 4 & .02 & .87 & 19.0 \\
\hline Fredrica & 28.508 & 81.307 & 4 & 5 & .01 & .46 & 3.0 \\
\hline Gandy & 28.628 & 81.433 & 2 & 1 & .01 & .95 & 2.4 \\
\hline Gear & 28.556 & 81.331 & 3 & 2 & .01 & .58 & 3.8 \\
\hline Gem Mary & 28.496 & 81.365 & 4 & 3 & .02 & .68 & 17.6 \\
\hline George & 28.501 & 81.320 & 4 & 7 & .01 & .40 & 2.6 \\
\hline
\end{tabular}




\section{$94 \quad$ Hydrology and Water Quality of Lakes and Streams in Orange County, Florida}

Appendix C. Summary of lake water-quality data. (Continued)

[Source of data: 1, City of Orlando and U.S. Geological Survey; 2, Orange County; 3 , City of Orlando; 4, City of Orlando and Orange County; 5, U.S. Geological Survey; 6 , U.S. Geological Survey, City of Orlando, and Orange County; 7, U.S. Geological Survey and Orange County; mg/L, milligrams per liter, $\mu \mathrm{g} / \mathrm{L}$, micrograms per liter; --, no data]

\begin{tabular}{|c|c|c|c|c|c|c|c|}
\hline \multirow[b]{2}{*}{ Lake } & \multirow[b]{2}{*}{$\begin{array}{l}\text { Latitude } \\
\text { degrees }\end{array}$} & \multirow[b]{2}{*}{$\begin{array}{c}\text { Longitude } \\
\text { degrees }\end{array}$} & \multirow[b]{2}{*}{$\begin{array}{c}\text { Source of } \\
\text { data }\end{array}$} & \multirow[b]{2}{*}{$\begin{array}{c}\text { No. of } \\
\text { samples }\end{array}$} & \multicolumn{3}{|c|}{ Average } \\
\hline & & & & & $\begin{array}{c}\text { Total } \\
\text { phosphorus } \\
\text { (mg/L) }\end{array}$ & $\begin{array}{c}\text { Total } \\
\text { nitrogen } \\
(\mathrm{mg} / \mathrm{L})\end{array}$ & $\begin{array}{c}\text { Chlorophyll-a } \\
(\mu \mathrm{g} / \mathrm{L})\end{array}$ \\
\hline Georgia & 28.606 & 81.246 & 4 & 1 & 0.01 & 0.60 & 3.7 \\
\hline Giles & 28.530 & 81.334 & 3 & 4 & .03 & .66 & 16.0 \\
\hline Greenwood & 28.533 & 81.360 & 3 & 3 & .07 & .57 & 12.3 \\
\hline Hart & 28.385 & 81.214 & 7 & 4 & .02 & 1.28 & 5.9 \\
\hline Hiawassee & 28.528 & 81.481 & 3 & 2 & .02 & .79 & 4.3 \\
\hline Hickorynut (middle) & 28.427 & 81.642 & 7 & 5 & .01 & .76 & .9 \\
\hline Highland & 28.560 & 81.370 & 3 & 4 & .03 & .81 & 19.0 \\
\hline Holden & 28.503 & 81.384 & 4 & 5 & .03 & 1.85 & 38.3 \\
\hline Hope & 28.640 & 81.371 & 5 & 2 & .03 & .82 & 4.4 \\
\hline Ivanhoe (middle) & 28.563 & 81.380 & 6 & 4 & .02 & .72 & 11.9 \\
\hline Ivanhoe (west) & 28.565 & 81.383 & 4 & 5 & .02 & .78 & 18.4 \\
\hline Jackson & 28.667 & 81.464 & 5 & 1 & .01 & .72 & 5.6 \\
\hline Jennie Jewel (west) & 28.497 & 81.370 & 2 & 3 & .01 & .93 & 25.0 \\
\hline Jessamine (middle) & 28.481 & 81.386 & 2 & 1 & .01 & 1.10 & 16.2 \\
\hline John's & 28.526 & 81.675 & 5 & 1 & .09 & 2.33 & 16.0 \\
\hline Kasey & 28.598 & 81.443 & 3 & 4 & .08 & 1.36 & 47.1 \\
\hline Kelly & 28.598 & 81.448 & 3 & 1 & .03 & .34 & 4.9 \\
\hline Killarney & 28.601 & 81.381 & 2 & 3 & .01 & .85 & 15.0 \\
\hline Kozart & 28.526 & 81.443 & 3 & 3 & .19 & 3.26 & 57.4 \\
\hline Louise & 28.591 & 81.098 & 7 & 4 & .02 & .88 & 6.3 \\
\hline Lucerne (east) & 28.534 & 81.379 & 3 & 4 & .04 & .72 & 15.6 \\
\hline Lucerne (west) & 28.534 & 81.379 & 3 & 4 & .03 & .65 & 25.4 \\
\hline Lurna & 28.523 & 81.374 & 3 & 3 & .08 & .69 & 29.7 \\
\hline Maitland & 28.620 & 81.350 & 7 & 4 & .01 & .91 & 14.5 \\
\hline Mann & 28.537 & 81.426 & 3 & 5 & .05 & 1.65 & 36.1 \\
\hline Marsha & 28.478 & 81.483 & 2 & 1 & .01 & .45 & 1.4 \\
\hline Marshall & 28.676 & 81.533 & 5 & 1 & .14 & 5.50 & 180.0 \\
\hline Mary Jane & 28.374 & 81.179 & 7 & 3 & .02 & 1.30 & 6.2 \\
\hline Minnehaha & 28.630 & 81.355 & 2 & 1 & .01 & 1.10 & 31.1 \\
\hline Mizell & 28.593 & 81.338 & 2 & 1 & .01 & .57 & 14.4 \\
\hline Monterey & 28.532 & 81.313 & 3 & 2 & .08 & .87 & 32.8 \\
\hline Mud & 28.389 & 81.292 & 3 & 3 & .04 & .83 & 5.0 \\
\hline Nan & 28.608 & 81.281 & 2 & 4 & 0.01 & .63 & 8.3 \\
\hline Nona & 28.408 & 81.272 & 4 & 5 & .01 & .43 & 1.6 \\
\hline Ola & 28.754 & 81.637 & 5 & 3 & .01 & .78 & 9.3 \\
\hline Olive & 28.539 & 81.367 & 6 & 4 & 0.04 & 1.02 & 20.8 \\
\hline Oliver & 28.369 & 81.648 & 6 & 1 & .01 & .47 & -- \\
\hline
\end{tabular}


Appendix C. Summary of lake water-quality data. (Continued)

[Source of data: 1, City of Orlando and U.S. Geological Survey; 2, Orange County; 3, City of Orlando; 4, City of Orlando and Orange County; 5, U.S. Geological Survey; 6 , U.S. Geological Survey, City of Orlando, and Orange County; 7, U.S. Geological Survey and Orange County; mg/L, milligrams per liter, $\mu \mathrm{g} / \mathrm{L}$, micrograms per liter; --, no data]

\begin{tabular}{|c|c|c|c|c|c|c|c|}
\hline \multirow[b]{2}{*}{ Lake } & \multirow[b]{2}{*}{$\begin{array}{l}\text { Latitude } \\
\text { degrees }\end{array}$} & \multirow[b]{2}{*}{$\begin{array}{l}\text { Longitude } \\
\text { degrees }\end{array}$} & \multirow[b]{2}{*}{$\begin{array}{l}\text { Source of } \\
\text { data }\end{array}$} & \multirow[b]{2}{*}{$\begin{array}{l}\text { No. of } \\
\text { samples }\end{array}$} & \multicolumn{3}{|c|}{ Average } \\
\hline & & & & & $\begin{array}{c}\text { Total } \\
\text { phosphorus } \\
\text { (mg/L) }\end{array}$ & $\begin{array}{c}\text { Total } \\
\text { nitrogen } \\
(\mathrm{mg} / \mathrm{L})\end{array}$ & $\begin{array}{c}\text { Chlorophyll-a } \\
(\mu \mathrm{g} / \mathrm{L})\end{array}$ \\
\hline Olivia & 28.521 & 81.518 & 2 & 1 & .01 & .63 & 5.3 \\
\hline Olympia & 28.569 & 81.524 & 2 & 1 & .01 & .78 & 11.5 \\
\hline Osceola & 28.604 & 81.343 & 2 & 2 & .01 & .98 & 31.8 \\
\hline Pamela & 28.521 & 81.462 & 3 & 4 & .03 & 1.41 & 10.8 \\
\hline Park & 28.616 & 81.371 & 3 & 3 & .05 & 1.09 & 23.1 \\
\hline Pineloch & 28.507 & 81.367 & 4 & 6 & .02 & .63 & 9.5 \\
\hline Pocket & 28.421 & 81.513 & 2 & 6 & .01 & .58 & 2.4 \\
\hline $\begin{array}{l}\text { Pond at Tosohatchee State Park } \\
\text { near Christmas }\end{array}$ & 28.449 & 80.939 & 5 & 2 & .05 & 1.17 & 16.1 \\
\hline Price & 28.598 & 81.175 & 2 & 1 & .01 & .64 & 1.1 \\
\hline Rabama & 28.520 & 81.329 & 3 & 4 & .05 & .62 & 7.0 \\
\hline Raccoon & 28.351 & 81.629 & 5 & 1 & .02 & .84 & 5.2 \\
\hline Red & 28.405 & 81.259 & 2 & 1 & .01 & .73 & 21.4 \\
\hline Reedy & 28.414 & 81.617 & 5 & 1 & .03 & .83 & 6.8 \\
\hline Richmond & 28.512 & 81.434 & 3 & 3 & .06 & 1.87 & 51.5 \\
\hline Rock & 28.547 & 81.401 & 3 & 5 & .03 & .66 & 12.3 \\
\hline Rowena & 28.571 & 81.360 & 4 & 6 & .03 & .84 & 31.9 \\
\hline Sandy & 28.540 & 81.466 & 3 & 3 & .08 & .82 & 8.8 \\
\hline Sarah & 28.585 & 81.403 & 3 & 4 & .02 & .92 & 19.8 \\
\hline Sawyer & 28.469 & 81.568 & 2 & 1 & .01 & 1.10 & 12.4 \\
\hline Starke & 28.568 & 81.536 & 2 & 3 & .01 & 1.17 & 22.4 \\
\hline Sue & 28.577 & 81.354 & 4 & 2 & .02 & .66 & 15.5 \\
\hline Sunset & 28.536 & 81.412 & 3 & 4 & .02 & 1.08 & 9.7 \\
\hline Susannah & 28.562 & 81.323 & 3 & 4 & .02 & .79 & 16.5 \\
\hline Sybellia & 28.628 & 81.371 & 2 & 3 & .01 & .83 & 9.4 \\
\hline Tennessee & 28.510 & 81.332 & 3 & 4 & .04 & .65 & 11.2 \\
\hline Terrace & 28.521 & 81.346 & 3 & 4 & .04 & 1.28 & 17.5 \\
\hline Tibet-Butler & 28.454 & 81.524 & 2 & 6 & .01 & .48 & 1.1 \\
\hline Turkey & 28.505 & 81.475 & 5 & 3 & .03 & .78 & 10.2 \\
\hline Underhill & 28.536 & 81.337 & 6 & 4 & .01 & 1.19 & 34.0 \\
\hline Virginia & 28.589 & 81.345 & 2 & 3 & .01 & 1.20 & 32.3 \\
\hline Wade & 28.516 & 81.368 & 3 & 3 & .11 & 1.23 & 32.4 \\
\hline Walker & 28.524 & 81.424 & 3 & 2 & .16 & 1.78 & 30.1 \\
\hline Warren & 28.460 & 81.323 & 4 & 4 & .06 & 1.56 & 30.4 \\
\hline Wekiva (Orlando) & 28.598 & 81.432 & 4 & 3 & .06 & 1.36 & 35.6 \\
\hline $\begin{array}{l}\text { Whippoorwill (also known as } \\
\text { Barton Lake) }\end{array}$ & 28.388 & 81.236 & 2 & 2 & .01 & .51 & 5.2 \\
\hline Winyah & 28.578 & 81.368 & 3 & 4 & .06 & .90 & 35.1 \\
\hline
\end{tabular}


Appendix D. Field measurements and concentrations of major ions, nutrients, and trace elements in samples collected from lakes during this study, $2000-2001$.

[All concentrations dissolved, except where noted; DMS, degrees, minutes, seconds; $\mu \mathrm{g} / \mathrm{L}$, micrograms per liter; $\mu \mathrm{S} / \mathrm{cm}$, microsiemens per centimeter; $\mathrm{mg} / \mathrm{L}$, milligrams per liter; ${ }^{\circ} \mathrm{C}$, degrees $\mathrm{Celsius;} \mathrm{CaCO}{ }_{3}$, calcium carbonate; $\mathrm{SO}_{4}$, sulfate; $\mathrm{SiO}_{2}$, silicon dioxide; $\mathrm{N}$, nitrogen, $\mathrm{P}$, phosphorus]

\begin{tabular}{|c|c|c|c|c|c|c|c|c|c|c|}
\hline Site identifier & Site name & $\begin{array}{c}\text { Map } \\
\text { No. } \\
\text { (fig. 9) }\end{array}$ & $\begin{array}{l}\text { Latitude } \\
\text { (DMS) }\end{array}$ & $\begin{array}{l}\text { Longitude } \\
\text { (DMS) }\end{array}$ & Date & $\begin{array}{c}\text { Specific } \\
\text { conduc- } \\
\text { tance, } \\
\text { field } \\
(\mu \mathrm{S} / \mathrm{cm})\end{array}$ & $\begin{array}{c}\text { Specific } \\
\text { conduc- } \\
\text { tance, } \\
\text { lab } \\
(\mu \mathrm{S} / \mathrm{cm})\end{array}$ & $\begin{array}{c}\text { pH, field } \\
\text { (standard } \\
\text { units) }\end{array}$ & $\begin{array}{c}\text { pH, lab } \\
\text { (standard } \\
\text { units) }\end{array}$ & $\begin{array}{c}\text { Water } \\
\text { temp- } \\
\text { erature } \\
\left({ }^{\circ} \mathrm{C}\right)\end{array}$ \\
\hline 02237540 & Johns Lake at Oakland ${ }^{1}$ & 1 & 283230 & 0813828 & $5 / 10 / 2001$ & 406 & 410 & 7.5 & 7.4 & 22.8 \\
\hline 02234205 & Lake Adair at Orlando ${ }^{1}$ & 2 & 283329 & 0812320 & $5 / 29 / 2001$ & 211 & 214 & 7.7 & 7.5 & 28.5 \\
\hline 284617081390200 & Lake Beauclair (eastern shore) near Mt. Dora ${ }^{1}$ & 3 & 284617 & 0813902 & $11 / 2 / 2000$ & 478 & 484 & 9.0 & 7.4 & 24.2 \\
\hline 02234812 & Lake Fairview at Orlando ${ }^{1}$ & 4 & 283522 & 0812420 & $7 / 12 / 2000$ & 187 & 178 & 7.7 & 7.9 & 30.0 \\
\hline 02234812 & Lake Fairview at Orlando & & 283522 & 0812420 & $11 / 6 / 2000$ & 167 & 167 & 6.7 & 7.6 & 23.4 \\
\hline 02234812 & Lake Fairview at Orlando & & 283522 & 0812420 & $4 / 23 / 2001$ & 178 & 178 & 7.2 & 7.7 & 23.9 \\
\hline 02262200 & Lake Hart near Narcoossee ${ }^{1}$ & 5 & 282246 & 0811327 & $7 / 20 / 2000$ & 91 & 92 & 5.6 & 5.9 & 30.0 \\
\hline 02262200 & Lake Hart near Narcoossee & & 282246 & 0811327 & $10 / 30 / 2000$ & 98 & 97 & 6.2 & 5.9 & 22.8 \\
\hline 02262200 & Lake Hart near Narcoossee & & 282246 & 0811327 & $5 / 8 / 2001$ & 115 & 117 & 5.9 & 6.0 & 23.3 \\
\hline 02266275 & Hickorynut Lake near Oakland ${ }^{1}$ & 6 & 282540 & 0813840 & $7 / 18 / 2000$ & 177 & 177 & 6.0 & 7.1 & 30.4 \\
\hline 02266275 & Hickorynut Lake near Oakland & & 282540 & 0813840 & $4 / 26 / 2001$ & 206 & 207 & 7.2 & 7.0 & 24.5 \\
\hline 02234297 & Lake Hope at Maitland ${ }^{1}$ & 7 & 283824 & 0812215 & $7 / 19 / 2000$ & 317 & 317 & 6.4 & 7.2 & 33.4 \\
\hline 02234297 & Lake Hope at Maitland & & 283824 & 0812215 & $11 / 1 / 2000$ & 328 & 326 & 7.1 & 7.0 & 22.8 \\
\hline 02234225 & Lake Ivanhoe at Orlando ${ }^{1}$ & 8 & 283326 & 0812234 & $11 / 6 / 2000$ & 211 & 212 & 8.0 & 7.4 & 24.0 \\
\hline 284000081275000 & Lake Jackson near Apopka ${ }^{1}$ & 9 & 284000 & 0812750 & $5 / 30 / 2001$ & 212 & 214 & 7.2 & 7.3 & 28.3 \\
\hline 283305081304200 & Lake Lotta near Ocoee & 10 & 283304 & 0813048 & $11 / 20 / 2000$ & 213 & 209 & 6.5 & 7.4 & 20.8 \\
\hline 283528081055300 & Lake Louise near Bithlo ${ }^{1}$ & 11 & 283528 & 0810553 & $7 / 19 / 2000$ & 151 & 151 & 6.1 & 6.5 & 30.2 \\
\hline 283528081055300 & Lake Louise near Bithlo & & 283528 & 0810553 & $11 / 1 / 2000$ & 150 & 153 & 6.9 & 6.6 & 23.5 \\
\hline 283528081055300 & Lake Louise near Bithlo & & 283528 & 0810553 & $5 / 7 / 2001$ & 174 & 176 & 6.4 & 6.4 & 24.2 \\
\hline 02234300 & Lake Maitland at Winter Park ${ }^{1}$ & 12 & 283649 & 0812035 & $5 / 9 / 2001$ & 231 & 232 & 8.1 & 7.7 & \\
\hline 02261900 & Lake Mary Jane near Narcoossee $^{1}$ & 13 & 282246 & 0811115 & $10 / 30 / 2000$ & 100 & 105 & 6.2 & 6.0 & 22.9 \\
\hline 02237745 & Lake Ola at Tangerine $^{1}$ & 14 & 284510 & 0813800 & $7 / 18 / 2000$ & 303 & 302 & 6.6 & 7.8 & 29.7 \\
\hline 02237745 & Lake Ola at Tangerine & & 284510 & 0813800 & $11 / 2 / 2000$ & 308 & 304 & 6.5 & 7.4 & 23.0 \\
\hline 02237745 & Lake Ola at Tangerine & & 284510 & 0813800 & $4 / 23 / 2001$ & 325 & 325 & 7.2 & 7.6 & 23.2 \\
\hline 282210081385100 & Lake Oliver near Vineland & 15 & 282210 & 0813851 & $11 / 20 / 2000$ & 57 & 55 & & 5.1 & 20.4 \\
\hline 283219081201302 & Lake Underhill $^{1}$ & 16 & 283219 & 0812013 & $5 / 9 / 2001$ & 175 & 178 & 8.1 & 7.5 & 23.8 \\
\hline 284034081315700 & Marshall Lake near Apopka & 17 & 284034 & 0813157 & $5 / 30 / 2001$ & 322 & 339 & 8.3 & 7.0 & 28.2 \\
\hline 282927081235000 & Lake Ellenore near Pine Castle ${ }^{1}$ & 18 & 282927 & 0812350 & $5 / 21 / 2001$ & 169 & 175 & 7.1 & 7.3 & 26.4 \\
\hline 282657080561900 & Pond at Tosohatchee State Park near Christmas ${ }^{1}$ & 19 & 282657 & 0805619 & $11 / 8 / 2000$ & 450 & 444 & 6.2 & 7.2 & 21.5 \\
\hline 282657080561900 & Pond at Tosohatchee State Park near Christmas & & 282657 & 0805619 & $4 / 24 / 2001$ & 558 & 560 & 6.9 & 7.3 & 22.5 \\
\hline 282702080554200 & Pond No. 2 at Tosohatchee near Christmas ${ }^{1}$ & 20 & 282702 & 0805542 & $4 / 24 / 2001$ & 1,185 & 1,190 & 7.7 & 8.6 & 25.3 \\
\hline 282102081374600 & Raccoon Lake near Windermere & 21 & 282102 & 0813746 & $5 / 24 / 2001$ & 206 & 208 & & 7.1 & 28.6 \\
\hline 282452081370200 & Reedy Lake near Vineland ${ }^{1}$ & 22 & 282452 & 0813702 & $5 / 24 / 2001$ & 543 & 548 & 7.5 & 7.3 & 25.7 \\
\hline 282450081375100 & Sink on Hartzog Road near Vineland & 23 & 282450 & 0813751 & $11 / 15 / 2000$ & 397 & 390 & 6.3 & 7.0 & 21.5 \\
\hline 283019081283100 & Turkey Lake at Orlando ${ }^{1}$ & 24 & 283019 & 0812831 & $7 / 13 / 2000$ & 200 & 188 & 7.1 & 7.3 & 31.0 \\
\hline 283019081283100 & Turkey Lake at Orlando & & 283019 & 0812831 & $10 / 31 / 2000$ & 197 & 196 & 6.8 & 7.1 & 23.4 \\
\hline 283019081283100 & Turkey Lake at Orlando & & 283019 & 0812831 & $4 / 26 / 2001$ & 226 & 226 & 6.8 & 6.6 & 23.5 \\
\hline
\end{tabular}

${ }^{1}$ Field measurements were obtained at various depths. 
Appendix D. Field measurements and concentrations of major ions, nutrients, and trace elements in samples collected from lakes during this study, 2000-2001. (Continued)

[All concentrations dissolved, except where noted; DMS, degrees, minutes, seconds; $\mu \mathrm{g} / \mathrm{L}$, micrograms per liter; $\mu \mathrm{S} / \mathrm{cm}$, microsiemens per centimeter; $\mathrm{mg} / \mathrm{L}$, milligrams per liter; ${ }^{\circ} \mathrm{C}$, degrees $\mathrm{Celsius;} \mathrm{CaCO}{ }_{3}$, calcium carbonate; $\mathrm{SO}_{4}$, sulfate; $\mathrm{SiO}_{2}$, silicon dioxide; $\mathrm{N}$, nitrogen, $\mathrm{P}$, phosphorus]

\begin{tabular}{|c|c|c|c|c|c|c|c|c|c|c|c|c|c|}
\hline Site identifier & $\begin{array}{c}\text { Trans- } \\
\text { parency } \\
\text { (inches) }\end{array}$ & $\begin{array}{l}\text { Oxygen, } \\
\text { dissolved } \\
(\mathrm{mg} / \mathrm{L})\end{array}$ & $\begin{array}{c}\text { Calcium } \\
\text { (mg/L) }\end{array}$ & $\begin{array}{l}\text { Magneium } \\
(\mathrm{mg} / \mathrm{L})\end{array}$ & $\begin{array}{c}\text { Sodium } \\
\text { (mg/L) }\end{array}$ & $\begin{array}{l}\text { Potassium } \\
\quad(\mathrm{mg} / \mathrm{L})\end{array}$ & $\begin{array}{c}\text { Acid } \\
\text { neutralizing } \\
\text { capacity } \\
(\mathrm{mg} / \mathrm{L} \text { as } \\
\left.\mathrm{CaCO}_{3}\right)\end{array}$ & $\begin{array}{c}\text { Chloride } \\
\text { (mg/L) }\end{array}$ & $\begin{array}{c}\text { Sulfate } \\
(\mathrm{mg} / \mathrm{L} \text { as } \\
\left.\mathrm{SO}_{4}\right)\end{array}$ & $\begin{array}{c}\text { Fluoride } \\
\text { (mg/L) }\end{array}$ & $\begin{array}{c}\text { Bromide } \\
\text { (mg/L) }\end{array}$ & $\begin{array}{c}\text { Silica } \\
(\mathrm{mg} / \mathrm{L} \text { as } \\
\left.\mathrm{SiO}_{2}\right)\end{array}$ & $\begin{array}{c}\text { Residue on } \\
\text { evaporation } \\
\text { (mg/L at } \\
\left.180^{\circ} \mathrm{C}\right)\end{array}$ \\
\hline 02237540 & 14 & 6.5 & 17 & 14 & 28 & 19 & 38 & 51 & 70 & 0.31 & 0.25 & 1.3 & 262 \\
\hline 02234205 & 48 & 7.5 & 23 & 4.2 & 13 & 4.2 & 52 & 21 & 16 & .18 & .06 & .24 & 132 \\
\hline 284617081390200 & 14 & & 39 & 19 & 18 & 13 & 139 & 45 & 32 & .41 & .2 & 4.3 & 329 \\
\hline 02234812 & & 8.9 & 20 & 2.7 & 10 & 2.2 & 51 & 15 & 13 & .1 & $<.05$ & .2 & 109 \\
\hline 02234812 & 96 & 8.1 & 17 & 2.9 & 10 & 2.4 & 41 & 16 & 14 & .1 & .07 & .3 & 101 \\
\hline 02234812 & 96 & 8.1 & 18 & 3 & 11 & 2.4 & 44 & 18 & 15 & .11 & $<5$ & .17 & 107 \\
\hline 02262200 & 28 & & 4.6 & 1.9 & 8.6 & 1.3 & 6.6 & 16 & 7.3 & $<.1$ & $<.05$ & 1.3 & 99 \\
\hline 02262200 & 29 & 8.0 & 4.5 & 2 & 9.5 & 1.5 & 4.8 & 17 & 8 & $<.1$ & .11 & 1.2 & 86 \\
\hline 02262200 & 24 & 8.2 & 5.3 & 2.3 & 12 & 1.7 & 4.8 & 22 & 11 & $<.1$ & .08 & .96 & 101 \\
\hline 02266275 & 114 & 7.0 & 5.7 & 5.6 & 13 & 7.8 & 12 & 25 & 25 & $<.1$ & .07 & .2 & 121 \\
\hline 02266275 & & 8.0 & 6.7 & 6.1 & 16 & 8.6 & 12 & 29 & 30 & $<.1$ & 1.2 & .07 & 131 \\
\hline 02234297 & 48 & & 19 & 4.3 & 30 & 4.7 & 27 & 53 & 37 & $<.1$ & $<.05$ & .5 & 193 \\
\hline 02234297 & & 3.3 & 20 & 4.3 & 31 & 5.1 & 26 & 54 & 40 & $<.1$ & .1 & .5 & 190 \\
\hline 02234225 & 42 & 7.7 & 26 & 3.7 & 9.3 & 2.7 & 62 & 15 & 17 & .13 & $<.05$ & .5 & 128 \\
\hline 284000081275000 & 72 & 5.4 & 19 & 3.6 & 13 & 4.2 & 33 & 26 & 23 & $<.1$ & .06 & .59 & 134 \\
\hline 283305081304200 & & 7.3 & 23 & 5.7 & 7.3 & 4.8 & 55 & 12 & 25 & .21 & $<.05$ & 3.6 & 143 \\
\hline 283528081055300 & 20 & & 5.7 & 1.7 & 18 & 2.2 & 8.8 & 30 & 9.9 & $<.1$ & $<.05$ & 2.2 & 111 \\
\hline 283528081055300 & 50 & 7.3 & 5.3 & 1.8 & 19 & 2.4 & 7.1 & 31 & 11 & $<.1$ & $<.05$ & 2.2 & 106 \\
\hline 283528081055300 & $<12$ & 7.0 & 6.3 & 1.9 & 22 & 2.4 & 6 & 38 & 14 & $<.1$ & .07 & .92 & 111 \\
\hline 02234300 & 78 & 8.5 & 22 & 4.2 & 13 & 2.6 & 39 & 27 & 30 & .1 & .08 & .14 & 143 \\
\hline 02261900 & 24 & 7.1 & 4.8 & 1.9 & 11 & 1.3 & 5.5 & 19 & 6.9 & $<.1$ & $<.05$ & 1.5 & 101 \\
\hline 02237745 & 120 & 7.4 & 20 & 9.9 & 14 & 12 & 42 & 31 & 51 & .11 & .06 & .7 & 192 \\
\hline 02237745 & 110 & 7.7 & 20 & 9.9 & 14 & 12 & 39 & 31 & 54 & .1 & $<.05$ & .7 & 193 \\
\hline 02237745 & & 8.2 & 21 & 10 & 15 & 13 & 36 & 33 & 60 & .1 & $<5$ & .3 & 194 \\
\hline 282210081385100 & & 7.7 & 1.6 & 1.2 & 5.7 & 0.3 & 3 & 9.8 & 3.3 & $<.1$ & $<.05$ & 4.6 & 51 \\
\hline 283219081201302 & 30 & 8.8 & 24 & 2 & 7.4 & 1.8 & 58 & 12 & 12 & .1 & $<.05$ & .19 & 108 \\
\hline 284034081315700 & 12 & 7.9 & 28 & 8.3 & 12 & 14 & 41 & 26 & 68 & .19 & .16 & 1.4 & 228 \\
\hline 282927081235000 & & 4.7 & 20 & 3.3 & 7.1 & 2.2 & 55 & 13 & 6.4 & $<.1$ & .08 & .15 & 116 \\
\hline 282657080561900 & 36 & 1.3 & 32 & 5.7 & 9.3 & 2.7 & 52 & 86 & 25 & $<.1$ & .3 & 2.9 & 292 \\
\hline 282657080561900 & 24 & 6.3 & 40 & 7 & 58 & 3.3 & 73 & 110 & 26 & $<.1$ & $<5$ & 1.3 & 354 \\
\hline 282702080554200 & & 9.3 & 40 & 18 & 160 & 3.5 & 76 & 290 & 37 & $<.1$ & $<5$ & .24 & 681 \\
\hline 282102081374600 & 48 & 7.2 & 13 & 4.7 & 15 & 5.4 & 25 & 31 & 19 & $<.1$ & .08 & 1.1 & 135 \\
\hline 282452081370200 & 30 & 4.5 & 10 & 6 & 79 & 12 & 25 & 130 & 28 & .12 & .3 & 5.1 & 311 \\
\hline 282450081375100 & & 8.1 & 16 & 9.3 & 39 & 12 & 32 & 64 & 48 & .12 & .13 & .6 & 243 \\
\hline 283019081283100 & 52 & 4.6 & 11 & 3.9 & 16 & 5.3 & 18 & 28 & 27 & .11 & .07 & .4 & 126 \\
\hline 283019081283100 & 66 & 6.7 & 10 & 4.2 & 16 & 5.7 & 11 & 28 & 30 & .11 & .07 & .3 & 124 \\
\hline 283019081283100 & & 6.8 & 12 & 4.6 & 18 & 6.1 & 8.3 & 31 & 39 & .11 & $<5$ & .26 & 148 \\
\hline
\end{tabular}


[All concentrations dissolved, except where noted; DMS, degrees, minutes, seconds; $\mu \mathrm{g} / \mathrm{L}$, micrograms per liter; $\mu \mathrm{S} / \mathrm{cm}$, microsiemens per centimeter; $\mathrm{mg} / \mathrm{L}$, milligrams per liter; ${ }^{\circ} \mathrm{C}$, degrees $\mathrm{Celsius;} \mathrm{CaCO}{ }_{3}$, calcium carbonate; $\mathrm{SO}_{4}$, sulfate; $\mathrm{SiO}_{2}$, silicon dioxide; $\mathrm{N}$, nitrogen, $\mathrm{P}$, phosphorus]

\begin{tabular}{|c|c|c|c|c|c|c|c|c|c|c|c|c|c|}
\hline Site identifier & $\begin{array}{l}\text { Dissolved } \\
\text { solids, } \\
\text { calculated } \\
\text { sum } \\
(\mathrm{mg} / \mathrm{L})\end{array}$ & $\begin{array}{l}\text { Nitrite } \\
\text { (mg/L } \\
\text { as N) }\end{array}$ & $\begin{array}{l}\text { Nitrite } \\
\text { plus } \\
\text { nitrate } \\
\text { (mg/L } \\
\text { as N) }\end{array}$ & $\begin{array}{c}\text { Ammonia } \\
\text { (mg/L } \\
\text { as N) }\end{array}$ & $\begin{array}{c}\text { Organic } \\
\text { plus } \\
\text { ammonia } \\
\text { nitrogen, } \\
\text { whole water } \\
\text { (mg/L as } \mathrm{N} \text { ) }\end{array}$ & $\begin{array}{c}\text { Organic } \\
\text { plus } \\
\text { ammonia } \\
\text { nitrogen } \\
\text { (mg/L as } \mathrm{N})\end{array}$ & $\begin{array}{c}\text { Phos- } \\
\text { phorus, } \\
\text { whole } \\
\text { water } \\
\text { (mg/L } \\
\text { as P) }\end{array}$ & $\begin{array}{c}\text { Phos- } \\
\text { phorus } \\
\text { (mg/L } \\
\text { as P) }\end{array}$ & $\begin{array}{c}\text { Phos- } \\
\text { phorus, } \\
\text { ortho } \\
\text { (mg/L } \\
\text { as P) }\end{array}$ & $\begin{array}{c}\text { Carbon, } \\
\text { organic, } \\
\text { whole } \\
\text { water } \\
(\mathrm{mg} / \mathrm{L})\end{array}$ & $\begin{array}{c}\text { Chloro- } \\
\text { phyll-a } \\
(\mu \mathrm{g} / \mathrm{L})\end{array}$ & $\begin{array}{l}\text { Alumium } \\
(\mu \mathrm{g} / \mathrm{L})\end{array}$ & $\begin{array}{c}\text { Arsenic } \\
(\mu \mathrm{g} / \mathrm{L})\end{array}$ \\
\hline 02237540 & 225 & $<0.01$ & 0.23 & 0.012 & 2.1 & 1.6 & 0.09 & $<0.02$ & 0.02 & 23 & 16 & 110 & 3.7 \\
\hline 02234205 & 113 & $<.01$ & $<.02$ & $<.01$ & .93 & .61 & .02 & $<.02$ & $<.01$ & 7.7 & 25 & & 1.5 \\
\hline 284617081390200 & 252 & $<.01$ & $<.02$ & .02 & 5.1 & 2.2 & .11 & .03 & $<.01$ & 35 & 200 & 35 & 4.2 \\
\hline 02234812 & 93 & $<.01$ & $<.02$ & .02 & .48 & .28 & .02 & $<.02$ & $<.01$ & 7 & & 44 & 2.3 \\
\hline 02234812 & 86 & $<.01$ & $<.02$ & .05 & .8 & .56 & $<.02$ & $<.02$ & .01 & 20 & 7.3 & 29 & 2.4 \\
\hline 02234812 & 94 & $<.01$ & $<.02$ & $<.01$ & .56 & .47 & $<.02$ & $<.02$ & $<.01$ & 7.2 & 2.8 & 42 & 2.2 \\
\hline 02262200 & 44 & $<.01$ & .12 & $<.01$ & 1.1 & .81 & .02 & $<.02$ & .01 & 22 & 5.1 & 280 & $<2$ \\
\hline 02262200 & 47 & $<.01$ & .09 & .029 & 1.3 & 1.4 & .03 & $<.02$ & $<.01$ & 22 & 4.2 & 300 & .7 \\
\hline 02262200 & 60 & $<.01$ & .12 & $<.01$ & 1.2 & .95 & $<.02$ & $<.02$ & .01 & 17 & 3 & 190 & .6 \\
\hline 02266275 & 87 & $<.01$ & $<.02$ & $<.01$ & .77 & .59 & $<.02$ & $<.02$ & $<.01$ & 11 & $<.1$ & 26 & $<2$ \\
\hline 02266275 & 105 & $<.01$ & $<.02$ & $<.01$ & .62 & .56 & $<.02$ & $<.02$ & $<.01$ & 11 & 1.7 & 36 & 1.1 \\
\hline 02234297 & 162 & $<.01$ & $<.02$ & $<.01$ & .62 & .52 & .02 & $<.02$ & $<.01$ & 8.5 & 2.8 & 32 & $<2$ \\
\hline 02234297 & 170 & $<.01$ & .05 & .06 & .97 & .54 & .03 & $<.02$ & $<.01$ & 13 & 6 & 42 & $<1$ \\
\hline 02234225 & 112 & $<.01$ & $<.02$ & .05 & .97 & .6 & .03 & $<.02$ & .02 & 7.3 & 14 & 26 & $<1$ \\
\hline 284000081275000 & 109 & $<.01$ & $<.02$ & .021 & .72 & .55 & $<.02$ & $<.02$ & $<.01$ & 8.5 & 5.6 & & 1.8 \\
\hline 283305081304200 & 115 & $<.01$ & $<.02$ & .02 & 1.1 & .64 & .05 & $<.02$ & $<.01$ & 14 & & 5.1 & 1.2 \\
\hline 283528081055300 & 73 & $<.01$ & $<.02$ & $<.01$ & .81 & .51 & .04 & $<.02$ & .01 & 15 & 5.4 & 96 & $<2$ \\
\hline 283528081055300 & 76 & $<.01$ & $<.02$ & .04 & .82 & .7 & .02 & $<.02$ & $<.01$ & 17 & 3.5 & 65 & $<1$ \\
\hline 283528081055300 & 90 & $<.01$ & $<.02$ & $<.01$ & .91 & .59 & $<.02$ & $<.02$ & .01 & 12 & 8 & 62 & .8 \\
\hline 02234300 & 123 & $<.01$ & $<.02$ & $<.01$ & .63 & .44 & $<.02$ & $<.02$ & .01 & 6.4 & 6.9 & 32 & 2.6 \\
\hline 02261900 & 49 & $<.01$ & $<.02$ & .027 & 1.5 & 1.3 & .03 & $<.02$ & $<.01$ & 25 & 5.9 & 290 & .9 \\
\hline 02237745 & 159 & $<.01$ & $<.02$ & .01 & .74 & .64 & $<.02$ & $<.02$ & $<.01$ & 7.8 & 12 & 19 & $<2$ \\
\hline 02237745 & 164 & $<.01$ & $<.02$ & .04 & .93 & .79 & $<.02$ & $<.02$ & $<.01$ & 12 & 5.8 & 11 & 1.8 \\
\hline 02237745 & 174 & $<.01$ & $<.02$ & $<.01$ & .68 & .58 & $<.02$ & $<.02$ & $<.01$ & 6.8 & 10 & 19 & 1.7 \\
\hline 282210081385100 & 29 & $<.01$ & .02 & .04 & .45 & .35 & $<.02$ & $<.02$ & $<.01$ & 12 & & 58 & $<1$ \\
\hline 283219081201302 & 94 & $<.01$ & $<.02$ & $<.01$ & 1.3 & .57 & $<.02$ & $<.02$ & .01 & 8.3 & 34 & 42 & .6 \\
\hline 284034081315700 & 183 & $<.01$ & $<.02$ & $<.01$ & 5.5 & 1.4 & .14 & $<.02$ & $<.01$ & 22 & 180 & & 5.5 \\
\hline 282927081235000 & 85 & $<.01$ & $<.02$ & $<.01$ & 1 & .84 & .03 & $<.02$ & $<.01$ & .9 & 7.5 & 59 & 1.5 \\
\hline 282657080561900 & 194 & $<.01$ & $<.02$ & .07 & .84 & .78 & $<.02$ & $<.02$ & .03 & 20 & $<.1$ & 31 & $<1$ \\
\hline 282657080561900 & 290 & $<.01$ & $<.02$ & $<.01$ & 1.5 & 1 & .08 & .02 & .02 & 19 & 32 & $<3$ & .9 \\
\hline 282702080554200 & 596 & $<.01$ & $<.02$ & $<.01$ & 1.2 & 1.1 & $<.02$ & $<.02$ & $<.01$ & 14 & 6.6 & 10 & 1.3 \\
\hline 282102081374600 & 104 & $<.01$ & $<.02$ & $<.01$ & .84 & .62 & .02 & $<.02$ & $<.01$ & 9 & 5.2 & 100 & 3 \\
\hline 282452081370200 & 286 & $<.01$ & $<.02$ & $<.01$ & .83 & .62 & .03 & $<.02$ & $<.01$ & 11 & 6.8 & 32 & 3.6 \\
\hline 282450081375100 & 209 & $<.01$ & $<.02$ & .044 & 1.5 & .98 & .04 & $<.02$ & $<.01$ & 21 & 18 & 12 & .7 \\
\hline 283019081283100 & 98 & $<.01$ & $<.02$ & .02 & .64 & .47 & .03 & $<.02$ & $<.01$ & 11 & 24 & 41 & $<2$ \\
\hline 283019081283100 & 100 & $<.01$ & $<.02$ & .04 & 1 & .83 & .02 & $<.02$ & $<.01$ & 12 & 3.4 & 38 & 1.1 \\
\hline 283019081283100 & 116 & $<.01$ & $<.02$ & $<.01$ & .7 & .6 & .03 & $<.02$ & $<.01$ & 11 & 3.1 & 32 & 1.2 \\
\hline
\end{tabular}


Appendix D. Field measurements and concentrations of major ions, nutrients, and trace elements in samples collected from lakes during this study, 2000-2001. (Continued)

[All concentrations dissolved, except where noted; DMS, degrees, minutes, seconds; $\mu \mathrm{g} / \mathrm{L}$, micrograms per liter; $\mu \mathrm{S} / \mathrm{cm}$, microsiemens per centimeter; $\mathrm{mg} / \mathrm{L}$, milligrams per liter; ${ }^{\circ} \mathrm{C}$, degrees $\mathrm{Celsius;} \mathrm{CaCO}{ }_{3}$, calcium carbonate; $\mathrm{SO}_{4}$, sulfate; $\mathrm{SiO}_{2}$, silicon dioxide; $\mathrm{N}$, nitrogen, $\mathrm{P}$, phosphorus]

\begin{tabular}{|c|c|c|c|c|c|c|c|c|c|c|c|c|c|}
\hline Site identifier & $\begin{array}{c}\text { Barium } \\
(\mu \mathrm{g} / \mathrm{L})\end{array}$ & $\begin{array}{c}\text { Beryllium } \\
(\mu \mathrm{g} / \mathrm{L})\end{array}$ & $\begin{array}{l}\text { Boron } \\
(\mu \mathrm{g} / \mathrm{L})\end{array}$ & $\begin{array}{c}\text { Cadmium } \\
(\mu \mathrm{g} / \mathrm{L})\end{array}$ & $\begin{array}{l}\text { Chromium } \\
(\mu \mathrm{g} / \mathrm{L})\end{array}$ & $\begin{array}{c}\text { Cobalt } \\
(\mu \mathrm{g} / \mathrm{L})\end{array}$ & $\begin{array}{l}\text { Iron } \\
(\mu \mathrm{g} / \mathrm{L})\end{array}$ & $\begin{array}{l}\text { Lead } \\
(\mu \mathrm{g} / \mathrm{L})\end{array}$ & $\begin{array}{c}\text { Lithium } \\
(\mu \mathrm{g} / \mathrm{L})\end{array}$ & $\begin{array}{c}\text { Manganese } \\
(\mu \mathrm{g} / \mathrm{L})\end{array}$ & $\begin{array}{c}\text { Selenium } \\
(\mu \mathrm{g} / \mathrm{L})\end{array}$ & $\begin{array}{c}\text { Strontium } \\
(\mu \mathrm{g} / \mathrm{L})\end{array}$ & $\begin{array}{c}\text { Vanadium } \\
(\mu \mathrm{g} / \mathrm{L})\end{array}$ \\
\hline 02237540 & 20 & $<1$ & 86 & $<0.5$ & $<1$ & $<1$ & 34 & $<2$ & $<1$ & 6.4 & 1.6 & 65 & 2 \\
\hline 02234205 & & & & & & & $<2$ & & & $<1$ & $<.5$ & 64 & \\
\hline 284617081390200 & $<.5$ & $<1$ & 41 & $<.5$ & $<1$ & $<1$ & $<2$ & $<2$ & 1.8 & 1.3 & $<1$ & 170 & 2 \\
\hline 02234812 & 3 & $<.5$ & 49 & $<.5$ & $<1$ & $<1$ & 1.2 & $<1$ & $<.5$ & .3 & $<2$ & 61 & 2 \\
\hline 02234812 & 3 & $<1$ & 52 & $<.5$ & $<1$ & $<1$ & $<2$ & $<2$ & $<1$ & $<1$ & $<4$ & 57 & 1 \\
\hline 02234812 & 5 & $<1$ & 50 & $<.5$ & $<1$ & $<1$ & 2.2 & $<2$ & $<1$ & $<1$ & $<.5$ & 60 & 1 \\
\hline 02262200 & 15 & $<.5$ & 30 & $<.5$ & $<1$ & $<1$ & 405 & $<1$ & .6 & 7.8 & $<2$ & 31 & $<1$ \\
\hline 02262200 & 14 & $<1$ & 30 & $<.5$ & $<1$ & $<1$ & 540 & $<2$ & $<1$ & 7.2 & .5 & 31 & $<1$ \\
\hline 02262200 & 16 & $<1$ & 40 & $<.5$ & $<1$ & $<1$ & 417 & $<2$ & $<1$ & 5.7 & $<.5$ & 36 & $<1$ \\
\hline 02266275 & 10 & $<.5$ & 49 & $<.5$ & $<1$ & $<1$ & 2.2 & $<1$ & $<.5$ & $<.2$ & $<2$ & 25 & 1 \\
\hline 02266275 & 10 & $<1$ & 60 & $<.5$ & $<1$ & $<1$ & 2.3 & $<2$ & $<1$ & $<1$ & $<.5$ & 28 & $<1$ \\
\hline 02234297 & 9 & $<.5$ & 110 & $<.5$ & $<1$ & $<1$ & 3.6 & $<1$ & $<.5$ & 3.2 & $<2$ & 44 & 2 \\
\hline 02234297 & 9 & $<1$ & 110 & $<.5$ & $<1$ & $<1$ & 3.5 & $<2$ & $<1$ & 7.5 & $<4$ & 43 & 3 \\
\hline 02234225 & .5 & $<1$ & 33 & $<.5$ & $<1$ & $<1$ & $<2$ & $<2$ & 1.1 & $<1$ & $<4$ & 67 & 2 \\
\hline 284000081275000 & & & & & & & 2.3 & & & 2.1 & $<.5$ & 58 & \\
\hline 283305081304200 & 17 & $<1$ & 40 & $<.5$ & $<1$ & $<1$ & 10 & $<2$ & $<1$ & 1.1 & $<4$ & 59 & $<1$ \\
\hline 283528081055300 & 13 & $<.5$ & 38 & $<.5$ & $<1$ & $<1$ & 154 & $<1$ & $<.5$ & 3.5 & $<2$ & 35 & 1 \\
\hline 283528081055300 & 12 & $<1$ & 40 & $<.5$ & $<1$ & $<1$ & 42 & $<2$ & $<1$ & 2.1 & $<4$ & 33 & 1 \\
\hline 283528081055300 & 14 & $<1$ & 50 & $<.5$ & $<1$ & $<1$ & 67 & $<2$ & $<1$ & 3.6 & $<.5$ & 37 & 2 \\
\hline 02234300 & 9 & $<1$ & 40 & $<.5$ & $<1$ & $<1$ & 2 & $<2$ & $<1$ & $<1$ & $<.5$ & 52 & 2 \\
\hline 02261900 & 15 & $<1$ & 30 & $<.5$ & $<1$ & $<1$ & 835 & $<2$ & $<1$ & 6.6 & $<.5$ & 32 & $<1$ \\
\hline 02237745 & 40 & $<.5$ & 61 & $<.5$ & $<1$ & $<1$ & 2.7 & $<1$ & $<.5$ & .7 & $<2$ & 76 & 1 \\
\hline 02237745 & 43 & $<1$ & 62 & $<.5$ & $<1$ & $<1$ & 3.6 & $<2$ & $<1$ & $<1$ & $<4$ & 75 & 1 \\
\hline 02237745 & 43 & $<1$ & 60 & $<.5$ & $<1$ & $<1$ & 3.4 & $<2$ & $<1$ & $<1$ & $<.5$ & 81 & $<1$ \\
\hline 282210081385100 & 3 & $<1$ & 25 & $<.5$ & $<1$ & $<1$ & 150 & $<2$ & $<1$ & 15 & $<4$ & 9 & $<1$ \\
\hline 283219081201302 & $<.5$ & $<1$ & 30 & $<.5$ & $<1$ & $<1$ & $<2$ & $<2$ & $<1$ & $<1$ & $<.5$ & 56 & 2 \\
\hline 284034081315700 & & & & & & & $<2$ & & & $<1$ & .7 & 110 & \\
\hline 282927081235000 & 2 & $<1$ & 27 & $<.5$ & $<1$ & $<1$ & 3.3 & $<2$ & $<1$ & 1.6 & .5 & 55 & 1 \\
\hline 282657080561900 & 21 & $<1$ & 25 & $<.5$ & $<1$ & $<1$ & 95 & $<2$ & 1.1 & 2.5 & $<4$ & 450 & $<1$ \\
\hline 282657080561900 & 20 & $<1$ & 30 & $<.5$ & $<1$ & $<1$ & 38 & $<2$ & 1 & 5.7 & .8 & 550 & $<1$ \\
\hline 282702080554200 & 56 & $<1$ & 40 & $<.5$ & $<1$ & $<1$ & 8 & $<2$ & 3 & $<1$ & 1.6 & 1,600 & $<1$ \\
\hline 282102081374600 & 3 & $<1$ & 55 & $<.5$ & $<1$ & $<1$ & 4.7 & $<2$ & $<1$ & $<1$ & .5 & 33 & 6 \\
\hline 282452081370200 & 11 & $<1$ & 200 & $<.5$ & $<1$ & $<1$ & 66 & $<2$ & $<1$ & 1.2 & 1.6 & 40 & 1 \\
\hline 282450081375100 & 15 & $<1$ & 120 & $<.5$ & $<1$ & $<1$ & 8.2 & $<2$ & $<1$ & 2.8 & $<.5$ & 82 & $<1$ \\
\hline 283019081283100 & 13 & $<.5$ & 61 & $<.5$ & $<1$ & $<1$ & 11 & $<1$ & $<.5$ & 1.1 & $<2$ & 60 & 2 \\
\hline 283019081283100 & 12 & $<1$ & 60 & $<.5$ & $<1$ & $<1$ & 9.2 & $<2$ & $<1$ & 1.2 & $<.5$ & 57 & 1 \\
\hline 283019081283100 & 16 & $<1$ & 70 & $<.5$ & $<1$ & $<1$ & 12 & $<2$ & $<1$ & 3.3 & $<.5$ & 64 & 2 \\
\hline
\end{tabular}


Appendix E. Concentrations of pesticides in samples collected from lakes and streams during this study, 2000-2001.

[All concentrations dissolved; $\mu \mathrm{g} / \mathrm{L}$, micrograms per liter; <, less than; $\mathrm{E}$, estimated concentration; $\mathrm{M}$, presence verified, not quantified]

\begin{tabular}{|c|c|c|c|c|c|c|c|c|c|c|c|}
\hline Site identifier & Site name & $\begin{array}{l}\text { Map } \\
\text { No. }\end{array}$ & Date & $\begin{array}{l}\text { 2,6-Diethy- } \\
\text { laniline } \\
(\mu \mathrm{g} / \mathrm{L})\end{array}$ & $\begin{array}{c}\text { Actochlor } \\
(\mu \mathrm{g} / \mathrm{L})\end{array}$ & $\begin{array}{c}\text { Alachlor } \\
(\mu \mathrm{g} / \mathrm{L})\end{array}$ & $\begin{array}{l}\text { alpha } \\
\mathrm{HCH}\end{array}$ & $\begin{array}{c}\text { Atrazine } \\
(\mu \mathrm{g} / \mathrm{L})\end{array}$ & $\begin{array}{l}\text { Benfluralin } \\
(\mu \mathrm{g} / \mathrm{L})\end{array}$ & $\begin{array}{c}\text { Butylate } \\
(\mu \mathrm{g} / \mathrm{L})\end{array}$ & $\begin{array}{c}\text { Carbaryl } \\
(\mu \mathrm{g} / \mathrm{L})\end{array}$ \\
\hline \multicolumn{12}{|l|}{ Lakes } \\
\hline 02234205 & Lake Adair at Orlando & 2 & $5 / 29 / 2001$ & $<0.002$ & $<0.004$ & $<0.002$ & $<0.005$ & 0.375 & $<0.010$ & $<0.002$ & $<0.041$ \\
\hline 02234812 & Lake Fairview at Orlando & 4 & $7 / 12 / 2000$ & $<.003$ & $<.002$ & $<.002$ & $<.002$ & .155 & $<.002$ & $<.002$ & $<.003$ \\
\hline 02234812 & Lake Fairview at Orlando & & $11 / 6 / 2000$ & $<.002$ & $<.004$ & $<.002$ & $<.005$ & .116 & $<.010$ & $<.002$ & $<.041$ \\
\hline 02234812 & Lake Fairview at Orlando & & $4 / 23 / 2001$ & $<.002$ & $<.004$ & $<.002$ & $<.005$ & .11 & $<.010$ & $<.002$ & $<.041$ \\
\hline 02262200 & Lake Hart near Narcoossee & 5 & $7 / 20 / 2000$ & $<.003$ & $<.002$ & $<.002$ & $<.002$ & $<.001$ & $<.002$ & $<.002$ & $<.003$ \\
\hline 02262200 & Lake Hart near Narcoossee & & $10 / 30 / 2000$ & $<.002$ & $<.004$ & $<.002$ & $<.005$ & .01 & $<.010$ & $<.002$ & $<.041$ \\
\hline 02262200 & Lake Hart near Narcoossee & & $5 / 8 / 2001$ & $<.002$ & $<.004$ & $<.002$ & $<.005$ & .013 & $<.010$ & $<.002$ & $<.041$ \\
\hline 02266275 & Hickorynut Lake near Oakland & 6 & $7 / 18 / 2000$ & $<.003$ & $<.002$ & $<.002$ & $<.002$ & .008 & $<.002$ & $<.002$ & $<.003$ \\
\hline 02266275 & Hickorynut Lake near Oakland & & $4 / 26 / 2001$ & $<.002$ & $<.004$ & $<.002$ & $<.005$ & .009 & $<.010$ & $<.002$ & $<.041$ \\
\hline 02234297 & Lake Hope at Maitland & 7 & $7 / 19 / 2000$ & $<.003$ & $<.002$ & $<.002$ & $<.002$ & .039 & $<.002$ & $<.002$ & $<.003$ \\
\hline 02234297 & Lake Hope at Maitland & & $11 / 1 / 2000$ & $<.002$ & $<.004$ & $<.002$ & $<.005$ & .037 & $<.010$ & $<.002$ & $<.041$ \\
\hline 284000081275000 & Lake Jackson near Apopka & 9 & $5 / 30 / 2001$ & $<.002$ & $<.004$ & $<.002$ & $<.005$ & .013 & $<.010$ & $<.002$ & $<.041$ \\
\hline 283528081055300 & Lake Louise near Bithlo & 11 & $7 / 19 / 2000$ & $<.003$ & $<.002$ & $<.002$ & $<.002$ & .005 & $<.002$ & $<.002$ & E.014 \\
\hline 283528081055300 & Lake Louise near Bithlo & & $11 / 1 / 2000$ & $<.002$ & $<.004$ & $<.002$ & $<.005$ & E.003 & $<.010$ & $<.002$ & E.023 \\
\hline 283528081055300 & Lake Louise near Bithlo & & $5 / 7 / 2001$ & $<.002$ & $<.004$ & $<.002$ & $<.005$ & E.006 & $<.010$ & $<.002$ & $<.041$ \\
\hline 02237745 & Lake Ola at Tangerine & 14 & $7 / 18 / 2000$ & $<.003$ & $<.002$ & $<.002$ & $<.002$ & .03 & $<.002$ & $<.002$ & $<.003$ \\
\hline 02237745 & Lake Ola at Tangerine & & $11 / 2 / 2000$ & $<.002$ & $<.004$ & $<.002$ & $<.005$ & .016 & $<.010$ & $<.002$ & $<.041$ \\
\hline 02237745 & Lake Ola at Tangerine & & $4 / 23 / 2001$ & $<.002$ & $<.004$ & $<.002$ & $<.005$ & .02 & $<.010$ & $<.002$ & $<.041$ \\
\hline 284034081315700 & Marshall Lake near Apopka & 17 & $5 / 30 / 2001$ & $<.002$ & $<.004$ & $<.002$ & $<.005$ & E.007 & $<.010$ & $<.002$ & $<.041$ \\
\hline 282927081235000 & Lake Ellenore near Pine Castle & 18 & $5 / 21 / 2001$ & $<.002$ & $<.004$ & $<.002$ & $<.005$ & .051 & $<.010$ & $<.002$ & $<.041$ \\
\hline 282657080561900 & Pond at Tosohatchee State Reserve & 19 & $11 / 8 / 2000$ & $<.002$ & $<.004$ & $<.002$ & $<.005$ & E.003 & $<.010$ & $<.002$ & $<.041$ \\
\hline 282657080561900 & Pond at Tosohatchee State Reserve & & $4 / 24 / 2001$ & $<.002$ & $<.004$ & $<.002$ & $<.005$ & E.007 & $<.010$ & $<.002$ & $<.041$ \\
\hline 282102081374600 & Raccoon Lake near Windermere & 21 & $5 / 24 / 2001$ & $<.002$ & $<.004$ & $<.002$ & $<.005$ & .011 & $<.010$ & $<.002$ & $<.041$ \\
\hline 283019081283100 & Turkey Lake at Orlando & 24 & 7/13/2000 & $<.003$ & $<.002$ & $<.002$ & $<.002$ & .023 & $<.002$ & $<.002$ & $<.003$ \\
\hline 283019081283100 & Turkey Lake at Orlando & & $10 / 31 / 2000$ & $<.002$ & $<.004$ & $<.002$ & $<.005$ & .017 & $<.010$ & $<.002$ & $<.041$ \\
\hline 283019081283100 & Turkey Lake at Orlando & & $4 / 26 / 2001$ & $<.002$ & $<.004$ & $<.002$ & $<.005$ & .044 & $<.010$ & $<.002$ & E.004 \\
\hline \multicolumn{12}{|l|}{ Streams } \\
\hline 02262900 & Boggy Creek near Taft & & $4 / 26 / 2000$ & $<.003$ & $<.002$ & $<.002$ & $<.002$ & .044 & $<.002$ & $<.002$ & $<.003$ \\
\hline 02262900 & Boggy Creek near Taft & & $9 / 6 / 2000$ & $<.003$ & $<.002$ & $<.002$ & $<.002$ & E.003 & $<.002$ & $<.002$ & E.004 \\
\hline 02262900 & Boggy Creek near Taft & & $2 / 22 / 2001$ & $<.002$ & $<.004$ & $<.002$ & $<.005$ & E.002 & $<.010$ & $<.002$ & $<.041$ \\
\hline 02233500 & Econlockhatchee River & & $4 / 12 / 2000$ & $<.003$ & $<.002$ & $<.002$ & $<.002$ & .366 & $<.002$ & $<.002$ & E.011 \\
\hline 02233500 & Econlockhatchee River & & $9 / 5 / 2000$ & $<.003$ & $<.002$ & $<.002$ & $<.002$ & .078 & $<.002$ & $<.002$ & E.008 \\
\hline 02233500 & Econlockhatchee River & & $2 / 6 / 2001$ & $<.002$ & $<.004$ & $<.002$ & $<.005$ & .195 & $<.010$ & $<.002$ & $<.041$ \\
\hline 02233200 & Little Econlockhatchee River & & $4 / 25 / 2000$ & $<.003$ & $<.002$ & $<.002$ & $<.002$ & .124 & $<.002$ & $<.002$ & $<.003$ \\
\hline 02233200 & Little Econlockhatchee River & & $8 / 31 / 2000$ & $<.003$ & $<.002$ & $<.002$ & $<.002$ & .106 & $<.002$ & $<.002$ & E.007 \\
\hline 02233200 & Little Econlockhatchee River & & $2 / 8 / 2001$ & $<.002$ & $<.004$ & $<.002$ & $<.005$ & .168 & $<.010$ & $<.002$ & $<.041$ \\
\hline 02234990 & Little Wekiva River near Altamonte Springs & & $4 / 11 / 2000$ & $<.003$ & $<.002$ & $<.002$ & $<.002$ & .716 & $<.002$ & $<.002$ & E.022 \\
\hline 02234990 & Little Wekiva River near Altamonte Springs & & $8 / 29 / 2000$ & $<.003$ & $<.002$ & $<.002$ & $<.002$ & .048 & $<.002$ & $<.002$ & E.014 \\
\hline 02234990 & Little Wekiva River near Altamonte Springs & & $2 / 14 / 2001$ & $<.002$ & $<.004$ & $<.002$ & $<.005$ & .373 & $<.010$ & $<.002$ & $\mathrm{E}<.041$ \\
\hline 02263800 & Shingle Creek at airport near Kissimmee & & $4 / 24 / 2000$ & $<.003$ & $<.002$ & $<.002$ & $<.002$ & .373 & $<.002$ & $<.002$ & $<.003$ \\
\hline 02263800 & Shingle Creek at airport near Kissimmee & & $9 / 13 / 2000$ & $<.003$ & $<.002$ & $<.002$ & $<.002$ & .04 & $<.002$ & $<.002$ & $<.003$ \\
\hline 02263800 & Shingle Creek at airport near Kissimmee & & $2 / 28 / 2001$ & $<.002$ & $<.004$ & $<.002$ & $<.005$ & .179 & $<.010$ & $<.002$ & $<.041$ \\
\hline 02234635 & Wekiva River near Apopka & & $4 / 12 / 2000$ & $<.003$ & $<.002$ & $<.002$ & $<.002$ & .008 & $<.002$ & $<.002$ & $<.003$ \\
\hline 02234635 & Wekiva River near Apopka & & $9 / 6 / 2000$ & $<.003$ & $<.002$ & $<.002$ & $<.002$ & .005 & $<.002$ & $\mathrm{E}<.002$ & $<.003$ \\
\hline 02234635 & Wekiva River near Apopka & & $2 / 5 / 2001$ & $<.002$ & $<.004$ & $<.002$ & $<.005$ & $<.007$ & $<.010$ & $<.002$ & $<.041$ \\
\hline
\end{tabular}


Appendix E. Concentrations of pesticides in samples collected from lakes and streams during this study, 2000-2001. (Continued) [All concentrations dissolved; $\mu \mathrm{g} / \mathrm{L}$, micrograms per liter; <, less than; $\mathrm{E}$, estimated concentration; $\mathrm{M}$, presence verified, not quantified]

\begin{tabular}{|c|c|c|c|c|c|c|c|c|c|c|c|c|c|}
\hline Site identifier & $\begin{array}{c}\text { Carbofran } \\
(\mu \mathrm{g} / \mathrm{L})\end{array}$ & $\begin{array}{c}\text { Chlorpyrifos } \\
(\mu \mathrm{g} / \mathrm{L})\end{array}$ & $\begin{array}{c}\text { CIAT } \\
(\mu \mathrm{g} / \mathrm{L})\end{array}$ & $\begin{array}{c}\text { Cyanaine } \\
(\mu \mathrm{g} / \mathrm{L})\end{array}$ & $\begin{array}{l}\text { DCPA } \\
(\mu \mathrm{g} / \mathrm{L})\end{array}$ & $\begin{array}{l}\text { Diazinon } \\
(\mu \mathrm{g} / \mathrm{L})\end{array}$ & $\begin{array}{c}\text { Dieldrin } \\
(\mu \mathrm{g} / \mathrm{L})\end{array}$ & $\begin{array}{l}\text { Disulfoton } \\
(\mu \mathrm{g} / \mathrm{L})\end{array}$ & $\begin{array}{l}\text { EPTC } \\
\text { ( } \mu \mathrm{g} / \mathrm{L})\end{array}$ & $\begin{array}{c}\text { Ethal- } \\
\text { fluralin } \\
(\mu \mathrm{g} / L)\end{array}$ & $\begin{array}{c}\text { Etho- } \\
\text { prophos } \\
(\mu \mathrm{g} / \mathrm{L})\end{array}$ & $\begin{array}{c}\text { Fonofos } \\
\text { ( } \mu \mathrm{g} / \mathrm{L})\end{array}$ & $\begin{array}{c}\text { Lindane } \\
(\mu \mathrm{g} / \mathrm{L})\end{array}$ \\
\hline \multicolumn{14}{|l|}{ Lakes } \\
\hline 02234205 & $<0.020$ & $<0.005$ & E0.032 & $<0.018$ & $<0.003$ & 0.026 & $<0.005$ & $<0.02$ & $<0.002$ & $<0.009$ & $<0.005$ & $<0.003$ & $<0.004$ \\
\hline 02234812 & $<.003$ & $<.004$ & E.038 & $<.004$ & $<.002$ & .008 & $<.001$ & $<.02$ & $<.002$ & $<.004$ & $<.003$ & $<.003$ & $<.004$ \\
\hline 02234812 & $<.020$ & $<.005$ & E.031 & $<.018$ & $<.003$ & .008 & $<.005$ & $<.02$ & $<.002$ & $<.009$ & $<.005$ & $<.003$ & $<.004$ \\
\hline 02234812 & $<.020$ & $<.005$ & E.024 & $<.018$ & $<.003$ & E.005 & $<.005$ & $<.02$ & $<.002$ & $<.009$ & $<.005$ & $<.003$ & $<.004$ \\
\hline 02262200 & $<.003$ & $<.004$ & $<.002$ & $<.004$ & $<.002$ & $<.002$ & $<.001$ & $<.02$ & $<.002$ & $<.004$ & $<.003$ & $<.003$ & $<.004$ \\
\hline 02262200 & $<.020$ & $<.005$ & $<.006$ & $<.018$ & $<.003$ & $<.005$ & $<.005$ & $<.02$ & $<.002$ & $<.009$ & $<.005$ & $<.003$ & $<.004$ \\
\hline 02262200 & $<.020$ & $<.005$ & E.003 & $<.018$ & $<.003$ & $<.005$ & $<.005$ & $<.02$ & $<.002$ & $<.009$ & $<.005$ & $<.003$ & $<.004$ \\
\hline 02266275 & $<.003$ & $<.004$ & $<.002$ & $<.004$ & $<.002$ & $<.002$ & $<.001$ & $<.02$ & $<.002$ & $<.004$ & $<.003$ & $<.003$ & $<.004$ \\
\hline 02266275 & $<.020$ & $<.005$ & E.003 & $<.018$ & $<.003$ & E.005 & $<.005$ & $<.02$ & $<.002$ & $<.009$ & $<.005$ & $<.003$ & $<.004$ \\
\hline 02234297 & $<.003$ & $<.004$ & E.005 & $<.004$ & $<.002$ & .012 & $<.001$ & $<.02$ & $<.002$ & $<.004$ & $<.003$ & $<.003$ & $<.004$ \\
\hline 02234297 & $<.020$ & $<.005$ & E.005 & $<.018$ & $<.003$ & E.005 & $<.005$ & $<.02$ & $<.002$ & $<.009$ & $<.005$ & $<.003$ & $<.004$ \\
\hline 284000081275000 & $<.020$ & $<.005$ & $<.006$ & $<.018$ & $<.003$ & .011 & $<.005$ & $<.02$ & $<.002$ & $<.009$ & $<.005$ & $<.003$ & $<.004$ \\
\hline 283528081055300 & $<.003$ & $<.004$ & $<.002$ & $<.004$ & $<.002$ & $<.002$ & $<.001$ & $<.02$ & $<.002$ & $<.004$ & $<.003$ & $<.003$ & $<.004$ \\
\hline 283528081055300 & $<.020$ & $<.005$ & E.004 & $<.018$ & $<.003$ & $<.005$ & $<.005$ & $<.02$ & $<.002$ & $<.009$ & $<.005$ & $<.003$ & $<.004$ \\
\hline 283528081055300 & $<.020$ & $<.005$ & $<.006$ & $<.018$ & $<.003$ & $<.005$ & $<.005$ & $<.02$ & $<.002$ & $<.009$ & $<.005$ & $<.003$ & $<.004$ \\
\hline 02237745 & $<.003$ & $<.004$ & E.009 & $<.004$ & $<.002$ & E.003 & $<.001$ & $<.02$ & $<.002$ & $<.004$ & $<.003$ & $<.003$ & $<.004$ \\
\hline 02237745 & $<.020$ & $<.005$ & E.008 & $<.018$ & $<.003$ & $<.005$ & $<.005$ & $<.02$ & $<.002$ & $<.009$ & $<.005$ & $<.003$ & $<.004$ \\
\hline 02237745 & $<.020$ & $<.005$ & E.005 & $<.018$ & $<.003$ & $<.005$ & $<.005$ & $<.02$ & $<.002$ & $<.009$ & $<.005$ & $<.003$ & $<.004$ \\
\hline 284034081315700 & $<.020$ & $<.005$ & $<.006$ & $<.018$ & $<.003$ & $<.005$ & $<.005$ & $<.02$ & $<.002$ & $<.009$ & $<.005$ & $<.003$ & $<.004$ \\
\hline 282927081235000 & $<.020$ & $<.005$ & E.008 & $<.018$ & $<.003$ & .01 & $<.005$ & $<.02$ & $<.002$ & $<.009$ & $<.005$ & $<.003$ & $<.004$ \\
\hline 282657080561900 & $<.020$ & $<.005$ & $<.006$ & $<.018$ & $<.003$ & $<.005$ & $<.005$ & $<.02$ & $<.002$ & $<.009$ & $<.005$ & $<.003$ & $<.004$ \\
\hline 282657080561900 & $<.020$ & $<.005$ & E.002 & $<.018$ & $<.003$ & $<.005$ & $<.005$ & $<.02$ & $<.002$ & $<.009$ & $<.005$ & $<.003$ & $<.004$ \\
\hline 282102081374600 & $<.020$ & E.003 & $<.006$ & $<.018$ & $<.003$ & .005 & $<.005$ & $<.02$ & $<.002$ & $<.009$ & $<.005$ & $<.003$ & $<.004$ \\
\hline 283019081283100 & $<.003$ & $<.004$ & E.004 & $<.004$ & $<.002$ & E.002 & $<.001$ & $<.02$ & $<.002$ & $<.004$ & $<.003$ & $<.003$ & $<.004$ \\
\hline 283019081283100 & $<.020$ & $<.005$ & E.005 & $<.018$ & $<.003$ & E.004 & $<.005$ & $<.02$ & $<.002$ & $<.009$ & $<.005$ & $<.003$ & $<.004$ \\
\hline 283019081283100 & $<.020$ & $<.005$ & E.006 & $<.018$ & $<.003$ & .008 & $<.005$ & $<.02$ & $<.002$ & $<.009$ & $<.005$ & $<.003$ & $<.004$ \\
\hline \multicolumn{14}{|l|}{ Streams } \\
\hline 02262900 & $<.003$ & $<.004$ & E.007 & $<.004$ & $<.002$ & $<.002$ & $<.001$ & $<.02$ & $<.002$ & $<.004$ & $<.003$ & $<.003$ & $<.004$ \\
\hline 02262900 & $<.003$ & $<.004$ & $<.002$ & $<.004$ & $<.002$ & $<.002$ & $<.001$ & $<.02$ & $<.002$ & $<.004$ & $<.003$ & $<.003$ & $<.004$ \\
\hline 02262900 & $<.020$ & $<.005$ & $<.006$ & $<.018$ & $<.003$ & $<.005$ & $<.005$ & $<.02$ & $<.002$ & $<.009$ & $<.005$ & $<.003$ & $<.004$ \\
\hline 02233500 & $<.003$ & $<.004$ & E.024 & $<.004$ & $<.002$ & .007 & $<.001$ & $<.02$ & $<.002$ & $<.004$ & $<.003$ & $<.003$ & $<.009$ \\
\hline 02233500 & $<.003$ & $<.004$ & E.011 & $<.004$ & $<.002$ & .01 & $<.001$ & $<.02$ & $<.002$ & $<.004$ & $<.003$ & $<.003$ & $<.004$ \\
\hline 02233500 & $<.020$ & $<.005$ & E.018 & $<.018$ & $<.003$ & E.005 & $<.005$ & $<.02$ & $<.002$ & $<.009$ & $<.005$ & $<.003$ & $<.004$ \\
\hline 02233200 & $<.003$ & $<.004$ & E.018 & $<.004$ & $<.002$ & .009 & $<.001$ & $<.02$ & $<.002$ & $<.004$ & $<.003$ & $<.003$ & $<.004$ \\
\hline 02233200 & $<.003$ & E.002 & E.015 & $<.004$ & $<.002$ & .04 & $<.001$ & $<.02$ & $<.002$ & $<.004$ & $<.003$ & $<.003$ & $<.004$ \\
\hline 02233200 & $<.020$ & $<.005$ & E.016 & $<.018$ & $<.003$ & .009 & $<.005$ & $<.02$ & $<.002$ & $<.009$ & $<.005$ & $<.003$ & $<.004$ \\
\hline 02234990 & $<.003$ & .005 & E.033 & $<.004$ & $<.002$ & .087 & $<.001$ & $<.02$ & $<.002$ & $<.004$ & $<.003$ & $<.003$ & $<.004$ \\
\hline 02234990 & $<.003$ & $<.004$ & E.007 & $<.004$ & $<.002$ & .033 & $<.001$ & $<.02$ & $<.002$ & $<.004$ & $<.003$ & $<.003$ & $<.004$ \\
\hline 02234990 & $<.020$ & $<.005$ & E.015 & $<.018$ & $<.003$ & .008 & $<.005$ & $<.02$ & $<.002$ & $<.009$ & $<.005$ & $<.003$ & $<.004$ \\
\hline 02263800 & $<.003$ & $<.004$ & E.078 & $<.004$ & $<.002$ & $<.002$ & $<.001$ & $<.02$ & $<.002$ & $<.004$ & $<.003$ & $<.003$ & $<.004$ \\
\hline 02263800 & $<.003$ & $<.004$ & E.009 & $<.004$ & $<.002$ & .004 & $<.001$ & $<.02$ & $<.002$ & $<.004$ & $<.003$ & $<.003$ & $<.004$ \\
\hline 02263800 & $<.020$ & $<.005$ & E.02 & $<.018$ & $<.003$ & $<.005$ & $<.005$ & $<.02$ & $<.002$ & $<.009$ & $<.005$ & $<.003$ & $<.004$ \\
\hline 02234635 & $<.003$ & $<.004$ & E.006 & $<.004$ & $<.002$ & $<.002$ & $<.001$ & $<.02$ & $<.002$ & $<.004$ & $<.003$ & $<.003$ & $<.004$ \\
\hline 02234635 & $<.003$ & $<.004$ & E.004 & $<.004$ & $<.002$ & $<.002$ & $<.001$ & $<.02$ & $<.002$ & $<.004$ & $<.003$ & $<.003$ & $<.004$ \\
\hline 02234635 & $<.020$ & $<.005$ & $<.006$ & $<.018$ & $<.003$ & $<.005$ & $<.005$ & $<.02$ & $<.002$ & $<.009$ & $<.005$ & $<.003$ & $<.004$ \\
\hline
\end{tabular}


[All concentrations dissolved; $\mu \mathrm{g} / \mathrm{L}$, micrograms per liter; $<$, less than; $E$, estimated concentration; $M$, presence verified, not quantified]

\begin{tabular}{|c|c|c|c|c|c|c|c|c|c|c|c|c|c|}
\hline Site identifier & $\begin{array}{c}\text { Linuron } \\
(\mu \mathrm{g} / \mathrm{L})\end{array}$ & $\begin{array}{l}\text { Malathion } \\
(\mu \mathrm{g} / \mathrm{L})\end{array}$ & $\begin{array}{l}\text { Azinphos- } \\
\text { Methyl } \\
(\mu \mathrm{g} / \mathrm{L})\end{array}$ & $\begin{array}{c}\text { Methyl } \\
\text { parathion } \\
(\mu \mathrm{g} / \mathrm{L})\end{array}$ & $\begin{array}{l}\text { Metolachlor } \\
(\mu \mathrm{g} / \mathrm{L})\end{array}$ & $\begin{array}{l}\text { Metribuzin } \\
\quad(\mu \mathrm{g} / \mathrm{L})\end{array}$ & $\begin{array}{c}\text { Molinate } \\
(\mu \mathrm{g} / \mathrm{L})\end{array}$ & $\begin{array}{l}\text { Napropa- } \\
\text { mide } \\
(\mu \mathrm{g} / \mathrm{L})\end{array}$ & $\begin{array}{c}\text { p,p' DDE } \\
(\mu \mathrm{g} / \mathrm{L})\end{array}$ & $\begin{array}{l}\text { Parathion } \\
(\mu \mathrm{g} / \mathrm{L})\end{array}$ & $\begin{array}{c}\text { Pebulate } \\
(\mu \mathrm{g} / \mathrm{L})\end{array}$ & $\begin{array}{c}\text { Pen- } \\
\text { dimethalin } \\
(\mu \mathrm{g} / L)\end{array}$ & $\begin{array}{c}\text { cis- } \\
\text { Perethrin } \\
(\mu \mathrm{g} / \mathrm{L})\end{array}$ \\
\hline \multicolumn{14}{|l|}{ Lakes } \\
\hline 02234205 & $<0.035$ & $<0.027$ & $<0.050$ & $<0.006$ & $<0.013$ & $<0.006$ & $<0.002$ & $<0.007$ & $<0.003$ & $<0.007$ & $<0.002$ & $<0.010$ & $<0.006$ \\
\hline 02234812 & $<.002$ & $<.005$ & $<.001$ & $<.006$ & $<.002$ & $<.004$ & $<.004$ & $<.003$ & $<.006$ & $<.004$ & $<.004$ & $<.004$ & $<.005$ \\
\hline 02234812 & $<.035$ & $<.027$ & $<.050$ & $<.006$ & $<.013$ & $<.006$ & $<.002$ & $<.007$ & $<.003$ & $<.007$ & $<.002$ & $<.010$ & $<.006$ \\
\hline 02234812 & $<.035$ & $<.027$ & $<.050$ & $<.006$ & $<.013$ & $<.006$ & $<.002$ & $<.007$ & $<.003$ & $<.007$ & $<.002$ & $<.010$ & $<.006$ \\
\hline 02262200 & $<.002$ & $<.005$ & $<.001$ & $<.006$ & $<.002$ & $<.004$ & $<.004$ & $<.003$ & $<.006$ & $<.004$ & $<.004$ & $<.004$ & $<.005$ \\
\hline 02262200 & $<.035$ & $<.027$ & $<.050$ & $<.006$ & $<.013$ & $<.006$ & $<.002$ & $<.007$ & $<.003$ & $<.007$ & $<.002$ & $<.010$ & $<.006$ \\
\hline 02262200 & $<.035$ & $<.027$ & $<.050$ & $<.006$ & E.002 & $<.006$ & $<.002$ & $<.007$ & $<.003$ & $<.007$ & $<.002$ & $<.010$ & $<.006$ \\
\hline 02266275 & $<.002$ & $<.005$ & $<.001$ & $<.006$ & $<.002$ & $<.004$ & $<.004$ & $<.003$ & $<.006$ & $<.004$ & $<.004$ & $<.004$ & $<.005$ \\
\hline 02266275 & $<.035$ & $<.027$ & $<.050$ & $<.006$ & E.001 & $<.006$ & $<.002$ & $<.007$ & $<.003$ & $<.007$ & $<.002$ & $<.010$ & $<.006$ \\
\hline 02234297 & $<.002$ & $<.005$ & $<.001$ & $<.006$ & $<.002$ & $<.004$ & $<.004$ & $<.003$ & $<.006$ & $<.004$ & $<.004$ & $<.004$ & $<.005$ \\
\hline 02234297 & $<.035$ & $<.027$ & $<.050$ & $<.006$ & $<.013$ & $<.006$ & $<.002$ & $<.007$ & $<.003$ & $<.007$ & $<.002$ & $<.010$ & $<.006$ \\
\hline 284000081275000 & $<.035$ & $<.027$ & $<.050$ & $<.006$ & $<.013$ & $<.006$ & $<.002$ & $<.007$ & $<.003$ & $<.007$ & $<.002$ & $<.010$ & $<.006$ \\
\hline 283528081055300 & $<.002$ & $<.005$ & $<.001$ & $<.006$ & $<.002$ & $<.004$ & $<.004$ & $<.003$ & $<.006$ & $<.004$ & $<.004$ & $<.004$ & $<.005$ \\
\hline 283528081055300 & $<.035$ & $<.027$ & $<.050$ & $<.006$ & $<.013$ & $<.006$ & $<.002$ & $<.007$ & $<.003$ & $<.007$ & $<.002$ & $<.010$ & $<.006$ \\
\hline 283528081055300 & $<.035$ & $<.027$ & $<.050$ & $<.006$ & $<.013$ & $<.006$ & $<.002$ & $<.007$ & $<.003$ & $<.007$ & $<.002$ & $<.010$ & $<.006$ \\
\hline 02237745 & $<.002$ & $<.005$ & $<.001$ & $<.006$ & E.003 & $<.004$ & $<.004$ & $<.003$ & $<.006$ & $<.004$ & $<.004$ & $<.004$ & $<.005$ \\
\hline 02237745 & $<.035$ & $<.027$ & $<.050$ & $<.006$ & E.001 & $<.006$ & $<.002$ & $<.007$ & $<.003$ & $<.007$ & $<.002$ & $<.010$ & $<.006$ \\
\hline 02237745 & $<.035$ & $<.027$ & $<.050$ & $<.006$ & E.004 & $<.006$ & $<.002$ & $<.007$ & $<.003$ & $<.007$ & $<.002$ & $<.010$ & $<.006$ \\
\hline 284034081315700 & $<.035$ & $<.027$ & $<.050$ & $<.006$ & $<.013$ & $<.006$ & $<.002$ & $<.007$ & $<.003$ & $<.007$ & $<.002$ & $<.010$ & $<.006$ \\
\hline 282927081235000 & $<.035$ & $<.027$ & $<.050$ & $<.006$ & $<.013$ & $<.006$ & $<.002$ & $<.007$ & $<.003$ & $<.007$ & $<.002$ & $<.010$ & $<.006$ \\
\hline 282657080561900 & $<.035$ & $<.027$ & $<.050$ & $<.006$ & $<.013$ & $<.006$ & $<.002$ & $<.007$ & $<.003$ & $<.007$ & $<.002$ & $<.010$ & $<.006$ \\
\hline 282657080561900 & $<.035$ & $<.027$ & $<.050$ & $<.006$ & $<.013$ & $<.006$ & $<.002$ & $<.007$ & $<.003$ & $<.007$ & $<.002$ & $<.010$ & $<.006$ \\
\hline 282102081374600 & $<.035$ & $<.027$ & $<.050$ & $<.006$ & E.001 & $<.006$ & $<.002$ & $<.007$ & $<.003$ & $<.007$ & $<.002$ & E.008 & $<.006$ \\
\hline 283019081283100 & $<.002$ & $<.005$ & $<.001$ & $<.006$ & E.004 & $<.004$ & $<.004$ & $<.003$ & $<.006$ & $<.004$ & $<.004$ & $<.004$ & $<.005$ \\
\hline 283019081283100 & $<.035$ & $<.027$ & $<.050$ & $<.006$ & $<.013$ & $<.006$ & $<.002$ & $<.007$ & $<.003$ & $<.007$ & $<.002$ & $<.010$ & $<.006$ \\
\hline 283019081283100 & $<.035$ & $<.027$ & $<.050$ & $<.006$ & E.001 & $<.006$ & $<.002$ & $<.007$ & $<.003$ & $<.007$ & $<.002$ & $<.010$ & $<.006$ \\
\hline \multicolumn{14}{|l|}{ Streams } \\
\hline 02262900 & $<.002$ & $<.005$ & $<.001$ & $<.006$ & $<.002$ & $<.004$ & $<.004$ & $<.003$ & $<.006$ & $<.004$ & $<.004$ & $<.004$ & $<.005$ \\
\hline 02262900 & $<.002$ & $<.005$ & $<.001$ & $<.006$ & $<.002$ & $<.004$ & $<.004$ & $<.003$ & $<.006$ & $<.004$ & $<.004$ & $<.004$ & $<.005$ \\
\hline 02262900 & $<.035$ & $<.027$ & $<.050$ & $<.006$ & $<.013$ & $<.006$ & $<.002$ & $<.007$ & $<.003$ & $<.007$ & $<.002$ & $<.010$ & $<.006$ \\
\hline 02233500 & $<.002$ & $<.005$ & $<.001$ & $<.006$ & $<.005$ & $<.004$ & $<.004$ & $<.003$ & $<.006$ & $<.004$ & $<.004$ & $<.004$ & $<.005$ \\
\hline 02233500 & $<.002$ & $<.005$ & $<.001$ & $<.006$ & $<.002$ & $<.004$ & $<.004$ & $<.003$ & $<.006$ & $<.004$ & $<.004$ & $<.004$ & $<.005$ \\
\hline 02233500 & $<.035$ & $<.027$ & $<.050$ & $<.006$ & $<.013$ & $<.006$ & $<.002$ & $<.007$ & $<.003$ & $<.007$ & $<.002$ & $<.010$ & $<.006$ \\
\hline 02233200 & $<.002$ & .025 & $<.001$ & $<.006$ & $<.002$ & $<.004$ & $<.004$ & $<.003$ & $<.006$ & $<.004$ & $<.004$ & $<.004$ & $<.005$ \\
\hline 02233200 & $<.002$ & $<.005$ & $<.001$ & $<.006$ & E.002 & $<.004$ & $<.004$ & $<.003$ & $<.006$ & $<.004$ & $<.004$ & $<.004$ & $<.005$ \\
\hline 02233200 & $<.035$ & $<.027$ & $<.050$ & $<.006$ & $<.013$ & $<.006$ & $<.002$ & $<.007$ & $<.003$ & $<.007$ & $<.002$ & $<.010$ & $<.006$ \\
\hline 02234990 & $<.002$ & $<.005$ & $<.001$ & $<.006$ & $<.002$ & $<.004$ & $<.004$ & $<.003$ & $<.006$ & $<.004$ & $<.004$ & $<.004$ & $<.005$ \\
\hline 02234990 & $<.002$ & $<.005$ & $<.001$ & $<.006$ & $<.002$ & $<.004$ & $<.004$ & $<.003$ & $<.006$ & $<.004$ & $<.004$ & $<.004$ & $<.005$ \\
\hline 02234990 & $<.035$ & $<.027$ & $<.050$ & $<.006$ & $<.013$ & $<.006$ & $<.002$ & $<.007$ & $<.003$ & $<.007$ & $<.002$ & $<.010$ & $<.006$ \\
\hline 02263800 & $<.002$ & $<.005$ & $<.001$ & $<.006$ & .009 & $<.004$ & $<.004$ & $<.050$ & $<.006$ & $<.004$ & $<.004$ & $<.004$ & $<.005$ \\
\hline 02263800 & $<.002$ & $<.005$ & $<.001$ & $<.006$ & $<.002$ & $<.004$ & $<.004$ & $<.003$ & $<.006$ & $<.004$ & $<.004$ & $<.004$ & $<.005$ \\
\hline 02263800 & $<.035$ & $<.027$ & $<.050$ & $<.006$ & $<.013$ & $<.006$ & $<.002$ & $<.007$ & $<.003$ & $<.007$ & $<.002$ & $<.010$ & $<.006$ \\
\hline 02234635 & $<.002$ & $<.005$ & $<.001$ & $<.006$ & $<.002$ & $<.004$ & $<.004$ & $<.003$ & $<.006$ & $<.004$ & $<.004$ & $<.004$ & $<.005$ \\
\hline 02234635 & $<.002$ & $<.005$ & $<.001$ & $<.006$ & $<.002$ & $<.004$ & $<.004$ & $<.003$ & $<.006$ & $<.004$ & $<.004$ & .004 & $<.005$ \\
\hline 02234635 & $<.035$ & $<.027$ & $<.050$ & $<.006$ & $<.013$ & $<.006$ & $<.002$ & $<.007$ & $<.003$ & $<.007$ & $<.002$ & $<.010$ & $<.006$ \\
\hline
\end{tabular}


Appendix E. Concentrations of pesticides in samples collected from lakes and streams during this study, 2000-2001.

[All concentrations dissolved; $\mu \mathrm{g} / \mathrm{L}$, micrograms per liter; <, less than; $\mathrm{E}$, estimated concentration; $M$, presence verified, not quantified]

\begin{tabular}{|c|c|c|c|c|c|c|c|c|c|c|c|c|c|}
\hline Site identifier & $\begin{array}{c}\text { Phorate } \\
(\mu \mathrm{g} / \mathrm{L})\end{array}$ & $\begin{array}{l}\text { Prometon } \\
(\mu \mathrm{g} / \mathrm{L})\end{array}$ & $\begin{array}{l}\text { Pronamide } \\
(\mu \mathrm{g} / \mathrm{L})\end{array}$ & $\begin{array}{l}\text { Propachlor } \\
(\mu \mathrm{g} / \mathrm{L})\end{array}$ & $\begin{array}{l}\text { Propanil } \\
(\mu \mathrm{g} / \mathrm{L})\end{array}$ & $\begin{array}{l}\text { Propargite } \\
(\mu \mathrm{g} / \mathrm{L})\end{array}$ & $\begin{array}{c}\text { Simazine } \\
(\mu \mathrm{g} / \mathrm{L})\end{array}$ & $\begin{array}{l}\text { Tebuthiuron } \\
(\mu \mathrm{g} / \mathrm{L})\end{array}$ & $\begin{array}{c}\text { Terbacil } \\
(\mu \mathrm{g} / \mathrm{L})\end{array}$ & $\begin{array}{c}\text { Terbufos } \\
(\mu \mathrm{g} / \mathrm{L})\end{array}$ & $\begin{array}{c}\text { Thiobencarb } \\
(\mu \mathrm{g} / \mathrm{L})\end{array}$ & $\begin{array}{c}\text { Triallate } \\
(\mu \mathbf{g} / L)\end{array}$ & $\begin{array}{l}\text { Trifluralin } \\
(\mu \mathrm{g} / L)\end{array}$ \\
\hline \multicolumn{14}{|l|}{ Lakes } \\
\hline 02234205 & $<.011$ & E.01 & $<.004$ & $<.010$ & $<.011$ & $<.02$ & E.005 & E.01 & $<.034$ & $<.02$ & $<.005$ & $<.002$ & $<.009$ \\
\hline 02234812 & $<.002$ & .04 & $<.003$ & $<.007$ & $<.004$ & $<.01$ & $<.005$ & E.02 & $<.007$ & $<.01$ & $<.002$ & $<.001$ & $<.002$ \\
\hline 02234812 & $<.011$ & .02 & $<.004$ & $<.010$ & $<.011$ & $<.02$ & $<.011$ & E.01 & $<.034$ & $<.02$ & $<.005$ & $<.002$ & $<.009$ \\
\hline 02234812 & $<.011$ & .03 & $<.004$ & $<.010$ & $<.011$ & $<.02$ & $<.011$ & E.01 & $<.034$ & $<.02$ & $<.005$ & $<.002$ & $<.009$ \\
\hline 02262200 & $<.002$ & $<.02$ & $<.003$ & $<.007$ & $<.004$ & $<.01$ & $<.005$ & $<.01$ & $<.007$ & $<.01$ & $<.002$ & $<.001$ & $<.002$ \\
\hline 02262200 & $<.011$ & M & $<.004$ & $<.010$ & $<.011$ & $<.02$ & E.003 & $<.02$ & $<.034$ & $<.02$ & $<.005$ & $<.002$ & $<.009$ \\
\hline 02262200 & $<.011$ & M & $<.004$ & $<.010$ & $<.011$ & $<.02$ & $<.011$ & $<.02$ & $<.034$ & $<.02$ & $<.005$ & $<.002$ & $<.009$ \\
\hline 02266275 & $<.002$ & $<.02$ & $<.003$ & $<.007$ & $<.004$ & $<.01$ & E.004 & $<.01$ & $<.007$ & $<.01$ & $<.002$ & $<.001$ & $<.002$ \\
\hline 02266275 & $<.011$ & $<.01$ & $<.004$ & $<.010$ & $<.011$ & $<.02$ & E.003 & $<.02$ & $<.034$ & $<.02$ & $<.005$ & $<.002$ & $<.009$ \\
\hline 02234297 & $<.002$ & E.01 & $<.003$ & $<.007$ & $<.004$ & $<.01$ & $<.005$ & $<.01$ & $<.007$ & $<.01$ & $<.002$ & $<.001$ & $<.002$ \\
\hline 02234297 & $<.011$ & E.01 & $<.004$ & $<.010$ & $<.011$ & $<.02$ & $<.011$ & E.01 & $<.034$ & $<.02$ & $<.005$ & $<.002$ & $<.009$ \\
\hline 284000081275000 & $<.011$ & $<.01$ & $<.004$ & $<.010$ & $<.011$ & $<.02$ & $<.011$ & $<.02$ & $<.034$ & $<.02$ & $<.005$ & $<.002$ & $<.009$ \\
\hline 283528081055300 & $<.002$ & $<.02$ & $<.003$ & $<.007$ & $<.004$ & $<.01$ & .012 & $<.01$ & $<.007$ & $<.01$ & $<.002$ & $<.001$ & $<.002$ \\
\hline 283528081055300 & $<.011$ & $<.01$ & $<.004$ & $<.010$ & $<.011$ & $<.02$ & E.006 & $<.02$ & $<.034$ & $<.02$ & $<.005$ & $<.002$ & $<.009$ \\
\hline 283528081055300 & $<.011$ & $<.01$ & $<.004$ & $<.010$ & $<.011$ & $<.02$ & $<.011$ & $<.02$ & $<.034$ & $<.02$ & $<.005$ & $<.002$ & $<.009$ \\
\hline 02237745 & $<.002$ & E.01 & $<.003$ & $<.007$ & $<.004$ & $<.01$ & E.002 & $<.01$ & $<.007$ & $<.01$ & $<.002$ & $<.001$ & $<.002$ \\
\hline 02237745 & $<.011$ & E.01 & $<.004$ & $<.010$ & $<.011$ & $<.02$ & $<.011$ & $<.02$ & $<.034$ & $<.02$ & $<.005$ & $<.002$ & $<.009$ \\
\hline 02237745 & $<.011$ & E.01 & $<.004$ & $<.010$ & $<.011$ & $<.02$ & $<.011$ & $<.02$ & $<.034$ & $<.02$ & $<.005$ & $<.002$ & $<.009$ \\
\hline 284034081315700 & $<.011$ & E.01 & $<.004$ & $<.010$ & $<.011$ & $<.02$ & $<.011$ & E.01 & $<.034$ & $<.02$ & $<.005$ & $<.002$ & $<.009$ \\
\hline 282927081235000 & $<.011$ & E.01 & $<.004$ & $<.010$ & $<.011$ & $<.02$ & E.005 & E.01 & $<.034$ & $<.02$ & $<.005$ & $<.002$ & $<.009$ \\
\hline 282657080561900 & $<.011$ & $<.01$ & $<.004$ & $<.010$ & $<.011$ & $<.02$ & $<.011$ & $<.02$ & $<.034$ & $<.02$ & $<.005$ & $<.002$ & $<.009$ \\
\hline 282657080561900 & $<.011$ & $<.01$ & $<.004$ & $<.010$ & $<.011$ & $<.02$ & $<.011$ & $<.02$ & $<.034$ & $<.02$ & $<.005$ & $<.002$ & $<.009$ \\
\hline 282102081374600 & $<.011$ & E.01 & $<.004$ & $<.010$ & $<.011$ & $<.02$ & $<.011$ & $<.02$ & $<.034$ & $<.02$ & $<.005$ & $<.002$ & $<.009$ \\
\hline 283019081283100 & $<.002$ & E.01 & $<.003$ & $<.007$ & $<.004$ & $<.01$ & $<.005$ & $<.01$ & $<.007$ & $<.01$ & $<.002$ & $<.001$ & $<.002$ \\
\hline 283019081283100 & $<.011$ & E.01 & $<.004$ & $<.010$ & $<.011$ & $<.02$ & $<.011$ & $<.02$ & $<.034$ & $<.02$ & $<.005$ & $<.002$ & $<.009$ \\
\hline 283019081283100 & $<.011$ & $\mathrm{M}$ & $<.004$ & $<.010$ & $<.011$ & $<.02$ & $<.011$ & $<.02$ & $<.034$ & $<.02$ & $<.005$ & $<.002$ & $<.009$ \\
\hline \multicolumn{14}{|l|}{ Streams } \\
\hline 02262900 & $<.002$ & E.01 & $<.003$ & $<.007$ & $<.004$ & $<.01$ & $<.005$ & .02 & $<.007$ & $<.01$ & $<.002$ & $<.001$ & $<.002$ \\
\hline 02262900 & $<.002$ & E.01 & $<.003$ & $<.007$ & $<.004$ & $<.01$ & $<.005$ & E.01 & $<.007$ & $<.01$ & $<.002$ & $<.001$ & $<.002$ \\
\hline 02262900 & $<.011$ & E.01 & $<.004$ & $<.010$ & $<.011$ & $<.02$ & $<.011$ & E.01 & $<.034$ & $<.02$ & $<.005$ & $<.002$ & $<.009$ \\
\hline 02233500 & $<.002$ & E.01 & $<.003$ & $<.007$ & $<.004$ & $<.01$ & .009 & E.01 & $<.007$ & $<.01$ & $<.002$ & $<.001$ & $<.002$ \\
\hline 02233500 & $<.002$ & E.01 & $<.003$ & $<.007$ & $<.004$ & $<.01$ & $<.005$ & .01 & $<.040$ & $<.01$ & $<.002$ & $<.001$ & $<.002$ \\
\hline 02233500 & $<.011$ & $<.01$ & $<.004$ & $<.010$ & $<.011$ & $<.02$ & $<.011$ & $<.02$ & $<.034$ & $<.02$ & $<.005$ & $<.002$ & $<.009$ \\
\hline 02233200 & $<.002$ & $\mathrm{M}$ & $<.003$ & $<.007$ & $<.004$ & $<.01$ & $<.005$ & $<.01$ & $<.007$ & $<.01$ & $<.002$ & $<.001$ & $<.002$ \\
\hline 02233200 & $<.002$ & E.01 & $<.008$ & $<.007$ & $<.004$ & $<.01$ & E.004 & $\mathrm{M}$ & $<.007$ & $<.01$ & $<.002$ & $<.001$ & $<.002$ \\
\hline 02233200 & $<.011$ & E.01 & $<.004$ & $<.010$ & $<.011$ & $<.02$ & .016 & $\mathrm{M}$ & $<.034$ & $<.02$ & $<.005$ & $<.002$ & $<.009$ \\
\hline 02234990 & $<.002$ & E.01 & $<.003$ & $<.007$ & $<.004$ & $<.01$ & E.004 & .02 & $<.007$ & $<.01$ & $<.002$ & $<.001$ & $<.002$ \\
\hline 02234990 & $<.002$ & E.01 & $<.003$ & $<.007$ & $<.004$ & $<.01$ & .008 & $<.01$ & $<.007$ & $<.01$ & $<.002$ & $<.001$ & $<.002$ \\
\hline 02234990 & $<.011$ & E.01 & E.001 & $<.010$ & $<.011$ & $<.02$ & E.005 & E.01 & $<.034$ & $<.02$ & $<.005$ & $<.002$ & $<.009$ \\
\hline 02263800 & $<.002$ & E.01 & $<.003$ & $<.007$ & $<.004$ & $<.01$ & .005 & .01 & $<.007$ & $<.01$ & $<.002$ & $<.001$ & $<.002$ \\
\hline 02263800 & $<.002$ & E.01 & $<.003$ & $<.007$ & $<.004$ & $<.01$ & $<.005$ & $<.01$ & $<.007$ & $<.01$ & $<.002$ & $<.001$ & $<.002$ \\
\hline 02263800 & $<.011$ & E.01 & $<.004$ & $<.010$ & $<.011$ & $<.02$ & $<.011$ & $<.02$ & $<.034$ & $<.02$ & $<.005$ & $<.002$ & $<.009$ \\
\hline 02234635 & $<.002$ & E.01 & $<.003$ & $<.007$ & $<.004$ & $<.01$ & .006 & $<.01$ & $<.007$ & $<.01$ & $<.002$ & $<.001$ & $<.002$ \\
\hline 02234635 & $<.002$ & M & $<.003$ & $<.007$ & $<.004$ & $<.01$ & $<.005$ & $<.01$ & $<.007$ & $<.01$ & $<.002$ & $<.001$ & E.003 \\
\hline 02234635 & $<.011$ & $<.01$ & $<.004$ & $<.010$ & $<.011$ & $<.02$ & $<.011$ & $<.02$ & $<.034$ & $<.02$ & $<.005$ & $<.002$ & $<.009$ \\
\hline
\end{tabular}

